\title{
REVISION OF THE NEOTROPICAL GENERA BOCAGEOPSIS, ONYCHOPETALUM, AND UNONOPSIS (ANNONACEAE)
}

\author{
PAUL J.M. MAAS, LUBBERT Y.TH. WESTRA \& MARLOES VERMEER \\ Nationaal Herbarium Nederland, Utrecht University branch, \\ W.C. van Unnikgebouw, Heidelberglaan 2, 3584 CS Utrecht, The Netherlands
}

\begin{abstract}
SUMMARY
A taxonomic revision is made of the Neotropical genera Bocageopsis, Onychopetalum, and Unonopsis (Annonaceae). The closeness of these three genera was expressed by Fries when he placed them in his (informal) Unonopsis group (Fries, 1959), and the close relationship is supported by more recent phylogenetic research as well. Four species are recognized in Bocageopsis and two species in Onychopetalum. Unonopsis is by far the largest of the three genera with close to 50 species, of which no less than 23 species are here described as new. One species (Unonopsis umbilicata) had to be shelved as insufficiently known for lack of data, and another, obviously new, species from Colombia is too incomplete and is described provisionally as Unonopsis spec. A.

Several keys are provided, one for the genera and one each for the species of Bocageopsis and Onychopetalum. For the species of Unonopsis a key to all species and, in addition, a key to the species of Mexico and Central America are provided. The species treatments include full descriptions, geographical and ecological notes, distribution maps, synonymy, taxonomic notes, and vernacular names. A complete list of exsiccatae is appended.

Parallel to the taxonomic revision, a leaf anatomical survey was made by E.-J. van Marle, and is included here.
\end{abstract}

Key words: Annonaceae, Bocageopsis, Onychopetalum, Unonopsis, leaf anatomy, taxonomy.

\section{INTRODUCTION}

The Neotropical genus Unonopsis was first published by Robert E. Fries in 1900. The two allied genera Bocageopsis and Onychopetalum, also from the Neotropics, were published later (Fries, 1931). Some years thereafter a revision of all three genera followed (Fries, 1937).

In the large survey of the whole family (Fries, 1959) the three genera were placed in the 'Unonopsis-Gruppe', an informal group including the three Neotropical genera along with five genera from Africa (Dennettia, Dielsiothamnus, Polyceratocarpus, Uvariastrum, and Uvariodendron) and one from Asia (Neouvaria). Diagnostic features of the Unonopsis group are axillary inflorescences, the presence of bracts, articulate pedicels, valvate sepals, petals in two trimerous whorls, valvate, the outer petals not entirely touching toward the base and leaving a part of the inner petals uncovered, the uncovered median part of the inner petals raised and covered by hairs, carpels with laterally attached ovules in varying number, fruit apocarpous, and monocarps most often shortly stipitate. 
In his key Fries distinguished Bocageopsis and Onychopetalum from Unonopsis by a staminal character, Unonopsis having the connective prolonged into an apical, discoid shield, vs Bocageopsis and Onychopetalum having a tongue-like, long-acute connective shield. He differentiated Onychopetalum from Bocageopsis by the petals provided with an incurved apical appendage and the presence of 3 or 4 ovules per carpel. Bocageopsis lacks an incurved apical appendage on the petals and has only 2 ovules per carpel.

In his 1937 revision of the genus Unonopsis, Fries distinguished 22 species, but by the time of his survey of the whole family (1959) the number had increased to 27 species. After 1959 the genus did not undergo any further revisional work, though a few more new species were added: Unonopsis storkii Standl. \& L.O. Williams (Williams, 1963), $U$. aviceps Maas and $U$ velutina Maas (Maas et al., 1986), U. macrocarpa Maas \& Setten (Maas et al., 1988), and U. theobromifolia N. Zamora \& Poveda (1988).

The present monographic study of Unonopsis was started in 1999 by Camilla Orava, then an MSc student from Helsinki, Finland, working in Utrecht under the supervision of P.J.M. Maas. Due to private circumstances Ms. Orava had to abandon her monographic work in 2001, after which the task of revising the genus fell to Maas and Westra.

In our revision of Unonopsis 47 species are recognized, 25 of which are new or of very recent date (see $U$. bauxitae Maas, Westra \& Mello-Silva). Almost half of the 27 species distinguished by Fries in 1959 are now put into synonymy. This also applies to $U$. velutina just mentioned (currently synonymized with $U$. spectabilis Diels). Yet, as compared to Fries's 1937 revision, the number of species in Unonopsis has more than doubled.

In Bocageopsis Fries $(1937,1959)$ distinguished three species, all transferred from Bocagea. A fourth species, B. pleiosperma Maas, was described more recently (Maas et al., 1986). All four species are accepted in the present treatment.

Onychopetalum initially was published with the sole species $O$. amazonicum R.E. Fr. In his 1937 paper Fries added three more species. Later on, Johnson \& Murray (1995) transferred Trigynaea periquino Rusby to Onychopetalum, at the same time putting $O$. krukoffii R.E. Fr. into synonymy with $O$. periquino (Rusby) D. M. Johnson $\&$ N.A. Murray. In the present treatment only two species are recognized, namely: $O$. amazonicum R.E. Fr. (incl. O. lanceolatum R.E. Fr.) and $O$. periquino (now also including O. lucidum R.E. Fr.). Both Bocageopsis and Onychopetalum were revised by Marloes Vermeer, at that time a Utrecht undergraduate student, and the third author of the present paper.

Various classificatory studies on the position of genera in the Annonaceae, using different characters, have been published.

1) Walker (1971), in his survey of pollen characters in Annonaceae, distinguished a Malmea subfamily and within that the Malmea tribe. In that tribe he included 10 Neotropical genera, viz. Bocageopsis, Cremastosperma, Ephedranthus, Malmea s.1., Onychopetalum, Oxandra, Pseudephedranthus, Pseudoxandra, Ruizodendron, and Unonopsis, and the African genus Annickia (Enantia Oliv., non Falc. [Sabiaceae]).

2) In 1986 Van Setten \& Koek-Noorman performed a research on leaf anatomical characters in Annonaceae. According to them the genera of the Unonopsis group 
sensu Fries (1959) all had in common the complex structure of the primary vein, the presence of silica bodies, and idioblastic (oil) cells in the epidermis.

3) In Van Heusden's (1992) survey of floral characters in Annonaceae a Unonopsis group is distinguished including only the three genera Bocageopsis, Onychopetalum, and Unonopsis, characterized by valvate sepals and petals (mostly white and small), simple hairs, and with 1-6, mostly lateral ovules. Van Heusden noticed some general resemblance to the flowers of her Cremastosperma group which, however, have imbricate sepals and petals, and only 1 ovule. (Van Heusden also reported rarely imbricate sepals in Onychopetalum, and slightly imbricate petals in Bocageopsis and Onychopetalum, beside the standard valvate condition. The present authors could not confirm this.)

4) Van Setten \& Koek-Noorman (1992), in their study of fruits and seeds of almost all genera within the family, included the 3 genera under revision and the African genus Annickia in their group 7, defined by a distinct, canaliculate raphe (a character found outside this group only in one species of Diclinanona, and in Mosannona xanthochlora), and by few, laterally placed, pitted seeds with spiniform ruminations. However, similarly pitted seeds with spiniform ruminations are also found in some other groups.

5) Doyle et al. (2000) performed a combined analysis of pollen morphological and molecular $(r b c \mathrm{~L})$ data. They placed Unonopsis in the Malmeoid clade together with the Neotropical genera Ephedranthus and Malmea, the African genus Annickia, and an Asian species of Polyalthia (P. sumatrana). Bocageopsis and Onychopetalum were not among the genera investigated.

6) Richardson et al. (2004), in a study on historical biogeography of the cosmopolitan families Annonaceae and Rhamnaceae, carried out phylogenetic analyses based on $r b c \mathrm{~L}$ and $t r n \mathrm{~L}-\mathrm{F}$ plastid DNA sequences. Bocageopsis, Onychopetalum, and Unonopsis are placed as a strongly supported clade in the so-called Short Branch Clade. This is confirmed shortly thereafter in a study by Pirie et al. (2006) on the basis of more plastid sequence data. The relation between the Unonopsis group and other groups remains to be investigated.

Recently Botermans (2006, unpublished) performed a phylogenetic analysis of the genera Bocageopsis, Onychopetalum, and Unonopsis based on plastid and nuclear sequence data. She concluded that the Unonopsis group as already recognized by earlier taxonomists is a monophyletic one. Unonopsis according to her is a monophyletic genus, too. Bocageopsis and Onychopetalum proved to be difficult to distinguish due to a lack of sufficient informative characters.

\section{MATERIAL AND METHODS}

Herbarium material was investigated from the following herbaria: A, AAU, B, BM, BR, BRG, BRIT, C, CAY, CEPEC, COL, CR, CVRD, DUKE, E, EAP, ECON, F, G, GB, GH, HBG, HUA, IAN, INB, INPA, JAUM, K, L, LA, LE, LPB, M, MBML, MEXU, MG, MICH, MO, MY, NA, NY, OXF, P, PMA, PORT, QCA, QCNE, RB, S, SCZ, SP, SPF, U, UC, US, VEN, W, WAG, WIS, WU, Z.

For terms relating to shape we used the terminology recommended and/or used by the Systematics Association Committee for descriptive terminology (1962). Descriptive 
terms for leaf venation are after Hickey (1979). To describe density of indument we distinguished four categories: 1) densely covered: hairs very numerous and hiding the epidermis from view or almost so; 2) rather densely covered: hairs numerous, touching each other or not, the epidermis well visible; 3 ) sparsely covered: hairs widely spaced, c. $10 / \mathrm{mm}^{2}$ or less; and 4) glabrous.

Measurements as a rule were made from dried material. Measurements on material preserved in spirit are given between accolades \{\} .

Colour indications and descriptions of surface structures are based on dried material, unless stated otherwise.

\section{INFLORESCENCE STRUCTURE IN BOCAGEOPSIS, ONYCHOPETALUM, AND UNONOPSIS}

Inflorescences in Annonaceae are of the determinate type (also termed monotelic or anthotelic), with the axis always ending in a terminal flower (see also, among others, Fries, 1959: 13 et seq.; Briggs \& Johnson, 1979: 175 et seq.; Weberling, 1981, 1989; Weberling \& Hoppe, 1996; Maas et al., 2003: 8-11). Apart from (few) exceptions, inflorescences (sometimes reduced to a single flower) appear as lateral structures to the observer, rather than terminal. In the majority of genera this is due to overtopping by a lateral shoot originating from the axil of a leaf immediately below the floral region, which continues to grow in the direction of the main shoot, pushing the terminal flower/inflorescence to the side so that this becomes pseudolateral (often opposed to a leaf). Good examples are, among others, the genera Rollinia and Duguetia which were recently revised by Maas and co-workers (Maas et al., 1992, 2003). In the second largest group of genera inflorescences are developed generally at the ends of axillary shoots. These lateral shoots are mostly short shoots (brachyblasts), and in extreme cases may be reduced to a single inflorescence or flower. The habit is that of a plant with axillary flowers or (mostly small) axillary inflorescences.

The three closely related genera Bocageopsis, Onychopetalum, and Unonopsis belong to the latter category. The inflorescence structures in these genera are essentially similar. A figure by Fries (1919: 41, f. 34; Weberling \& Hoppe, 1996: f. 2 IX) may serve for a better understanding. In this example we see a much reduced axillary shoot provided at or near the base with the single prophyll facing the main (vegetative) axis, i.e. the adaxial (addorsed) prophyll characteristic for Annonaceae. Next come two bracts followed by the terminal flower. This part, as seen from the attachment of the prophyll upward, conforms to the bibracteate pedicel found in many members of the family (for an overview of pedicel types in Annonaceae see Fries, 1959: 34). From the axil of the lower pedicel bract a flower on a similar bibracteate pedicel develops: the lower bract of this second order pedicel is at the same time the prophyll of that pedicel. As this prophyll has the potential to develop an axillary bud in turn, a third order pedicel might eventually result. Next order axillary buds can, in principle, continue to develop without end. We can now discern a reiteration pattern, leading to the cymosely branched partial inflorescence type known as the rhipidium (Eichler, 1875: 39, f. 19A; Weberling, 1981: 225, 'Fächel' in German; Weberling, 1989: 212). Summarizing, Fries's figure shows what in our descriptions hereafter will be referred to as an axillary inflorescence with one rhipidium. If no flower should develop from the axil of the lower bract of the primary 
flower, a single axillary flower remains (e.g., Unonopsis bullata, U. costaricensis, U. elegantissima, U. panamensis, $U$. penduliflora, $U$. peruviana). Conversely, the main axis might develop a number of nodes beyond the prophyll before the terminal flower is formed. Corresponding with the larger number of nodes, more bracts will be formed, and from the axil of each bract a lateral flower or rhipidium might originate. This type of inflorescence has been termed a thyrsoid (Briggs \& Johnson, 1979: 177): a plurinodate (or multinodate) main axis with determinate lateral branches and ending in a terminal flower (Weberling \& Hoppe, 1996: 30 et seq.). Often the lower lateral branches do not consist of a single rhipidium, but are themselves thyrsoidal: the whole inflorescence then becomes a double thyrsoid (diplothyrsoid).

Fig. 1 gives a descriptive scheme for inflorescences in this paper. The figure represents a diplothyrsoid as drawn from Gudiño \& Andi 2056 (U.floribunda, MO). Dotted parts indicate the zone of indeterminate growth, i.e. the main axis and axes of 2 nd order. Blank indicates zones of determinate growth, i.e. rhipidia. Arrows indicate scars of fallen flowers, the double arrows mark the scar of the terminal flower of the main axis which at the same time is the first flower of the terminal rhipidium. In the descriptions, internodes within the zone of indeterminate growth are referred to as axial internodes. Often axial internodes are extremely short $(\leq 1 \mathrm{~mm})$, giving inflorescences a compact appearance. If axial internodes are $>1 \mathrm{~mm}$ long (all or in part), the inflorescences become more lax, and are described as sublax or lax, or panicle-like (etc.) (Plate 4b). Note that compact or lax inflorescences still might show a single flower or fruit, whether by reduction or by dropping of flowers that failed to set fruit. It is therefore important to look not only at a flower or fruit, but also at nodes below the pedicel, particularly when using the keys. Often inflorescences, especially older ones, appear as if stalked. This 'stalk' is no true peduncle, but for convenience's sake is mentioned as peduncle-like base in descriptions whenever needed. It is usually the result of consecutive (short) internodes becoming indistinct in age (as if fusing), after loss of bracts and possibly shedding of lateral branches. In some species also a single, relatively long internode might resemble a peduncle. Another aspect to be mentioned is occurrence of inflorescences in pairs (or even in three's or more). This occurs in U.floribunda, U. rufescens (Plate 2b), and in various other species (even though not explicitly mentioned in all descriptions). A likely explanation is sprouting from axils of bracts very close to the base: what looks like two or more clustered inflorescences actually still is a single inflorescence. However, sprouting from accessory buds should perhaps not always be ruled out (see e.g. Cananga odorata as demonstrated by Weberling \& Hoppe, 1996: f. 6). Accessory buds no doubt account for vegetative shoots arising sometimes on the axonoscopic side of inflorescences in various species. Compare this with an example in Xylopia (Fries, 1919: 39; 1959: 15; Weberling \& Hoppe, 1996: f. 2 VII, VIII).

The number of flowers on a rhipidium seen at one time generally varies between 2 and 3 (this includes developmental stages from young bud to flower-past-anthesis). This applies to all three genera treated here. Single-flowered forms can then be understood as extreme reductions. On the other hand, most rhipidia produce more than three flowers during their lifespan. The total number of consecutive flowers produced by one rhipidium can vary between species, and also within the same species. In rhipidia with $>3$ consecutive flowers the persistent basal parts of dropped pedicels form a sympodial rachis. The length and shape of a sympodial rachis will vary along with the number of 


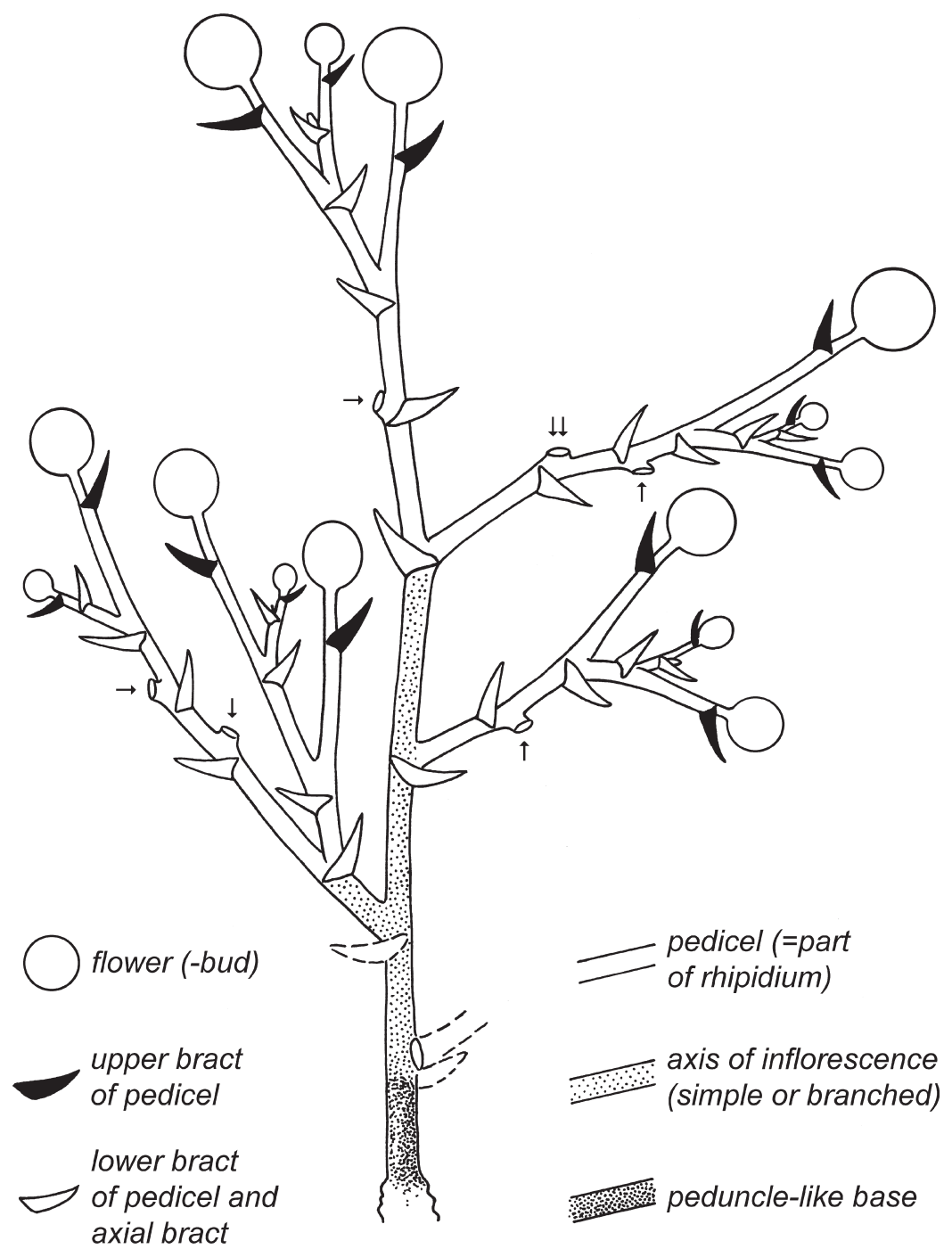

Fig. 1. Descriptive scheme for a branched inflorescence type as found in Bocageopsis, Onychopetalum, and Unonosis. Represented here is U. floribunda (Gudiño \& Andi 2056, MO). See further discussion in text. - Drawing by H. Rypkema.

flowers produced so far, but also with pedicel characteristics. The 'standard' pedicel type, which is the one most commonly found in the three genera, has the lower bract = prophyll at or very close to the base. The articulation is immediately above the lower bract, while the upper bract is attached somewhere between articulation and the flower (varying between and/or within species). Prolonged flower production will result in a compact-looking sympodial rachis with closely fitting pedicel scars. If there is some more distance between the lower pedicel bract and the pedicel base (a supra-basal 
lower bract) a sympodial rachis can become longer accordingly, the pedicel scars now separated by internode-like parts. Compare also inflorescences in Malmea (Chatrou, 1998: Ch. 6, f. 1) and flagelliform inflorescences in Duguetia (Maas et al., 2003: 8-11). Although not truly internodes, we refer to them as internodes in our descriptions of a sympodial rachis for the sake of convenience (see, e.g., U.floribunda, U. glaucopetala, $U$. pacifica, $U$. pittieri). Rather rarely the articulation is situated at some distance above the lower bract, instead of immediately above it in at least part of the pedicels. After shedding of a flower the pedicel part between lower bract and articulation will remain as a loose end sticking out from the sympodial rachis. Such free pedicel remnants were observed in specimens of $U$. pittieri, U. spectabilis, and $U$. stipitata. Further occurrence in other material is perhaps not to be ruled out altogether.

\section{LEAF ANATOMY OF BOCAGEOPSIS, ONYCHOPETALUM, AND UNONOPSIS}

Erik-J. van Marle

Nationaal Herbarium Nederland, Utrecht University branch

\section{MATERIAL AND METHODS}

The collections studied are cited in Table 1. From these herbarium collections, samples were taken from mature leaves at 1/3 of the lamina length, as seen from the base. The removed leaf parts were rehydrated by boiling in water and were used for the preparation of transverse sections of the central part of the lamina including the primary vein, as well as cuticular macerations. All sections were bleached and stained with Astra-blue and Safranin. Cuticular macerations were put in equal volumes of acetic acid $100 \%$ and hydrogen acid $30 \%$ at $60^{\circ} \mathrm{C}$ for several days, and stained with Sudan IV.

The slides were examined using a Leitz Dialux microscope. Photography was done with a Nikon Coolpix 5000 digital camera attached to the eyepiece of the microscope.

For $70 \%$ of the species, material was available. Slides used for this study are deposited at the Nationaal Herbarium Nederland, Utrecht branch.

\section{DESCRIPTION - Table 2}

In surface view - Fig. $2 \mathrm{~d}$

Adaxial side - Indument lacking in Bocageopsis, Onychopetalum, and Unonopsis p.p.; if present, consisting of appressed or erect, uniseriate simple trichomes of 1-6 cells, (75-) 100-450(-775) $\mu \mathrm{m}$ long, (7-)10-15 $\mu \mathrm{m}$ thick, 5-10(-30) $/ \mathrm{mm}^{2}$, apical cell pointed. Unspecialized epidermal cells polygonal (more or less rectangular to jigsaw-like), $12-38(-58)$ by $7-25(-33) \mu \mathrm{m}$, anticlinal walls straight. Druses present in epidermal cells of most species. Secretory cells $10-50 / \mathrm{mm}^{2}$, present in all species of Bocageopsis and Onychopetalum and in 30\% of the species of Unonopsis.

Abaxial side - Indument present in most species, consisting of appressed or erect, uniseriate simple trichomes of $1-10$ cells, $(25-) 80-500(-1100) \mu \mathrm{m}$ long, (7-)10-15 $(-25) \mu \mathrm{m}$ thick, 5-20(-400) $/ \mathrm{mm}^{2}$, apical cell pointed. Unspecialized epidermal cells 
Table 1. Vouchers for leaf anatomical studies.

\begin{tabular}{|c|c|c|c|}
\hline Name & Slide. nr. & Country & Collector \\
\hline \multicolumn{4}{|l|}{ Bocageopsis } \\
\hline B. canescens & B - 714 & Brazil & Prance et al. 5049 \\
\hline B. mattogrossensis & B - 548 & Brazil & Prance et al. 19249 \\
\hline B. mattogrossensis & B -713 & Brazil & Dziewa 18 \\
\hline B. multiflora & B - 547 & Suriname & Maas et al. LBB 10736 \\
\hline B. multiflora & B - 616 & Brazil & Prance et al. 22714 \\
\hline B. multiflora & B - 712 & Brazil & Prance et al. 10812 \\
\hline B. pleiosperma & B - 2388 & Brazil & Prance et al. 3791 \\
\hline \multicolumn{4}{|l|}{ Onychopetalum } \\
\hline O. amazonicum & B - 661 & Brazil & Krukoff 6909 \\
\hline O. amazonicum & B - 908 & Brazil & Fróes 32206 \\
\hline O. periquino & B - 546 & Brazil & M.R. Cordeiro 1065 \\
\hline O. periquino & B - 2389 & Brazil & Krukoff 8214 \\
\hline \multicolumn{4}{|l|}{ Unonopsis } \\
\hline U. asterantha & B - 2408 & Peru & Pirie et al. 117 \\
\hline U. aurantiaca & B - 2391 & Brazil & Maas et al. 8825 \\
\hline U. aviceps & B - 2390 & Colombia & De Bruijn 1599 \\
\hline U. bahiensis & B - 2403 & Brazil & Thomas et al. 10908 \\
\hline U. bahiensis & B - 2404 & Brazil & Mori et al. 9727 \\
\hline U. bullata & B - 2413 & Panama & Maas et al. 9532 \\
\hline U. cauliflora & B - 2411 & Colombia & Lawrance 636 \\
\hline U. aff. costaricensis & B - 2412 & Costa Rica & G. Herrera et al. 2691 \\
\hline U. duckei & B - 733 & Brazil & Prance et al. 2171 \\
\hline U. duckei & B - 2392 & Brazil & Dionizia et al. 92 \\
\hline U. elegantissima & B - 2393 & Peru & Chatrou et al. 250 \\
\hline U. floribunda & B - 558 & Brazil & Krukoff 4806 \\
\hline U. floribunda & B - 739 & Brazil & Krukoff 5992 \\
\hline U. floribunda & B - 2394 & Ecuador & Balslev et al. 97176 \\
\hline U. glaucopetala & B - 738 & Suriname & Van Donselaar 3782 \\
\hline U. glaucopetala & B - 2395 & Guyana & Polak et al. 63 \\
\hline U. guatterioides & B - 557 & Brazil & Mexia 6030 \\
\hline U. guatterioides & B - 735 & Brazil & Prance et al. 58562 \\
\hline U. guatterioides & B - 736 & Suriname & $B W 2060$ \\
\hline U. guatterioides & B - 968 & Peru & Rimachi Y. 2224 \\
\hline U. heterotricha & B - 2410 & Brazil & Campbell et al.P22532 \\
\hline$U$. longipes & B - 2418 & Colombia & Gentry et al. 36957 \\
\hline U. macrocarpa & B - 2397 & Panama & Folsom et al. 4364 \\
\hline U. magnifolia & B - 2396 & Ecuador & C. Aulestia et al. 196 \\
\hline U. mexicana & B - 2407 & Mexico & Wendt et al. 5684 \\
\hline U. monticola & B - 2406 & Peru & J. Campos et al. 4324 \\
\hline U. osae & B - 2416 & Costa Rica & Maas et al. 9499 \\
\hline U. pacifica & B - 2398 & Colombia & Maas et al. 6503 \\
\hline U. penduliflora & B - 2420 & Costa Rica & O. Vargas 493 \\
\hline U. perrottetii & B - 2399 & Guyana & Persaud 165 \\
\hline U. peruviana & B - 2400 & Peru & Maas et al. 6270 \\
\hline U. riedeliana & B - 2401 & Brazil & Riedel s.n. \\
\hline U. rufescens & B - 556 & Suriname & Schulz LBB 9314 \\
\hline U. sanctae-teresae & B - 2405 & Brazil & Maas et al. 8832 \\
\hline U. sanctae-teresae & B - 2409 & Brazil & Maas et al. 8832 \\
\hline U. sericea & B - 2414 & Colombia & Soejarto et al. 3605 \\
\hline U. sessilicarpa & B - 2419 & Colombia & J.G. Ramírez et al. 485 \\
\hline U. spectabilis & B - 2415 & Peru & Gentry et al. 16146 \\
\hline U. stevensii & B - 2417 & Costa Rica & Grayum et al. 9822 \\
\hline U. stipitata & B - 734 & Suriname & Van Donselaar 3513 \\
\hline U. storkii & B - 2421 & Panama & Maas et al. 9526 \\
\hline U. theobromifolia & B - 2422 & Costa Rica & Maas et al. 9463 \\
\hline U. veneficiorum & B - 2402 & Ecuador & W. Palacios et al. 7891 \\
\hline
\end{tabular}




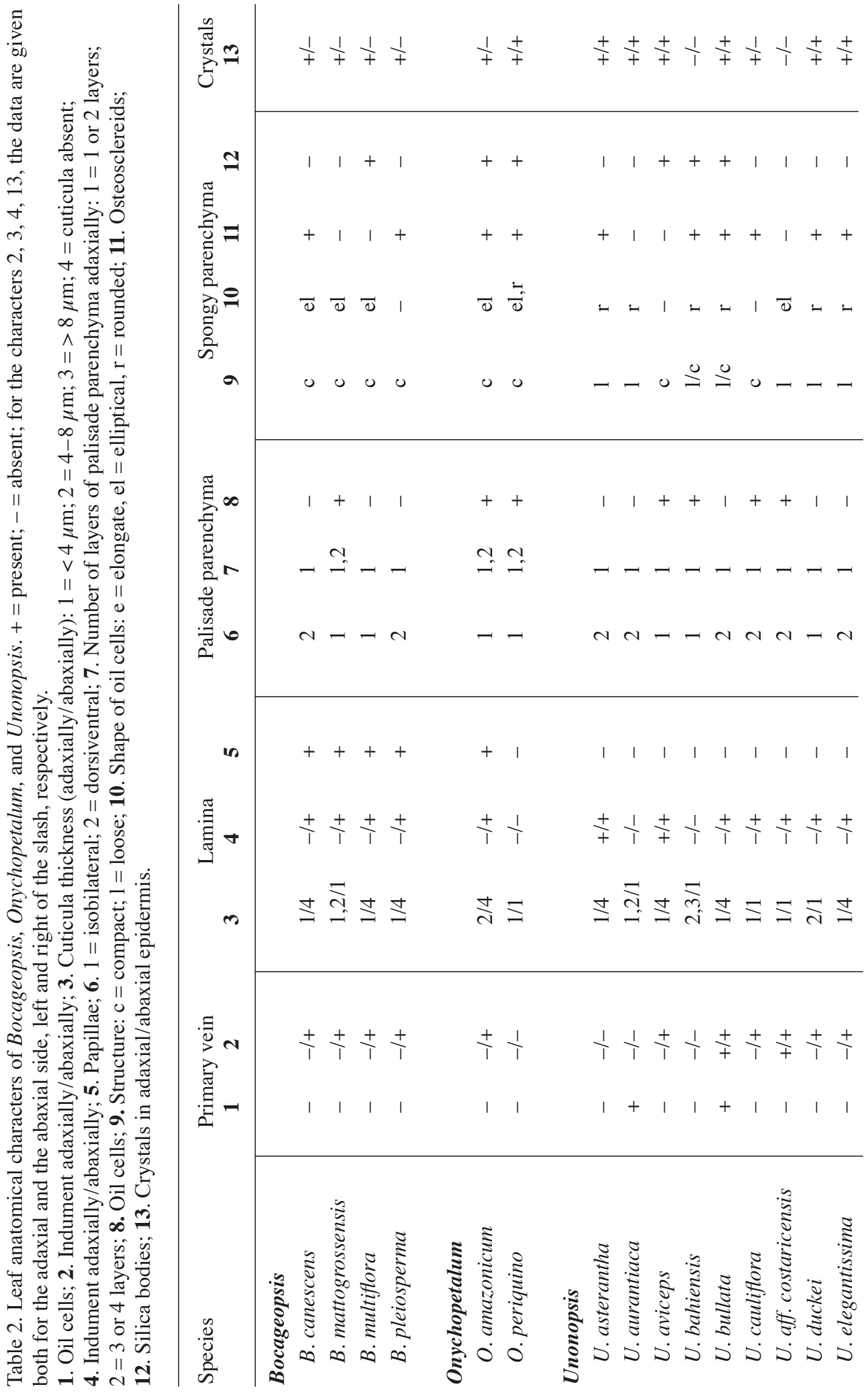


总岛

坣

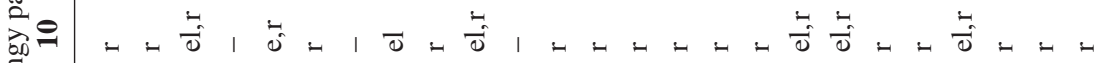
के

a $-\stackrel{0}{=}-00-00-00-00-00$

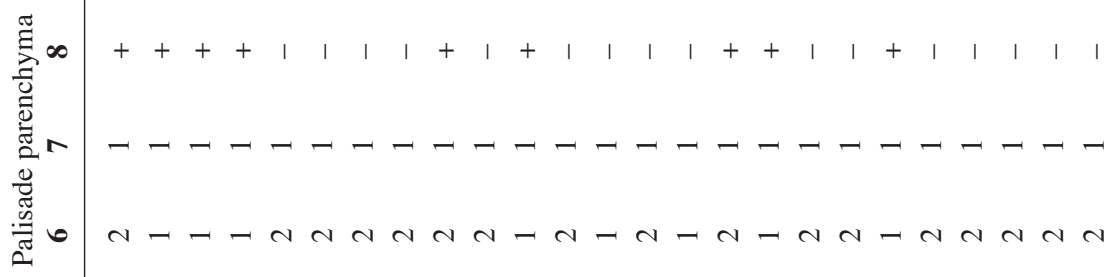

恳

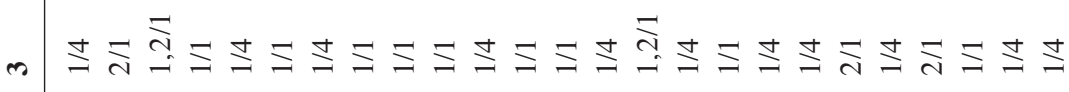

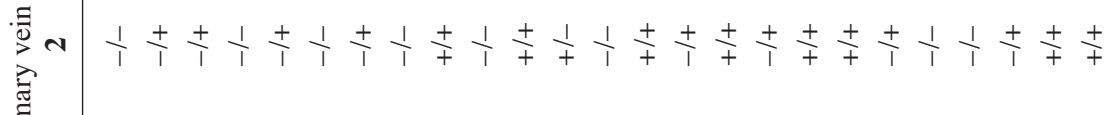
禀-

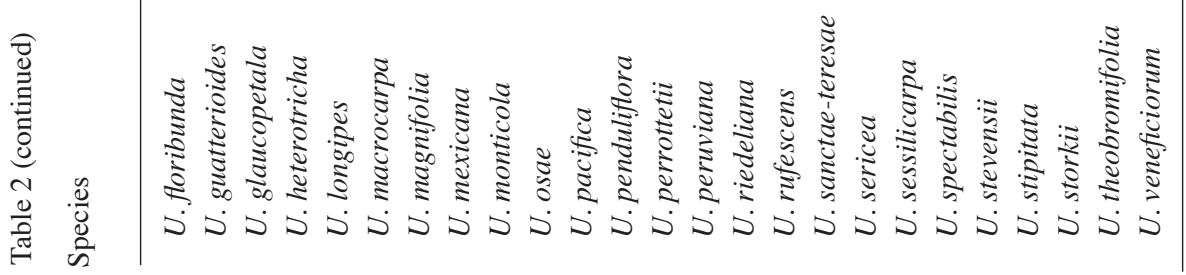


polygonal (more or less rectangular to jigsaw-like), (10-)15-43(-50) by (7-)10-20 $(-25) \mu \mathrm{m}$, anticlinal walls straight to undulate. Stomata paracytic, rounded to slightly elongate, regularly distributed, on the level of the unspecialized epidermal cells, (12-)15$25(-33)$ by $(7-) 12-20(-25) \mu \mathrm{m},(160-) 200-500(-600) / \mathrm{mm}^{2}$. Druses often present in epidermal cells of most species. Secretory cells only found in Unonopsis p.p.

In transverse section - Fig. $2 \mathrm{a}-\mathrm{c}, 3 \mathrm{a}, \mathrm{b}$

Lamina dorsiventral or isobilateral, (85-)125-250(-420) $\mu \mathrm{m}$ thick.

Cuticula 1-5(-9) $\mu \mathrm{m}$ thick adaxially, smooth, and $0-2(-4) \mu \mathrm{m}$ thick abaxially, if present smooth.

Epidermis adaxially 1-layered, except for 1- or 2-layered in U. glaucopetala and $U$. sanctae-teresae, smooth, (7-)12-25(-40) $\mu \mathrm{m}$ thick, abaxially 1-layered, 5-15(-28) $\mu \mathrm{m}$, smooth in Unonopsis to papillate in Bocageopsis and one species of Onychopetalum.
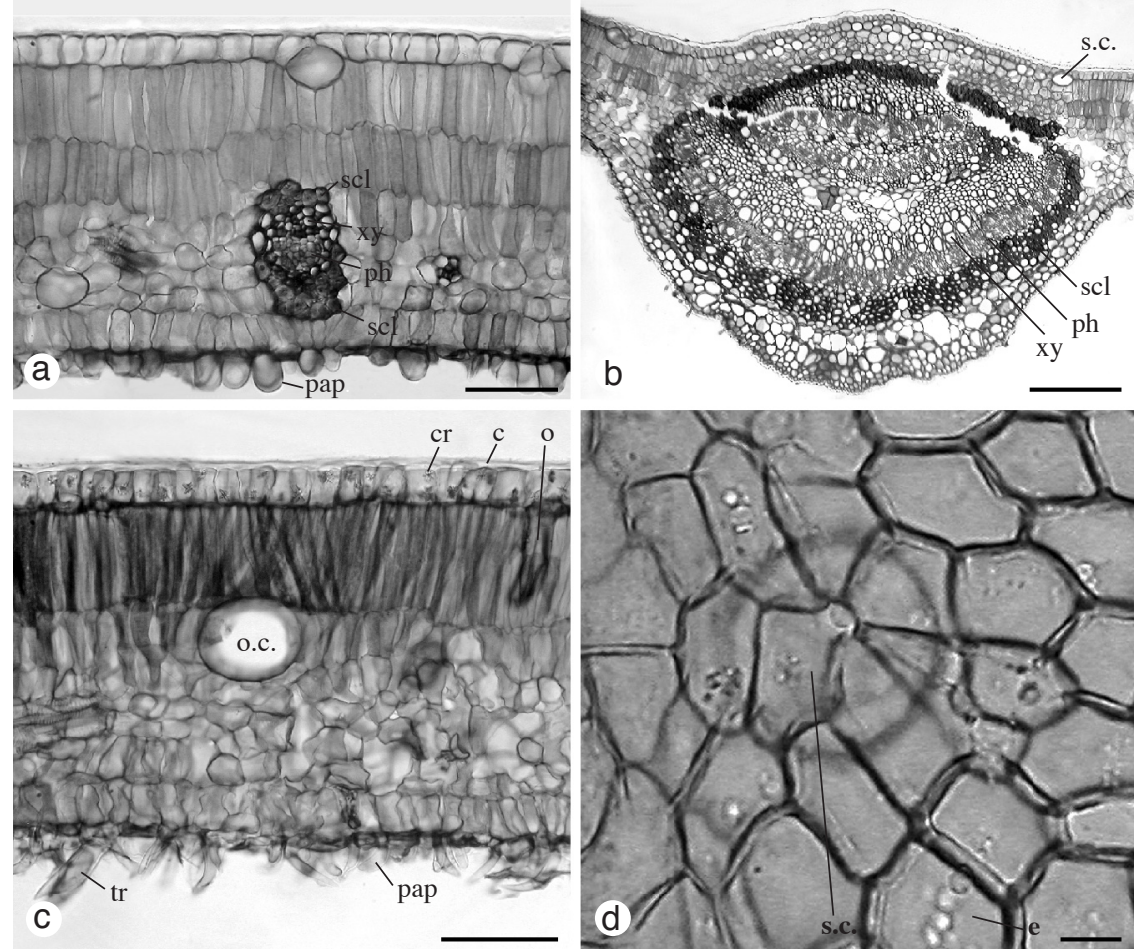

Fig. 2. a, b: Bocageopsis mattogrossensis. a. Transverse leaf section, showing isobilateral mesophyll with secondary vein and oil cell; adaxial epidermis with cuticula and secretory cell; $b$. transverse section showing primary vein with phloem island included in xylem tissue. - c, d: Onychopetalum amazonicum. c. Transverse leaf section, showing isobilateral mesophyll with oil cell and osteosclereid; adaxial epidermis with cuticula and crystals; abaxial epidermis with trichomes and papillae; d. adaxial epidermis: unspecialised cells with underlying secretory cell (a, b: Prance et al. 19249; c, d: Fróes et al. 32206). Abbreviations: c = cuticula; cr = crystals; e = epidermis; o = osteosclereid; o.c. $=$ oil cell; pap = papillae; $\mathrm{ph}=$ phloem; $\mathrm{scl}=$ sclerenchyma; s.c. $=$ secretory cell $; \mathrm{tr}=$ trichomes; $\mathrm{xy}=$ xylem. - Scale bars: $\mathrm{a}, \mathrm{c}=50 \mu \mathrm{m}, \mathrm{b}=125 \mu \mathrm{m}, \mathrm{d}=10 \mu \mathrm{m}$. 

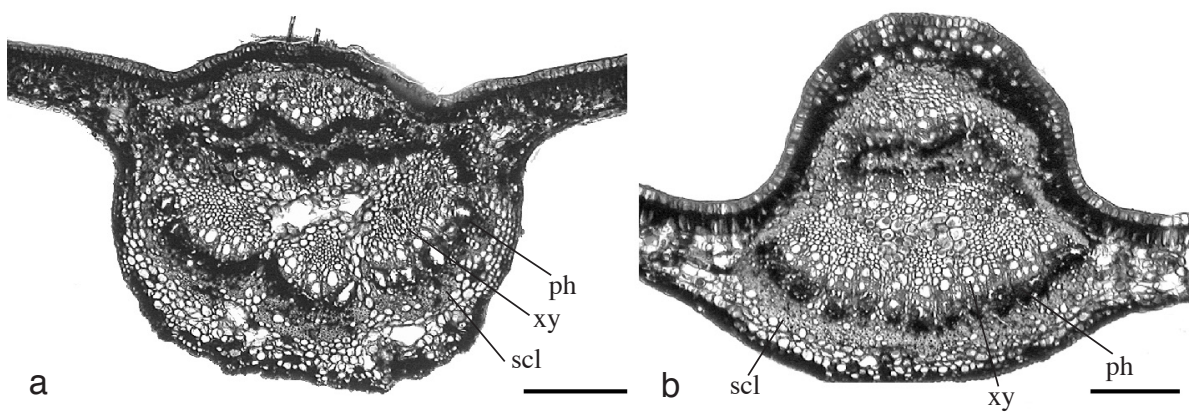

Fig. 3. a. Unonopsis peruviana. Transverse section showing primary vein and continuing palisade parenchyma at the adaxial side. - b. Unonopsis osae. As a. but with strongly raised primary vein (a: Maas et al. 6270; b: Maas et al. 9499). Abbreviations: $\mathrm{ph}=$ phloem; $\mathrm{scl}=$ sclerenchyma; $\mathrm{xy}=\mathrm{xylem}$. - Scale bars: $\mathrm{a}, \mathrm{b}=250 \mu \mathrm{m}$.

Mesophyll composed of 1 or 2 (or 3) layers of palisade parenchyma, 40-145 $\mu \mathrm{m}$ thick, and 2-6(-9) layers of loose to compact spongy parenchyma. In isobilateral lamina the abaxial palisade parenchyma 1-layered, (12-)20-30(-38) $\mu \mathrm{m}$ thick. Oil cells present in all genera in the palisade parenchyma, in the spongy parenchyma, or in both, often with a coloured content. Osteosclereids present in most species and reaching from the adaxial to the abaxial side. Silica bodies present in the spongy parenchyma in all species of Onychopetalum and in some species of Unonopsis and Bocageopsis. In the spongy and the palisade parenchyma crystals usually lacking.

Primary vein always raised adaxially; the vascular bundle surrounded by a continuous layer of sclerenchyma. In the xylem tissue an additional island of sclerenchyma fibres and phloem tissue is embedded. Stone cells and few oil cells and druses present in the ground tissue at the abaxial side of the vascular tissue. In Unonopsis a continuous layer of palisade parenchyma can be found as part of the adaxial ground tissue.

Terminal veins collateral with a narrow sclerenchymatic cap reaching abaxially into the spongy parenchyma and adaxially up to the palisade parenchyma.

\section{DISCUSSION}

The results presented here are in accordance with, and an addition to those given earlier by Van Setten \& Koek-Noorman (1986). Bocageopsis, Onychopetalum, and Unonopsis fall within the leaf anatomical variation as known for the Neotropical genera of the Annonaceae (Van Setten \& Koek-Noorman, 1986), as well as the Palaeotropical genera (Van Marle, unpublished results).

Leaf anatomically, the three genera together are recognizable by a combination of characters: the topography of the primary vein, a raised primary vein, the presence of secretory cells in the epidermis, and osteosclereids and silica bodies in the mesophyll. However, some of these features are lacking in part of the species.

There are no individual features by which Bocageopsis, Onychopetalum, and Unonopsis can be distinguished with certainty on the base of leaf anatomy. The papillae on the abaxial epidermis, intermingled with short, appressed trichomes, are found in all 
species of Bocageopsis, but are also present in Onychopetalum amazonicum. The secretory cells in the adaxial epidermis, characteristic for Bocageopsis and Onychopetalum, are also found in some species of Unonopsis. Both species of Onychopetalum have silica bodies. These, however, are also found in part of the species in the two other genera.

Within Bocageopsis and Onychopetalum, individual species can be distinguished from each other by combining different features (Table 2). However, when more samples were studied within some species of Unonopsis (viz. U. bahiensis, U. floribunda, U. glaucopetala, U. guatterioides), the variation in both qualitative and quantitative character states is too large to allow any distinction between those species.

\section{SYSTEMATIC TREATMENT}

\section{KEY TO THE THREE GENERA}

1a. Flower buds ellipsoid to broadly ellipsoid; inner petals with an apical, incurved appendage up to $3 \mathrm{~mm}$ long; monocarps subsessile (stipes $0-1 \mathrm{~mm}$ long); number of monocarps 1 or 2; secondary veins often impressed above 2. Onychopetalum

b. Flower buds generally globose, never ellipsoid; inner petals without an apical appendage or sometimes (Bocageopsis p.p.) with a minute apical adaxial outgrowth $<0.5 \mathrm{~mm}$ long; monocarps stipitate to subsessile; number of monocarps 1-100; secondary veins impressed to slightly raised above $\ldots \ldots \ldots \ldots \ldots \ldots 2$

2a. Monocarps mostly distinctly stipitate; leaves mostly symmetrical; connective shield of anthers discoid; secondary veins often impressed above . . . . 3. Unonopsis

b. Monocarps subsessile (stipes to $2 \mathrm{~mm}$ long); leaves mostly asymmetrical; connective shield of anthers tongue-shaped; secondary veins flat to slightly raised above ...

1. Bocageopsis

\section{BOCAGEOPSIS - Plate $1 \mathrm{a}-\mathrm{e}$}

Bocageopsis R.E. Fr. (1931) 143, f. 1e, 2. - Lectotype (selected by Fries, 1959: 102): Bocageopsis multiflora (Mart.) R.E. Fr. [झ Bocagea multiflora Mart.].

Trees or shrubs 1.5-36 m tall; leafy twigs densely to sparsely covered with appressed or erect, simple hairs when young, soon becoming glabrous. Leaves distichous, simple, entire, shortly petiolate, exstipulate; lamina mostly small and narrowly elliptic, asymmetrical, leaf index varying from 1.7-4.8, chartaceous, sometimes coriaceous, when dry not or less often densely covered with minute wartlike outgrowths (verruculose), base acute to obtuse, apex acuminate, sometimes acute, upper side glabrous, lower side sparsely covered with appressed, simple hairs, papillate, venation brochidodromous, primary vein raised above and below, secondary veins mostly distinct, straight to curved, between 9-20 on either side of the primary vein, flat to slightly raised above, angles with primary vein $40-70^{\circ}$, loop-forming at acute to obtuse angles, smallest distance between loops and margin $0.5-3 \mathrm{~mm}$, tertiary veins distinct, reticulate to percurrent. Inflorescences on older branches, sometimes among leaves, compact or sometimes sublax distally, composed of 2-c. 10 rhipidia, mostly sessile; rhipidia few-flowered ( $\leq 6$ flowers in succession), sympodial rachis manifest or not; upper bract at $1 / 5-2 / 3$ from the base of the pedicel, mostly broadly ovate, $0.5-1 \mathrm{~mm}$ long. Indument: inflo- 
rescence, including peduncles, pedicels, sympodial rachis, outer side of bracts, sepals, outer petals, and exposed part of inner petals densely to sparsely covered with appressed or erect, simple hairs. Flower buds globose or broadly to very broadly ovoid. Flowers actinomorphic, bisexual, perianth consisting of one whorl of sepals and two whorls of petals; sepals three, valvate, free to basally connate, much smaller than the petals; petals six, valvate, cream, white, or green, the outer ones ovate to depressed ovate, flat or slightly concave, the inner ones ovate to broadly ovate, concave, with or without a minute apical adaxial outgrowth $<0.5 \mathrm{~mm}$ long; torus cylindrical to cushionshaped; stamens mostly numerous, spirally arranged, extrorse, connective shield tongue-shaped, acute to obtuse, glabrous, sometimes papillate; carpels few, spirally arranged, free, ovary 1-locular with 2-4, lateral ovules, densely covered with appressed hairs, stigma (narrowly) ellipsoid, discoid, or lobed, glabrous. Fruit apocarpous, composed of 1-5, free monocarps, often with persistent sepals; monocarps transversally to broadly ellipsoid, fleshy, green, yellow, orange, or red, to black, 5-17 mm diam., densely covered with appressed to erect hairs to glabrous, apex rounded, sometimes apiculate (apiculum $<0.1 \mathrm{~mm}$ long), wall $0.1-0.6 \mathrm{~mm}$ thick, stipes of monocarps $0-2$ mm long, glabrous, sometimes covered with appressed to erect hairs. Seeds 1-4 per monocarp, lateral, in 1 row, mostly transversally ellipsoid, glabrous, often dark brown, pitted, with a distinct canaliculate raphe completely surrounding the seed, aril absent, ruminations spiniform.

Chromosome number $-2 \mathrm{n}=18$ (Morawetz, pers. comm.).

Distribution -4 species, restricted to tropical South America, East of the Andes.

Habitat \& Ecology - In non-inundated forest, rarely in periodically inundated forest, or even savannahs. At low elevations, rarely up to $900 \mathrm{~m}$.

Note - The name is derived from Bocagea (Annonaceae) and 'opsis' (Old Greek 'face'), because of the superficial resemblance with that genus from SE Brazil. Bocagea A. St.-Hil. (Saint-Hilaire, 1825: 41) was named after the poet J.M. Souza du Bocage: "In memoriam dixi Josephi Mariae de Souza du Bocage, vatis ingeniosi, qui Castelii poema de floribus in versus lusitanicos elegantissimè convertit commentariolisque botanicis illustravit" ("I have spoken in memory of Joseph Maria de Souza du Bocage, the talentful poet, who set the poem on flowers by Castelius into Portuguese verses in an exemplary way and elucidated it with brief botanical comments").

\section{KEY TO THE SPECIES OF BOCAGEOPSIS}

1a. Apex of lamina mostly acute; monocarps glaucous. - Brazil (Goiás, Minas Gerais, Pará, Paraná) . . . . . . . . . . . . . . . . 2. B. mattogrossensis

b. Apex of lamina always acuminate; monocarps not glaucous . . . . . . . . 2

2a. Monocarps densely covered with appressed hairs; secondary veins of lamina 9-15. - Throughout the Amazon Region . . . . . . . . . . . 1. B. canescens

b. Monocarps sparsely covered with appressed hairs to finally glabrous; secondary

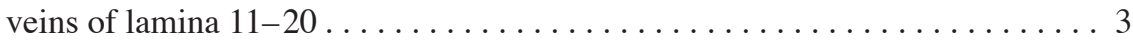

3a. Monocarps 5-9 by 5-8 mm; seeds 6-7 mm long; number of seeds 1 or 2 . - Ama-

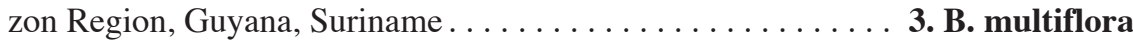

b. Monocarps $8-17$ by $10-13 \mathrm{~mm}$, seeds $10-11 \mathrm{~mm}$ long; number of seeds 1-4. - Amazonian Brazil (Amazonas, Pará) . . . . . . . . . 4. B. pleiosperma 
1. Bocageopsis canescens (Benth.) R.E. Fr. - Fig. 4; Plate 1a-c; Map 1

Bocageopsis canescens (Benth.) R.E. Fr. (1931) 147, f. 2c. - Trigynaea canescens Benth. (1860) 70. - Bocagea canescens Spruce ex Benth. (1860) 70, nom. nud. - Type: Spruce 3549 (holo $\mathrm{K}$; iso B, BM, BR, F, G, GH, K, OXF, P), Venezuela, Amazonas, Río Guainía towards Río Casiquiare, August 1854.

Tree or shrub 1.5-36 m tall, 6-40 cm diam.; young twigs densely covered with appressed and erect hairs, soon glabrous. Leaves: petiole 2-7 mm long, 1-2 mm diam.; lamina narrowly elliptic to elliptic, rarely narrowly ovate, symmetrical to slightly falcate, $5-15$ by $2-5 \mathrm{~cm}$ (leaf index $1.7-4.3$ ), mostly coriaceous, not to densely verruculose,
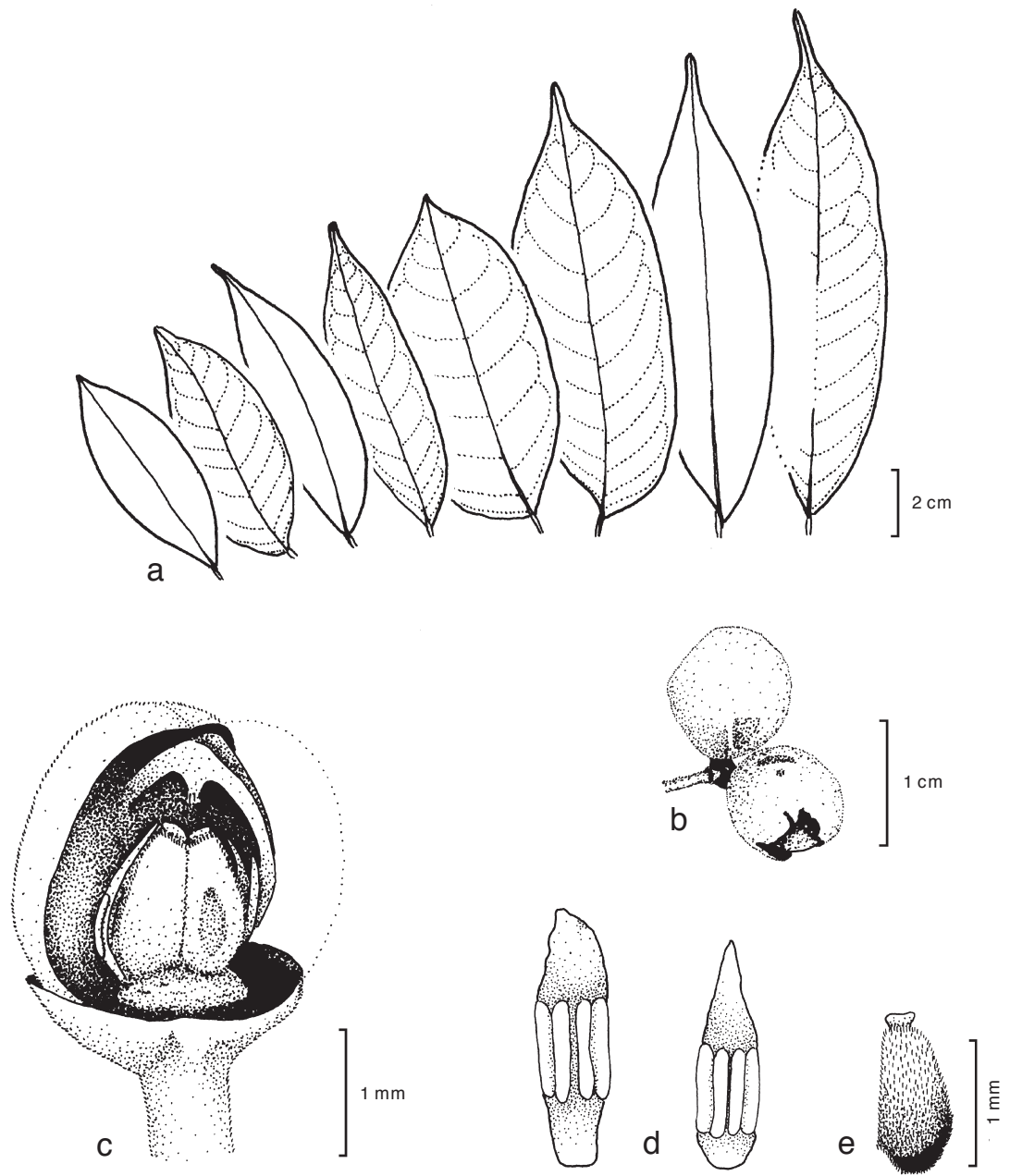

Fig. 4. Bocageopsis canescens (Benth.) R.E. Fr. a. Variation in leaf shape showing leaves of different collections; b. fruit; c. flower bud with part of petals and stamens, and 1 carpel removed; d. stamens, showing variation; e. carpel (a: various collections; b: Fróes et al. 25308; c, e: Vásquez \& Jaramillo 11160; d: Defler 24). - Drawing by M. Vermeer. 
dull above, grey to dark brown above, brown, sometimes greyish green below, glabrous above, sparsely covered with appressed hairs below, base obtuse to acute, apex acuminate (acumen 5-20 mm long), secondary veins indistinct, curved to straight, 9-15 on either side of primary vein, flat to raised above, angles with primary vein $40-60^{\circ}$, loop-forming at acute to obtuse angles, smallest distance between loops and margin 1-2 mm, tertiary veins distinct, reticulate to slightly percurrent. Inflorescences on older branches, less often among leaves, compact, composed of $2-5$ rhipidia, sessile; rhipidia 1- or 2-flowered, to 4 flowers in succession; upper bract at 1/3-1/2 from the base of the pedicel, broadly (to very broadly) ovate, $0.5-1 \mathrm{~mm}$ long, outer side densely covered with appressed and erect hairs; pedicels 4-17 mm long, c. $0.5 \mathrm{~mm}$ diam., fruiting pedicels to $25 \mathrm{~mm}$ long, to $1 \mathrm{~mm}$ diam., densely covered with appressed and erect hairs; flower buds globose to very broadly ovoid; sepals basally connate to free, ovate to broadly ovate, $1-1.5$ by $1 \mathrm{~mm}$, outer side densely covered with appressed and erect hairs; petals green, white, or cream in vivo, outer ones ovate to very broadly ovate, $2-3\{-6\}$ by $2-3\{-5\} \mathrm{mm}$, outer side densely covered with appressed and erect hairs, inner ones ovate to broadly ovate, $2-3\{-6\}$ by $2\{-4\} \mathrm{mm}$, rarely with a minute apical adaxial outgrowth $<0.5 \mathrm{~mm}$ long, outer side glabrous except for hairy exposed part; stamens 1-2 mm long; carpels 2-4, 1-1.5 mm long, densely covered with appressed hairs, ovules 1 or 2, lateral. Monocarps $1-4$, green, yellow, to orange in vivo, grey, greyish orange, greyish brown, to greyish black in sicco, globose to ellipsoid, 9-13 by 7-11 mm, densely covered with appressed, greyish hairs, apex rounded, not apiculate, wall $0.1-0.4 \mathrm{~mm}$ thick, stipes $0-2$ by $1-3 \mathrm{~mm}$. Seeds 1 or 2, lateral, $6-10$ by $6-10$ by 3-6(-9) mm, orange-brown to dark red.

Distribution - Amazonian Brazil (Acre, Amazonas, Rondônia), Colombia (Amazonas, Vaupés), Peru (Loreto), Venezuela (Amazonas).

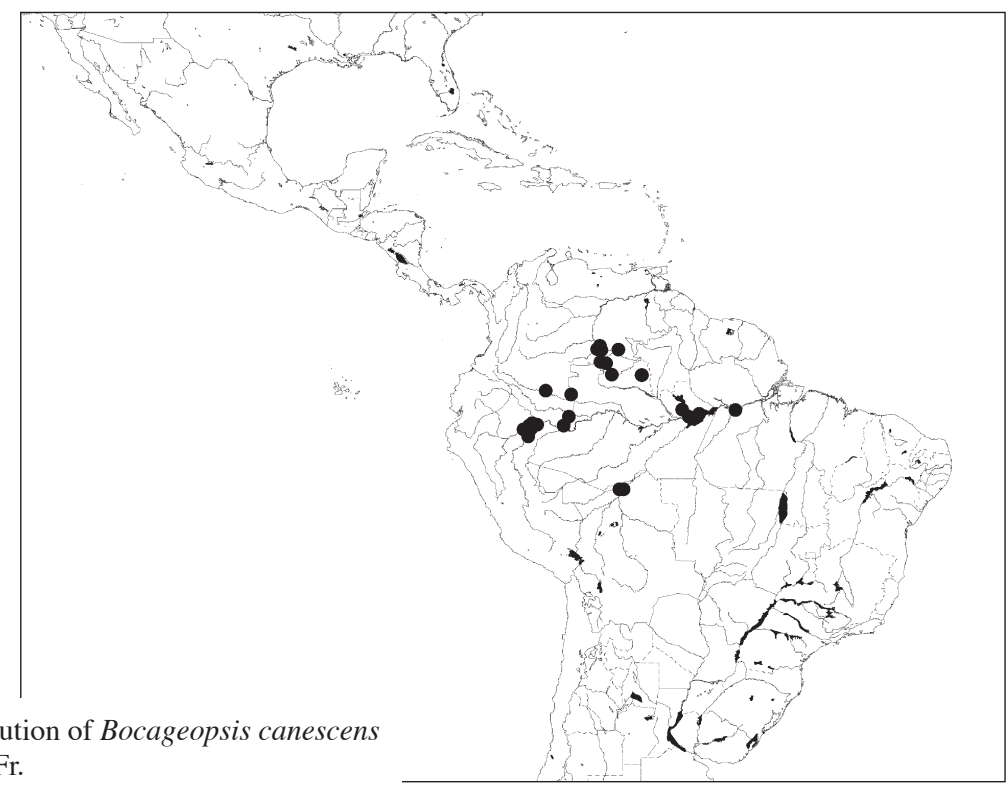

Map 1. Distributior
(Benth.) R.E. Fr. 
Habitat \& Ecology - In non-inundated forest, sometimes in periodically inundated forest, savannah, or montane forest, mostly on clay or white sand. At elevations of 0-300 m. Flowering: April to December; fruiting: throughout the year.

Vernacular names - Colombia: Sarïmï (Muinane). Peru: Anonilla, Espintana, Icoja. Venezuela: Caño iguapo, Majagua.

Note - Bocageopsis canescens is easily recognized by the dense, greyish indument of the monocarps. In the past it has been confused with B. mattogrossensis, but it differs from that species by the lower number of secondary veins (9-15 vs 16-20), and the leaf apex (acuminate vs mostly acute).

\section{Bocageopsis mattogrossensis (R.E. Fr.) R.E. Fr. - Fig. 5; Map 2}

Bocageopsis mattogrossensis (R.E. Fr.) R.E. Fr. (1931) 147, f. 2b. - Bocagea mattogrossensis R.E. Fr. (1905) 12, t. 4, f. 1-4. - Type: Malme II-2390 (holo S), Brazil, Mato Grosso, Santa Ana de Chapada, 26 September 1902.

Tree or shrub 3-18 $\mathrm{m}$ tall, 6-60 cm diam.; young twigs densely covered with appressed and erect hairs, soon glabrous. Leaves: petiole 2.5-5 mm long, 1-2 mm diam.; lamina narrowly elliptic to narrowly ovate, symmetrical to falcate, $7-14$ by $1.5-4 \mathrm{~cm}$ (leaf index 2.8-4.7), chartaceous to coriaceous, dull above, not or sparsely verruculose near primary vein, greyish brown to greenish brown above, brown below, glabrous above, sparsely to rather densely covered with appressed hairs below, base obtuse, apex acute to sometimes acuminate (acumen 5-15 mm long), secondary veins indistinct, straight (to curved), 16-20 on either side of primary vein, raised above, angles with primary vein $40-65^{\circ}$, loop-forming at acute to obtuse angles, smallest distance between loops and margin 1-2 mm, tertiary veins distinct, reticulate to slightly percurrent. Inflorescences

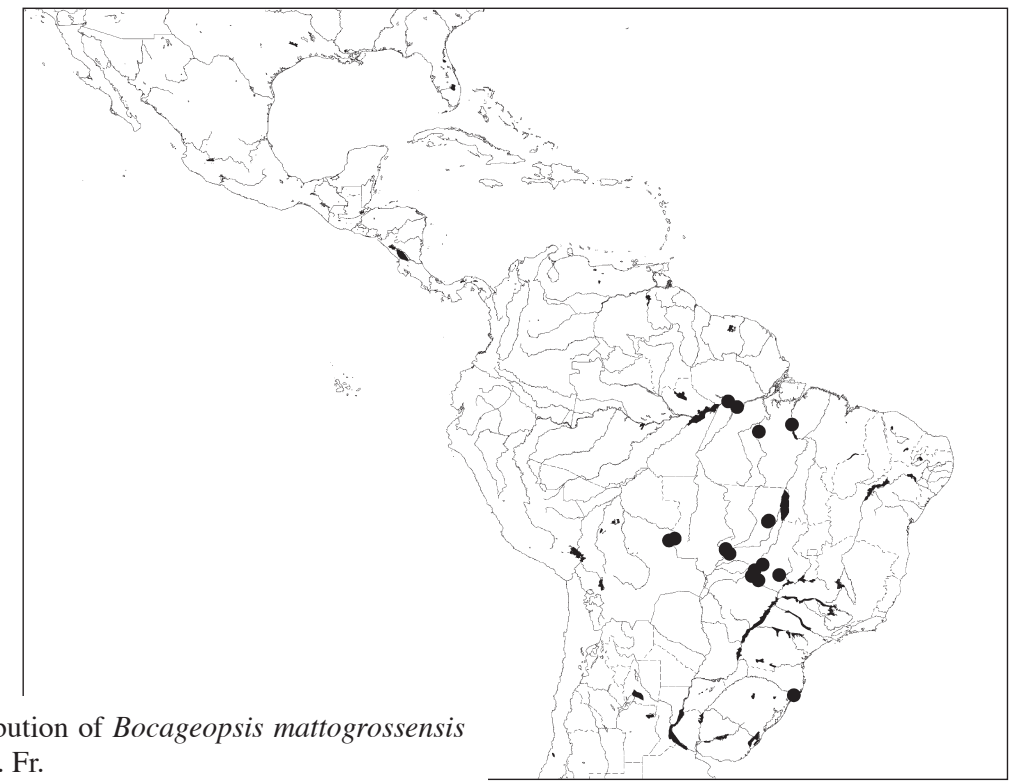

Map 2. Distribution
(R.E. Fr.) R.E. Fr. 
c
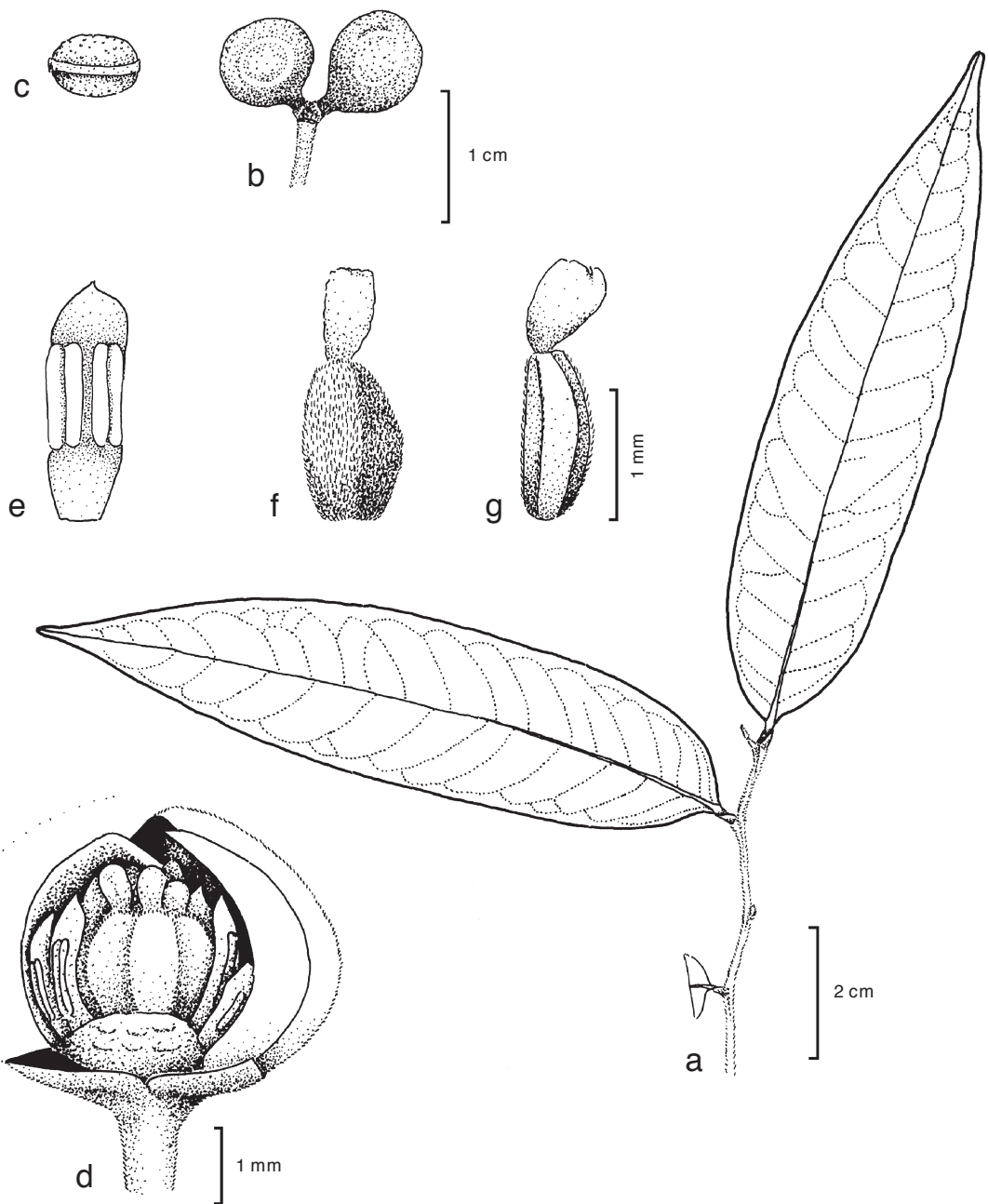

Fig. 5. Bocageopsis mattogrossensis (R.E. Fr.) R.E. Fr. a. Leafy twig; b. fruit; c. seed; d. flower bud with part of petals and stamens removed; e. stamen; f. carpel in abaxial view; g. carpel in lateral view, also showing variation of indument (a, c: Magnago 347; b: Harley et al. 10843; d-f: Ducke RB 17869; g: R.R. de Santos et al. 1247). — Drawing by M. Vermeer.

on older branches, less often among leaves, compact, composed of 3-5 rhipidia, sessile; rhipidia 1- or 2-flowered, to 5 flowers in succession, sympodial rachis to $3 \mathrm{~mm}$ long; upper bract at 1/5-1/2 from the base of the pedicel, very broadly to depressed ovate, c. $1 \mathrm{~mm}$ long, outer side densely covered with appressed and erect hairs; pedicels 5-15 $\mathrm{mm}$ long, c. $0.5 \mathrm{~mm}$ diam., fruiting pedicels to $30 \mathrm{~mm}$ long, to $2 \mathrm{~mm}$ diam., densely covered with appressed and erect hairs; flower buds globose to very broadly ovoid; sepals free, broadly to depressed ovate, $1-1.5$ by $1-1.5 \mathrm{~mm}$, outer side densely covered with appressed and erect hairs; petals greenish, maturing white or cream in vivo, 
outer ones very broadly ovate to ovate, $4-5$ by $4 \mathrm{~mm}$, outer side densely covered with appressed and erect hairs, inner ones elliptic to ovate, $3-4$ by $3 \mathrm{~mm}$, without apical outgrowth, outer side glabrous except for hairy exposed part; stamens 1-2 mm long; carpels 4-7, 1-1.5 mm long, densely covered with appressed hairs, ovules 2, lateral. Monocarps 1-5, glaucous, green to yellow, pink, and finally purplish black in vivo, brownish black to purplish black in sicco, globose to ellipsoid, 7-13 by 7-12 $\mathrm{mm}$, sparsely covered with appressed, long hairs to finally glabrous, apex rounded, not apiculate, wall $0.1-0.6 \mathrm{~mm}$ thick, stipes $1-2$ by $1-2 \mathrm{~mm}$. Seeds 1 or 2, lateral, 7-9 by $6-8$ by $4-5 \mathrm{~mm}$, orange to dark red.

Distribution - Brazil (Goiás, Mato Grosso, Pará, Paraná), Bolivia (Santa Cruz).

Habitat \& Ecology - In gallery forest, transitionary forest (between cerrado and dry forest), cerrado, and in secondary vegetations, on clayey to sandy soil. At elevations up to $900 \mathrm{~m}$. Flowering: throughout the year; fruiting: May to November.

Vernacular names - Brazil: Envira, Mejo de porco de cerrado.

Note - Bocageopsis mattogrossensis is recognized by often acute leaves and by glaucous monocarps.

\section{Bocageopsis multiflora (Mart.) R.E. Fr. - Fig. 6; Plate 1d, e; Map 3}

Bocageopsis multiflora (Mart.) R.E. Fr. (1931) 145, f. 2a. - Bocagea multiflora Mart. (1831) 45, t. 14. - Guatteria multiflora Poepp. ex Baill. (1868a) 216, nom. nud. - Type: Poeppig 2668 (lecto BR, selected here; iso BM, F, G, GOET, HAL n.v., K, M, P), Brazil, Amazonas, Téfé ('Ega'), October 1831.

Bocageopsis multiflora (Mart.) R.E. Fr. var. angustifolia R.E. Fr. (1931) 146, syn. nov. - Type: Ducke RB 19633 (holo S; iso K, RB), Brazil, Amazonas, Manaus, 18 October 1927.

Tree 7-27 m tall, 15-45 cm diam.; young twigs sparsely covered with appressed hairs, soon glabrous. Leaves: petiole 3-6 mm long, 0.5-1.5 mm diam.; lamina narrowly elliptic, symmetrical to slightly falcate, $6-13$ by $1.5-4 \mathrm{~cm}$ (leaf index $2.5-4.8$ ), chartaceous, not verruculose, dull above, greyish brown to brown above, brown below, glabrous above, sparsely to rather densely covered with appressed hairs below, base obtuse to acute, apex acuminate (acumen 5-30 mm long), secondary veins indistinct, straight, 14-20 on either side of primary vein, impressed to raised above, angles with primary vein $55-70^{\circ}$, loop-forming at acute to obtuse angles, smallest distance between loops and margin 1-2 mm, tertiary veins distinct, reticulate to slightly percurrent. Inflorescences among leaves or on older branches, compact, to sometimes sublax distally, composed of 2-10(-15) rhipidia, peduncle-like base $0-2 \mathrm{~mm}$, axial internodes in distal parts sometimes to $2 \mathrm{~mm}$ long; rhipidia 1-3-flowered, to 6 flowers in succession, sympodial rachis to $6 \mathrm{~mm}$ long; upper bract at 1/5-3/5 from the base of the pedicel, broadly to very broadly ovate, $0.5-1 \mathrm{~mm}$ long, outer side densely covered with appressed hairs; pedicels $6-13 \mathrm{~mm}$ long, c. $0.5 \mathrm{~mm}$ diam., fruiting pedicels to 20 $\mathrm{mm}$ long, to $1 \mathrm{~mm}$ diam., densely covered with appressed hairs; flower buds broadly to very broadly ovoid; sepals free, sometimes basally connate, broadly to depressed ovate, c. 1 by $1-1.5 \mathrm{~mm}$, outer side densely covered with appressed hairs; petals green, maturing white to cream in vivo, outer ones broadly to very broadly ovate, $3-4\{-6\}$ by $3\{-4\} \mathrm{mm}$, outer side densely covered with appressed hairs, inner ones ovate to very broadly ovate, $3\{-4\}$ by $2-3 \mathrm{~mm}$, with or without a minute apical adaxial outgrowth 

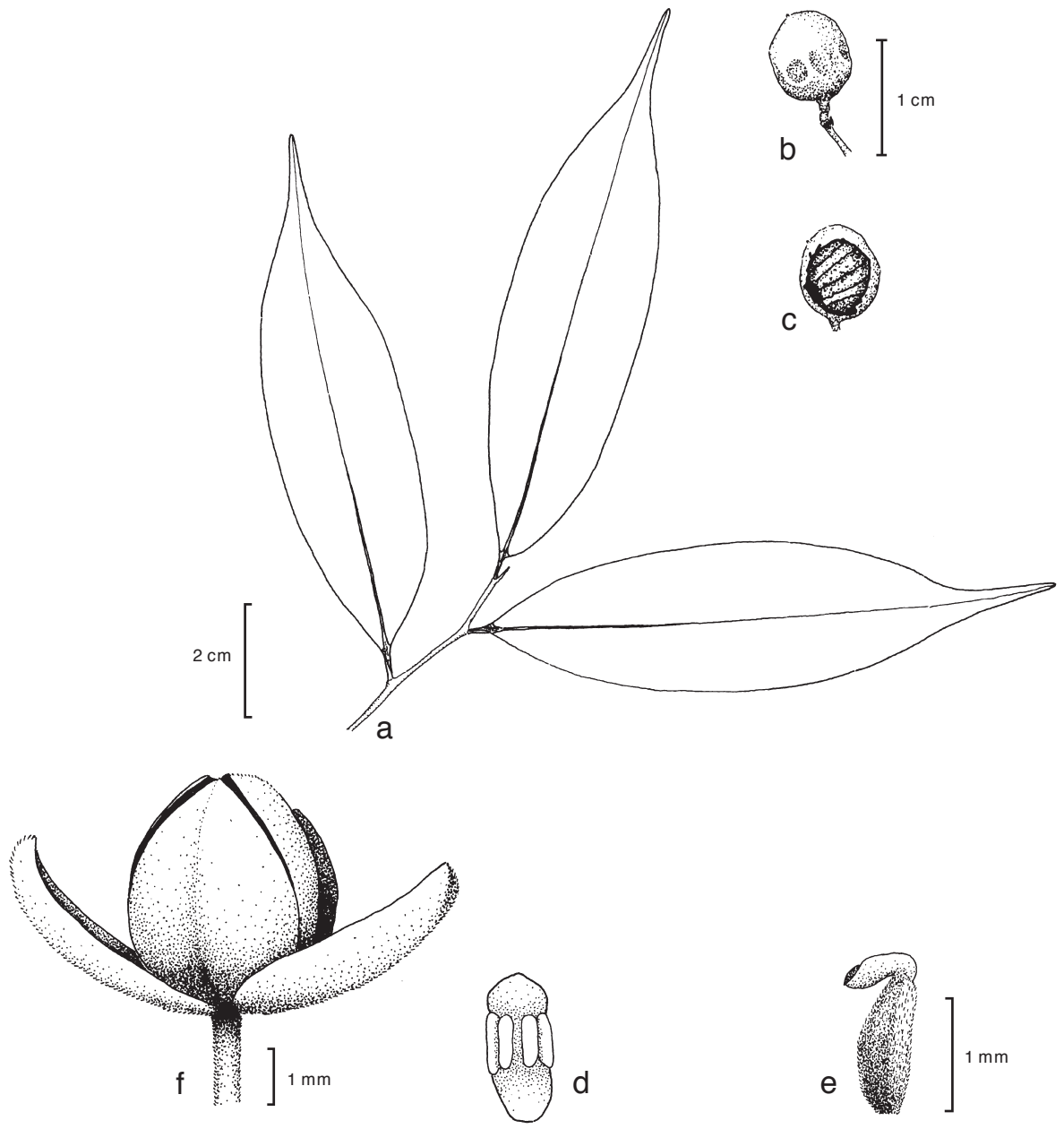

Fig. 6. Bocageopsis multiflora (Mart.) R.E. Fr. a. Leafy twig; b. monocarp; c. opened monocarp showing orientation of 2 seeds; d. stamen; e. carpel; f. flower at anthesis (a: Breteler 4780; b: Aymard \& Delgado 8146; c: N.T. Silva 1504; d-f: Jansen-Jacobs et al. 3179). — Drawing by M. Vermeer.

$<0.5 \mathrm{~mm}$ long, outer side glabrous except for hairy exposed part; stamens $1-1.5 \mathrm{~mm}$ long; carpels 4-7, 1-1.5 mm long, densely covered with appressed hairs, ovules 2 (or 3 ), lateral. Monocarps 1-5, orange to yellow, maturing black in vivo, reddish black, dark red, to dark brownish black in sicco, transversely to broadly ellipsoid, $5-9$ by $6-8$ $\mathrm{mm}$, sparsely covered with appressed, long hairs to finally glabrous, apex rounded to apiculate (apiculum $<0.1 \mathrm{~mm}$ long), wall $0.2-0.3 \mathrm{~mm}$ thick, stipes $1-2$ by $1-2 \mathrm{~mm}$. Seeds 1 or 2 , lateral, $6-7$ by $5-6$ by $4-5 \mathrm{~mm}$, orange-brown.

Distribution - Amazonian parts of Bolivia (Beni, Pando), Brazil (Amazonas, Mato Grosso, Rondônia, Roraima), Colombia (Amazonas), Venezuela (Amazonas, Bolívar), and in Guyana and Suriname. 


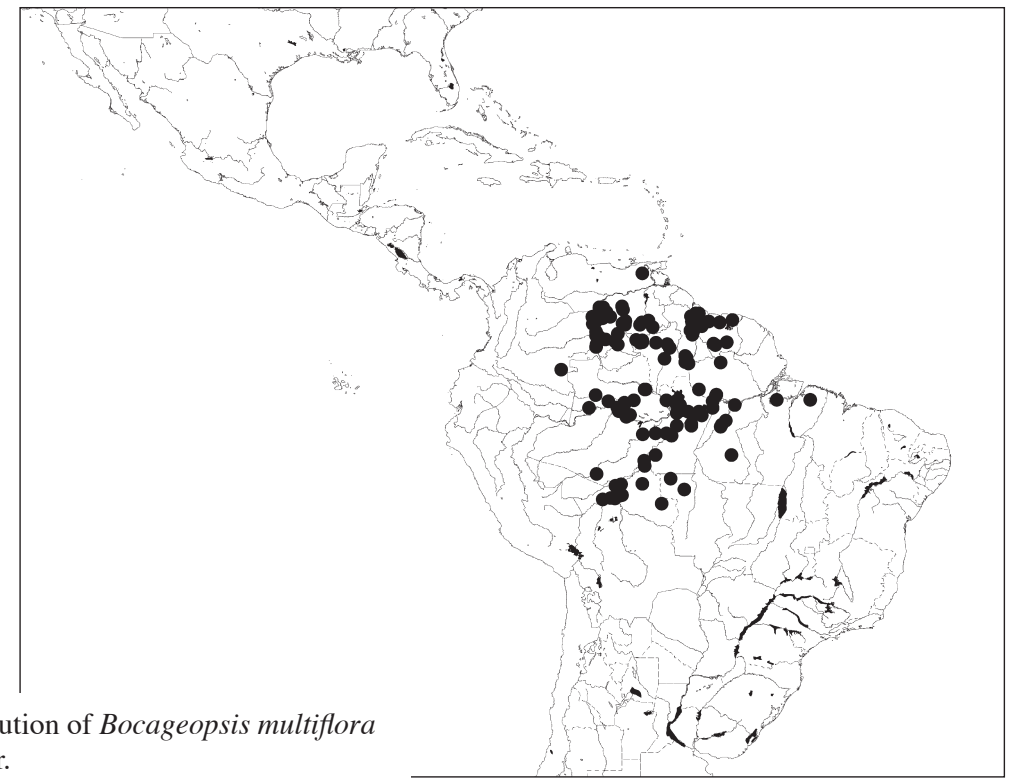

Map 3. Distribution of Bocageopsis multiflora (Mart.) R.E. Fr.

Habitat \& Ecology - In non-inundated or periodically inundated forest, savannah forest, or in savannahs, on clayey to sandy soil. At elevations up to $850 \mathrm{~m}$. Flowering: February to November; fruiting: throughout the year.

Vernacular names - Bolivia: Piriquina. Brazil: Ata meju, Envira, Envira preta, Envira surucucú, Envireira, Envireira preta, Gabiroba, Invira surucucu, Invireiro surucucu, Morteira. Guyana: Arara (Arawak), Black yariyari (Arawak). Suriname: Boszuurzak (Surinamese Dutch), Kleinbladige yariyari (Surinamese Dutch), Man pikapika (Sranang), Panta (Sranang), Pegreku pisi (Sranang), Pikapika (Sranang), Yariyari (Sranang), Zwarte pegreku. Venezuela: Anoncillo, Aradek, Arara-yek (Arekuna), Caña iguapo (aguas negras), Cärärä Dau, Edisha, Erisha, Fructo e' burro montañero A, Karara, Majagua, Majagua negra, Pipirri, Yara Yara.

Note - Bocageopsis multiflora is the most common species of the genus. It is recognized by its almost glabrous young twigs and by the long-acuminate leaf apex.

\section{Bocageopsis pleiosperma Maas - Fig. 7; Map 4}

Bocageopsis pleiosperma Maas in Maas et al. (1986) 249, f. 1, 3a. - Type: Silva \& Rosário 3927 (holo U; iso INPA, MG, MO, NY, US), Brazil, Pará, Parque Nacional de Tapajós, km 60 of Itaituba-Jacarecanga Hwy., 26 November 1978.

Tree 8-28 $\mathrm{m}$ tall, to $40 \mathrm{~cm}$ diam.; young twigs rather densely to densely covered with appressed and erect hairs, soon glabrous. Leaves: petiole $2.5-8 \mathrm{~mm}$ long, $1-1.5 \mathrm{~mm}$ diam.; lamina narrowly elliptic, slightly asymmetrical, $7-17$ by $2.5-5 \mathrm{~cm}$ (leaf index $2.3-3.7$ ), chartaceous, not verruculose, dull above, (greyish) brown above, brown (to grey) below, glabrous above, sparsely to rather densely covered with appressed hairs below, base obtuse to acute, apex acuminate (acumen 5-15 $\mathrm{mm}$ long), secondary 

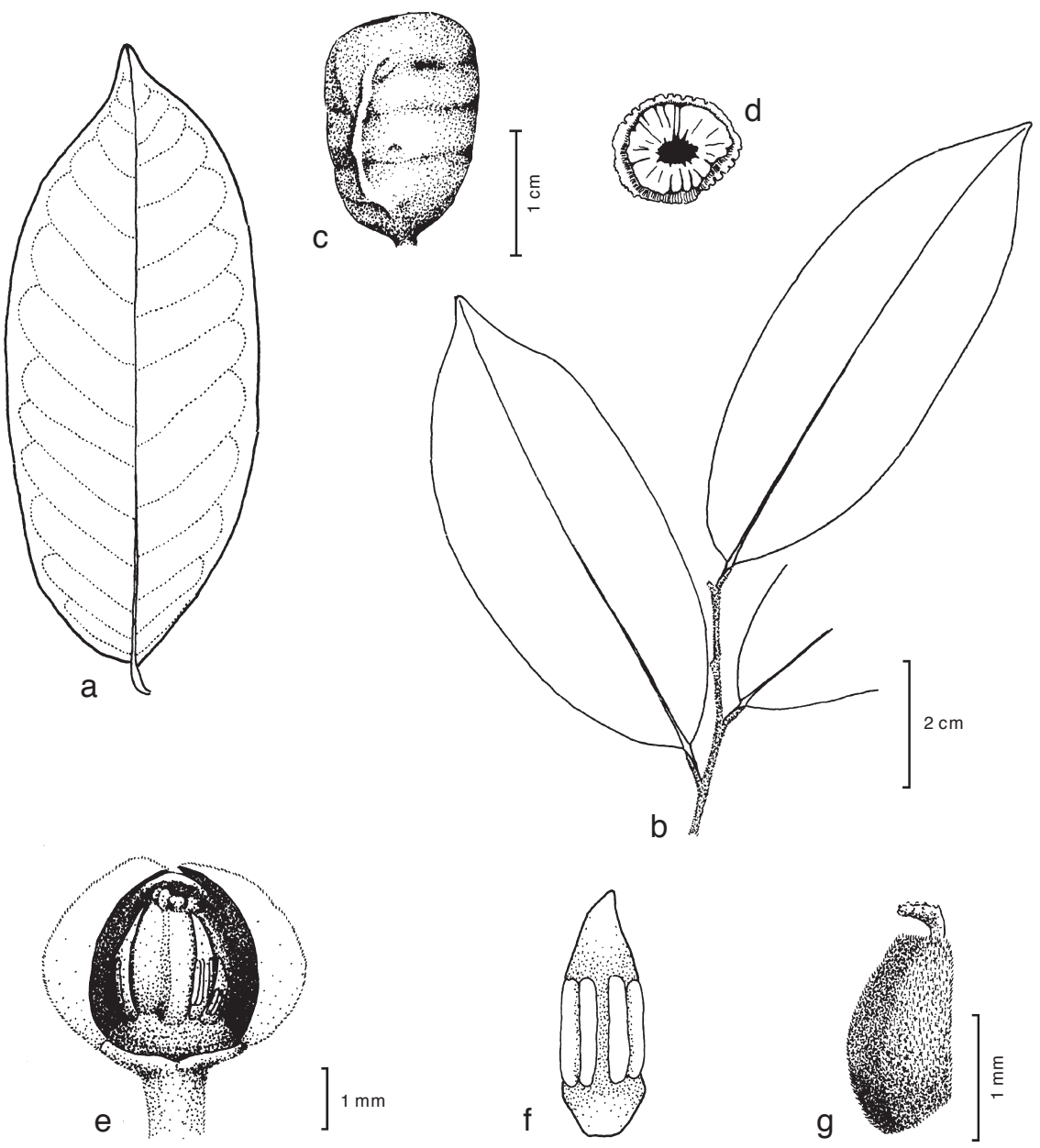

Fig. 7. Bocageopsis pleiosperma Maas. a. Leaf; b. leafy twig; c. monocarp; d. x.s. of seed; e. flower bud with part of petals and stamens removed; f. stamen; g. carpel (a, c, d: M. G. Silva \& Rosário 3927; b: Sothers et al. 145; e: Ribeiro et al. 1045; f, g: Sothers et al. 513). - Drawing by M. Vermeer.

veins indistinct, curved to straight, 11-18 on either side of primary vein, raised above, angles with primary vein $40-60^{\circ}$, loop-forming at acute to obtuse angles, smallest distance between loops and margin 1-3 mm, tertiary veins distinct, weakly percurrent to reticulate. Inflorescences among leaves or on older branches, compact, to sublax distally, composed of 2-10 rhipidia, sessile, axial internodes in distal parts to $2 \mathrm{~mm}$ long; rhipidia 1- or 2-flowered, to 4 flowers in succession; upper bract at 1/3-2/3 from the base of the pedicel, broadly to depressed ovate, $0.5-1 \mathrm{~mm}$ long, outer side densely covered with appressed and erect hairs; pedicels 5-16 mm long, c. $0.5 \mathrm{~mm}$ diam., fruiting pedicels to $2.5 \mathrm{~mm}$ diam., densely covered with appressed and erect hairs; flower buds broadly to very broadly ovoid; sepals free, broadly to very broadly ovate, 


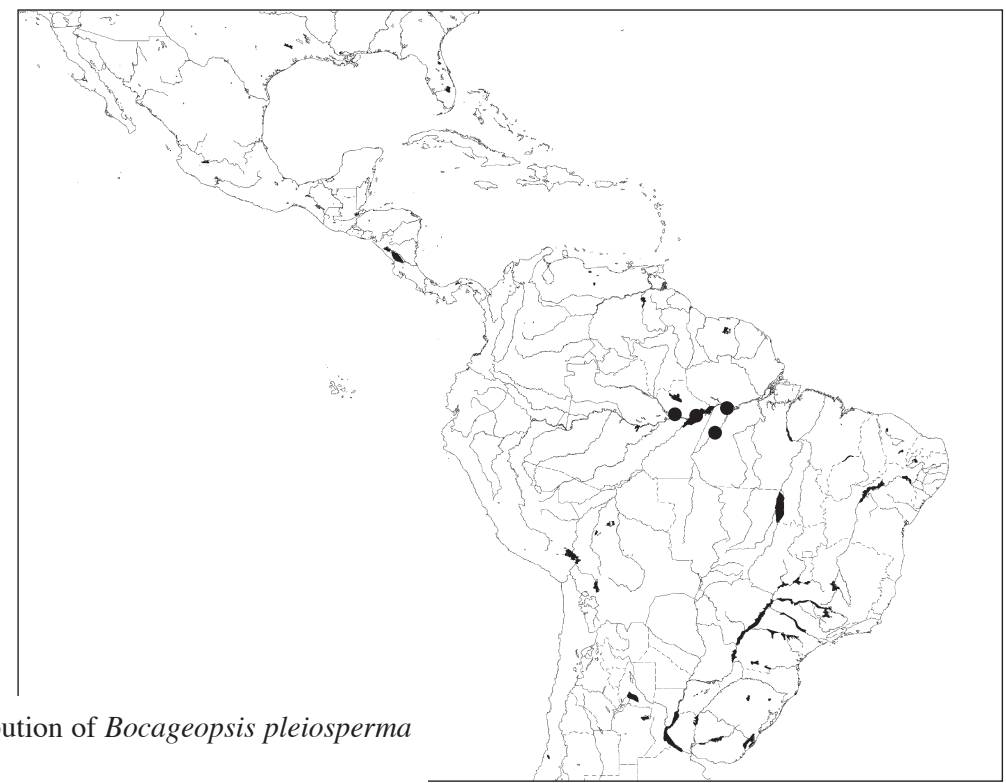

Map 4. Distribution of Bocageopsis pleiosperma Maas.

c. 1 by $1 \mathrm{~mm}$, outer side densely covered with appressed and erect hairs; petals cream to pink in vivo, outer ones ovate to broadly ovate, $3-4$ by $3 \mathrm{~mm}$, outer side densely covered with appressed and erect hairs, inner ones elliptic to broadly elliptic, c. 3 by $2 \mathrm{~mm}$, without an apical outgrowth, outer side glabrous except for hairy exposed part; stamens 1-2 mm long; carpels 2 or 3, c. $1.5 \mathrm{~mm}$ long, densely covered with appressed hairs, ovules 3 or 4, lateral. Monocarps 1-4, green to red in vivo, brown to brownish black in sicco, depressed to broadly ellipsoid, 8-17 by $10-13 \mathrm{~mm}$ diam., sparsely covered with appressed, long hairs to finally glabrous, apex rounded, not apiculate, wall $0.2-0.4 \mathrm{~mm}$ thick, stipes $0-1$ by $2-3 \mathrm{~mm}$. Seeds $1-4$, lateral, $10-11$ by $8-10$ by 4-6 mm, dark red, sometimes orange-red.

Distribution - Amazonian Brazil (Amazonas, Pará).

Habitat \& Ecology - In non-inundated forest, on clayey or sand-clayey soil. At low elevations. Flowering: July to November; fruiting: August to November.

Vernacular names - Brazil: Envira preta, Jurueira sangue.

Note - Bocageopsis pleiosperma, only known from a handful of collections, is well distinguished from the other species of the genus by the larger number of seeds in the monocarps (1-4 vs 1 or 2 ), and the larger average size of the monocarps.

\section{ONYCHOPETALUM - Plate $1 \mathrm{f}$}

Onychopetalum R.E. Fr. (1931) 148, f. 2. - Type: Onychopetalum amazonicum R.E. Fr.

Trees 8-30 m tall, sometimes with red exudate; leafy twigs sparsely covered with appressed, simple hairs when young, soon becoming glabrous. Leaves distichous, simple, entire, shortly petiolate, exstipulate; lamina medium-sized to large, mostly narrowly 
elliptic, asymmetrical, leaf index varying from 1.5-4.4, chartaceous to coriaceous, when dry often densely covered, or not covered with minute wartlike outgrowths (verruculose) on both sides, but most visibly so above, base acute to obtuse, apex acuminate, sometimes acute, upper side glabrous, lower side densely covered with appressed, simple hairs to glabrous, papillate (O. amazonicum) or not, venation brochidodromous, primary vein raised above and below, secondary veins indistinct, straight to curved, between 13-24 on either side of the primary vein, impressed to raised above, angles with primary vein $40-70^{\circ}$, loop-forming at acute to obtuse angles, smallest distance between loops and margin 1-3.5 mm, tertiary veins indistinct, percurrent. Inflorescences on older branches, rarely among leaves, compact to sublax, composed of 2-15 (rarely more) rhipidia, sessile, rhipidia few-flowered ( $\leq 5$ flowers in succession), sympodial rachis not manifest; upper bract at 1/3-3/4 from the base of the pedicel, mostly depressed ovate, $0.5-2 \mathrm{~mm}$ long. Indument: inflorescence, including peduncles, pedicels, sympodial rachis, outer side of bracts, sepals, outer petals, and exposed part of inner petals densely to sparsely covered with appressed or erect, simple hairs. Flower buds ellipsoid to broadly ellipsoid, or broadly ovoid. Flowers actinomorphic, bisexual, perianth consisting of one whorl of sepals and two whorls of petals; sepals three, valvate, mostly connate, much smaller than the petals; petals six, valvate, cream, white, or green, the outer ones elliptic to narrowly elliptic or ovate, flat or slightly concave, the inner ones ovate to obovate or narrowly so, concave, with a distinct, incurved, apical, tail-like appendage; torus very broadly ovoid, cushion-shaped or flat; stamens few to numerous, spirally arranged, extrorse, connective shield tongue-shaped, acute to obtuse, glabrous, sometimes papillate; carpels 1 or 2 (or 3), spirally arranged, free, ovary 1-locular with 2-5, lateral ovules, covered with appressed hairs to glabrous, stigma cylindrical or ellipsoid, glabrous. Fruit apocarpous, composed of 1 or 2, free monocarps, often with persistent sepals; monocarps globose to ellipsoid, fleshy, green, orange to red, 24-60 mm diam., sparsely covered with appressed hairs to glabrous, apex rounded, sometimes apiculate (apiculum $<0.5 \mathrm{~mm}$ long), wall $0.2-2 \mathrm{~mm}$ thick, stipes of monocarps $0-0.5 \mathrm{~mm}$ long, glabrous, sometimes covered with appressed to erect hairs. Seeds 2-4 per monocarp, lateral, in 1 or 2 rows, transversely ellipsoid, glabrous, often dark brown, pitted, with a distinct canaliculate raphe completely surrounding the seed, aril absent, ruminations spiniform.

Chromosome number $-2 \mathrm{n}=18$ (Morawetz, pers. comm.).

Distribution - 2 species, restricted to the Amazon Region of South America.

Habitat \& Ecology - In non-inundated forest, rarely in periodically inundated or savannah forest. At low elevations up to $620 \mathrm{~m}$.

Note - The name is composed of 'onyx' (Old Greek 'claw', 'hook') and 'petalum', referring to the incurved apical appendage of the inner petals.

\section{KEY TO THE SPECIES OF ONYCHOPETALUM}

1a. Lamina glabrous below, 2.5-5 cm wide; secondary veins 13-17. - Amazonian Bolivia, Brazil, Peru . . . . . . . . . . . . . . . 2. O. periquino

b. Lamina densely covered with appressed, greyish hairs below, 3-11 cm wide; sec-

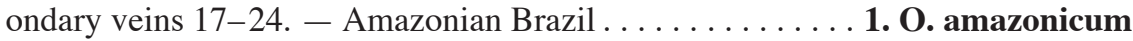




\section{Onychopetalum amazonicum R.E. Fr. - Fig. 8; Map 5}

Onychopetalum amazonicum R.E. Fr. (1931) 149, f. 3a-k. - Type: Ducke RB 11374 (holo S; iso

B, K, RB, US), Brazil, Pará, Obidos, Rio Curucambá, 30 October 1919.

Onychopetalum lanceolatum R.E. Fr. (1937) 266, f. 8a-e, syn. nov. - Type: Krukoff 6909 (holo S; iso A, BR, F, GH n.v., K, MICH, MO, NY, RB, S, U, US), Brazil, Amazonas, Mun. Humaitá, Rio Livramento, 30 October 1934.

Tree 10-30 m tall, 10-90 cm diam., sometimes with red exudate; young twigs sparsely covered with appressed hairs, soon glabrous. Leaves: petiole (4-)6-13 mm long, 1.5-4.5 mm diam.; lamina narrowly elliptic to elliptic, sometimes ovate, obovate, or

Fig. 8. Onychopetalum amazonicum R.E. Fr. a. Variation in leaf shape showing leaves of different collections; b. monocarp; c. seed; d. flower bud with part of petals and stamens removed; e. stamen; f. carpel (a: various collections; b: Campos \& Kukle 52: c: Krukoff 6909; d, e: Kawasaki et al. 366; f: A.A. Oliveira et al. 209). - Drawing by M. Vermeer.
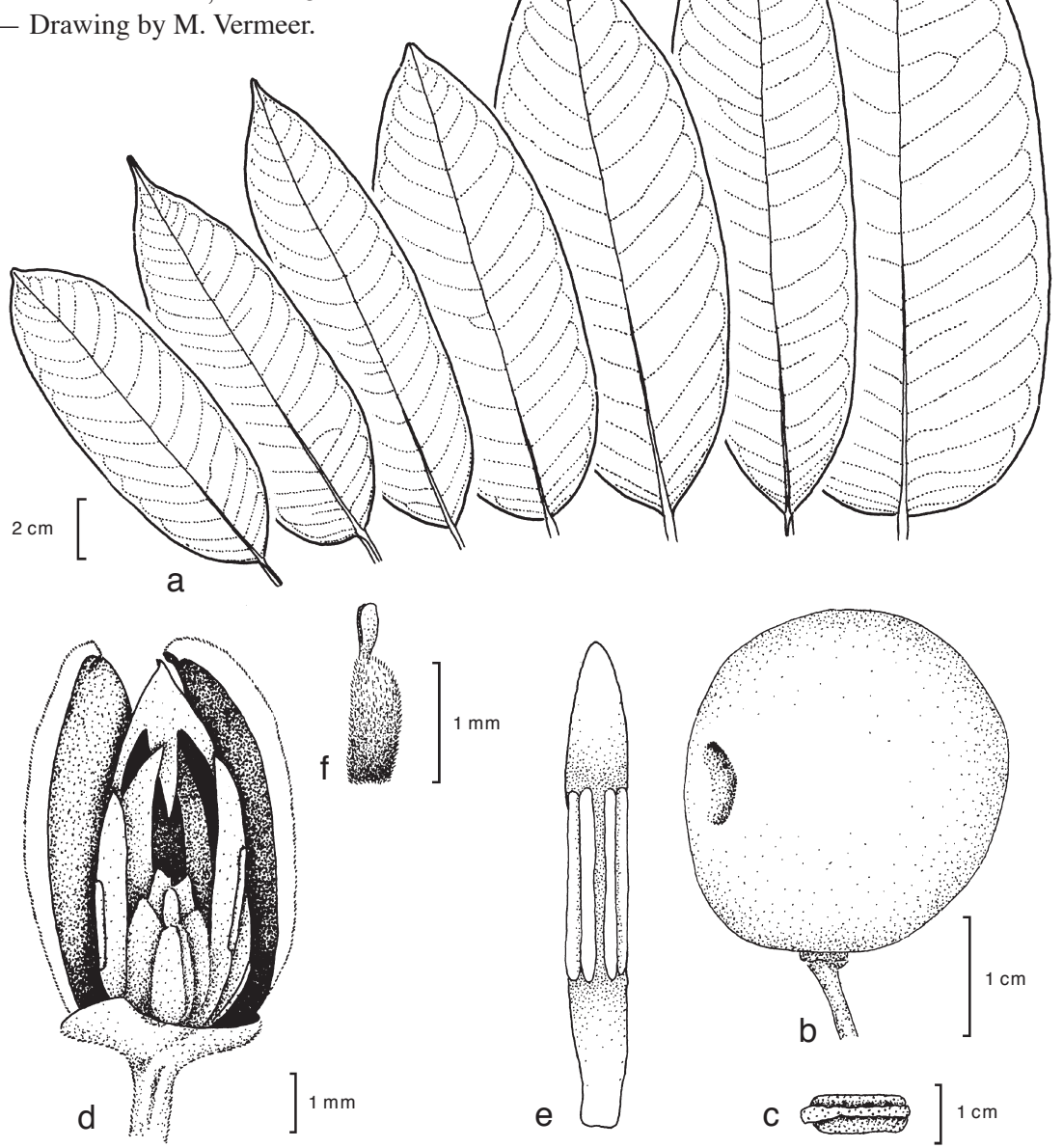
narrowly so, slightly asymmetrical, $6-30$ by $3-11 \mathrm{~cm}$ (leaf index $1.5-3.8$ ), coriaceous, sometimes chartaceous, densely or not verruculose, dull above, greyish brown to brown above, grey to brownish grey below, glabrous above, densely covered with appressed, greyish hairs below, base obtuse (to acute), apex acuminate (acumen 5-15 mm long), secondary veins indistinct, curved to straight, 17-24 on either side of primary vein, impressed, flat, or raised above, angles with primary vein $40-70^{\circ}$, loop-forming at acute to obtuse angles, smallest distance between loops and margin 1-4 $\mathrm{mm}$, tertiary veins indistinct, percurrent. Inflorescences on older branches, compact to sublax, composed of 5-15 rhipidia, sessile, axial internodes to $3 \mathrm{~mm}$ long; rhipidia 1- or 2-flowered, to 4 flowers in succession; upper bract at 1/3-3/4 from the base of the pedicel, depressed ovate to ovate, 1-2 mm long, outer side densely covered with appressed hairs; pedicels 3-15 mm long, 0.5-1 mm diam., fruiting pedicels to $20 \mathrm{~mm}$ long, 2-3 $\mathrm{mm}$ diam., densely covered with appressed hairs; flower buds ellipsoid to broadly ellipsoid; sepals basally to largely connate, broadly to depressed ovate, $1.5-2$ by $1-2 \mathrm{~mm}$, outer side densely covered with appressed hairs; petals greenish, maturing white to cream in vivo, outer ones elliptic to ovate, $5-9$ by $2.5-3 \mathrm{~mm}$, outer side densely covered with appressed hairs, inner ones elliptic to ovate, $4-8$ by $2-3 \mathrm{~mm}$, with an apical appendage $0.5-3 \mathrm{~mm}$ long, outer side glabrous except for hairy exposed part; stamens 1.5-5 mm long; carpels 1 or 2 (or 3), 1-2 mm long, densely covered with appressed hairs, ovules 2-5, lateral. Monocarps 1 or 2, green with yellow pulp in vivo, reddish brown to reddish black in sicco, globose to ellipsoid, $24-38$ by $22-30 \mathrm{~mm}$, sparsely covered with appressed hairs to finally glabrous, smooth to tuberculate, apex rounded to apiculate (apiculum $<0.5 \mathrm{~mm}$ long), wall $0.2-1 \mathrm{~mm}$ thick, stipes $0-1$ by $4-6 \mathrm{~mm}$. Seeds $2-4$, lateral, $16-24$ by $11-22$ by $2-14 \mathrm{~mm}$, red to black.

Distribution - Amazonian Brazil (Amazonas, Mato Grosso, Pará, Rondônia) and Venezuela (Amazonas).

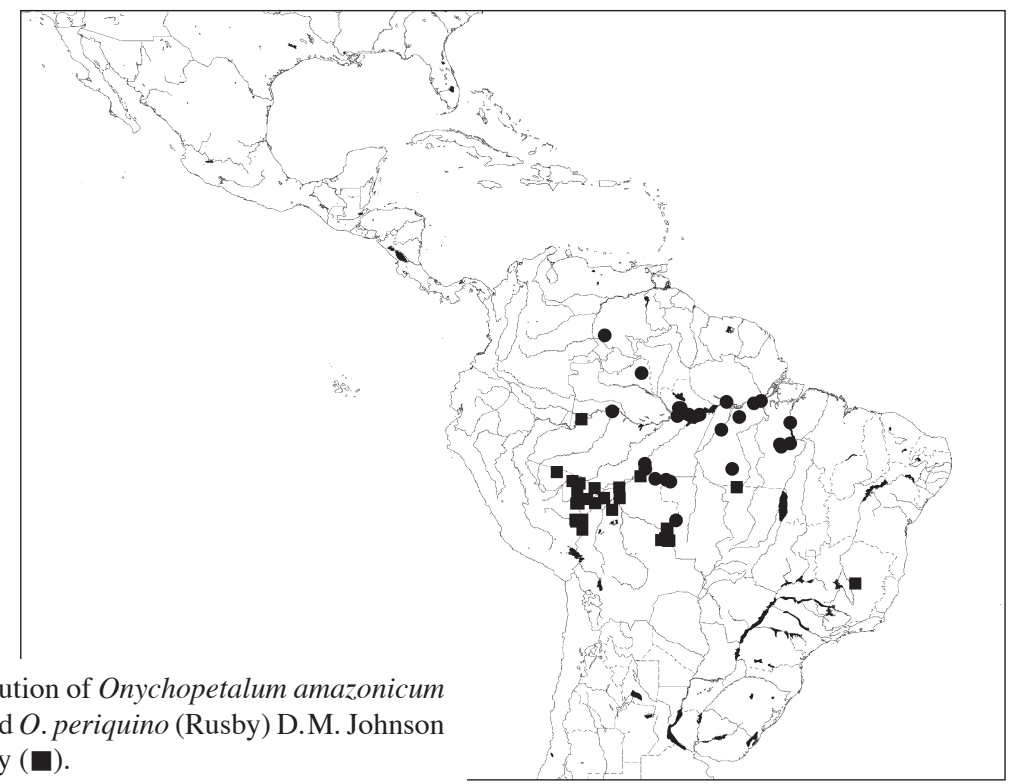

Map 5. Distribution of Onychopetalum amazonicum R.E. Fr. (O) and O. periquino (Rusby) D.M. Johnson $\&$ N.A. Murray (ם). 
Habitat \& Ecology - In non-inundated forest or savannah forest, on clayey soil. At elevations up to $620 \mathrm{~m}$. Flowering: January, June, September, October; fruiting: September to January, April, May.

Vernacular names - Brazil: Envira cajú, Envira preta, Envireira casca rocha.

Note - Onychopetalum amazonicum is distinct from O. periquino by the lower side of the leaves which is densely covered with greyish, appressed hairs (vs glabrous).

\section{Onychopetalum periquino (Rusby) D.M. Johnson \& N.A. Murray - Fig. 9;} Plate 1f; Map 5

Onychopetalum periquino (Rusby) D. M. Johnson \& N.A. Murray (1995) 290. - Trigynaea periquino Rusby (1927) 247. - Type: White s.n. (holo NY), Bolivia, Beni, Cachuela Esperanza, 150 m, 12 March 1922.

Onychopetalum krukoffii R.E. Fr. (1937) 268, syn. nov. - Type: Krukoff 5326 (holo S; iso A, AAU, F, G, K, M, MICH, MO, NY, RB, S, U, UC, US), Brazil, Acre, mouth of Rio Macauhan, 8 August 1933.

Onychopetalum lucidum R.E. Fr. (1937) 281, f. 10k, syn. nov. - Type: Krukoff 8214 (holo NY; iso A, BM, BR, F, G, GH n.v., K, MICH, MO, NY, S, U), Brazil, Amazonas, Mun. São Paulo de Olivença, near Palmares, 60 m, 11 September to 26 October 1936.

Tree 8-30 m tall, 15-40 cm diam., sometimes with red exudate; young twigs glabrous. Leaves: petiole 4-7 $\mathrm{mm}$ long, $1.5-2.5 \mathrm{~mm}$ diam.; lamina narrowly elliptic (to narrowly obovate), slightly asymmetrical, $8-19$ by $2.5-5 \mathrm{~cm}$ (leaf index $2.6-4.4$ ), chartaceous to sometimes coriaceous, sparsely to densely verruculose, dull to sometimes shiny above, brown to pale brown, or grey above, brown to yellowish brown below, glabrous above and below, base acute, rarely obtuse, apex acuminate (acumen 5-20 mm long), secondary veins indistinct, curved, $13-17$ on either side of primary vein, raised above, angles with primary vein $40-50(-60)^{\circ}$, loop-forming at right to obtuse angles, smallest distance between loops and margin $1.5-2.5 \mathrm{~mm}$, tertiary veins indistinct, percurrent. Inflorescences on older branches, rarely among leaves, compact, to sublax distally, composed of 2-20 (or possibly more) rhipidia, sessile, axial internodes to $2 \mathrm{~mm}$ long; rhipidia 1- or 2-flowered, to 5 flowers in succession; upper bract at 1/2-3/4 from the base of the pedicel, very broadly to depressed ovate, $0.5-1 \mathrm{~mm}$ long, outer side sparsely to densely covered with appressed hairs; pedicels $8-12 \mathrm{~mm}$ long, c. $0.5 \mathrm{~mm}$ diam., fruiting pedicels $10-20 \mathrm{~mm}$ long, 2-3 mm diam., sparsely to densely covered with appressed hairs; flower buds broadly ellipsoid to ellipsoid, or broadly ovoid; sepals basally to largely connate, depressed ovate, $1-1.5$ by $1-2 \mathrm{~mm}$, outer side sparsely to densely covered with appressed hairs; petals white to greenish white in vivo, outer ones elliptic to narrowly elliptic, or ovate, 4-7 by $2.5-4 \mathrm{~mm}$, outer side sparsely to densely covered with appressed hairs, inner ones narrowly elliptic to narrowly ovate, or ovate, $3-7$ by $2-3 \mathrm{~mm}$, with an apical appendage $1-2 \mathrm{~mm}$ long, outer side glabrous except for hairy exposed part; stamens $1.5-4 \mathrm{~mm}$ long; carpels 1 or 2, c. $1 \mathrm{~mm}$ long, sparsely covered with appressed hairs to glabrous, ovules 3 or 4, lateral. Monocarps 1 or 2 , green, orange, red, to purple in vivo, brown, reddish brown, to brownish black in sicco, globose to broadly ellipsoid, $30-60$ by $20-40 \mathrm{~mm}$, glabrous, apex rounded, not apiculate, wall $0.4-2 \mathrm{~mm}$ thick, stipes absent. Seeds 2 or 3, lateral, 13-18 by 10-16 by $6-8 \mathrm{~mm}$, red, brown, or black.

Distribution - Amazonian Peru (Madre de Dios), Brazil (Acre, Amazonas, Mato Grosso, Rondônia), Bolivia (Beni, Santa Cruz). 

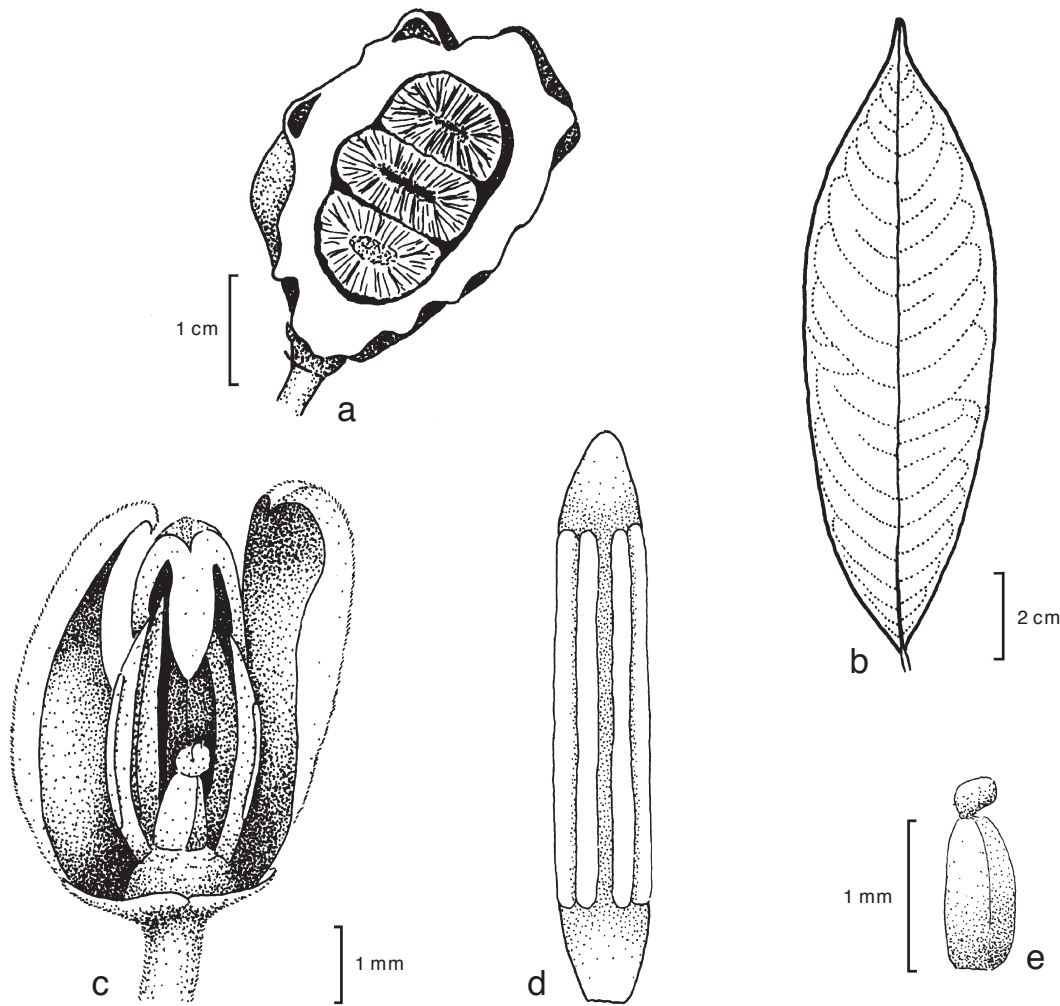

Fig. 9. Onychopetalum periquino (Rusby) D.M. Johnson \& N.A. Murray. a. Longitudinal section of monocarp; b. leaf; c. flower bud with part of petals and stamens removed; d. stamen; e. carpel (a: Peña 697; b: R. Guillén et al. 2370; c-e: Krukoff 5326). - Drawing by M. Vermeer.

Habitat \& Ecology — In non-inundated or sometimes periodically inundated forest, on sandy or clayey soil. At elevations up to 500 m. Flowering: July to October; fruiting: August to February, May.

Vernacular names - Bolivia: Cotibi, Piraquina, Xahuisi. Brazil: Envira cajú, Inuira cajú. Peru: Carahuasca, Marañon del monte, Schisohsiom.

Notes - Onychopetalum periquino can be distinguished from $O$. amazonicum by its somewhat smaller and narrower, glabrous leaves, with fewer secondary veins.

"Fruit pericarp with pulp orange like a mango" (Janovec et al. 1859 (BRIT)).

\section{UNONOPSIS - Plate 2-6; Map 6}

Unonopsis R.E. Fr. (1900) 26, t. IV, 3-8; (1937) 231. - Lectotype (selected by Hutchinson, 1923: 259): Unonopsis angustifolia (Benth.) R.E. Fr. [三 Trigynaea angustifolia Benth.] = Unonopsis guatterioides (A.DC.) R.E. Fr.

Trees or shrubs 1-30 m tall, sometimes with red exudate; leafy twigs mostly sparsely to densely covered with appressed or erect, simple hairs when young, mostly soon 
becoming glabrous. Leaves distichous, simple, entire, shortly petiolate, exstipulate; lamina mostly medium-sized to large, mostly narrowly elliptic to narrowly obovate, symmetrical or slightly asymmetrical, leaf index 1.9-6.3, chartaceous, sometimes coriaceous, when dry often covered with minute wartlike outgrowths (verruculose) on both sides, but most visibly so above, base acute, obtuse, sometimes cordate, apex acuminate, rarely acute, upper side glabrous or with some erect or appressed hairs along primary vein, lower side glabrous or sparsely to densely covered with erect or appressed, simple hairs, mainly along primary vein and secondary veins, venation brochidodromous, rarely eucamptodromous, primary vein raised above and below, secondary veins mostly distinct, straight to curved, between $6-25(-35)$ on either side of the primary vein, angles with primary vein $30-75^{\circ}$, impressed, sometimes flat to raised above, loop-forming at right to obtuse angles, smallest distance between loops and margin 1-5(-7) mm, tertiary veins mostly distinct and percurrent. Inflorescences on older branches or among leaves, rarely borne on the trunk, exceptionally terminal, compact to lax, composed mostly of $1-5$ rhipidia, in some species to 10 -more rhipidia, sessile or on a peduncle-like base; rhipidia with variable number of flowers (sometimes 15 flowers in succession or more), rarely a single flower, sympodial rachis obscure to manifest (to sometimes $10 \mathrm{~mm}$ long or much more); upper bract mostly in lower half to about the middle of the pedicel, ovate to broadly ovate or ovate-triangular, mostly between 1-3 mm long. Indument: inflorescence, including peduncles, pedicels, sympodial rachis, outer side of bracts, sepals, outer petals, and exposed outer part of inner petals densely to sparsely covered with appressed or erect, simple hairs, the inner side of bracts, sepals and petals glabrous. Flower buds globose to subglobose, or ovoid to depressed ovoid, obtuse, rarely pointed. Flowers actinomorphic, bisexual, perianth consisting of one whorl of sepals and two whorls of petals; sepals three, valvate, mostly basally connate, much smaller than the petals; petals six, valvate, cream, white, or yellow, rarely

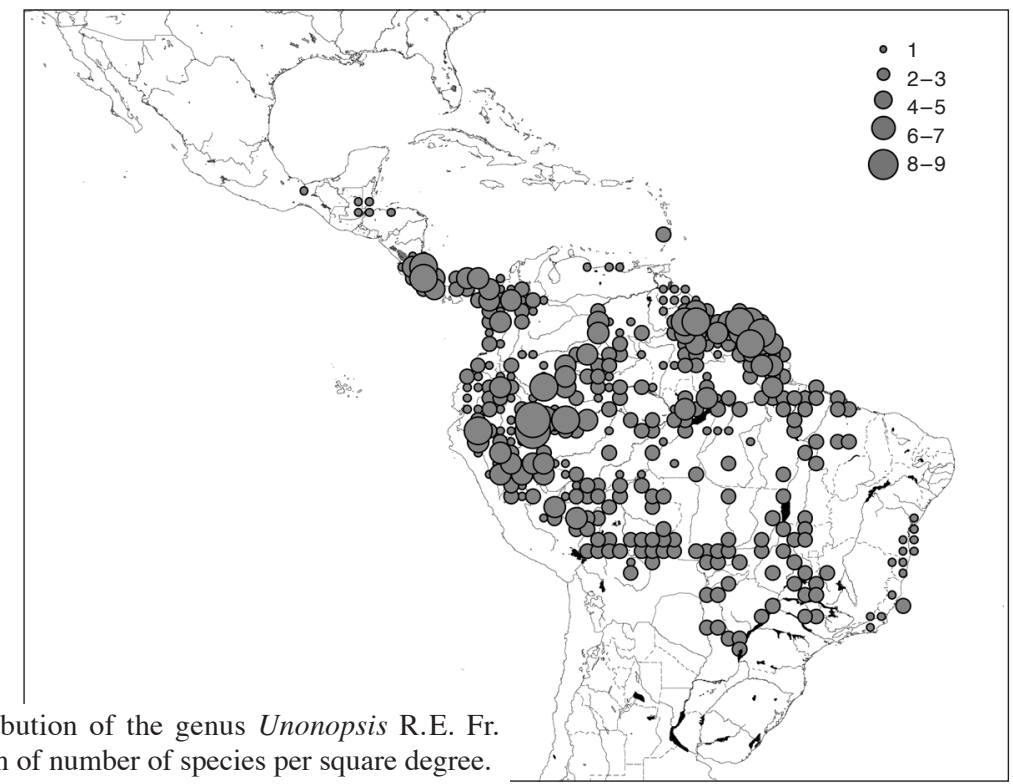

Map 6. Distribution of the genus Unonopsis R.E. Fr. with indication of number of species per square degree. 
orange, the outer ones broadly to depressed ovate, flat or slightly concave, the inner ones often broadly ovate, strongly concave; torus broadly ovoid, transversely ellipsoid, or cylindrical; stamens numerous, spirally arranged, extrorse, connective shield discoid, glabrous, sometimes papillate; carpels few to numerous, spirally arranged, free, ovary 1-locular with 1-5, basal, lateral, or rarely apical ovules, often densely covered with appressed hairs, stigma broadly ovoid or shallowly obconical, hairy or glabrous. Fruit apocarpous, composed of 1-50(-70), free monocarps, often with persistent sepals; monocarps mostly globose to ellipsoid, fleshy, green, orange, red, to black, (6-)10-45 mm diam., glabrous, sometimes covered with appressed to erect hairs, apex rounded, sometimes apiculate (apiculum 0.1-1 mm long), wall 0.1-1(-2.5) mm thick, stipes of monocarps 0-30 mm long, glabrous, sometimes covered with appressed to erect hairs. Seeds 1-6 per monocarp, basal, lateral, rarely apical, in 1 row, transversely ellipsoid to globose, glabrous, often dark brown, pitted, with a distinct canaliculate raphe completely surrounding the seed, aril absent, ruminations spiniform.

Chromosome number $-2 \mathrm{n}=18$ (Morawetz, pers. comm.).

Distribution - 48 species, occurring in Central America and tropical South America.

Habitat \& Ecology - In non-inundated forest, rarely in temporarily inundated forest. At low elevations, but a few reaching up to $2000 \mathrm{~m}$.

Note - The genus name Unonopsis is derived from the old genus name Unona L.f. (=Xylopia L.) and 'opsis' (Old Greek 'face'), because of the superficial resemblance.

\section{KEY TO THE SPECIES OF UNONOPSIS}

Not included in this key (too incomplete): $U$. silvatica.

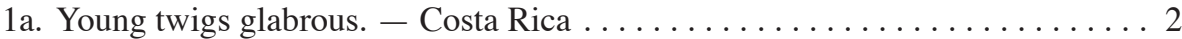

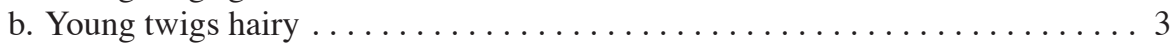

2a. Young twigs glaucous; petiole 2-4 mm long; leaf base cordate to obtuse; pedicels 7-18 mm long; monocarps 1 -seeded . . . . . . . . . . . . . .43. U. stevensii

b. Young twigs not glaucous; petiole 5-10 mm long; leaf base acute; pedicels 25-40

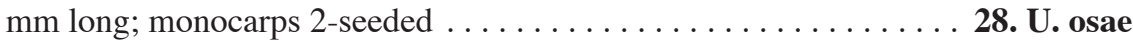

3a. Vegetative parts of the plant hirsute, with rough, brownish, erect hairs up to $3 \mathrm{~mm}$ long. - Amazonian Peru and Colombia, and adjacent Brazil . . . . . . . . . .

13. U. elegantissima

b. Vegetative parts of the plant never hirsute, hairs up to $1.5 \mathrm{~mm}$ long (usually much

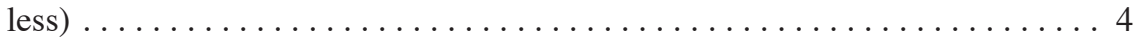

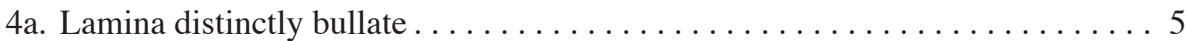

b. Lamina flat, never bullate $\ldots \ldots \ldots \ldots \ldots \ldots \ldots \ldots \ldots \ldots$

5a. Lamina $20-40$ by $7-14 \mathrm{~cm}$, base cordate, lower side densely to rather densely covered with erect hairs. - Costa Rica . . . . . . . . . 46. U. theobromifolia

b. Lamina $10-20$ by $2.5-7 \mathrm{~cm}$, base acute to obtuse, lower side sparsely covered with appressed or erect hairs . . . . . . . . . . . . . 6

6a. Lamina with 14-40 secondary veins; sepals basally connate; outer petals 5-6 mm long; monocarps 1-seeded. - Costa Rica, Panama . . . . . . . . . 6. U. bullata

b. Lamina with 8-14 secondary veins; sepals almost completely connate into a cuplike structure; outer petals 8-14 mm long; monocarps 1-4-seeded. - Amazonian Peru and Ecuador. .................. 33. U. peruviana 
7a. Monocarps resembling the head of a bird, apex acute and slightly curved; lamina with 20-25 secondary veins. - Colombia (Antioquia, Santander) 3. U. aviceps

b. Monocarps generally globose to ellipsoid, apex mostly obtuse and never curved (monocarps unknown in $U$. riedeliana); lamina with $<20$ secondary veins $\ldots 8$

8a. Monocarps mostly transversely ellipsoid (thus broader than long). - Western

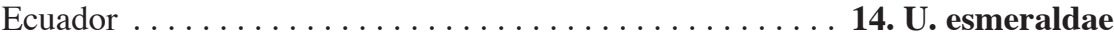

b. Monocarps very rarely broader than long . . . . . . . . . . . . . . 9

9a. Lamina elliptic; seeds $>20 \mathrm{~mm}$ long. — Panama ... . 24. U. megalosperma

b. Lamina narrowly ovate, narrowly elliptic, or rarely narrowly obovate; seeds rarely

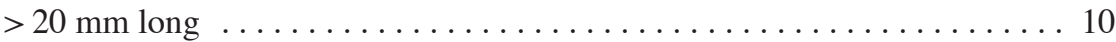

10a. Flowers appearing solitary (but see also $U$. guatterioides and $U$. longipes) . 11

b. Flowers in few- to many-flowered inflorescences, sometimes seemingly 1-flowered (but always examine the base of the inflorescence) . . . . . . . . . 14

11a. Pedicels 50-115 mm long; outer petals 13-24 mm long. - Costa Rica . . . . .

31. U. penduliflora

b. Pedicels $10-50 \mathrm{~mm}$ long; outer petals $<10 \mathrm{~mm}$ long $\ldots \ldots \ldots \ldots \ldots 12$

12a. Lamina 24-40 cm long; monocarps 10-50. - Panama . . 30. U. panamensis

b. Lamina 9-24 cm long; monocarps $3-15 \ldots \ldots \ldots \ldots \ldots \ldots \ldots$

13a. Carpels c. 10; monocarps 1-seeded, wall 0.2-0.4 mm thick. - Northwestern Colombia ....................... . . colombiana

b. Carpels > 50; monocarps 1-3-seeded, wall c. 1 mm thick. - Costa Rica . . . .

10. U. costaricensis

14a. Plant cauliflorous . . . . . . . . . . . . . . . . . . . . . 15

b. Plant flowering among leaves or on older leafless branches . . . . . . . . . 18

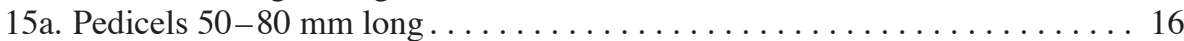

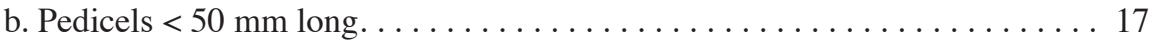

16a. Lamina $9-14$ by $3-4 \mathrm{~cm}$; monocarps $12-25$ by $12-15 \mathrm{~mm}, 1-$ or 2 -seeded.

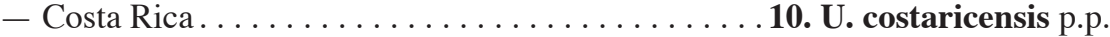

b. Lamina $12-26$ by $4-8 \mathrm{~cm}$; monocarps c. 10 by $6-10 \mathrm{~mm}$, 3- or 4 -seeded. -

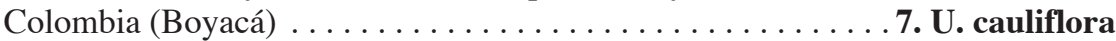

17a. Inflorescence lax, many-flowered; lamina chartaceous, secondary veins distinct, impressed above; monocarps generally more or less globose, wall 1-2 mm thick. - Venezuela and the 3 Guianas .............. 16. U. glaucopetala

b. Inflorescence compact, few-flowered; lamina mostly coriaceous, secondary veins indistinct, raised above; monocarps generally ellipsoid, wall $0.2-0.5 \mathrm{~mm}$ thick.

— Throughout the Amazon Region and the 3 Guianas . . . . . . 44. U. stipitata

18a. Secondary veins not loop-forming, or only loop-forming near the apex . . 19

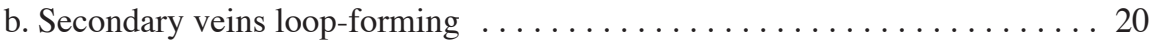

19a. Leaves $3-45$ by $7-14 \mathrm{~cm}$; secondary veins $16-20$; stipes of monocarps $2-4 \mathrm{~mm}$ long; flower buds pointed. - Amazonian Peru . . . . . . . 1. U. asterantha

b. Leaves $13-21$ by $4.5-9 \mathrm{~cm}$; secondary veins 7-11; stipes of monocarps 7-15 mm long; flower buds obtuse. - Ecuador, Peru (Amazonas, Cajamarca), at elevations of $1500-2050 \mathrm{~m} \ldots \ldots \ldots \ldots \ldots \ldots \ldots \ldots \ldots$ 26. U. monticola

20a. Leaf apex obtuse or shortly and bluntly acuminate; leaf base cordate to obtuse,

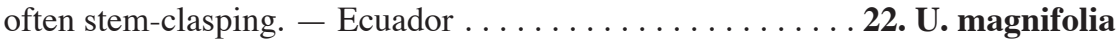

b. Leaf apex acuminate, rarely acute; leaf base acute to obtuse, less often cordate,

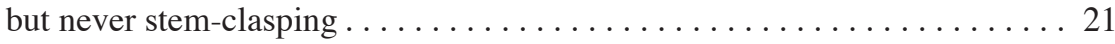




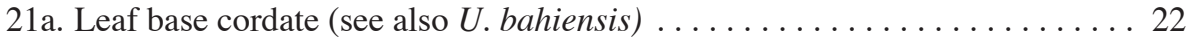

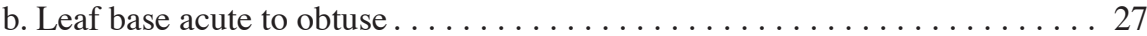

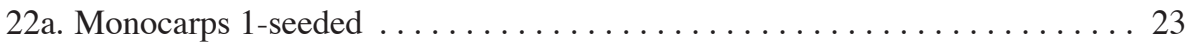

b. Monocarps several-seeded (always examine several monocarps!) . . . . . . 25

23a. Young twigs with erect hairs to $1.5 \mathrm{~mm}$ long, interspersed with much shorter hairs; monocarps $9-12$ by $6-7 \mathrm{~mm}$, stipes $4-7 \mathrm{~mm}$ long. - Brazil (Pará)

19. U. heterotricha

b. Young twigs with uniform hairs; monocarps $12 \mathrm{~mm}$ or more long, stipes of mono-

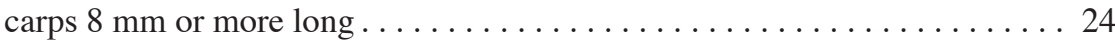

24a. Monocarps ellipsoid, shrivelled when dry; inflorescence mostly compact. Throughout the Amazon Region .............. 47. U. veneficiorum

b. Monocarps globose, never shrivelled when dry; inflorescence lax to compact. - Colombia, adjacent Panama, Ecuador (Los Ríos) . . . . . . 29. U. pacifica

25a. Stipes of monocarps 5-20 mm long; pedicels 10-30 mm long. - Costa Rica, Panama ....................... 45. U. storkii

b. Stipes of monocarps 2-4 mm long; pedicels 3-20 mm long ......... 26

26a. Carpels 30-50; inner petals $9-10$ by $7 \mathrm{~mm}$. - Colombia (Antioquia, Caldas, and (?) El Valle)

40. U. sessilicarpa

b. Carpels $<10$; inner petals $4-6$ by $4-5 \mathrm{~mm}$. - Costa Rica

46. U. theobromifolia

27a. Monocarps several-seeded (always examine several monocarps!) . . . . . 28

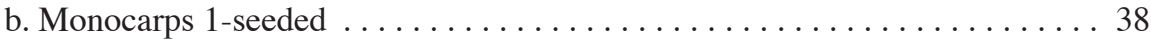

28a. Bracts 3-6 $\mathrm{mm}$ long, generally placed in the upper half of the pedicel; sepals 3-7 mm long; bark often with red exudate (Plate 2f). - Throughout the Amazon Region ...................... 42. U. spectabilis

b. Bracts $1.5-3 \mathrm{~mm}$ long, generally placed in the lower half of the pedicel; sepals 1-4 mm long; bark mostly without red exudate . . . . . . . . . . . . . 29

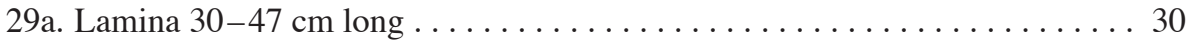

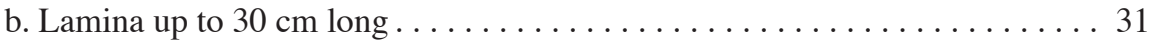

30a. Flower buds pointed; sepals almost completely connate into a cup-like structure, 1-1.5 mm long; stipes of monocarps 2-4 mm long - Amazonian Peru ......

1. U. asterantha

b. Flower buds obtuse; sepals basally connate, $1.5-3 \mathrm{~mm}$ long; stipes of monocarps 5-10 mm long. - Costa Rica, Panama ............. 45. U. storkii

31a. Stipes of monocarps 2-3 mm long. - Colombia (Antioquia, Caldas, and (?) El

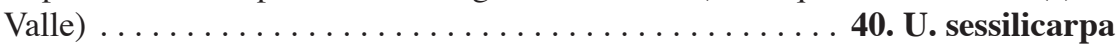

b. Stipes of monocarps $3-15 \mathrm{~mm}$ long $\ldots \ldots \ldots \ldots \ldots \ldots \ldots \ldots \ldots \ldots \ldots \ldots \ldots \ldots$

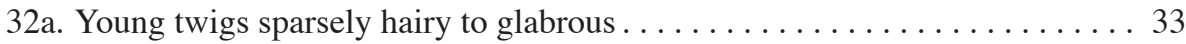

b. Young twigs densely to rather densely hairy . . . . . . . . . . . . 34

33a. Monocarps $6-25$ by $6-15 \mathrm{~mm}$, wall $0.2-0.5 \mathrm{~mm}$ thick; seeds $7-13 \mathrm{~mm}$ long. - Throughout tropical South America .......... 17. U. guatterioides

b. Monocarps c. 35 by $23 \mathrm{~mm}$, wall $1.5-3 \mathrm{~mm}$ thick; seeds c. $15 \mathrm{~mm}$ long. - Mexico (Chiapas) ......................... 25. U. mexicana

34a. Lamina coriaceous, hairs on lower side curly; angle of secondary veins with primary vein $30-45^{\circ}$. - Costa Rica, Panama . . . . . . 18. U. hammelii

b. Lamina chartaceous, hairs on lower side straight; angle of secondary veins with primary vein often much exceeding $45^{\circ} \ldots \ldots \ldots \ldots \ldots \ldots \ldots \ldots \ldots \ldots \ldots \ldots \ldots \ldots$ 
35a. Sepals almost completely connate into a cup-like structure; fruiting receptacle 8-12 mm diameter. - Amazonian Peru and Ecuador . . . . 33. U. peruviana

b. Sepals basally connate or free; fruiting receptacle $3-7 \mathrm{~mm}$ diameter. . . . . 36

36a. Inflorescence 2-5(-15)-flowered; petiole 4-15 mm long. - Panama, Colombia $\ldots \ldots \ldots \ldots \ldots \ldots \ldots \ldots \ldots \ldots \ldots \ldots \ldots \ldots \ldots \ldots \ldots \ldots$ 11. Uarienensis

b. Inflorescence mostly 1-flowered; petiole $1-7$ mm long . . . . . . . . . . 37

37a. Bracts 1-2 mm long; tertiary veins of lamina indistinct; leaf base acute to obtuse, rarely cordate. - Throughout tropical South America . . . 17. U. guatterioides

b. Bracts 2-3 mm long; tertiary veins of lamina distinct; leaf base obtuse to cordate. - Panama, Colombia (Antioquia, Chocó) ........... 20. U. longipes

38a. Petals orange, 3-5 mm long. - Brazil (Espírito Santo) . . . 2. U. aurantiaca

b. Petals green or yellow to white, (orange exceptionally in one specimen of $U$. $b a$ hiensis and $U$. veneficiorum each), 3-14 mm long (unknown in U. heterotricha,

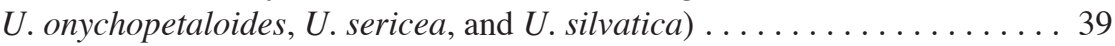

39a. Lamina with hardly visible secondary veins. - Guyana, French Guiana, Brazil

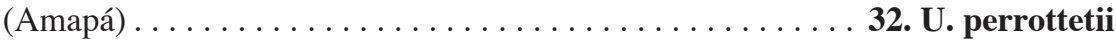

b. Lamina with distinct secondary veins . . . . . . . . . . . . . . 40

40a. Inflorescence lax and often richly branched $\ldots \ldots \ldots \ldots \ldots \ldots \ldots \ldots$

b. Inflorescence compact . . . . . . . . . . . . . . . . . 46

41a. Wall of monocarps $1-2.5 \mathrm{~mm}$ thick; outer petals $3.5-6 \mathrm{~mm}$ long . . . . . . 42

b. Wall of monocarps $0.2-0.5 \mathrm{~mm}$ thick; outer petals $4-10 \mathrm{~mm}$ long . . . . . 43

42a. Monocarps glaucous; lamina $10-18$ by $3-7 \mathrm{~cm}$. - The 3 Guianas and Amazonian

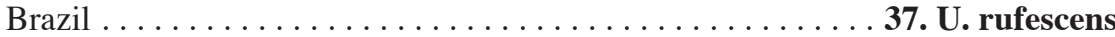

b. Monocarps not glaucous; lamina $15-45$ by $5-13 \mathrm{~cm}$. - The 3 Guianas and adjacent Venezuela ................... 16. U. glaucopetala

43a. Sepals almost completely connate into a cup-like structure; lamina acute or abruptly acuminate at the apex (acumen 1-10 mm long), secondary veins $15-18$. - Panama and throughout Colombia ............. 29. U. pacifica

b. Sepals connate at the base; lamina gradually acuminate at the apex (acumen 5-20

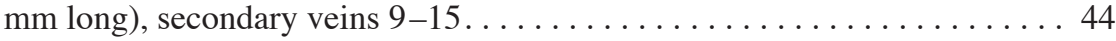

44a. Petiole 2-3 mm long; young twigs with erect hairs to $1.5 \mathrm{~mm}$ long, interspersed with short hairs; monocarps $9-12$ by $6-7 \mathrm{~mm}$. - Brazil (Pará)

19. U. heterotricha

b. Petiole 4-10 mm long; young twigs with uniform hairs; monocarps 11-20 by

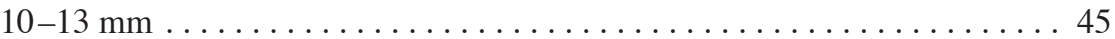

45a. Seed and ovule apical; inner petals $6-9$ by $6-10 \mathrm{~mm}$. - Throughout the Amazon Region ...................... U. floribunda

b. Seed and ovule lateral; inner petals $4-7$ by 3-6 mm. - Central America and (?)

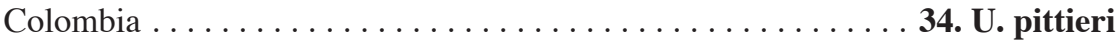

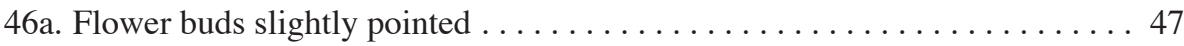

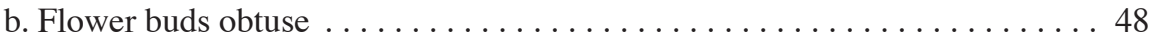

47a. Monocarps $1-5,15-25$ by $15-20 \mathrm{~mm}$, stipes $10-15 \mathrm{~mm}$ long. - Brazil (Minas Gerais $\ldots \ldots \ldots \ldots \ldots \ldots \ldots \ldots \ldots \ldots \ldots \ldots \ldots \ldots \ldots \ldots \ldots \ldots \ldots$. U. bauxitae

b. Monocarps 5-30, 13-15 by 10-12 mm, stipes 5-7 mm long. - Brazil (Espírito Santo $\ldots \ldots \ldots \ldots \ldots \ldots \ldots \ldots \ldots \ldots \ldots$ 38. U. sanctae-teresae 
48a. Lamina densely sericeous on the lower side. - Colombia (Antioquia) . . . . . .

39. U. sericea

b. Lamina sparsely hairy to glabrous on the lower side . . . . . . . . . . . . . 49

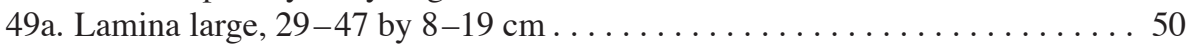

b. Lamina generally small to medium-sized, $4-30$ by $3.5-11 \mathrm{~cm} \ldots \ldots \ldots \ldots 51$

50a. Monocarps 5-20, 15-20 by $15 \mathrm{~mm}$. - Colombia (Antioquia, Bolívar, Riser-

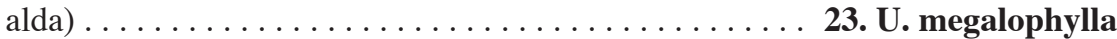

b. Monocarps 2-9, 24-29 by 32-35 mm. - Panama (Darién) and (?) Colombia

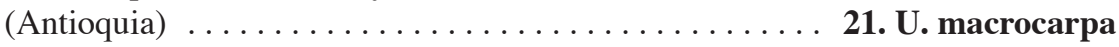

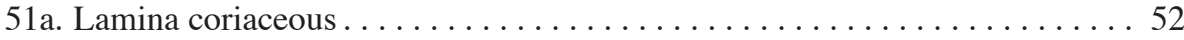

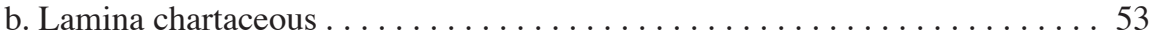

52a. Monocarps 7-35; outer petals 3-8 mm wide. - Brazil (Bahia) 4. U. bahiensis

b. Monocarps 30-100; outer petals 5-14 mm wide. - Throughout the Amazon Region and the 3 Guianas .................. 44. U. stipitata

53a. Monocarps 1-5, 25-40 mm diameter. - Western Ecuador .

27. U. onychopetaloides

b. Monocarps mostly more than 5, 13-25 mm diam. (unknown in U. riedeliana) 54

54a. Wall of monocarps 1-2.5 mm thick; stipes of monocarps 3-5 mm long. - Brazil

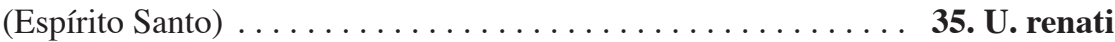

b. Wall of monocarps $0.2-0.5 \mathrm{~mm}$ thick; stipes of monocarps $4-30 \mathrm{~mm}$ long . 55

55 a. Outer petals $5-15 \mathrm{~mm}$ wide; carpels $30-\geq 100$, monocarps $10-70 \ldots \ldots$. . 56

b. Outer petals $3-8 \mathrm{~mm}$ wide; carpels $5-50$, monocarps $4-35 \ldots \ldots \ldots \ldots 57$

56a. Lamina verruculose; outer petals $10-16$ by $8-15 \mathrm{~mm}$, the outer side densely covered with silvery brown, appressed hairs. - Amazonian Brazil

12. U. duckei

b. Lamina not verruculose; outer petals $4-10$ by $5-14 \mathrm{~mm}$, the outer side densely covered with appressed and erect, brown hairs. - Throughout the Amazon Region and the 3 Guianas $\ldots \ldots \ldots \ldots \ldots \ldots \ldots \ldots \ldots \ldots \ldots \ldots \ldots \ldots \ldots \ldots$ 44. stipitata

57a. Lamina 4-17 by $1.5-4 \mathrm{~cm}$. - Brazil (Rio de Janeiro) . . . 36. U. riedeliana

b. Lamina mostly much larger, $10-30$ by $3-10 \mathrm{~cm} \ldots \ldots \ldots \ldots \ldots$

58a. Number of rhipidia 3-10; monocarps often shrivelled when dry. - Throughout

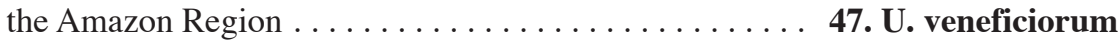

b. Number of rhipidia 1-3; monocarps never shrivelled when dry . . . . . . . 59

59a. Monocarps transversely ellipsoid to globose; number of rhipidia 1; tertiary leaf venation distinct; monocarps 4-10; seed lateral to apical, 13-16 mm long. - Northern Venezuela .................... 9. U. costanensis

b. Monocarps broadly ellipsoid to globose; number of rhipidia 1-3; tertiary leaf venation indistinct; monocarps 7-35; seed basal, 9-13 mm long. - Brazil (Bahia)

4. U. bahiensis

\section{KEY TO CENTRAL AMERICAN SPECIES OF UNONOPSIS}

1a. Young twigs glabrous. - Costa Rica $\ldots \ldots \ldots \ldots \ldots \ldots \ldots \ldots \ldots \ldots \ldots \ldots \ldots \ldots \ldots$

b. Young twigs at least hairy when young ................ 3

2a. Young twigs glaucous; petiole 2-4 mm long; leaf base cordate to obtuse; pedicels 7-18 mm long; monocarps 1 -seeded . . . . . . . . . 43. U. stevensii 
b. Young twigs not glaucous; petiole 5-10 mm long; leaf base acute; pedicels $25-40$

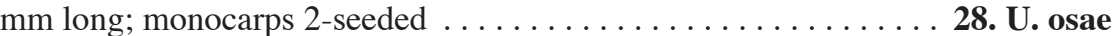

3a. Pedicels 50-115 mm long. - Costa Rica ................... 4

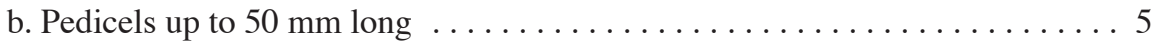

4a. Lamina $25-40$ by $7-13 \mathrm{~cm}$; petiole $7-15 \mathrm{~mm}$ long; pedicels $50-115 \mathrm{~mm}$ long 31. U. penduliflora

b. Lamina $9-14$ by $3-4 \mathrm{~cm}$; petiole $3-5 \mathrm{~mm}$ long; pedicels $50-80 \mathrm{~mm}$ long. . . . 10. U. costaricensis p.p.

5a. Young twigs sparsely covered with erect or appressed hairs, soon becoming gla-

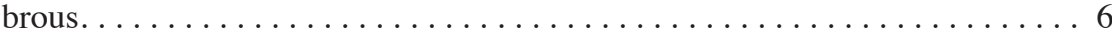

b. Young twigs densely to rather densely covered with erect or appressed hairs, finally

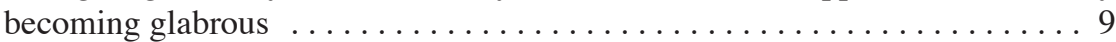

6a. Monocarps $24-33$ by $30-35 \mathrm{~mm}$; monocarps 2-9; seeds $20-27 \mathrm{~mm}$ long . . 7

b. Monocarps $10-20$ by $10-20 \mathrm{~mm}$; monocarps $1-40$; seeds $10-20 \mathrm{~mm}$ long . 8

7a. Lamina $29-42$ by $12-19 \mathrm{~cm}$; monocarps 1 -seeded; pedicels $15-35 \mathrm{~mm}$ long. - Panama and (?) Colombia ............... 21. U. macrocarpa

b. Lamina $10-15$ by $4-6 \mathrm{~cm}$; monocarps 2 - or 3-seeded; pedicels $10-15 \mathrm{~mm}$ long. - Panama ........................ 24. U. megalosperma

8a. Monocarps 1-15,1-seeded; inflorescence branched, many-flowered, often paniclelike; pedicels 3-45 mm long. - Throughout Central America . . 34. U. pittieri

b. Monocarps 10-50, 2-seeded; inflorescence generally reduced to 1 flower; pedicels 10-20 mm long. - Panama . . . . . . . . . . . . 30. U. panamensis

9a. Lamina distinctly bullate (see also under $U$. theobromifolia); carpels 4-8. - Costa

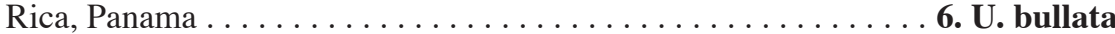

b. Lamina not bullate . . . . . . . . . . . . . . . . . . . . . . . . . 10

10a. Lower side of lamina densely to rather densely covered with mostly erect hairs

b. Lower side of lamina sparsely covered with hairs or glabrous . . . . . . . 15

11a. Base of lamina cordate . . . . . . . . . . . . . . . . . . . . . . . 12

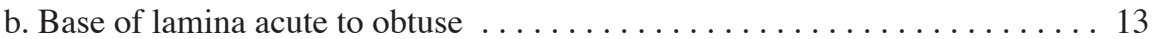

12a. Petioles 3-5 mm long; pedicels $15-50 \mathrm{~mm}$ long; stipes 6-12 $\mathrm{mm}$ long. - Panama,

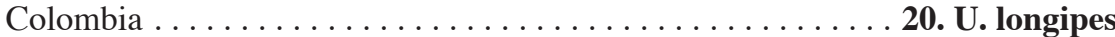

b. Petioles 5-10 mm long; pedicels 3-10 mm long; stipes 2-4 mm long. - Costa Rica ........................ . 46. U. theobromifolia

13a. Hairs on leafy twigs and lower side of lamina curly; lamina narrowly elliptic. - Costa Rica, Panama ... . . . . . . . . . . . . . 18. U. hammelii

b. Hairs on leafy twigs and lower side of lamina straight; lamina narrowly obovate

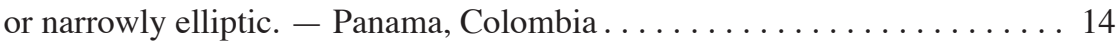

14a. Petiole 3-5 mm long; base of lamina obtuse to cordate; inflorescence 1- or 2flowered; seeds 11-13 mm long; fruit wall c. $0.2 \mathrm{~mm}$ thick . . . 20. U. longipes

b. Petiole 4-15 mm long; base of lamina acute to obtuse; inflorescence 2-5(-15)flowered; seeds $8-10 \mathrm{~mm}$ long; fruit wall c. $0.5 \mathrm{~mm}$ thick . 11. U. darienensis

15a. Monocarps c. 35 by $23 \mathrm{~mm}$. - Mexico ............ 25. U. mexicana

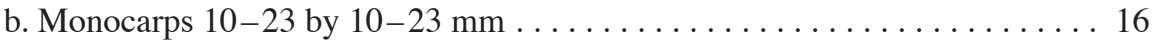

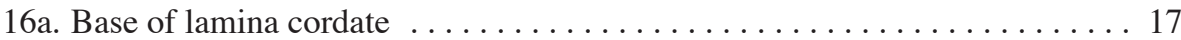

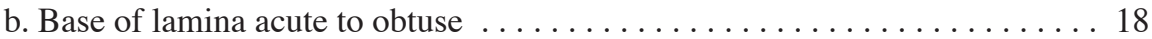


17a. Young twigs and lower side of lamina covered with curly hairs; tertiary veins of lamina distinct; inflorescence mostly compact. - Costa Rica, Panama. . . . . . . .

45. U. storkii

b. Young twigs and lower side of lamina covered with straight hairs; tertiary veins of lamina indistinct; inflorescence mostly lax. - Panama, Colombia . . . . . . . .

29. U. pacifica

18a. Monocarps 1 -seeded . . . . . . . . . . . . . . . . . . . . . . . . . 19

b. Monocarps several-seeded (always examine several) . . . . . . . . . 20

19a. Sepals almost completely connate into a cup-like structure; apex of lamina acute to abruptly acuminate (acumen 1-10 mm long). - Panama, Colombia, Ecuador

29. U. pacifica

b. Sepals connate at the base; apex of lamina gradually acuminate (acumen 5-20 mm long). - Central America, Colombia ............ 34. U. pittieri

20a. Inflorescence 1 -flowered, rarely 2 -flowered; lamina $13-16$ by $3.5-5 \mathrm{~cm}$. - Costa Rica .......................... 10. U. costaricensis

b. Inflorescence several-flowered $\ldots \ldots \ldots \ldots \ldots \ldots \ldots \ldots \ldots \ldots \ldots \ldots \ldots \ldots \ldots \ldots \ldots$

21a. Young twigs and lower side of lamina covered with straight hairs; lamina mostly

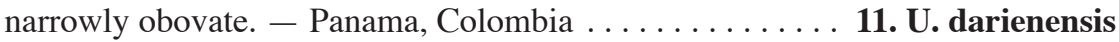

b. Young twigs and lower side of lamina covered with curly hairs. - Costa Rica,

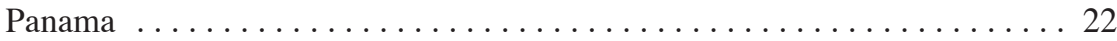

22a. Base of lamina acute to obtuse; lamina $12-22$ by $4.5-8 \mathrm{~cm}$, narrowly elliptic; seeds 1 or 2 ; outer petals $5-6 \mathrm{~mm}$ long. . . . . . . . . 18. Uammelii

b. Base of lamina obtuse to cordate; lamina $30-47$ by $9-19 \mathrm{~cm}$, narrowly elliptic to narrowly obovate; seeds $1-6$; outer petals $7-11 \mathrm{~mm}$ long . . . . 45. U. storkii

\title{
1. Unonopsis asterantha Maas \& Westra, spec. nov. - Fig. 10; Map 7
}

\begin{abstract}
Species floribus stellatis petalis patentibus acutis, foliis magnis anguste oblongo-obovatis, monocarpiis breviter stipitatis bene distincta. - Typus: Pirie et al. 108 (holo U, 3 sheets; iso HAO, HUT, USM), Peru, Amazonas, Prov. Bagua, Distr. Imaza, Putuim, Quebrada Putuim, 540 m, 26 November 2003.
\end{abstract}

Tree or shrub 2-10 m tall; young twigs and petioles densely covered with a velutinous indument of erect, brown hairs to $1 \mathrm{~mm}$ long, finally glabrous. Leaves: petiole 6-10 mm long, 3-6 mm diam.; lamina narrowly oblong-obovate, (25-)30-45 by (5-)7-14 cm (leaf index 2.9-5), coriaceous, not or sparsely verruculose, particularly along primary and secondary veins, greyish green or sometimes brown above, brown to pale brown below, glabrous on both sides except for some appressed hairs mainly along the primary vein, base obtuse to almost cordate, slightly asymmetrical, apex acuminate (acumen 15-40 mm long), rarely obtuse (Knapp \& Alcorn 7613), secondary veins distinct, curved, 16-20 on either side of primary vein, slightly raised above, angles with primary vein $50-70^{\circ}$, not or indistinctly loop-forming at obtuse angles, smallest distance between loops and margin 1-2 mm, tertiary veins distinct, percurrent. Inflorescences on older branches, sometimes among leaves, compact, composed of 2-7 rhipidia; peduncle-like base $0-3 \mathrm{~mm}$ long; rhipidia 1- or 2-flowered, to c. 5 flowers in succession; sympodial rachis to $3 \mathrm{~mm}$ long; upper bract at c. 1/4 from the base of the pedicel, depressed ovate, c. $1 \mathrm{~mm}$ long, outer side densely covered with appressed hairs; pedicels $2-15 \mathrm{~mm}$ long, 2-3 mm diam., fruiting pedicels $3-4 \mathrm{~mm}$ diam., 

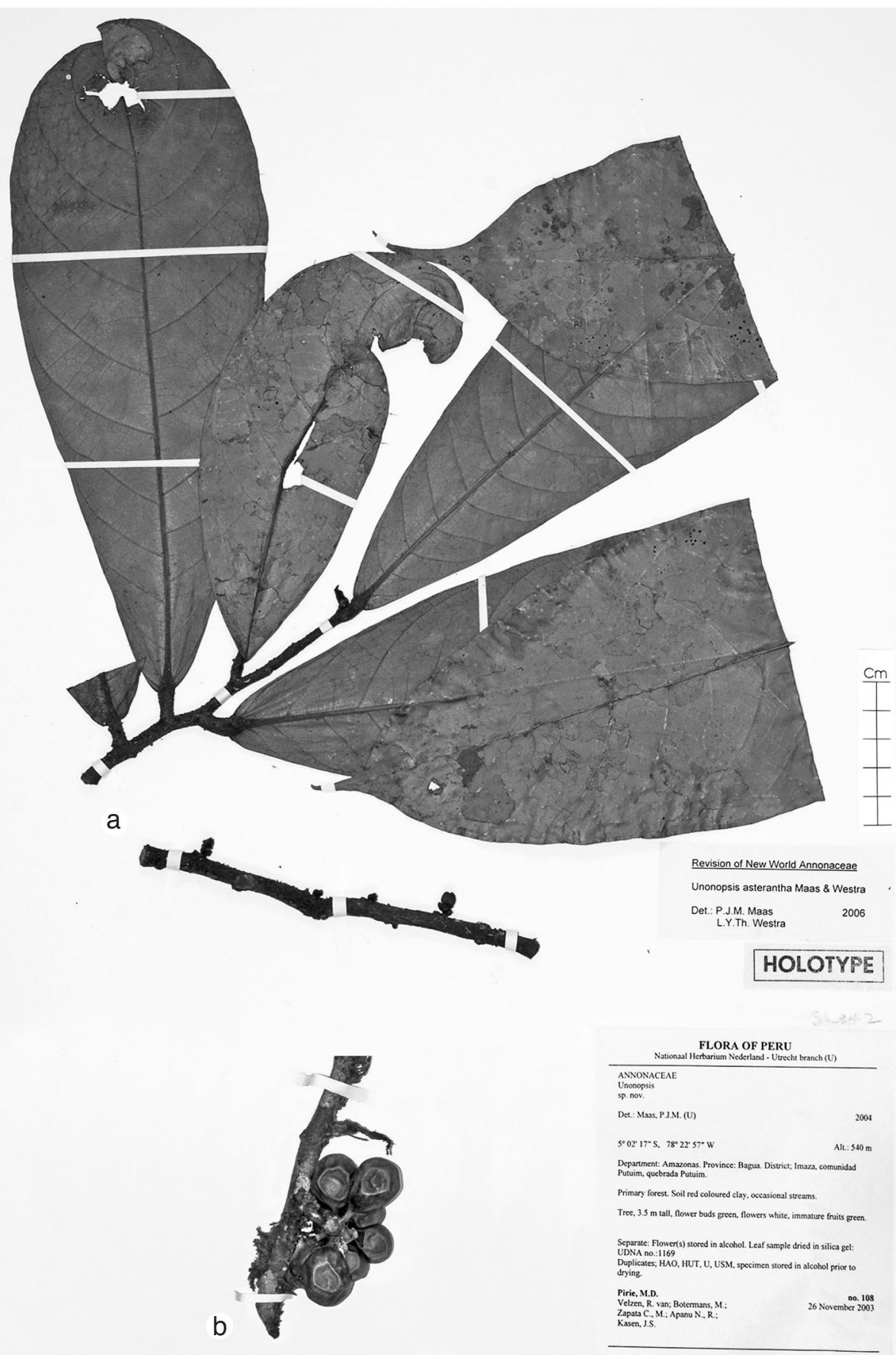

Fig. 10. Unonopsis asterantha Maas \& Westra. a. Flowering twig; b. part of fruiting twig. (a: Pirie et al. 108, holo U; b: Ancuash 92, U). 
densely to rather densely covered with appressed hairs; flower buds broadly ovoid, pointed; sepals completely connate into a cup-shaped, entire or very slightly 3-lobed structure of 4-6 mm diam., 1-1.5 mm long, outer side densely covered with appressed hairs; petals green, maturing white in vivo, outer ones ovate-triangular, flat, patent, $6\{-8\}$ by $4-6 \mathrm{~mm}$, acute, outer side densely covered with appressed hairs, inner ones ovate-triangular to broadly so, slightly concave, $5-7$ by $4-6 \mathrm{~mm}$, outer side glabrous, except for sparsely hairy exposed part; stamens c. $1.5 \mathrm{~mm}$ long, connective shield densely papillate; carpels $10-15,2-4 \mathrm{~mm}$ long, densely covered with appressed hairs, ovules 2, lateral. Monocarps 5-15, green, maturing yellow, orange, to finally red in vivo, black to brown in sicco, globose to ellipsoid, $15-20$ by $15-17 \mathrm{~mm}$, rather densely covered with appressed hairs, soon glabrous, apex rounded, asymmetrically apiculate (apiculum c. $0.1 \mathrm{~mm}$ long), wall $0.2-0.4\{-1.5\} \mathrm{mm}$ thick, stipes $2-4$ by $1.5-3 \mathrm{~mm}$; fruiting receptacle subglobose to depressed ovoid, $3-6 \mathrm{~mm}$ diam., densely to sparsely covered with appressed hairs. Seeds 1 or 2 , lateral, $11-15$ by $10-11$ by $6-8$ mm, shiny brown.

Distribution - Amazonian Peru (Amazonas, San Martín).

Habitat \& Ecology - In forest, along streams or on hillsides, on red, clayey soil. At elevations of 200-600 m. Flowering: June, November; fruiting: February, March, June, September, November, December.

Vernacular names - Peru: Achuana, Ačuána, Wáshi yéis.

Notes - Unonopsis asterantha has been so named for its starlike flowers due to the patent and pointed petals. Moreover, it is easily recognized by very large, narrowly oblong-obovate leaves to $45 \mathrm{~cm}$ long, and by very shortly stipitate monocarps.

Grández et al. 1610 (U) possibly belongs here as to foliage. Its inflorescence, however, is somewhat deviating and is briefly described as follows: inflorescence among leaves; pedicels c. $20 \mathrm{~mm}$ long, $1-1.5 \mathrm{~mm}$ diam.; upper bract at $2 / 3-3 / 4$ from the base of the pedicel, (broadly) triangular-ovate.

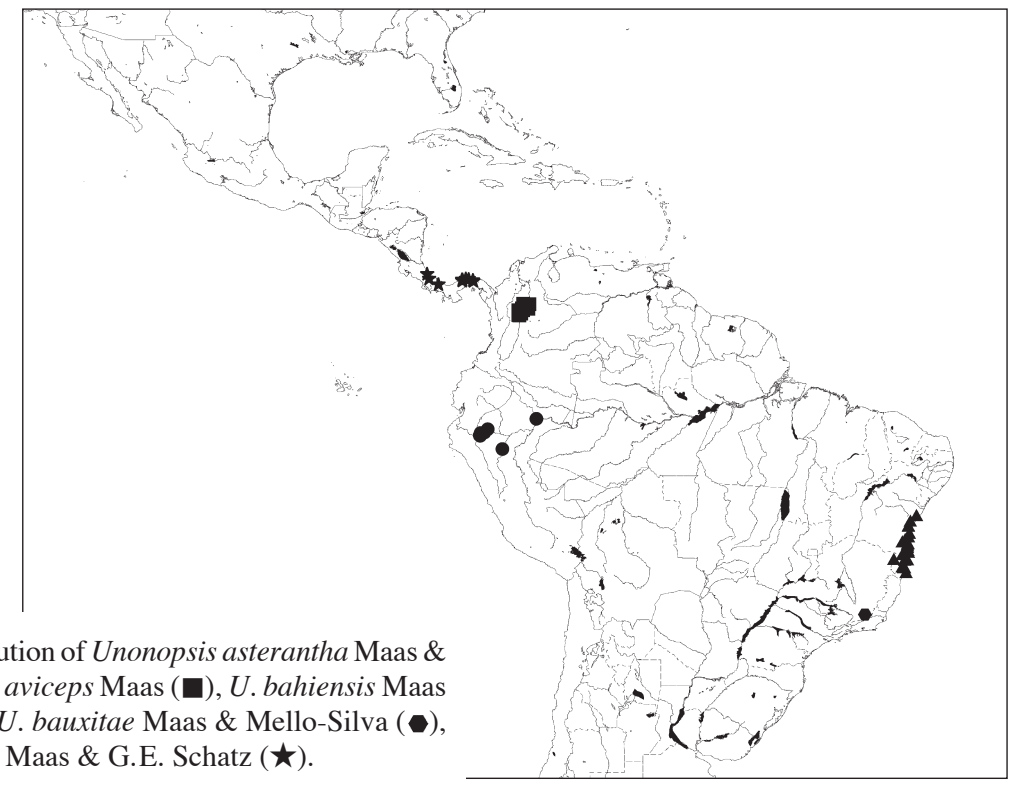

Map 7. Distribution of Unonopsis asterantha Maas \& Westra (๑), U. aviceps Maas (ם), U. bahiensis Maas \& Orava ( $\mathbf{\Delta}), U$. bauxitae Maas \& Mello-Silva ( $)$, and $U$. bullata Maas \& G.E. Schatz $(\star)$. 
2. Unonopsis aurantiaca Maas \& Westra, spec. nov. - Fig. 11; Plate 3a; Map 17

$\mathrm{Ab}$ omnibus speciebus huius generis divergens petalis minutis aurantiacis. - Typus: Maas et al. 8825 (holo U, 2 sheets; iso B, CVRD, H, K, MBML, MO, NY, SPF, WU), Brazil, Espírito Santo, Linhares, Reserva Florestal da Companhia Vale do Rio Doce, Estrada Bomba d'Agua, 2 km from Gavea, sea level, 12 February 1999.

Shrub or tree 3-4 m tall; young twigs rather densely covered with appressed hairs, soon glabrous. Leaves: petiole 3-6 mm long, 1-2 mm diam.; lamina narrowly elliptic to narrowly obovate, slightly asymmetrical, $9-24$ by $3-7 \mathrm{~cm}$ (leaf index 2.9-3.6), chartaceous, rather densely verruculose, slightly shiny and greyish green above, greyish to brownish green below, glabrous above, sparsely covered with some appressed hairs along primary vein below, base obtuse, sometimes acute, apex acuminate (acumen 5-20 mm long), secondary veins distinct, curved, 8-16 on either side of primary vein, raised above, angles with primary vein $45-65^{\circ}$, loop-forming at right to obtuse angles, smallest distance between loops and margin $1.5-4 \mathrm{~mm}$, tertiary veins distinct, percurrent. Inflorescences on older branches, compact, composed of 1-3(-4) rhipidia; peduncle-like base $0-1 \mathrm{~mm}$ long; rhipidia 2-flowered, to c. 4(-10) flowers in succession; sympodial rachis to 2(-6) mm long; upper bract at $(1 / 8-) 1 / 6-1 / 3$ from the base of the pedicel, ovate to broadly so, c. $1 \mathrm{~mm}$ long, outer side densely covered with appressed hairs; pedicels $4-8 \mathrm{~mm}$ long, $1\{-1.5\} \mathrm{mm}$ diam., fruiting pedicels to $12 \mathrm{~mm}$ long, to $2 \mathrm{~mm}$ diam., densely covered with appressed and erect hairs; flower buds ovoid; sepals basally connate, very broadly to shallowly ovate-triangular, 1-1.5 by $1.5-2 \mathrm{~mm}$, outer side densely covered with appressed hairs; petals orange, young ones somewhat greenish at the outer and inner side in vivo, outer ones ovate, concave, $4-5\{-7\}$ by $3\{-5\} \mathrm{mm}$, outer side rather densely covered with appressed hairs, inner ones obovate, strongly concave, $3-4\{-6\}$ by $3\{-4\} \mathrm{mm}$, base distinctly narrowed, apex slightly apiculate, outer side glabrous except for hairy exposed part; stamens c. 1 mm long, connective shield glabrous; carpels 15-20, c. $1 \mathrm{~mm}$ long, densely covered with appressed yellowish brown hairs, ovule 1, basal. Monocarps 10-13, green in vivo when young, brown in sicco, broadly ellipsoid to globose, 7-14 by $6-12 \mathrm{~mm}$, rather densely to sparsely covered with appressed hairs to finally glabrous, apex rounded, asymmetrically apiculate (apiculum $<0.1 \mathrm{~mm}$ long), wall $0.2-0.3\{-1\} \mathrm{mm}$ thick, stipes $8-15$ by $1-1.5 \mathrm{~mm}$; fruiting receptacle globose to broadly ovoid, $3-5 \mathrm{~mm}$ diam., rather densely covered with appressed and erect hairs. Seed 1 , basal, 7-11 by $8-11$ by 6-9 mm, reddish brown.

Distribution - Brazil (Espírito Santo).

Habitat \& Ecology - In mussununga forest. At sea level. Flowering and fruiting: January, February.

Vernacular name - Brazil: Pindaíba da mussununga.

Note - Unonopsis aurantiaca is unique within the genus because of the orange, tiny petals. It is only known from one locality in the Brazilian state of Espírito Santo. Unonopsis renati is another endemic of the same locality, see also notes under that species.

Other specimen studied:

BRAZIL. Espírito Santo: Linhares, Reserva Florestal da Companhia Vale do Rio Doce, Estrada Bomba d'Agua, Farias 351 (CVRD, U). 


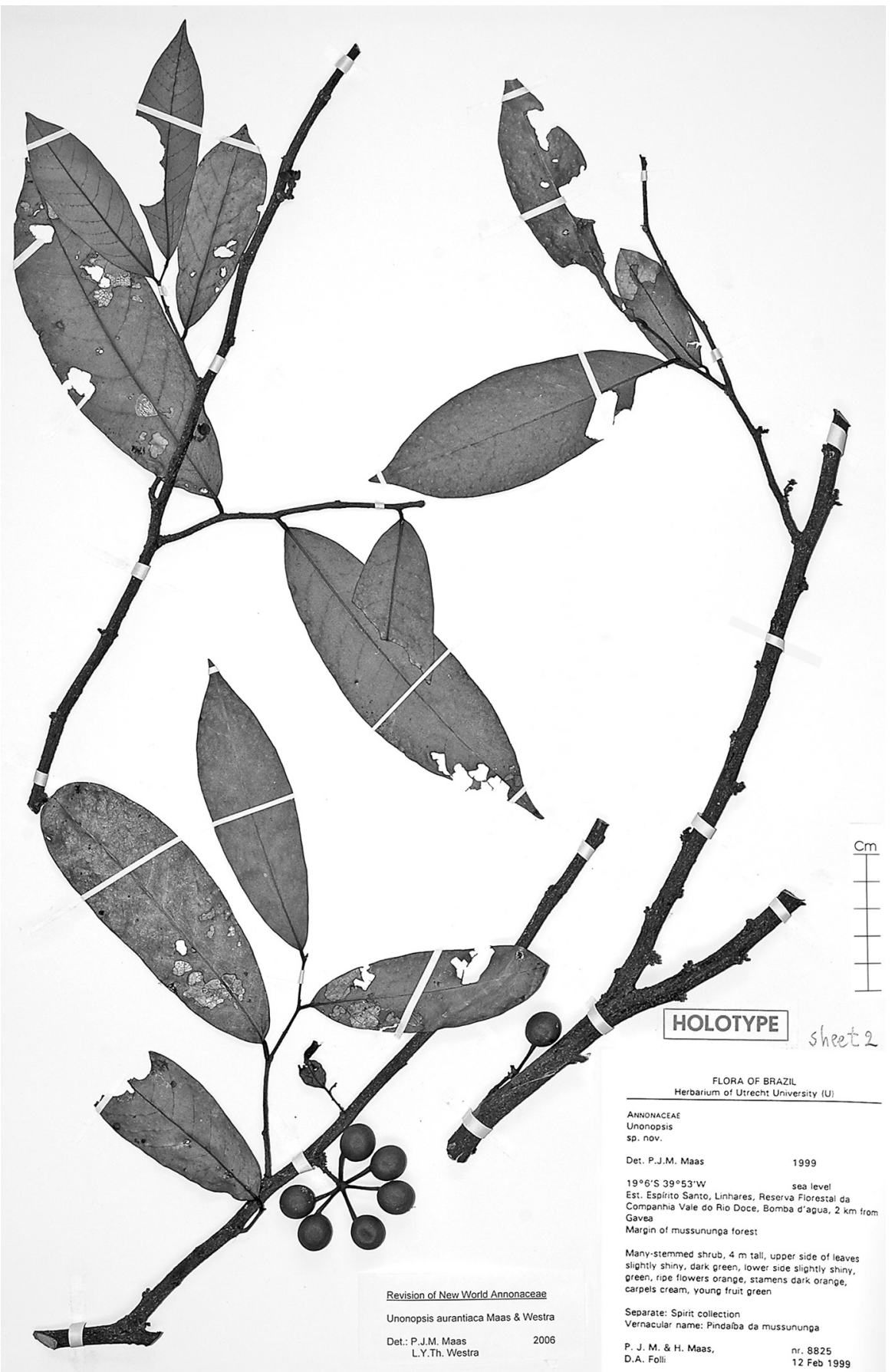

Fig. 11. Unonopsis aurantiaca Maas \& Westra. Flowering and fruiting twigs (Maas et al. 8825, holo part 2, U). 


\section{Unonopsis aviceps Maas - Map 7}

Unonopsis aviceps Maas in Maas et al. (1986) 272, f. 17, 18. - Type: Rentería A. et al. 2181 (holo JAUM), Colombia, Santander, bridge over Río Sogamoso, carretera El Pedral, 100-200 m, 30 January 1980.

Tree 5-15 $\mathrm{m}$ tall, 5-10 $\mathrm{cm}$ diam.; young twigs densely covered with a velutinous indument of appressed and erect, reddish brown hairs, soon glabrous. Leaves: petiole 6-12 $\mathrm{mm}$ long, 5-6 $\mathrm{mm}$ diam.; lamina generally narrowly elliptic to narrowly obovate, $35-55$ by $12-22 \mathrm{~cm}$ (leaf index $2.1-3.6$ ), chartaceous, not verruculose, greyish brown to greyish green above, often brown, or pale green below, primary vein sparsely covered with appressed hairs above and below, otherwise glabrous, base obtuse to slightly cordate, apex acuminate (acumen $5-10 \mathrm{~mm}$ long), secondary veins distinct, curved to straight, 20-25(-30) on either side of primary vein, impressed above, angles with primary vein $50-70^{\circ}$, loop-forming at right to obtuse angles, smallest distance between loops and margin 3-4 mm, tertiary veins distinct, percurrent. Inflorescences among leaves, sometimes on older branches, compact or sublax, composed of (1-)3-4 rhipidia; peduncle-like base $0-3 \mathrm{~mm}$ long; axial internodes $<1(-2) \mathrm{mm}$ long; rhipidia 1-3-flowered, to 15 (-20) flowers in succession; sympodial rachis to $10(-25) \mathrm{mm}$ long; upper bract at $1 / 2-1 / 3$ from the base of the pedicel, broadly triangular to semicircular, $1-1.5 \mathrm{~mm}$ long, outer side densely covered with appressed and erect brown hairs; pedicels $15-20 \mathrm{~mm}$ long, $1.5 \mathrm{~mm}$ diam., fruiting pedicels $2-3 \mathrm{~mm}$ diam., densely covered with appressed and erect brown hairs; flower buds depressed globose; sepals connate for over $1 / 2$ of their length, shallowly ovate-triangular, $1.5-2.5$ by $3-4 \mathrm{~mm}$, outer side densely covered with appressed and erect brown hairs; petals green to yellow in vivo, outer ones ovate, slightly concave, $7-10$ by $5-7 \mathrm{~mm}$, outer side densely covered with appressed and erect brown hairs, inner ones ovate, strongly concave, $5-7$ by $3-5 \mathrm{~mm}$, outer side subglabrous except for hairy exposed part; stamens $1-2$ $\mathrm{mm}$ long, connective shield glabrous; carpels c. 25, densely covered with appressed white hairs, ovule 1, basal. Monocarps 2-25, green, maturing red to black in vivo, brown in sicco, ovoid to obpyriform, $15-20$ by $10-12 \mathrm{~mm}$, sparsely to rather densely covered with erect and appressed brown hairs, apex slightly curved, acute, sometimes apiculate (apiculum c. $1 \mathrm{~mm}$ long), wall $0.2-0.5 \mathrm{~mm}$ thick, stipes $3-5$ by $1.5-3 \mathrm{~mm}$; fruiting receptacle depressed ovoid to transversely ellipsoid, $3.5-7.5 \mathrm{~mm}$ diam., densely covered with erect and appressed brown hairs. Seed $1,10-13$ by $7-10$ by $6-7 \mathrm{~mm}$, pale brown to brown.

Distribution - Colombia (Antioquia, Santander).

Habitat \& Ecology - In non-inundated forest. At elevations of 100-1000(-1200) m. Flowering: January, February, July to October; fruiting: July to March.

Vernacular name - Colombia: Mulato.

Note - A remarkable feature of $U$. aviceps are the monocarps resembling the head of a small bird (hence the epithet). The seed position was mentioned as 'apical' in the original description, but we could not verify this. Further study is needed here. Unonopsis aviceps is also distinct by leaves with a relatively high number of secondary veins. 
4. Unonopsis bahiensis Maas \& Orava, spec. nov. - Fig. 12, 13; Map 7

Unonopsis stipitatae valde affinis, sed ab ea differt carpellis pro ratione paucioribus, monocarpiis fere globosis, petalis exterioribus angustioribus. - Typus: Lewis et al. 1173 (holo CEPEC; iso K, U), Brazil, Bahia, Mun. Ilhéus, Olivença-Vila Brasil Road, 6 km W of Olivença, 8 February 1982.

Tree or shrub 1.5-10(-25) $\mathrm{m}$ tall, 1-15 cm diam.; young twigs rather densely covered with appressed and erect hairs, soon glabrous. Leaves: petiole $3-8 \mathrm{~mm}$ long, 2-3 $\mathrm{mm}$ diam.; lamina narrowly elliptic to narrowly obovate, sometimes asymmetrical, 13-30 by $3-9 \mathrm{~cm}$ (leaf index 2.9-6), mostly coriaceous, rather densely to densely verruculose,

Fig. 12. Unonopsis bahiensis Maas \& Orava. a. Leafy twig; b. parts of older flowering twig; c. parts of older fruiting twig; d. seed (all: Kallunki \& Pirani 468, NY). - Drawing by H. Rypkema.

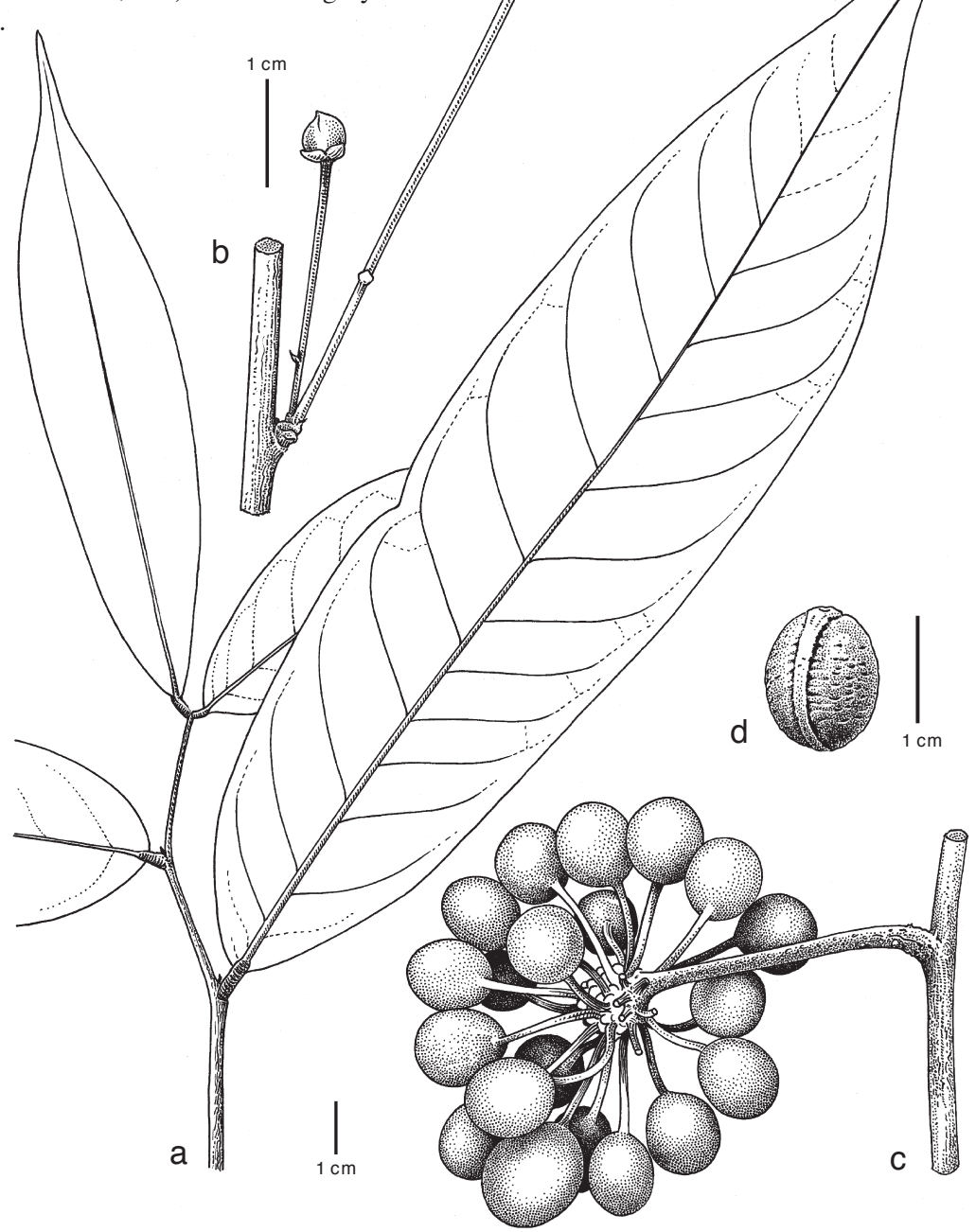


shiny or dull above, usually greyish green above, greyish to reddish brown below, glabrous above, sparsely to rather densely covered with appressed hairs along primary and secondary veins below, base obtuse, sometimes acute or cordate, apex acuminate (acumen 5-20 mm long), secondary veins distinct, curved, 10-19 on either side of primary vein, raised, sometimes flat or even slightly impressed above, angles with primary vein $40-65^{\circ}$, loop-forming at right to obtuse angles, smallest distance between loops and margin 1-4 mm, tertiary veins indistinct, weakly percurrent. Inflorescences among leaves or on older branches, compact, composed of 1-3 rhipidia; pedunclelike base $0-2(-4) \mathrm{mm}$ long; rhipidia 1- or 2-flowered, to c. 10 flowers in succession;

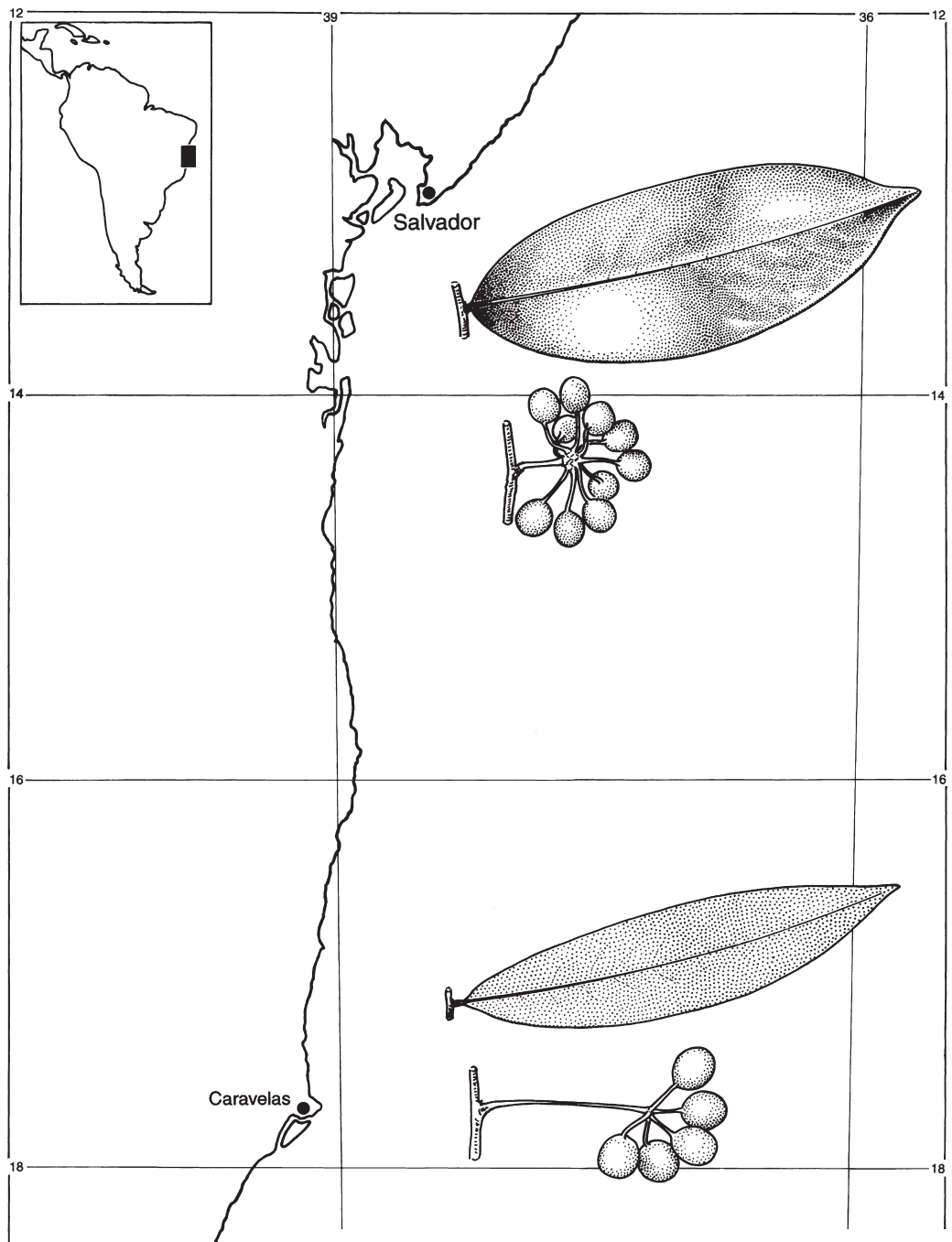

Fig. 13. Unonopsis bahiensis Maas \& Orava. Map showing regional differences in leaf shape and pedicel length. - Drawing by H. Rypkema. 
sympodial rachis to $7 \mathrm{~mm}$ long; upper bract at $1 / 8-1 / 4$ from the base of the pedicel, ovate to broadly ovate, $0.5-1.5 \mathrm{~mm}$ long, outer side rather densely to densely covered with appressed to erect hairs; pedicels $5-75 \mathrm{~mm}$ long, $0.5-1.5 \mathrm{~mm}$ diam., fruiting pedicels $1.5-4 \mathrm{~mm}$ diam., rather densely covered with appressed to erect hairs; flower buds very broadly ovoid; sepals free or basally connate, broadly to depressed ovate, $1-2.5$ by $1-3 \mathrm{~mm}$, outer side rather densely to densely covered with appressed hairs; petals green, maturing creamy yellow (orange in one collection) in vivo, outer ones broadly ovate, flat, $3-8$ by $3-8 \mathrm{~mm}$, outer side rather densely covered with appressed hairs, inner ones ovate, concave, $4-8$ by $3-6 \mathrm{~mm}$, outer side glabrous except for hairy exposed part; stamens c. $1 \mathrm{~mm}$ long, connective shield densely papillate; carpels 15-20, c. $1 \mathrm{~mm}$ long, densely covered with appressed hairs, ovule 1, basal. Monocarps 7-35, yellowish orange to red in vivo, (reddish) brown in sicco, broadly ellipsoid to globose, $10-20$ by $10-16 \mathrm{~mm}$, sparsely covered with appressed hairs to finally glabrous, apex rounded, asymmetrically apiculate or not (apiculum $0.1-0.3 \mathrm{~mm}$ long), wall $0.2-0.5$ $\mathrm{mm}$ thick, stipes $10-30$ by $1-2 \mathrm{~mm}$; fruiting receptacle globose or broadly to depressed ovoid, 3-10 mm diam., densely covered with appressed and erect hairs. Seeds 1 (or 2), basal, $9-13$ by $9-13$ by $6-12 \mathrm{~mm}$, reddish brown.

Distribution - Brazil (Bahia).

Habitat \& Ecology - In coastal rain forest or in restinga forest, on sandy to clayey soil. At elevations up to 120(-650) m. Flowering and fruiting: throughout the year.

Vernacular names - Brazil: Pindaíba, Pindaíba preta.

Notes - Unonopsis bahiensis can often be recognized by coriaceous leaves with mostly raised secondary veins above (not impressed as in most species). A further characteristic are the broadly ellipsoid to globose, 1 -seeded, and long-stipitate monocarps. It resembles $U$. stipitata, an Amazonian species, and has been confused with it (Maas et al., 1988: 266). It differs from the latter by a lower number of carpels on average (15-20 vs 30-100), the globose or almost globose monocarps (vs ellipsoid), and narrower outer petals ( $3-8$ vs $5-16 \mathrm{~mm}$ wide).

In $U$. bahiensis there are two extremes with regard to pedicel and leaf characteristics. Specimens of northern origin (mainly collected $\mathrm{N}$ of $16^{\circ} 00^{\prime} \mathrm{S}$ ) have comparatively short and stout pedicels (especially in fruiting stage), and often larger (and relatively broader), thicker, and frequently shinier leaves. Specimens from the south (collected S of $16^{\circ} 00^{\prime} \mathrm{S}$ ) have conspicuously long pedicels, and often more chartaceous, smaller, and narrower leaves (Fig. 13). However, intermediates both in leaf characteristics and pedicel length exist. All forms have in common, among others, the presence of both erect and appressed hairs on young twigs, and similar flowers and monocarps, both as to size and shape, suggestive of one species rather than two different species. Especially the northern forms of $U$. bahiensis quite resemble $U$. stipitata.

Selection of other specimens (39) examined:

BRAZIL. Bahia: Mun. Uruçuca, Distr. Serra Grande, Serra Grande-Ilhéus Rd., 3 km from Distrito, Amorim et al. 357 (CEPEC, NY); Mun. Una, Reserva Biológica do Mico-leão (IBAMA), entrance at km 46 of Ilhéus-Una Rd., Amorim et al. 1885 (CEPEC, U); Mun. Itabuna, $10 \mathrm{~km} \mathrm{~S} \mathrm{of} \mathrm{Pontal} \mathrm{(Ilhéus),}$ path to Olivença, 50 m, Arbo et al. 5571 (MO, U); Mun. Porto Seguro, Reserva Florestal da Brasil de Holanda Industrias S.A., entrance at km 22 of Eunapolis-Porto Seguro Rd., $9.5 \mathrm{~km}$ from entrance, Carvalho et al. 4472 (CEPEC, U); Mun. Canavieiras, km 21 of Canavieiras-Una Rd., road to Campo 
Lúcio, Hage \& Dos Santos 881 (CEPEC, U); Mun. Prado, BA 001 Hwy., 45 km N of Alcobaça, 25-75 m, Mori et al. 9727 (CEPEC, NY, U); Mun. Sta. Cruz de Cabrália, Estação Ecológica do PauBrasil (ESPAB), close to $16 \mathrm{~km} \mathrm{~W}$ of Porto Seguro, $120 \mathrm{~m}$, Mori et al. 9766 (CEPEC, K, NY, U); Mun. Belmonte, branch of Rio Ubu, at km 30 of Belmonte-Itapebi Rd., L.A.M. Silva \& Hage 615 (CEPEC, U); Mun. Valença, km 9 of Valença-Guaibim Rd., L.A.M. Silva et al. 1041 (CEPEC, U); Mun. Ilhéus, Barra do Manguinho, $\mathrm{km} 10$ of Pontal-Olivença Rd., $3 \mathrm{~km}$ E of road, L.A.M. Silva et al. 1392 (CEPEC, U); Mun. Cairu, km 4 of Cairu-Nilo Peçanha Rd., L.A.M. Silva \& Dos Santos 1940 (CEPEC, NY, U); Mun. Ilhéus, Olivença-Maruim Rd., $6.1 \mathrm{~km}$ W of Olivença, W.W. Thomas et al. 9071 (CEPEC, MO, NY, U, US).

\section{Unonopsis bauxitae Maas, Westra \& Mello-Silva - Map 7}

Unonopsis bauxitae Maas, Westra \& Mello-Silva in Lobão et al. (2006) 143, f. 3a-f. - Type: Castro et al. 745 (holo SPF, 3 sheets; iso BHCB, CESJ, 2 sheets, K, NY, RB, U), Brazil, Minas Gerais, Descoberto, Reserva Biológica da Represa do Grama, 350 m, 9 December 2001.

Tree 7-17 m tall; young twigs sparsely covered with appressed hairs, soon glabrous. Leaves: petiole 3-7 mm long, 2-3 mm diam.; lamina narrowly elliptic, symmetrical to slightly asymmetrical, 14-19 by 4-6 cm (leaf index 3-3.8), subcoriaceous, rather densely to sparsely verruculose, pale brown to brown and somewhat shiny above, brown to greenish brown below, glabrous above, sparsely covered with appressed hairs along primary vein to glabrous below, base acute, apex acuminate (acumen 5-25 mm long), sometimes acute, secondary veins distinct, curved, 10-15 on either side of primary vein, slightly raised above, angles with primary vein $50-60^{\circ}$, loop-forming at almost right angles, smallest distance between loops and margin $2-3 \mathrm{~mm}$, tertiary veins indistinct, more or less percurrent. Inflorescences on older branches, compact, composed of 2-5(-7) rhipidia; peduncle-like base 0-2 $\mathrm{mm}$ long; rhipidia 1-3-flowered, to c. 8 flowers in succession; sympodial rachis to $7 \mathrm{~mm}$ long; upper bract at 1/8-1/3 from the base of the pedicel, broadly to depressed ovate, 1-2 mm long, outer side densely covered with appressed golden brown hairs; pedicels 10-25 mm long, 1-1.5 mm diam., fruiting pedicels to $30 \mathrm{~mm}$ long, to $2 \mathrm{~mm}$ diam., densely covered with appressed golden brown hairs; flower buds ovoid to very broadly ovoid, pointed to slightly apiculate; sepals basally connate, shallowly ovate-triangular, $1-1.5$ by $3 \mathrm{~mm}$, outer side densely covered with appressed golden brown hairs; petals green when young in vivo, outer ones ovate, flat, $8-14$ by $5-10 \mathrm{~mm}$, outer side densely covered with appressed golden brown hairs, inner ones broadly ovate, strongly concave, $6-9$ by $4-8 \mathrm{~mm}$, outer side glabrous except for hairy exposed part; stamens c. $1 \mathrm{~mm}$ long, margins of connective shield papillate; carpels 25-50, 1-2 mm long, densely covered with appressed and erect golden brown hairs, ovule 1, basal. Monocarps 1-5, green when young in vivo, brownish black in sicco, ellipsoid to obovoid, $15-25$ by $15-20 \mathrm{~mm}$, rather densely to sparsely covered with appressed and erect golden brown hairs, apex rounded, asymmetrically apiculate (apiculum $<0.5 \mathrm{~mm}$ long), wall c. $0.5 \mathrm{~mm}$ thick, stipes $10-15$ by $2 \mathrm{~mm}$; fruiting receptacle very broadly to depressed ovoid, $2-4$ by $3-5 \mathrm{~mm}$, densely covered with appressed golden brown hairs. Seed not seen.

Distribution - Brazil (Minas Gerais).

Habitat \& Ecology - In semideciduous forest, on bauxite soil. At an elevation of c. 350 m. Flowering: November, December; fruiting: December. 
Notes - Unonopsis bauxitae closely resembles $U$. riedeliana, a species known from only 3 collections from the Rio de Janeiro region. Unonopsis bauxitae differs, however, by thicker and larger leaves (14-19 by $4-6$ vs $4-17$ by $1.5-4 \mathrm{~cm}$ ) and by pointed instead of obtuse flower buds.

For comparison with U. sanctae-teresae, from the Brazilian state of Espírito Santo, see under that species.

Other specimen studied:

BRAZIL. Minas Gerais: Descoberto, Reserva Biológica da Represa do Grama, Forzza et al. 2222 (CESJ, MO, RB, SPF, U).

6. Unonopsis bullata Maas \& G.E. Schatz, spec. nov. - Fig. 14; Plate 3b, c; Map 7

Species foliis manifeste bullatis distinctissima. - Typus: Maas et al. 9560 (holo U, 2 sheets; iso INB, NY, PMA, SCZ), Panama, Colón, Parque Nacional San Lorenzo, road to Sherman crane, $150 \mathrm{~m}, 7$ June 2004.

Tree 2-15 m tall, 4-12 cm diam.; young twigs densely covered with erect hairs, soon glabrous. Leaves: petiole 2-5 mm long, 1-2 mm diam.; lamina narrowly elliptic, sometimes narrowly obovate, $10-20(-25)$ by $2.5-6 \mathrm{~cm}$ (leaf index 2.4-5.2), chartaceous, bullate, densely to rather densely verruculose, often particularly along primary and secondary veins, brown, sometimes greyish green above, brown to greyish green below, primary vein often densely covered with erect hairs, otherwise glabrous above, sparsely covered with appressed and erect hairs along primary and secondary veins below, base obtuse to acute, apex acuminate (acumen 5-20 mm long), secondary veins distinct, curved, 14-20 on either side of primary vein, strongly impressed above, angles with primary vein $55-60^{\circ}$, loop-forming at obtuse angles, smallest distance between loops and margin 1-3 mm, tertiary veins distinct, slightly percurrent. Inflorescences among leaves or on older branches, usually a single flower on a short axis or sometimes with a second flower from the axil of an axial bract, axial internodes 1-4 mm long; upper bract at c. 1/3 from the base of the pedicel, deltate, c. $1 \mathrm{~mm}$ long, outer side rather densely covered with appressed hairs; pedicels including inflorescence axis $8-20 \mathrm{~mm}$ long, c. $1 \mathrm{~mm}$ diam., fruiting pedicels including inflorescence axis $35-45 \mathrm{~mm}$ long, 1.5-2 mm diam., rather densely covered with appressed hairs; flower buds depressed ovoid; sepals basally connate, shallowly ovate-triangular, c. 1 by $2 \mathrm{~mm}$, outer side densely covered with appressed hairs; petals white in vivo, outer ones broadly ovate, concave, $5-6$ by $4-6 \mathrm{~mm}$, outer side densely to rather densely covered with appressed hairs, inner ones broadly ovate, concave, $3\{-5\}$ by $3\{-5\} \mathrm{mm}$, outer side glabrous except for hairy exposed part; stamens 1-1.5 mm long, connective shield glabrous; carpels 4-8, c. $2 \mathrm{~mm}$ long, rather densely covered with appressed hairs, ovule 1, basal. Monocarps (1-)5-15, green, maturing black to purple in vivo, pale brown in sicco, globose, 11-20 mm diam., sparsely covered with appressed hairs when young, soon glabrous, apex rounded, not apiculate, wall c. $0.2 \mathrm{~mm}$ thick, stipes $6-15$ by $1-2 \mathrm{~mm}$; fruiting receptacle ovoid to broadly so, $3-6$ by $3-5 \mathrm{~mm}$, rather densely to sparsely covered with appressed hairs. Seed 1 , lateral, $10-13$ by $9-11$ by $5-8 \mathrm{~mm}$, pale or dark brown.

Distribution - Costa Rica (Limón) and Panama.

Habitat \& Ecology - In non-inundated forest. At elevations of 0-500 m. Flowering: May, June, August, December; fruiting: throughout the year. 


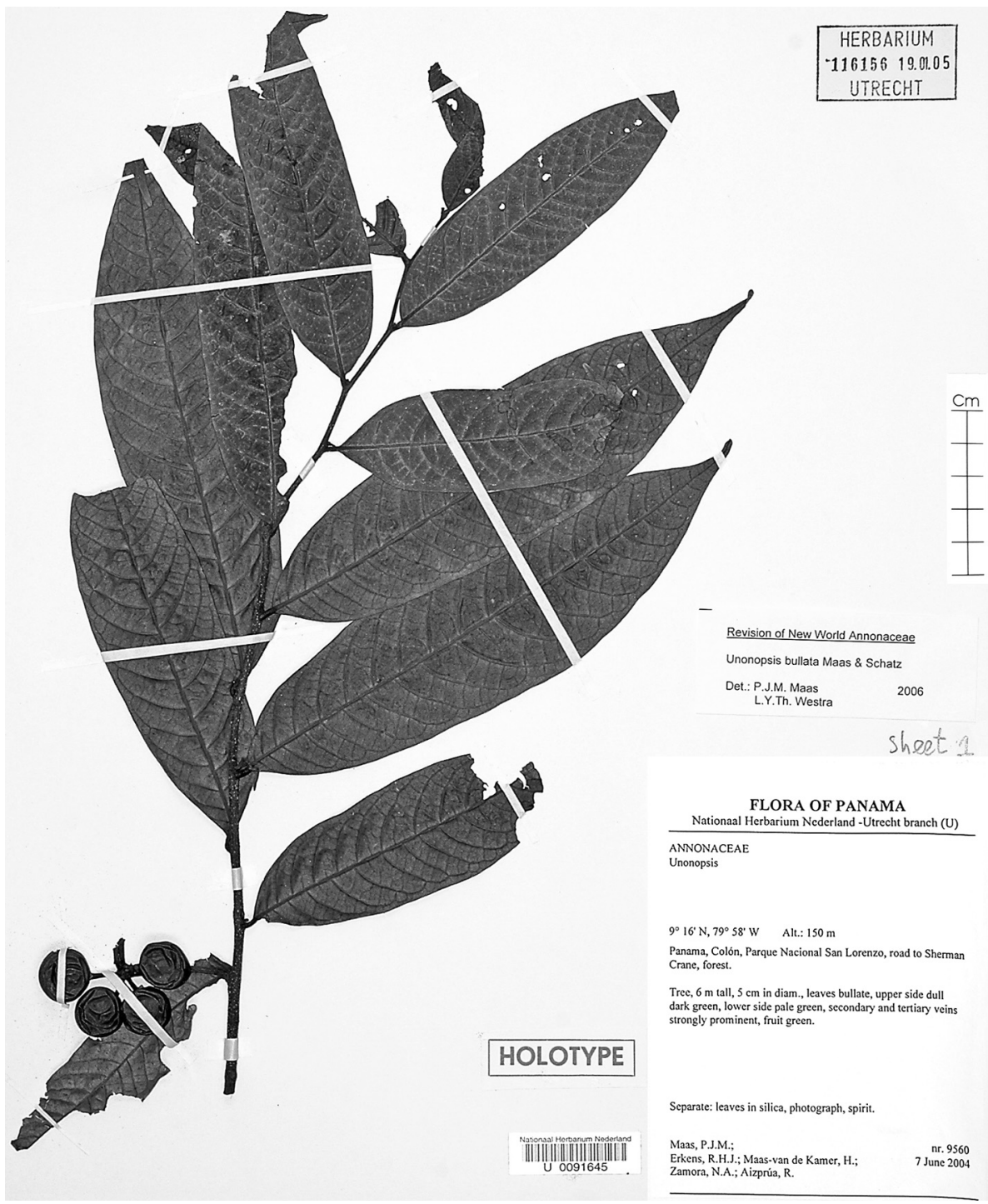

Fig. 14. Unonopsis bullata Maas \& G.E. Schatz. Fruiting twig (Maas et al. 9560, holo part 1, U).

Note - Unonopsis bullata stands out within the genus because of markedly bullate leaves. The only other species with a similar leaf feature is $U$. theobromifolia.

Selection of other specimens (20) examined:

Costa RicA. Limón: Cantón de Talamanca, Bratsi, Alto Lari, between Surayo and Dapari, 300 m, R. Aguilar \& Schmidt 995 (INB); Cantón de Talamanca, Fila de Matama, Pandora, Cerro Hule, 400 m, A. Rodríguez 636 (U).

Panama. Bocas del Toro: La Toyosa, near Chiriqui Grande, 125 m, Maas et al. 9532 (PMA, SCZ, U). Colón: road to Portobelo, 40 m, Lao \& Holdridge 161 (MO); Parque Nacional San Lorenzo, 


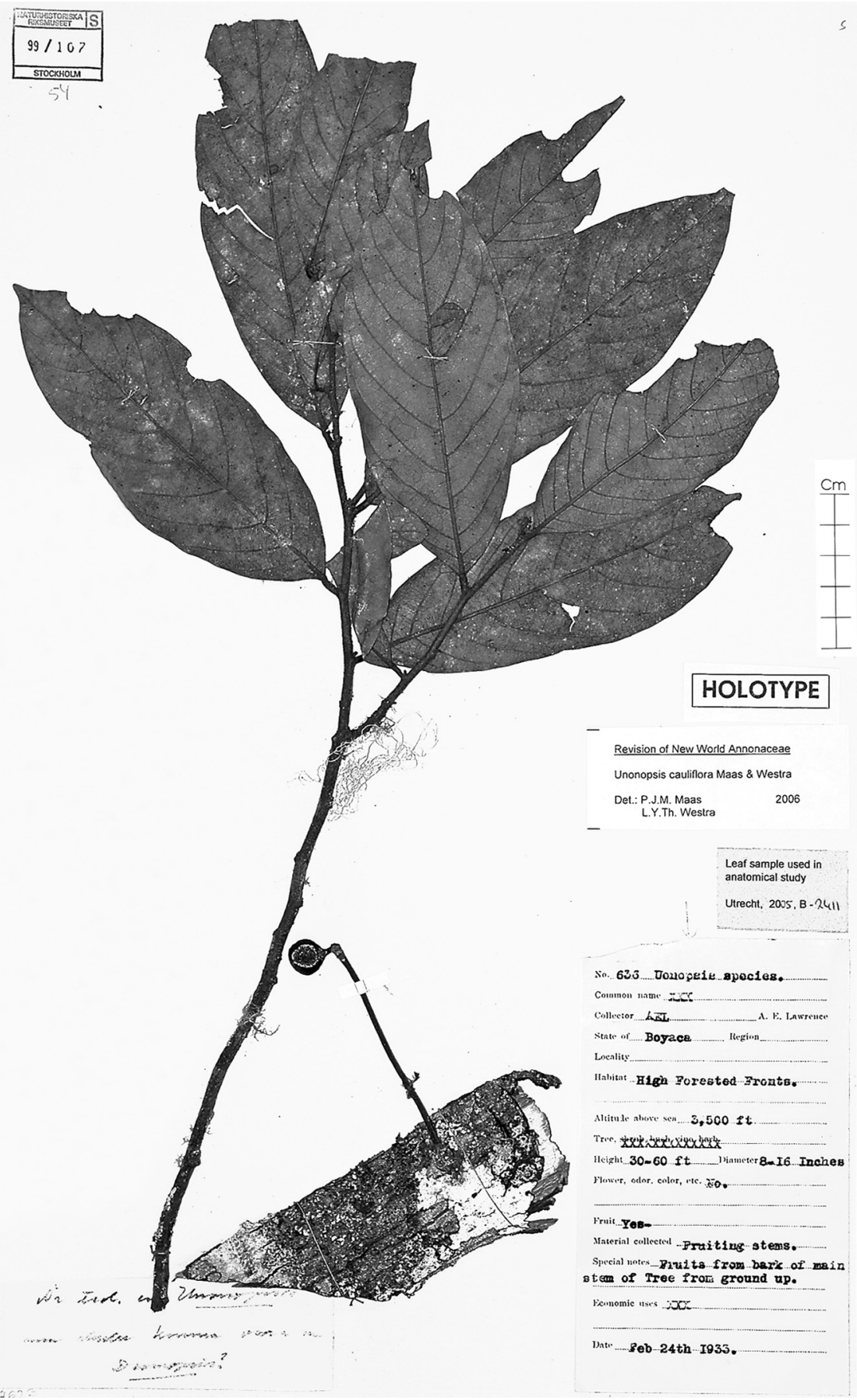

Fig. 15. Unonopsis cauliflora Maas \& Westra. Fruiting twig (Lawrance 636, isotype specimen, S - not the holotype!). 
near Fort Sherman, 30 m, Maas et al. 9576 (PMA, SCZ, U); Santa Rita Ridge, c. 12 miles E of Trans-isthmian road, $500 \mathrm{~m}$, McPherson 12463 (MO); along road to Piña, after turnoff from GatúnEscobal Road, $7.6 \mathrm{~km}$ N of turnoff towards Piña, Murray \& Johnson 1495 (MICH). Comarca de San Blas: trail to Cangandi, 3-30 m, De Nevers et al. 7413 (MO, U); near Nusigandi on El Llano-Carti Road, 300-350 m, McPherson 10748 (MO). Panamá: El Llano-Carti-Tupile road, 3 miles above Pan-American Hwy., 200-500 m, Croat et al. 22841 (F, MO, NA, NY); NW part of Canal Zone, Pavon road, Johnston 1545, 1629 (A, MO); NW part of Canal Zone, near Maru Towers, Johnston 1643 (MICH, MO).

\section{Unonopsis cauliflora Maas \& Westra, spec. nov. - Fig. 15; Map 8}

Species cauliflora, floribus pedicellis ad $80 \mathrm{~mm}$ longis suffultis, monocarpiis paucis 3-4seminalibus distincta. - Typus: Lawrance 636 (holo COL; iso A, F, G, K, P, S), Colombia, Boyacá, El Humbo, 130 miles N of Bogotá, 1000 m, 24 February 1933.

Cauliflorous tree 10-20 m tall, 20-40 cm diam.; young twigs densely covered with erect hairs, soon glabrous. Leaves: petiole 3-5 mm long, 2-3 mm diam.; lamina generally narrowly elliptic, symmetrical or slightly asymmetrical, $12-26$ by $4-8 \mathrm{~cm}$ (leaf index 2.3-3.3), chartaceous, rather densely to densely verruculose, dull and brown above, pale brownish green to pale greyish green below, sparsely covered with erect hairs, mainly along primary vein above, sparsely covered with appressed and erect hairs, mainly along primary and secondary veins below, base acute to obtuse, apex shortly acuminate (acumen $<5 \mathrm{~mm}$ long), secondary veins distinct, curved, $8-11$ on either side of primary vein, impressed above, angles with primary vein $45-50^{\circ}$, loopforming at right angles, smallest distance between loops and margin $2-3 \mathrm{~mm}$, tertiary veins distinct, percurrent. Inflorescences produced from the trunk, sometimes among leaves, compact or lax, composed of 1-several rhipidia; peduncle-like base absent; axial internodes $<1-10 \mathrm{~mm}$ long; rhipidia 1-3-flowered, to c. 6 flowers in succession,

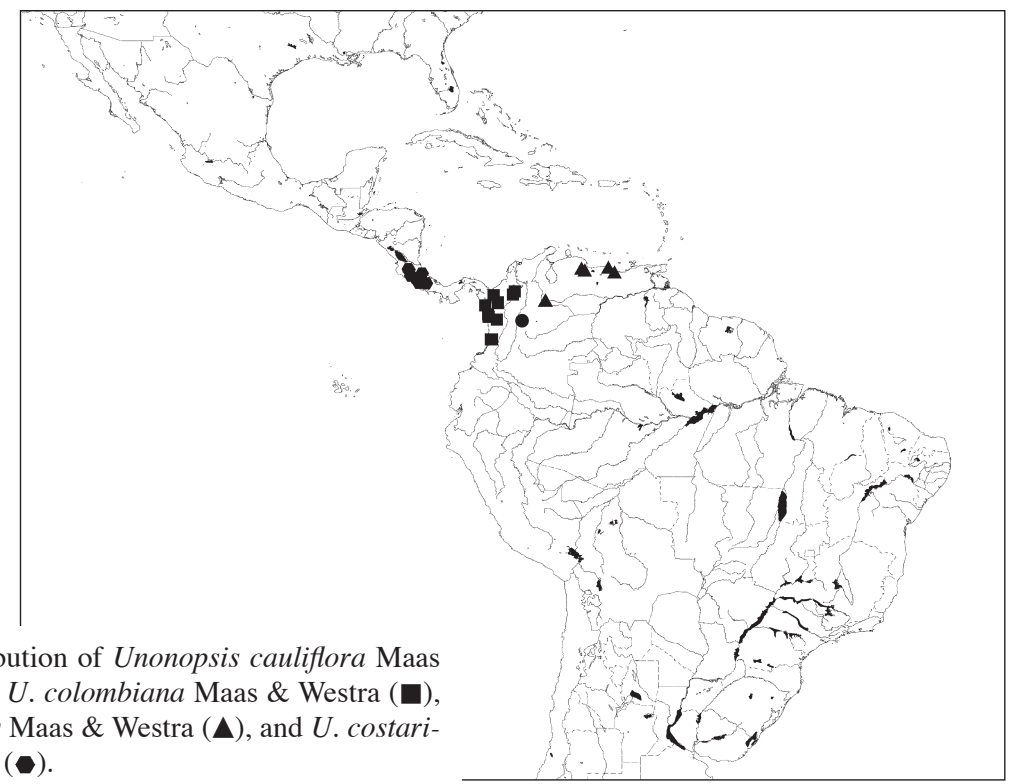

Map 8. Distribution of Unonopsis cauliflora Maas \& Westra (○), U. colombiana Maas \& Westra (ם), $U$. costanensis Maas \& Westra ( $\mathbf{\Delta})$, and $U$. costaricensis R.E. Fr (•). 
sympodial rachis to $10 \mathrm{~mm}$ long; upper bract at 1/4-1/2 from the base of the pedicel, ovate to depressed ovate, 1-2 mm long, outer side densely covered with appressed hairs; fruiting pedicels $70-80 \mathrm{~mm}$ long, 1-3 mm diam., rather densely to sparsely covered with appressed and erect hairs; flower buds, sepals, petals, stamens, and carpels not seen. Monocarps 5-15, black in sicco, globose to ellipsoid, c. 10 by 6-10 mm, sparsely covered with appressed hairs to finally glabrous, apex rounded to apiculate (apiculum $<0.1 \mathrm{~mm}$ long), wall $0.3-0.5 \mathrm{~mm}$ thick, stipes $2-5$ by $2 \mathrm{~mm}$; fruiting receptacle depressed ovoid, 3 by $4-5 \mathrm{~mm}$, densely covered with appressed and erect brown hairs. Seeds 3 or 4, lateral, $10-12$ by $10-12$ by $5-7 \mathrm{~mm}$, shiny brown.

Distribution - Colombia (Boyacá).

Habitat \& Ecology - In 'high forested fronts'. At an elevation of c. 1000 m. Flowering: unknown; fruiting: February. Only known from the type collection.

Note - Unonopsis cauliflora is recognized by its extremely long pedicels which are produced from the trunk.

\section{Unonopsis colombiana Maas \& Westra, spec. nov. - Fig. 16; Map 8}

Species foliis nervis secundariis supra distincte impressis, inflorescentiis paucifloris, monocarpiis paucis, 1-seminalibus distincta. - Typus: Monsalve B. 1989 (holo U; iso MO), Colombia, El Valle, Bajo Calima, c. 15 km N of Buenaventura, Cartón de Colombia concession, $100 \mathrm{~m}, 19$ October 1987.

Tree 3-15(-25) m tall; young twigs sparsely to rather densely covered with appressed and some erect small hairs, sometimes exclusively covered with erect small hairs, soon glabrous. Leaves: petiole 4-7 mm long, 1-2 mm diam.; lamina narrowly elliptic, sometimes narrowly obovate or elliptic, $9-24$ by $3-8 \mathrm{~cm}$ (leaf index $2.2-4.2$ ), chartaceous, rather densely or hardly verruculose, dull and brown, sometimes greyish brown above, brown below, glabrous or sparsely covered with appressed hairs, particularly along primary and secondary veins above, sparsely covered with appressed hairs to glabrous below, base acute, rarely obtuse, apex acuminate (acumen 5-10(-20) $\mathrm{mm}$ long), secondary veins distinct, curved, 10-14 on either side of primary vein, distinctly impressed above, angles with primary vein $50-60^{\circ}$, loop-forming at right to obtuse angles, smallest distance between loops and margin 1-4 mm, tertiary veins distinct, percurrent. Inflorescences among leaves or on older branchlets, composed of 1-3 rhipidia but often only a single rhipidium developing, compact to sublax, axial internodes $\leq 1-3$ $\mathrm{mm}$; rhipidia 1-3-flowered, usually a single fruit with pedicel on a basal part (of axial origin and/or partly sympodial rachis?) 5-15 mm long; upper bract at 1/3-1/2 from the base of the pedicel, shallowly ovate-triangular, c. $1 \mathrm{~mm}$ long, outer side rather densely covered with appressed hairs; pedicels $8-18 \mathrm{~mm}$ long, c. $1 \mathrm{~mm}$ diam., fruiting pedicels to $40 \mathrm{~mm}$ long, to $2(-3) \mathrm{mm}$ diam., densely covered with appressed and erect hairs, soon sparsely so to glabrous; flower buds depressed globose to globose; sepals initially largely connate, shallowly ovate-triangular, $1-1.5$ by $2-2.5 \mathrm{~mm}$, outer side sparsely to rather densely covered with appressed hairs; petals white to cream in vivo, outer ones broadly ovate, flat, $5-6$ by $5-6 \mathrm{~mm}$, outer side rather densely covered with appressed hairs, inner ones broadly ovate, concave, $3-5$ by $3 \mathrm{~mm}$, outer side glabrous except for hairy exposed part; stamens 1-1.5 mm long, connective shield glabrous; carpels c. 10, c. $2 \mathrm{~mm}$ long, densely covered with appressed hairs, ovule 1, basal. Monocarps 3-10, 


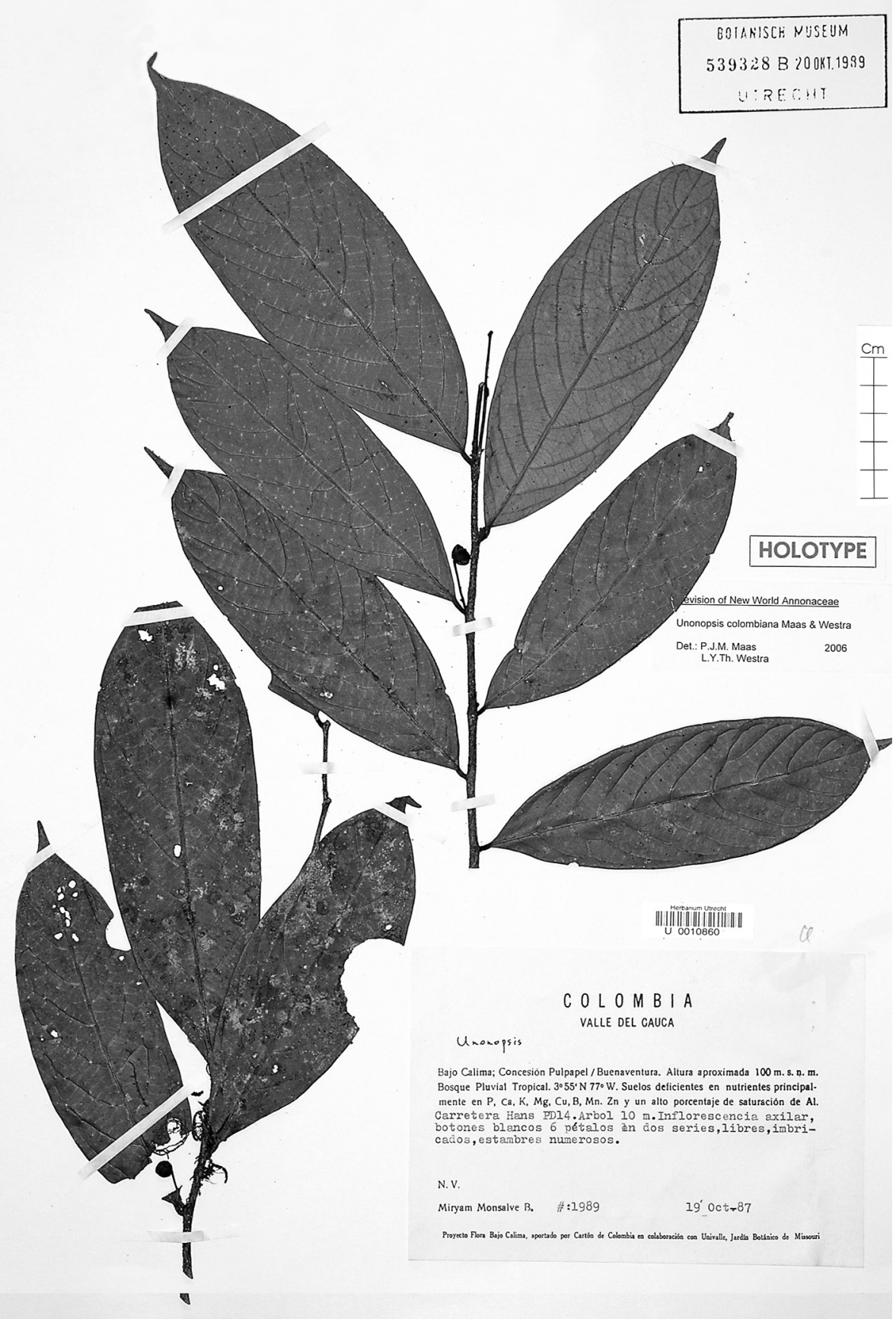

Fig. 16. Unonopsis colombiana Maas \& Westra. Flowering twig (Monsalve B. 1989, holo U). 
green, maturing purple-black in vivo, black to brown in sicco, globose to depressed globose, $10-15$ by $10-20 \mathrm{~mm}$, glabrous, except for some scattered appressed hairs, apex rounded, not apiculate, wall $0.2-0.4 \mathrm{~mm}$ thick, stipes $5-15$ by $1-2 \mathrm{~mm}$; fruiting receptacle subglobose, 2-7 mm diam., sparsely covered with appressed hairs. Seed 1 , lateral, $10-13$ by $10-11$ by $6-7 \mathrm{~mm}$, dark brown.

Distribution - Colombia (Antioquia, Bolívar, Chocó, Córdoba, El Valle).

Habitat \& Ecology - In non-inundated forest. At elevations of 0-520 m. Flowering: January, February, May, September to November; fruiting: February to April, August to December.

Vernacular names - Colombia: Cargadero, Koawi (Emberá).

Notes - Unonopsis colombiana is recognized by secondary veins which are strongly impressed on the upper side of the leaves, a few-flowered inflorescence, tiny flowers, and few, 1-seeded monocarps.

Some sterile collections (Gentry et al. 35555, 40297) have an obtuse instead of acute leaf base.

We have some doubts about the identity of Fonnegra G. et al. 1812 which is aberrant in having distinctly narrowly obovate leaves and 1- or 2-seeded monocarps.

Selection of other specimens (27) examined:

Colombia. Antioquia: Mun. Mutatá, Corregimiento Longani, 2 km N of Mutatá, 80-100 m, Callejas et al. 5685 (HUA, NY, U); Mun. Mutatá, Sitio Río Surumbay, 12 km N of Mutatá, 30-80 m, Callejas et al. 5785 (HUA); Mun. Mutatá, 8-20 km S of Mutatá, road to Dabeiba, Alto de Echeverri, 210-230 m, Callejas et al. 5809 (HUA, MO, NY, U); road from Mutatá to Pavarandó, between Haciendas La Esperanza and Mocarí, 150 m, Fonnegra G. et al. 1812 (HUA, MO, U); Mun. Caucasia, along road to Nechí, $24 \mathrm{~km}$ from Caucasia-Planeta road, Hacienda Costarica, $60 \mathrm{~m}$, Zarruchi et al. 4901 (HUA). Bolívar: La Raya, Quebrada La Culebra, Caño Caribon, between junction of Río Canca and Río Magadalena, 50-80 m, Gentry \& Cuadros 57272 (MO). Chocó: Mun. Riosucio, region of Urabá, Cerro del Cuchillo, road from Cuchillo Negro to Cumbre norte, 10-520 m, Cárdenas L. et al. 440 (MO); Mun. Riosucio, Corregimiento Macondo, region of Urabá, Cerros del Cuchillo, road from Cuchillo Negro to La Cumbre Sur, 30-100 m, Cárdenas L. et al. 931 (MO); trail between Río Curiche and camp Curiche, 5-60 m, Duke 11603 (MO, NY); Mun. Bahia Solano, Punta Huina, Espina et al. 3134 (HUA); mouth of Río Atrato, near Beté, 50-60 m, Forero et al. 8859 (COL, U); Ensenada de Utría, Río Bodobodo, 0-280 m, García-Barriga 15425 (COL); Quibdó-Tutunendo road, c. 3 km W of Tutunendo, 80 m, Gentry et al. 30145 (MO); Upper Río Baudó, Emberá, Quebrada de Condoto, 280 m, La Rotta \& Martínez 667 (COL). Córdoba: Montelíbano, $5 \mathrm{~km}$ before Uré, Leguízamo et al. 1073 (COL); Mun. Ayapel, Finca Canime, Marulanda 2065 (HUA). El Valle: Bajo Calima, c. 15 km N of Buenaventura, Cartón de Colombia concession, 50 m, Gentry 35555 (COL, MO); idem, $100 \mathrm{~m}$, Monsalve B. 652 (MO, U).

\section{Unonopsis costanensis Maas \& Westra, nom. \& stat. nov. - Map 8}

Unonopsis umbilicata (Dunal) R.E. Fr. subsp. macrocarpa R.E. Fr. (1941) 105. - Type: Ll. Williams 10315 (holo VEN; iso F, S, US, VEN), Venezuela, Aragua, Parque Nacional Henri Pittier, El Portachuelo, 1200-1300 m, 27 August 1938. Not Unonopsis macrocarpa Maas \& Setten in Maas et al. (1988).

Tree 4-18 m tall, up to $30 \mathrm{~cm}$ diam.; young twigs sparsely covered with appressed hairs, soon glabrous. Leaves: petiole 5-7 mm long, 2-3 mm diam.; lamina narrowly elliptic, sometimes narrowly obovate, $11-28$ by $3.5-9 \mathrm{~cm}$ (leaf index $2.8-4$ ), chartaceous, often verruculose along primary and secondary veins, shiny above, grey to greyish brown above, brown to grey below, glabrous above, except for some appressed hairs along 
primary vein, sparsely covered with appressed hairs along primary vein or rarely all over below, base acute to obtuse, apex acuminate (acumen 5-15 $\mathrm{mm}$ long), secondary veins distinct, curved, 10-15 on either side of primary vein, raised above, angles with primary vein $45-55^{\circ}$, loop-forming at right angles or hardly loop-forming, smallest distance between loops and margin 1-3 mm, tertiary veins distinct, percurrent. Inflorescence among leaves, terminal (or perhaps seemingly so by abortion of vegetative shoot apex), or on older branches, mostly a single rhipidium on a short axis, or compact and composed of 2 or 3 rhipidia; rhipidia 1-3-flowered, to 5 flowers in succession, sympodial rachis of variable length, up to $15 \mathrm{~mm}$ long and with internodes to $5 \mathrm{~mm}$ long; upper bract at 1/8-1/3 from the base of the pedicel, broadly ovate-triangular, $1-1.5$ $\mathrm{mm}$ long, outer side rather densely to densely covered with appressed hairs; pedicels 7-20 $\mathrm{mm}$ long, $1 \mathrm{~mm}$ diam., fruiting pedicels $15-35 \mathrm{~mm}$ long, to $2 \mathrm{~mm}$ diam., rather densely to sparsely covered with appressed hairs; flower buds ovoid; sepals basally connate, shallowly ovate-triangular, $1-2$ by $1.5-2 \mathrm{~mm}$, outer side densely covered with appressed hairs; petals white to yellow in vivo, outer ones ovate, flat, $6-8$ by $4-5 \mathrm{~mm}$, outer side densely covered with appressed hairs, inner ones broadly ovate, concave, 3-6 by 3-4 mm, outer side glabrous except for hairy exposed part; stamens c. $1.5 \mathrm{~mm}$ long, connective shield glabrous; carpels c. 10, 1.5-2 mm long, densely covered with appressed hairs, ovule 1, lateral. Monocarps (1-)4-10(-20), green in vivo, brown, rarely black in sicco, transversely ellipsoid to globose, $15-25$ by $12-25 \mathrm{~mm}$, rather densely covered with appressed hairs, soon glabrous, apex rounded, not apiculate, wall $0.3-0.5 \mathrm{~mm}$ thick, stipes $5-20$ by $1-2 \mathrm{~mm}$; fruiting receptacle globose to depressed globose, $3-7$ by $3-9 \mathrm{~mm}$, rather densely to sparsely covered with appressed hairs. Seed 1, lateral to apical, $13-16$ by $11-14$ by $9-11 \mathrm{~mm}$, dark shiny brown.

Distribution - Northern Venezuela, in the Cordillera de la Costa (Aragua, Carabobo, Miranda, Sucre, Tachira, Yaracuy).

Habitat \& Ecology - In cloud forest. At elevations of 400-1300 m. Flowering: October to January, June; fruiting: August to April.

Vernacular names - Venezuela: Guanabita, Macagua.

Notes - Unonopsis costanensis looks superficially like U. guatterioides, but it is immediately distinct by its 1 -seeded, rather than several-seeded, monocarps.

Unonopsis costanensis was originally described as U. umbilicata Dunal subsp. macrocarpa R.E. Fr. We could barely find any resemblance with $U$. umbilicata Dunal subsp. umbilicata. The latter is only known from the type collection which lacks precise data on the origin ('Granada') and the collector ('Forsyth'). Further details about $U$. umbilicata are given under the Insufficiently known species.

As the name $U$. macrocarpa Maas \& Setten (Maas et al., 1988) already existed, a new name had to be substituted. The epithet 'costanensis' refers to the Cordillera de la Costa in northern Venezuela.

Other specimens examined:

Venezuela. Aragua: Parque Nacional 'Henri Pittier', Rancho Grande, near Pico Periquito, Agostini \& Fariñas 96 (F, K, MY, NY, U, US, VEN). Carabobo: above Río San Gián, S of Borburata, between La Toma and 'Capuchinos', 750-1000 m, J.A. \& C. Steyermark 95229 (NY, S, U). Miranda: Guatopo, 400-600 m, Bernardi s.n. (NY); Dto. Paéz, Fila la Tigra, Quebrada San Juan, 18 km SW of Cúpira, 750 m, González \& Ortega 1213 (F, MO, NY, PORT, U, WIS); Cordillera de la Costa, NE of Guatire, between Fila Las Perdices and Río Guayabal, 800-900 m, Meier 3391 (U). Sucre: vicinity of Manacal, Carreño s.n. (MO, VEN). Táchira: La Buenana, 6-12 km W of 

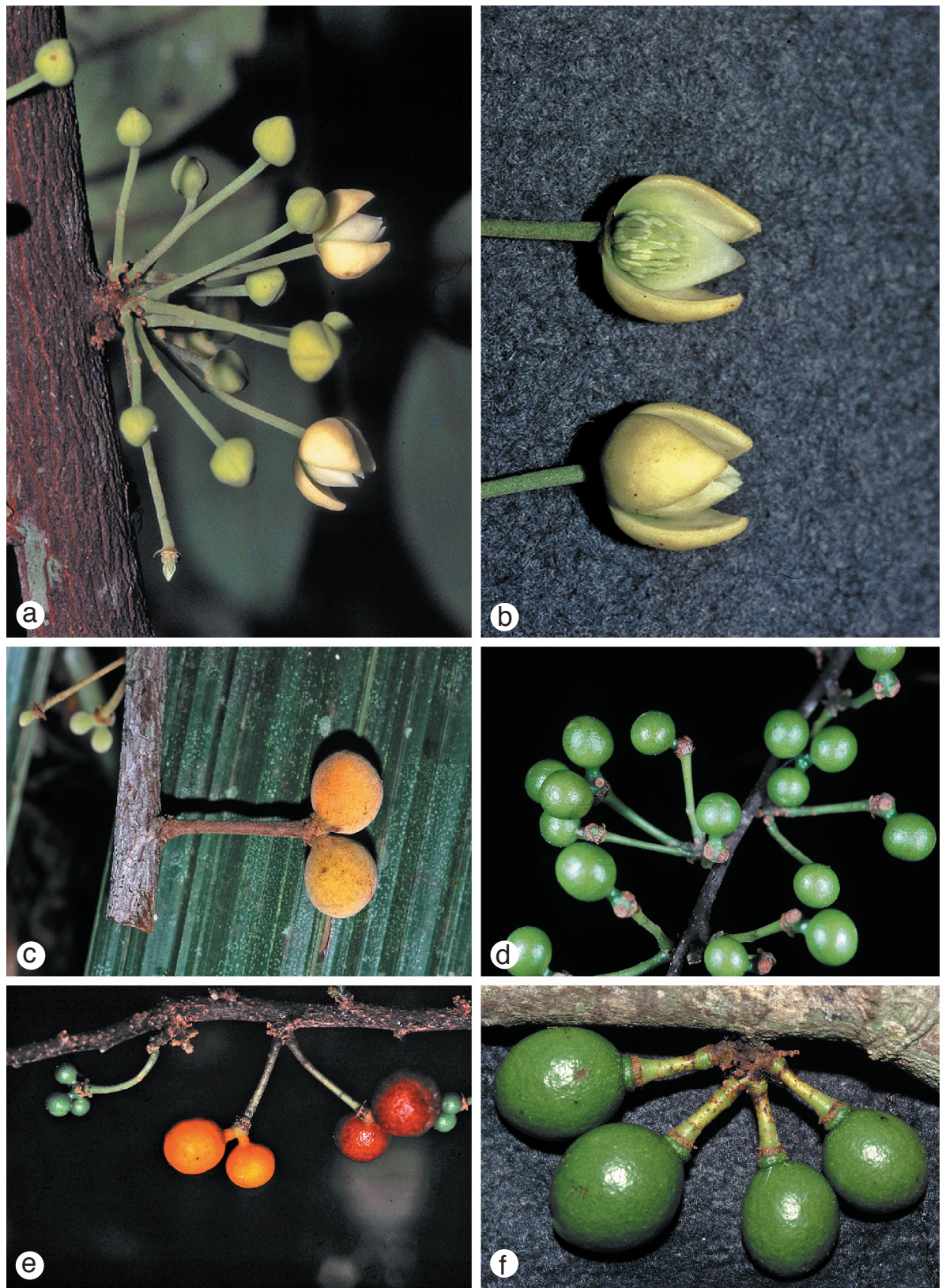

Plate 1. a-c. Bocageopsis canescens (Benth.) R.E. Fr.; d, e. B. multiflora (Mart.) R.E. Fr.; f. Onychopetalum periquino (Rusby) D. M. Johnson \& N.A. Murray. - a. Inflorescence; b. flower entire and with part of petals removed; c-f: various infructescences (a, b: Maas et al. 6242; c: Maas et al.9243; d: Hopkins \& Nascimento 1507; e: Maas et al. 6953; f: Maas et al. 9255). — Photos by P. Maas. 

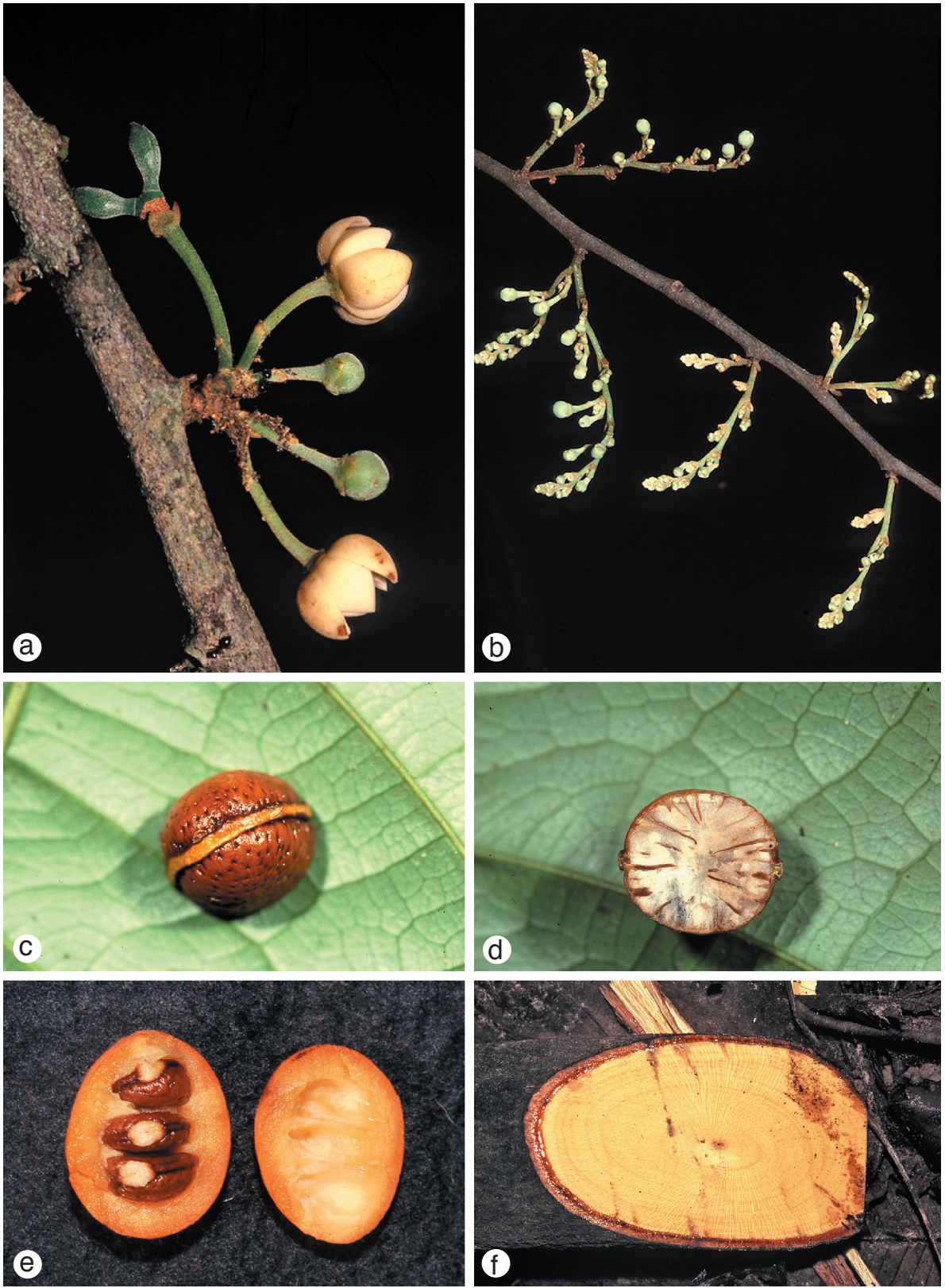

Plate 2. a. Unonopsis guatterioides (A.DC.) R.E. Fr.; b. U. rufescens (Baill.) R.E. Fr.; c, d. U. stipitata Diels; e. U. storkii Standl. \& L.O. Williams; f. U. spectabilis Diels. - a, b. Inflorescences; c. seed; d. transverse section of seed; e. longitudinal section of monocarp, seeds with conspicuous hilum; f. bark with red exudate (a: Maas et al. 6837; b: Maas et al. 7136; c, d: Chatrou et al. 160; e: Maas et al. 9530; f: Maas et al. 6229). - Photos: a, e, f by P. Maas; b by L. Westra; c, d by L. Chatrou. 
Quebrada Colorada, c. 35 km SSE of San Cristóbal, 600-1000 m, Liesner \& González 10781 (MO, NY, U); Cerro de Cuite, along Quebrada La Colorada, 4-6 km S of Campamento Colorada, 450-630 m, Steyermark et al. 119759 (MO, U). Yaracuy: Sierra de Aroa, Cerro Tigre, W of Río Carabobo, 10 km E of Aroa air distance, 1000 m, Liesner \& González 9981 (MO, U); Cumbre Gamelatal, 4.3-11 $\mathrm{km} \mathrm{N}$ of Salom, on road from Salom to Candelaria, 1000-1200 m, Mori et al. 14672 (F, U, VEN); El Amparo, near Candelaria, 7-10 km N of Salom, 1200-1300 m, Steyermark et al. 106731 (NY, U, US); San Felipe, $3.3 \mathrm{~km} \mathrm{~S}$ of Candelaria, $12 \mathrm{~km} \mathrm{~N}$ of Salom, $1040 \mathrm{~m}$, Steyermark et al. 123769 (U); Distr. San Felipe, Río Taria, $10 \mathrm{~km}$ N of Salom, El Amparo, Vuelta de Pavo, $5 \mathrm{~km} \mathrm{~S}$ of Candelaria, 1200 m, Steyermark \& Carreño E. 123801 (U, VEN).

\section{Unonopsis costaricensis R.E. Fr - Map 8}

Unonopsis costaricensis R.E. Fr. (1941) 105. - Type: Standley 33897 (holo US; fragment S), Costa Rica, Cartago, El Muñeco, S of Navarro, 1400 m, 8-9 February 1924.

Tree 5-16 m tall, 20-25 cm diam.; young twigs rather densely covered with erect white hairs, soon glabrous. Leaves: petiole 5-7 mm long, 1-2 mm diam.; lamina narrowly elliptic, symmetrical to slightly asymmetrical, $13-16$ by $3.5-5 \mathrm{~cm}$ (leaf index $3.2-3.7$ ), chartaceous, rather densely verruculose, dull above, brown to greenish brown above, brown below, sparsely covered with erect hairs along primary vein to glabrous above, sparsely covered with appressed, long hairs, particularly along primary vein, to glabrous below, base acute, apex acuminate (acumen 5-10 $\mathrm{mm}$ long), secondary veins distinct, curved, 10-14 on either side of primary vein, raised above, angles with primary vein $50-60^{\circ}$, loop-forming at right angles, smallest distance between loops and margin 2-3 mm, tertiary veins distinct, percurrent. Inflorescences among leaves or on older branches, (as far as seen:) a single flower or mostly fruit, or sometimes 2 fruits, axis 3-20 mm long, with internodes $1-5 \mathrm{~mm}$ long; upper bract at $1 / 5-2 / 3$ from the base of the pedicel, broadly ovate to broadly triangular, 1-2 $\mathrm{mm}$ long, outer side sparsely to densely covered with appressed hairs; pedicels c. $15 \mathrm{~mm}$ long, c. $1 \mathrm{~mm}$ diam., fruiting pedicels $25-50 \mathrm{~mm}$ long, 2-4 mm diam., densely to finally sparsely covered with appressed hairs; flower buds very broadly ovoid; sepals basally connate, shallowly ovate-triangular, c. 2 by $2.5-3 \mathrm{~mm}$, outer side densely to sparsely covered with appressed and erect hairs; petals cream in vivo, outer ones broadly ovate, slightly concave, c. 8 by $9 \mathrm{~mm}$, outer side sparsely covered with appressed hairs, inner ones not seen; stamens c. $1 \mathrm{~mm}$ long, connective shield glabrous; carpels $>50$, c. $1 \mathrm{~mm}$ long, densely covered with appressed hairs, ovules not yet studied. Monocarps 5-50, green, maturing red in vivo, dark brown in sicco, globose to ellipsoid, 14-20 by 13-16 mm, sparsely covered with appressed hairs to finally glabrous, apex apiculate (apiculum $<0.5$ $\mathrm{mm}$ long), wall c. $1 \mathrm{~mm}$ thick, stipes $5-10$ by $1-2 \mathrm{~mm}$; fruiting receptacle depressed ovoid, 5-7 by 7-10 mm, rather densely covered with appressed and erect hairs. Seeds $1-3$, lateral, $12-15$ by $10-12$ by $9-10 \mathrm{~mm}$, dark to pale brown.

Distribution - Costa Rica (Alajuela, Cartago, Guanacaste, San José).

Habitat \& Ecology - In forest. At elevations of 800-1400 m. Flowering: March; fruiting: April, September to January.

Vernacular names - Costa Rica: Anonillo.

Notes - Unonopsis costaricensis is endemic to Costa Rica where it occurs at rather high elevations. It is recognized by small, brown drying, verruculose leaves, relatively long pedicels up to 50 by $4 \mathrm{~mm}$, and thick-walled, 1-3-seeded monocarps. 
Floral measurements are quite unsatisfactory as only one incomplete and dried flower was available for study.

All specimens but one showed old inflorescences in fruiting stage, therefore the precise structure of the axis at the base (i.e., sympodial rachis in part?) could not be determined. Unfortunately, in the one specimen available with an old flower (Davidse \& Herrera 26282, MO) the inflorescence base is obscured by mounting.

Mora Castro 369 (U), collected in the costarican province of Limón between 400-500 m elevation, shows some similarity with $U$. costaricensis particularly by the long-stalked fruit and the colour of the dried leaves. The leaves, however, are broader than in U. costaricensis, with a leaf index of 2-2.8. This specimen has inflorescences in various stages, from juvenile through flowering to fruiting. The structure can be described as lax, the axis with internodes to $5 \mathrm{~mm}$. There is one rhipidium, 2-flowered.

The two following fruiting specimens, also from the costarican province of Limón, possibly belong here, but do not match satisfactorily in all respects: G. Herrera \& A. Chacón 2691 (INB, U) from El Progreso, Fila Matama, Valle de la Estrella, $1150 \mathrm{~m}$ and A. Chacón 741 (U) from Cantón Guápiles, Los Angeles, San Miguel, following the trail to Volcán Irazú, headwaters of Río Blanco and Río Blanquito, 1300 m. They differ from other material of $C$. costaricensis in being cauliflorous, by longer fruiting pedicels (50-80 $\mathrm{mm}$ long) with clear traces of a compact thyrsoid at their base, one pedicel showing a basal bract quite close to the articulation (c. 1/20 from base), and non-verruculose leaves. They may represent an undescribed species, but as flowers are lacking we have refrained from formal publication. In the general key to the species of Unonopsis these specimens key out as 'U. costaricensis p.p.'.

\section{Unonopsis darienensis Maas \& Westra, spec. nov. - Fig. 17; Map 9}

Species foliis anguste obovatis, ramulis novellis pilis erectis sat dense obtectis, monocarpiis 1-3-seminalibus distincta. - Typus: McPherson 15398 (holo F; iso U), Panama, Darién, $\mathrm{S}$ of Garachiné on W slope of Serranía Sapo, above Casa Vieja, along boundary trail of Parque Nacional Darién, 150 m, 26 May 1991.

Tree or shrub 3-15 m tall; young twigs rather densely to densely covered with erect, brownish, short hairs, soon glabrous. Leaves: petiole 4-15 mm long, 2-5(-8) mm diam.; lamina narrowly obovate, $15-45$ by $4-16(-22) \mathrm{cm}$ (leaf index $2.5-4.2$ ), chartaceous, densely verruculose, dull above, greyish green to greyish brown above, pale brown to greenish below, primary vein densely covered with erect hairs above, otherwise glabrous, rather densely to soon sparsely covered with erect hairs below, mainly along primary and secondary veins, base acute to obtuse, apex acuminate (acumen 5-15 $\mathrm{mm}$ long), secondary veins distinct, curved, 13-16 on either side of primary vein, impressed above, angles with primary vein $45-50^{\circ}$, loop-forming at right to obtuse angles, smallest distance between loops and margin 1-2 mm, tertiary veins distinct, percurrent. Inflorescences on older branches, compact, composed of (1-)2-5 rhipidia; peduncle-like base absent; rhipidia 2- or 3-flowered, up to 15 flowers in succession; sympodial rachis to $15 \mathrm{~mm}$ long; upper bract at c. $1 / 3$ from the base of the pedicel, broadly ovate, c. $1 \mathrm{~mm}$ long, outer side densely covered with appressed brown hairs; pedicels 8-15 mm long, c. $1 \mathrm{~mm}$ diam., fruiting pedicels $15-35 \mathrm{~mm}$ long, 2-5 $\mathrm{mm}$ diam., densely covered with appressed and erect brown hairs; flower buds subglobose; sepals basally connate, shallowly triangular, $1.5-2.5$ by $1.5-3 \mathrm{~mm}$, outer side densely 


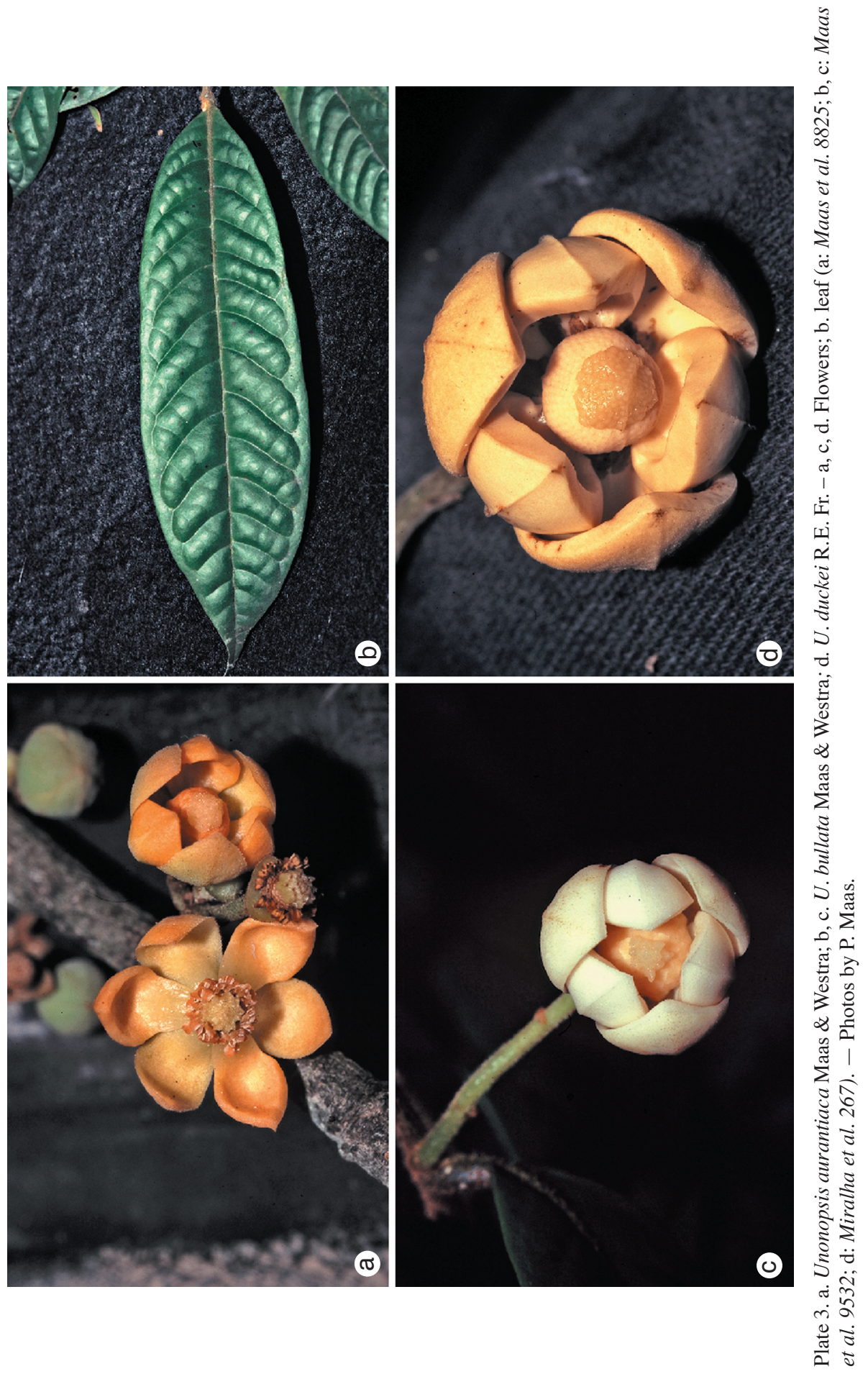



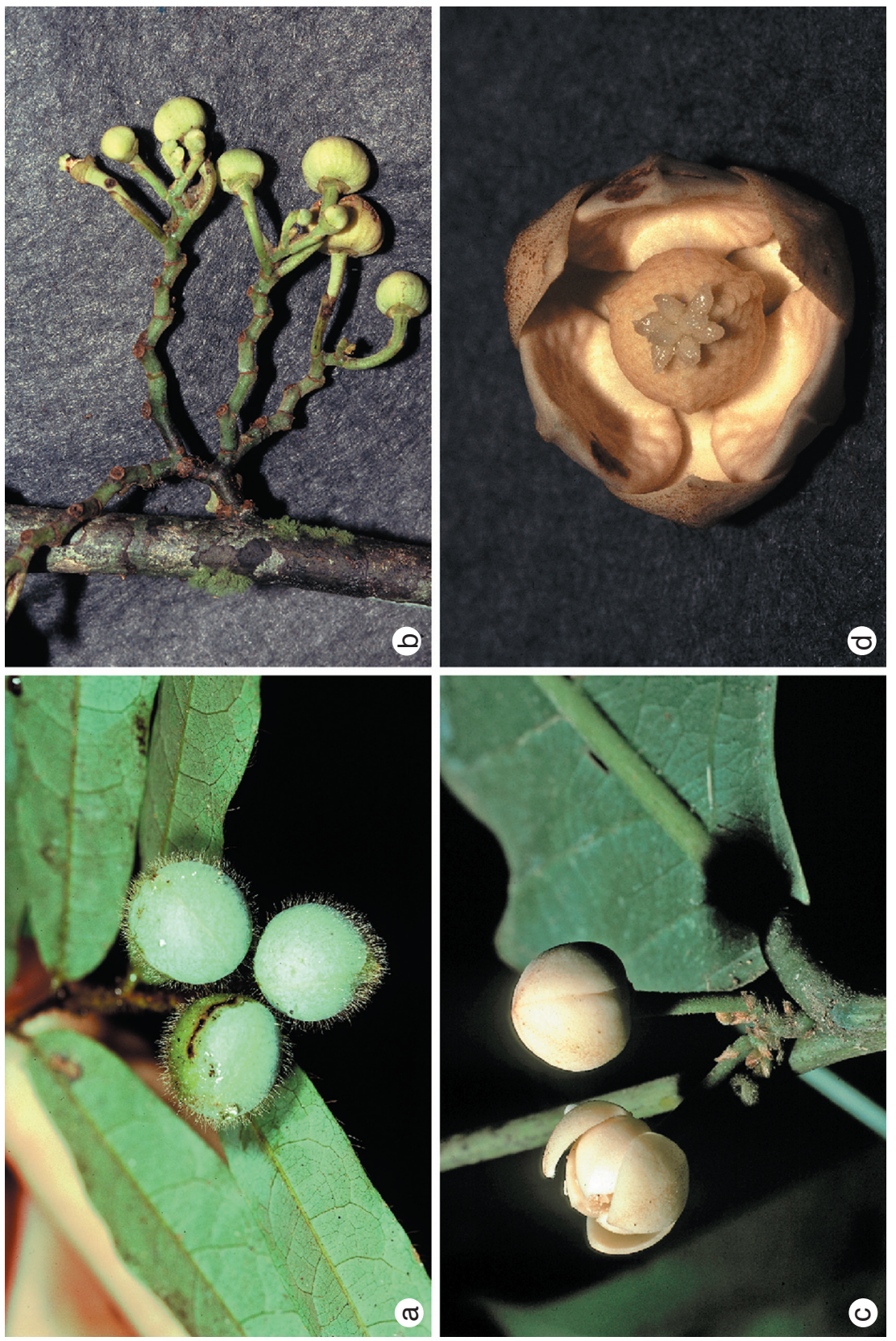

$\frac{0}{3}$

0
$\vdots$
0
0
0
0
0
0
0
0
0
0
0
0

范

ن ล

0 .

竞

ชं

है

荘 ठ

บ

苨

ชิ่

近

ปิ

ส

¿े

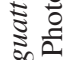

$\triangleright$ ।

نं

is 6

बे

군

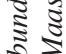

ปั

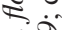

ว่ จิ

in

$\because \bar{\sigma}$

म

피

ป

¿

.

$\lesssim \infty$

$\stackrel{\pi}{\pi}$

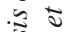

的

월

(4)

ه

ष๐

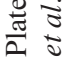




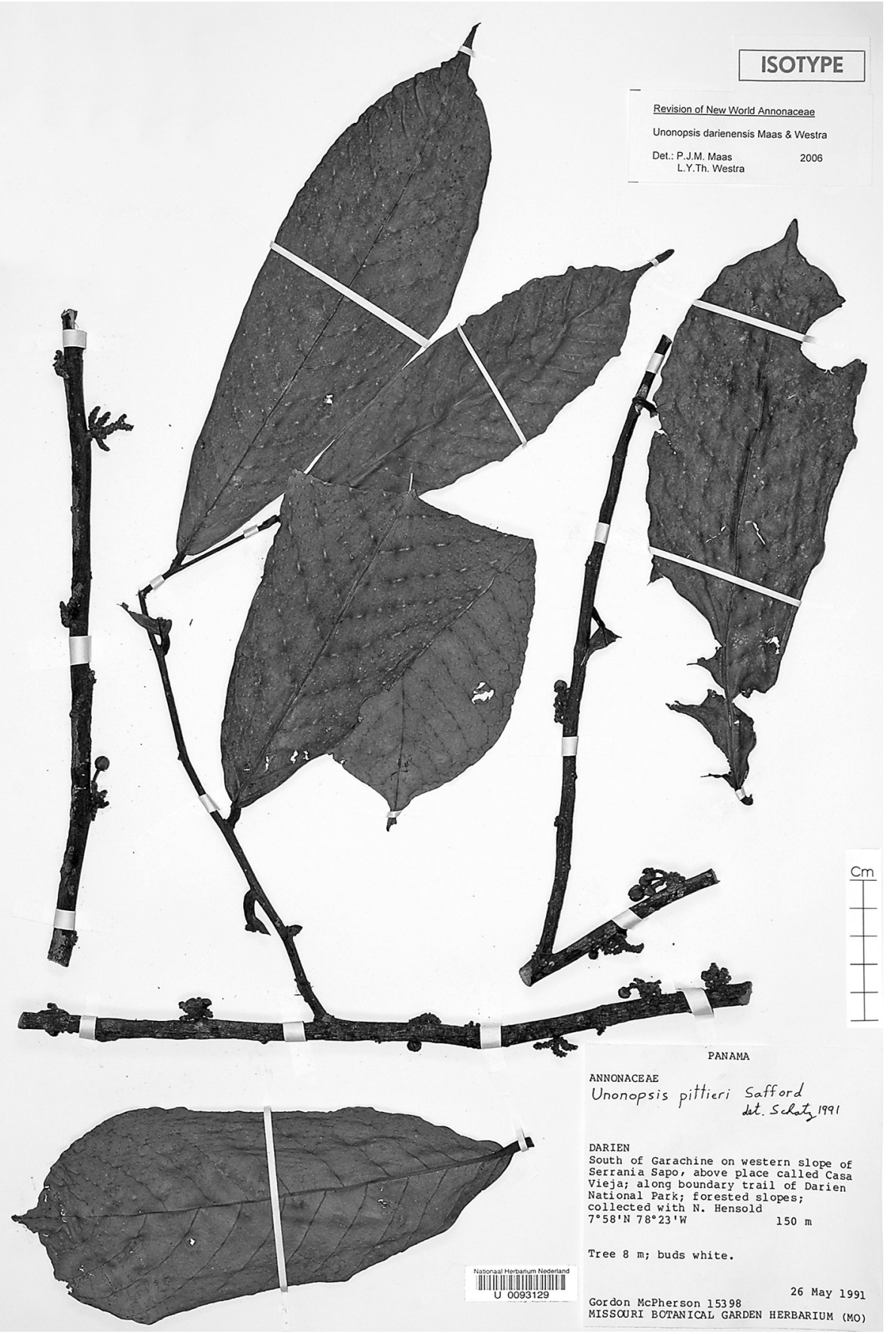

Fig. 17. Unonopsis darienensis Maas \& Westra. Flowering twig (McPherson 15398, iso U). 
covered with appressed brown hairs; petals greenish, white, or cream in vivo, outer ones broadly ovate, slightly concave, $6-8$ by $5-6 \mathrm{~mm}$, outer side densely covered with appressed brown hairs, inner ones broadly ovate, strongly concave, $4-5$ by 3-4 $\mathrm{mm}$, outer side glabrous, but keel densely hairy; stamens 1-1.5 mm long, connective shield glabrous; carpels c. 10,2-2.5 mm long, densely covered with appressed whitish hairs, ovules not yet studied. Monocarps 2-30, green to dark red, with 'bluish bloom' in vivo, black in sicco, ellipsoid to subglobose, $10-18$ by $10-13 \mathrm{~mm}$, rather densely covered with appressed hairs, soon glabrous, apex rounded, not apiculate, wall c. 0.5 $\mathrm{mm}$ thick, stipes $5-20$ by $1-2 \mathrm{~mm}$; fruiting receptacle subglobose, 5-6 mm diam., densely covered with appressed hairs, soon becoming sparsely so. Seeds 1-3, lateral, $8-10$ by $7-8$ by $5-6 \mathrm{~mm}$, pale brown.

Distribution - Panama (Comarca de San Blas, Darién) and Colombia (Antioquia, Chocó).

Habitat \& Ecology - In forest ('headwaters of river, rocky banks of stream'). At elevations of $0-400 \mathrm{~m}$. Flowering: May to July, October; fruiting: throughout the year.

Notes - Unonopsis darienensis (mostly incorrectly identified as $U$. pittieri before) is recognized by a combination of narrowly obovate leaves, an indument of erect hairs on the young twigs, and 1-3-seeded monocarps. Its exact affinities are still unknown.

Kirkbride \& Duke 1237 (MO, NY) from Panama, Darién, Coasi-Cana trail on Cerro Campamiento, E of Tres Bocas, cloud forest, no elevation indicated, may belong to $U$. darienensis, but the material is too incomplete to be completely sure.

Monocarps of one sheet of Galdames et al. $1317(\mathrm{U})$ are probably aborted and have a pointed instead of a rounded apex. One leaf of that collection is extremely large, namely 43 by $22 \mathrm{~cm}$, and its petiole c. $8 \mathrm{~mm}$ diameter!

Selection of other specimens (20) examined:

PANAma. Comarca de San Blas: PEMASKY, Sendero Nusagandi, km 18 of El Llano-Cartí Rd., 350 m, Galdames et al. 1317 (PMA, SCZ, U). Darién: W side of SW ridge leading to Alturas

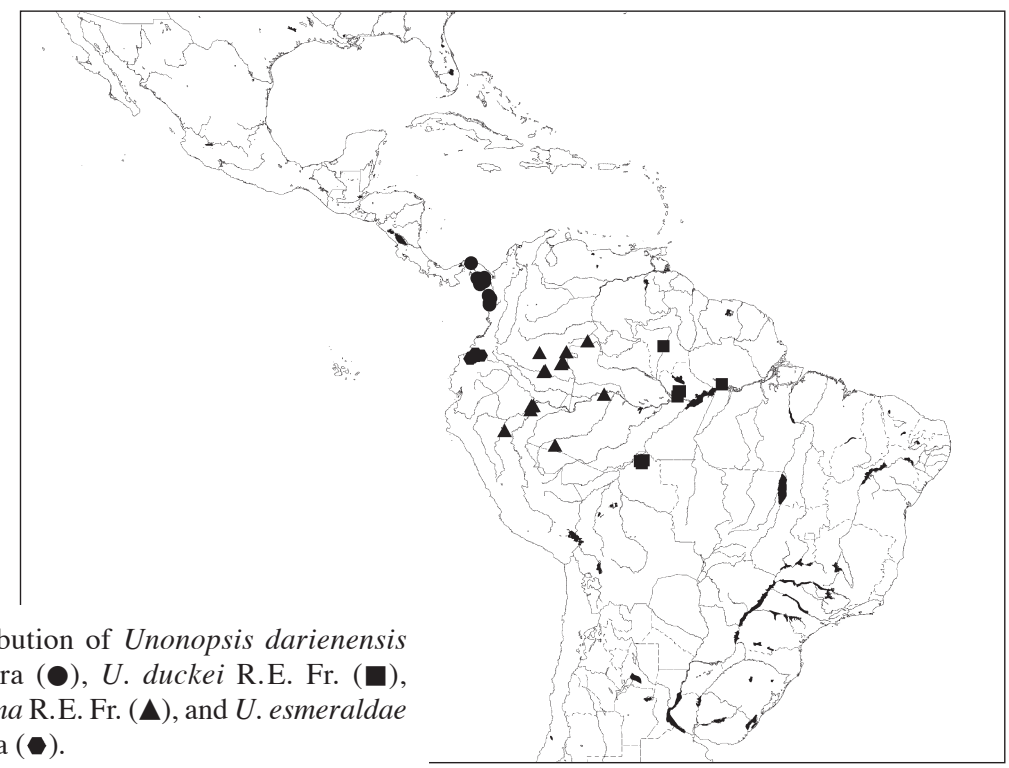

Map 9. Distribution of Unonopsis darienensis Maas \& Westra (๑), U. duckei R.E. Fr. (ם), U. elegantissima R.E. Fr. ( $\mathbf{\Delta})$, and $U$. esmeraldae Maas \& Westra (-). 


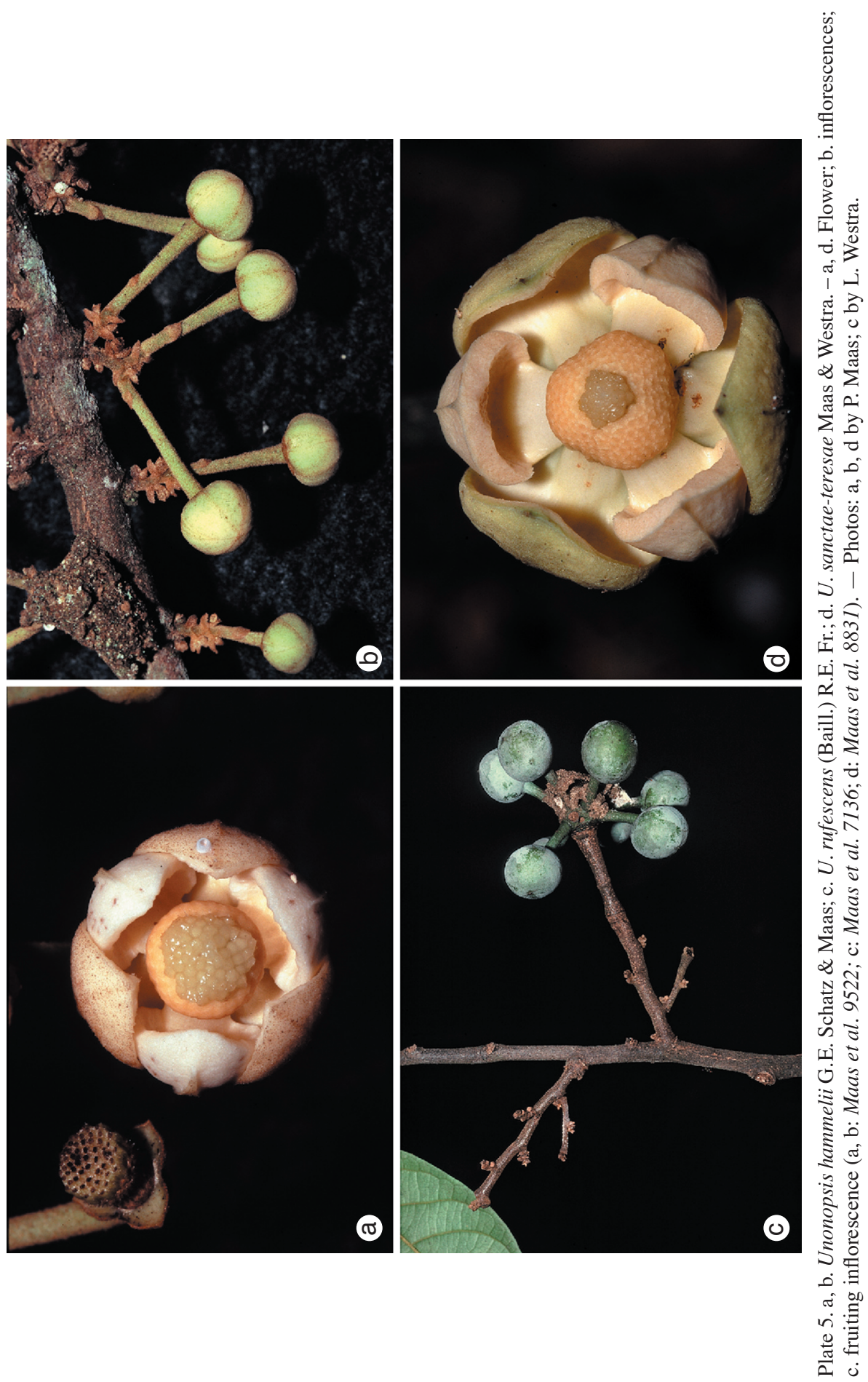



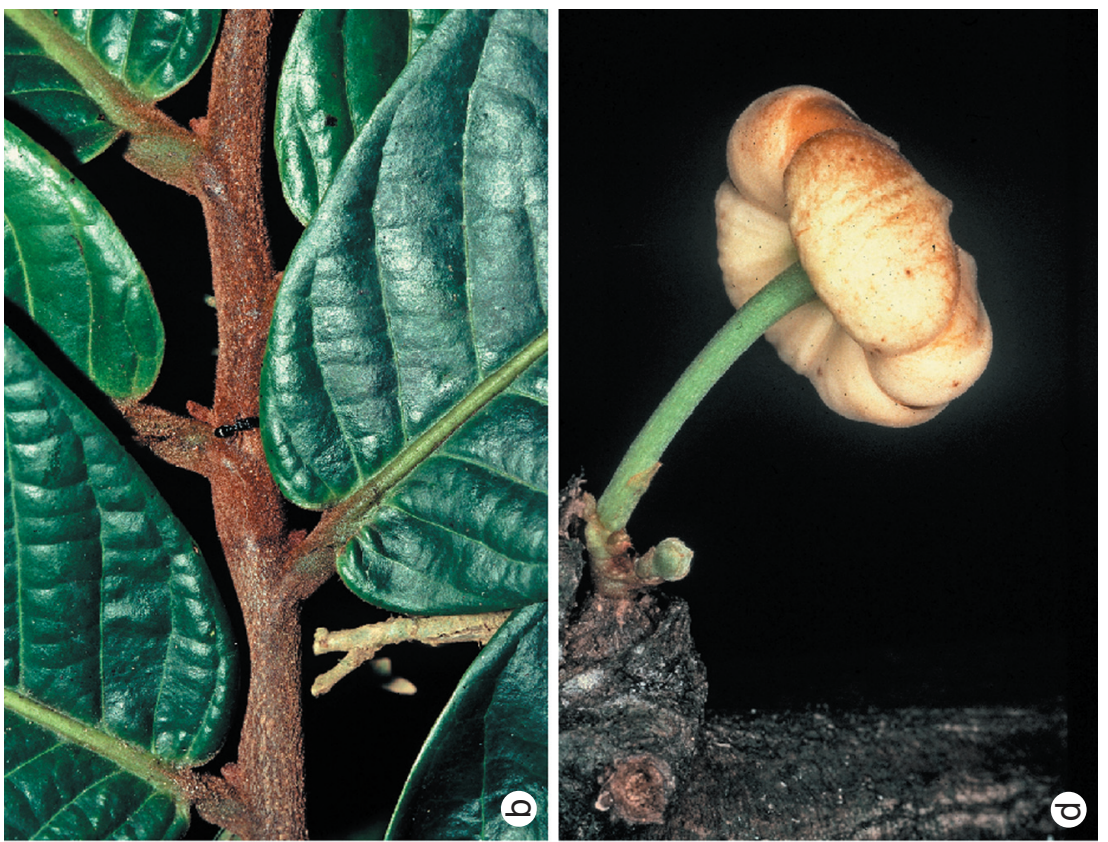

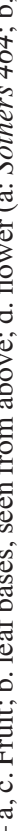
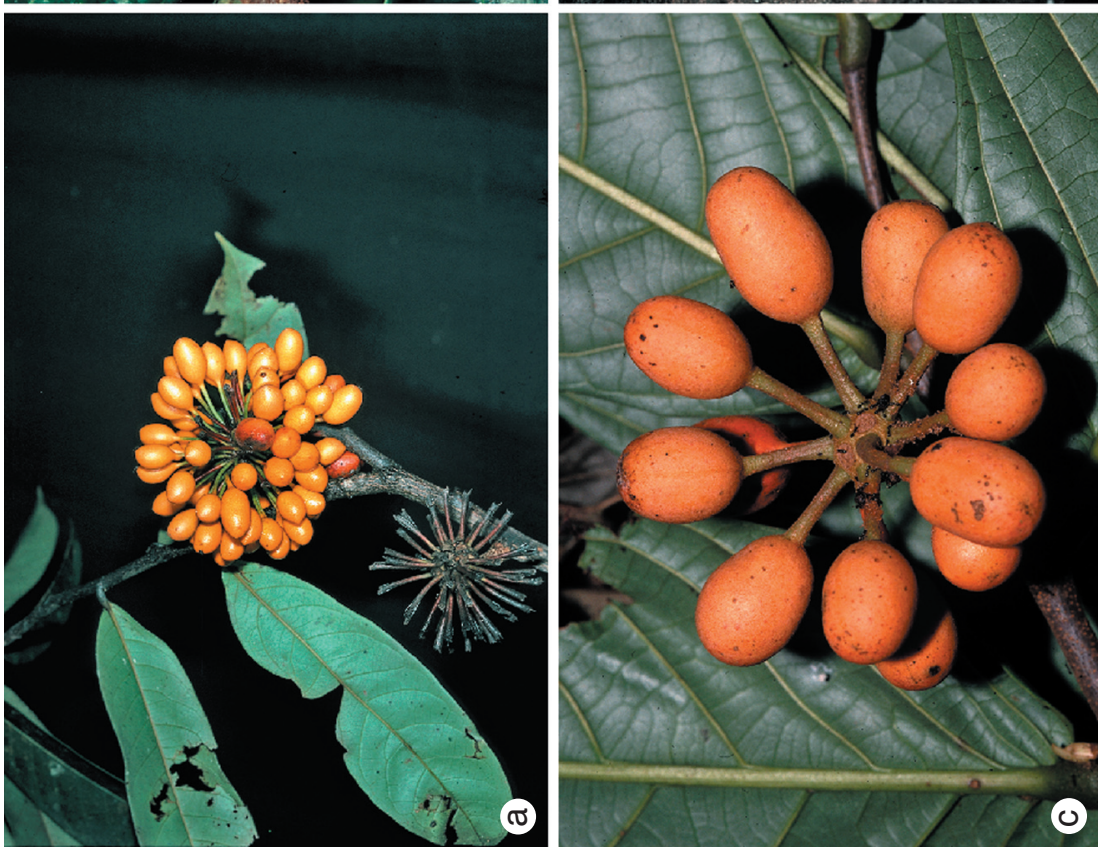

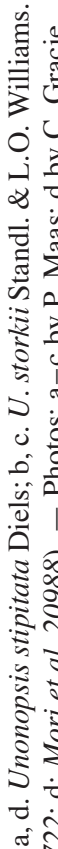

ชั

$\frac{\mathbb{E}}{\tilde{n}} \tilde{\Xi}$ 
de Nique, headwaters of Río Coasi, 400 m, Hartman 12294 (MEXU, MO, U); S of Garachiné near Pacific coast above Casa Vieja, along boundary trail of Parque Nacional Darién, W flank Serranía Sapo, 140 m, Hensold 1134 (U); Parque Nacional Darién, Estación Pirre, 150 m, H. Herrera 696 (U); N of Punta Guayabo Grande, NW of Ensenada El Guayabo ridges, 0-200 m, Knapp \& Mallet 3170 (MO, U, WIS); $10 \mathrm{~km}$ NE of Jaqué, slopes of Río Tabuelitas abover Birogueirá, Indian village on Río Jaqué, below mouth of Río Pavarandó, c. 150 m, Sytsma \& D’Arcy 3326 (MO, U).

Colombia. Antioquia: Mun. Mutatá, $3 \mathrm{~km}$ WSW of Mutatá, along road to Pavarandogrande, 170 m, Zarucchi et al. 5054 (HUA, MO, U). Chocó: Mun. Nuquí, Corregimiento Termales, between Quebrada Piedra Piedra and Río Terco, 5-10 m, Acevedo R. et al. 6949 (HUA, U, US); Quebrada Sansoré, road from Boroboro to hidroelectric station of Mutatá, 0-100 m, Barbosa 6519(U); Parque Nacional de Utría, NE of Ensenada de Utría, 0-100 m, García C. \& Agualimpia 501 (M).

Three sterile collections from the Pacific coast of Colombia, with gigantic leaves up to 65 by $20 \mathrm{~cm}$ (!) and an obtuse to cordate base, may belong here: ColOMBIA. Chocó: trail from Quibdó-Tutunendo Road to Tubadó, 14 km NE of Quibdó, 90 m, Gentry et al. 24487 (COL, HUA, U); Quibdó-Tutunendo Road, 3 km W of Tutunendo, 80 m, Gentry et al. 30131 (U). El Valle: Bajo Calima Concession, 17 km NW of Buenaventura, 4 km N of km 22.5, Faber-Langendoen \& Hurtado 1870 (U).

\section{Unonopsis duckei R.E. Fr. - Plate 3d; Map 9}

Unonopsis duckei R.E. Fr. (1939) 561. - Type: Ducke RB 29010 (holo S; iso RB, U), Brazil, Amazonas, Manaus ('ultra coloniam João Alfredo'), 6 December 1935.

Tree (7-)10-30 m tall, 15-25 cm diam.; young twigs rather densely covered with appressed hairs, soon glabrous. Leaves: petiole 3-10 mm long, 1-2 mm diam.; lamina generally narrowly elliptic to narrowly obovate, symmetrical to slightly asymmetrical, 9-26 by $4-8 \mathrm{~cm}$ (leaf index $2.3-4.2$ ), chartaceous, densely verruculose, smooth, dull on both sides, or somewhat shiny above, greyish green to brownish above, often brownish below, glabrous above, primary vein and secondary veins sparsely covered with appressed hairs to glabrous below, base acute to somewhat attenuate, apex acuminate (acumen 5-20 mm long), secondary veins distinct, curved, 8-13 on either side of primary vein, slightly raised to impressed above, angles with primary vein $40-60^{\circ}$, loop-forming at obtuse to right angles, smallest distance between loops and margin $2-5 \mathrm{~mm}$, tertiary veins indistinct, percurrent. Inflorescences on older branches, rarely among leaves, compact, composed of $1-4$ rhipidia; peduncle-like base $0-2 \mathrm{~mm}$ long; rhipidia 1-3-flowered, to 7 flowers in succession; sympodial rachis to $10 \mathrm{~mm}$ long; upper bract at 1/5-1/2 from the base of the pedicel, very broadly ovate, $1-2.5 \mathrm{~mm}$ long, outer side rather densely to densely covered with appressed silvery brown hairs; pedicels (5-)10-35 $\mathrm{mm}$ long, 1-2 $\mathrm{mm}$ diam., fruiting pedicels to $50 \mathrm{~mm}$ long, to $4 \mathrm{~mm}$ diam., rather densely to densely covered with appressed silvery brown hairs; flower buds very broadly ovoid; sepals basally connate, very broadly to shallowly ovatetriangular, $1.5-4$ by $1.5-5 \mathrm{~mm}$, outer side densely covered with appressed silvery brown hairs; petals cream to yellow in vivo, outer ones longitudinally striped at the outer side, broadly to depressed ovate, concave, $10-16$ by $8-15 \mathrm{~mm}$, outer side densely covered with appressed silvery brown hairs, inner ones depressed ovate, concave, 7-10\{-13) by 7-12 mm, outer side subglabrous except for hairy exposed part; stamens $1-1.5 \mathrm{~mm}$ long, connective shield glabrous; carpels > 100, 0.5-1 mm long, densely covered with appressed yellowish white hairs, ovule 1, basal. Monocarps 30-70, green when young, maturing yellow to orange in vivo, reddish brown in sicco, ellipsoid to broadly ellipsoid, 
13-18 by $10-11 \mathrm{~mm}$, sparsely covered with appressed hairs to finally glabrous, apex rounded and sometimes asymmetrically apiculate (apiculum $0.1-0.2 \mathrm{~mm}$ long), wall $0.2-0.3\{-1.5\} \mathrm{mm}$ thick, stipes $20-30$ by $1-1.5 \mathrm{~mm}$; fruiting receptacle often depressed ovoid, $6-15$ by $10-15 \mathrm{~mm}$, densely covered with erect and appressed, brown hairs. Seed 1 , basal, $9-11$ by $6-9$ by $5-7 \mathrm{~mm}$, brown to dark brown.

Distribution - Amazonian Brazil (Amazonas, Pará, Rondônia).

Habitat \& Ecology - In non-inundated forest, on clayey or sandy soils. At elevations up to $125 \mathrm{~m}$. Flowering: June to December; fruiting: May to December.

Vernacular names - Brazil: Envira, Envira cascuda, Envira preta, Envira surucucu, Envireira.

Notes - Unonopsis duckei is characterized by comparatively large flowers, the outer petals of which are covered by appressed silvery brown hairs. They share the ellipsoid monocarps with $U$. stipitata and consequently many collections of $U$. duckei had been misidentified. However, apart from the much larger flowers, U. duckei generally has smaller leaves than $U$. stipitata.

Boom 8720 is somewhat deviating by more or less globose monocarps.

\section{Unonopsis elegantissima R.E. Fr. - Plate 4a; Map 9}

Unonopsis elegantissima R.E. Fr. (1939) 561; Murillo-A. \& Restrepo (2000) 155, f. 51. - Type: Klug 2524 (holo S; iso A, F, NY, U, US), Peru, Loreto, Mishuyacu, near Iquitos, February 1932.

Tree or shrub 2.5-5 m tall, to $12 \mathrm{~cm}$ diam.; young twigs hirsute: sparsely to rather densely covered with erect, rough, pale yellow hairs $0.5-3 \mathrm{~mm}$ long. Leaves: petiole 1-7 $\mathrm{mm}$ long, 1-2 mm diam.; lamina narrowly elliptic to narrowly obovate, often slightly asymmetrical, $8-25$ by $1.5-6 \mathrm{~cm}$ (leaf index $3-6$ ), chartaceous, slightly verruculose or not, dull and greyish brown to greyish green on both sides, sparsely covered with appressed hairs to glabrous above, sparsely covered with appressed hairs below, base rounded to cordate, often slightly asymmetrical, apex acuminate (acumen 5-25 mm long), secondary veins indistinct, curved, 6-15 on either side of primary vein, impressed above, angles with primary vein $50-70^{\circ}$, loop-forming at right to obtuse angles, smallest distance between loops and margin 1-4 mm, tertiary veins indistinct, not percurrent. Inflorescences among leaves, often near ends of twigs and seemingly terminal due to abortion of vegetative growth tip, rarely on older branches, a single rhipidium with 1 flower, rarely to 3 flowers in succession; upper bract at 1/3-1/2 from the base of the pedicel, very broadly ovate-triangular, $0.5-1 \mathrm{~mm}$ long, outer side rather densely to densely covered with appressed hairs; pedicels $2.5-10 \mathrm{~mm}$ long, $0.5-1.5 \mathrm{~mm}$ diam., fruiting pedicels to $20(-45) \mathrm{mm}$ long, to $2.5 \mathrm{~mm}$ diam., sparsely to densely covered with erect hairs; flower buds ovoid, slightly pointed; sepals free to basally connate, very broadly to shallowly triangular, $0.5-2$ by $1-2(-3) \mathrm{mm}$, outer side rather densely to densely covered with appressed hairs; petals cream in vivo, outer ones ovate-triangular to broadly so, slightly concave, $4-7\{-9\}$ by $3-6\{-7\} \mathrm{mm}$, outer side densely to rather densely covered with appressed hairs, inner ones ovate-triangular, strongly concave, $4-7\{-8\}$ by $3-6\{-7\} \mathrm{mm}$, outer side glabrous except for hairy exposed part; stamens 1-1.5 mm long, connective shield glabrous; carpels 3-5, 2-3 mm long, densely covered with appressed to semierect hairs, ovules 2, lateral. Monocarps 1-6, green, maturing orange to red in vivo, brown in sicco, globose to ellipsoid 7-20 by 
7-20 mm, sparsely covered with erect, long hairs to finally glabrous, apex rounded, often somewhat pointed or apiculate (apiculum $0.2-0.3 \mathrm{~mm}$ long), wall $0.2-0.3\{-4\}$ $\mathrm{mm}$ thick, stipes $2-8$ by $1-2 \mathrm{~mm}$; fruiting receptacle ellipsoid to globose, $2-5$ by $2-5$ $\mathrm{mm}$, densely covered with appressed and erect hairs. Seeds 1 or 2, lateral, 8-12 by 7-9 by $5-6 \mathrm{~mm}$, reddish brown to brown.

Distribution - Amazonian Colombia and Peru and the Upper Amazon Region of Brazil.

Habitat \& Ecology - In non-inundated forest, on clayey soil or on white sands. Mostly at elevations up to $650 \mathrm{~m}$. Flowering: August, from October to March; fruiting: August to April.

Vernacular names - Peru: Carahuasca, Espintana.

Notes - Unonopsis elegantissima is unique because of its rough hairs (up to $3 \mathrm{~mm}$ long) on vegetative parts.

The leaf size in this species is quite variable, the material from Peru (mainly from white sands) has narrow leaves $(8-14$ by $1.5-3 \mathrm{~cm}$ ), whereas most material from Colombia and Brazil has longer and wider leaves, namely $8-25$ by $2-6 \mathrm{~cm}$.

Pennington \& Daza 17236(U) from Yurimaguas, Loreto, Peru is somewhat aberrant in having the inflorescences produced from leafless branches instead of near the end of leafy twigs.

\section{Unonopsis esmeraldae Maas \& Westra, spec. nov. - Fig. 18; Map 9}

Species monocarpiis transverse ellipsoideis vel globosis bene distincta. - Typus: Daly \& Acevedo R. 5163 (holo U; iso AAU, K, MO, NY), Ecuador, Esmeraldas, Mun. Lita, Río Lita and tributaries, affluent of Río Mira, $117 \mathrm{~km} \mathrm{NW}$ of Ibarra, $12 \mathrm{~km} \mathrm{~N}$ of Lita, 600 m, 10 May 1987.

Tree 6-25 m tall, 3.5-12 cm diam.; young twigs rather densely to sparsely covered with appressed hairs, soon glabrous. Leaves: petiole 5-12 mm long, 1.5-3 mm diam.; lamina narrowly obovate to narrowly elliptic, $13-29$ by $5-12 \mathrm{~cm}$ (leaf index $2.2-2.7$ ), chartaceous, sparsely to rather densely verruculose or not verruculose, greyish brown above, pale brown below, primary and secondary veins rather densely to sparsely covered with erect hairs above, otherwise glabrous, sparsely covered with appressed hairs below, base acute, sometimes obtuse, apex acuminate (acumen 5-15 mm long), secondary veins distinct, curved, 10-13 on either side of primary vein, impressed or slightly raised above, angles with primary vein $45-55^{\circ}$, loop-forming at right angles, smallest distance between loops and margin 2-4 mm, tertiary veins distinct, percurrent. Inflorescences among leaves or on older branches, a single rhipidium on a short axis, or sublax and composed of 2 (or 3) rhipidia; peduncle-like base 2-5 mm long; axial internodes 1-3 mm long, or whole axis (in fruiting stage) 8-10 mm long; rhipidia 2- or 3 -flowered; upper bract at c. $1 / 4$ from the base of the pedicel, shallowly ovate-triangular, 0.5-1 mm long, outer side densely covered with appressed hairs; pedicels 5-30 mm long, $1 \mathrm{~mm}$ diam., fruiting pedicels to $35 \mathrm{~mm}$ long, 1.5-2 mm diam., rather densely covered with appressed, brown hairs; flower buds depressed globose; sepals almost completely connate, shallowly ovate-triangular, $0.5-1.5$ by $1-3 \mathrm{~mm}$, outer side rather densely covered with appressed brown hairs; petals green to cream or white in vivo, outer ones broadly ovate, flat, $4-6$ by $5-6 \mathrm{~mm}$, outer side rather densely covered with 


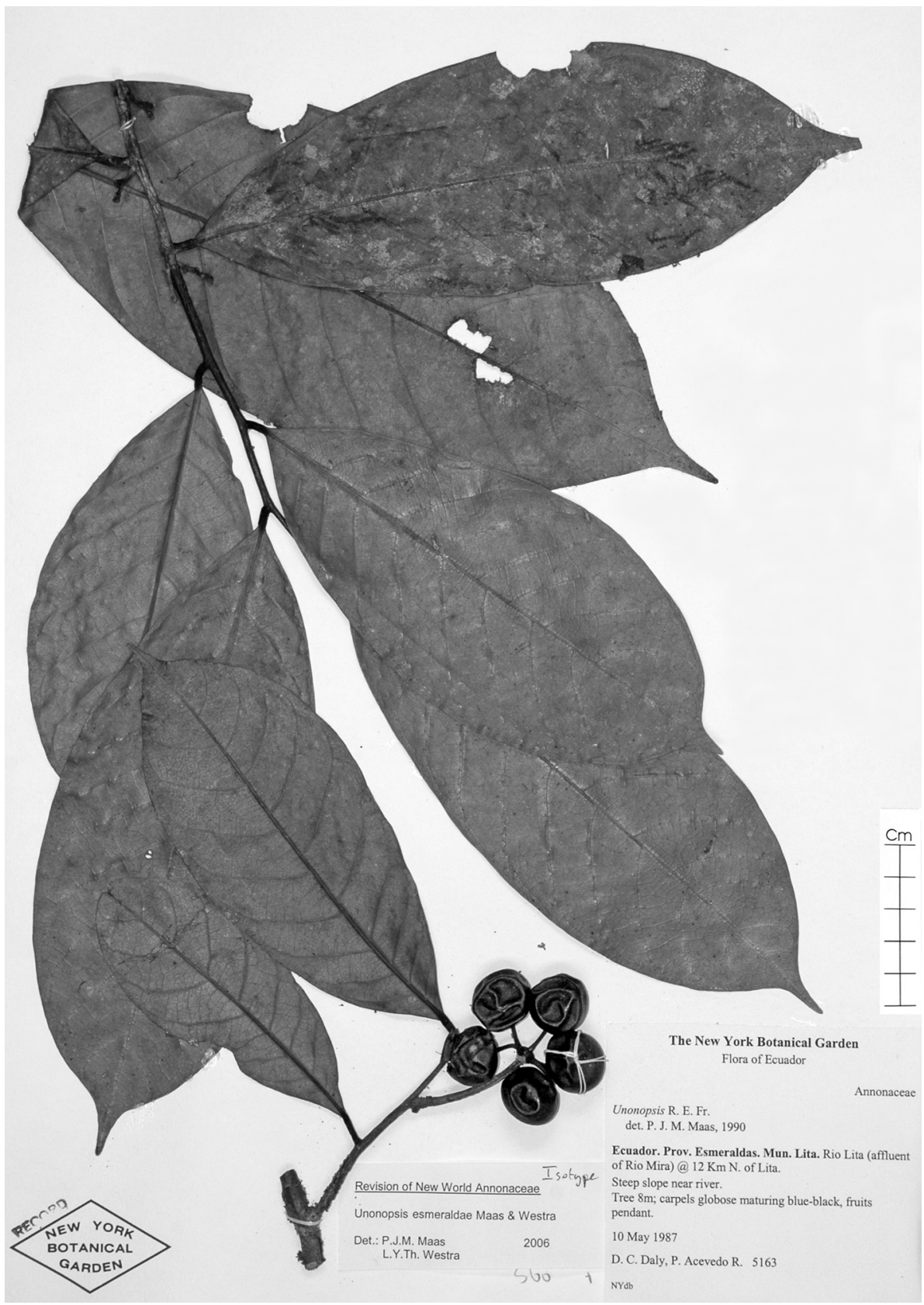

Fig. 18. Unonopsis esmeraldae Maas \& Westra. Fruiting twig (Daly \& Acevedo R. 5163, iso NY). 
appressed brown hairs, inner ones broadly ovate, concave, $3-5$ by $3-5 \mathrm{~mm}$, outer side glabrous except for hairy exposed part; stamens c. $1 \mathrm{~mm}$ long, connective shield glabrous; carpels c. 12, c. $1.5 \mathrm{~mm}$ long, densely covered with appressed white hairs, ovule 1, suprabasal. Monocarps 1-10, green, maturing purple-black in vivo, black in sicco, transversely ellipsoid to globose, $12-15$ by $15-20 \mathrm{~mm}$, sparsely covered with appressed hairs, soon glabrous, apex rounded, not apiculate, wall $0.2-0.3 \mathrm{~mm}$ thick, stipes $10-15$ by $1 \mathrm{~mm}$; fruiting receptacle subglobose, 2-4 $\mathrm{mm}$ diam., rather densely covered with appressed hairs. Seed 1 , lateral, $12-18$ by $10-15$ by $5-7 \mathrm{~mm}$, shiny brown.

Distribution - Western Ecuador (Carchi, Esmeraldas, Imbabura).

Habitat \& Ecology - In non-inundated forest. At elevations of 50-780 m. Flowering: May, September; fruiting: March to May, August, September, December.

Note - Unonopsis esmeraldae is recognized by 1-seeded, mostly transversely ellipsoid monocarps, with 1 laterally attached seed. This monocarp type is quite unusual in Annonaceae. One of the few other examples is Ruizodendron ovale (Ruiz \& Pav.) R.E. Fr.

Selection of other specimens (9) examined:

ECUADOR. Carchi: property of Humberto Rosero, on N side of Río Mira, just above cable crossing, upstream from Lita and downstream from Cachaco, 760-780 m, Boyle et al. 3685 (U). Esmeraldas: Eloy Alfaro, Reserva Ecológica Cotachi-Cayapas, Río Bravo, 50 m, Cornejo S. \& Bonifaz 6218 (MO, U); Bravito, between Estero Mongón and Estero Sabaleta, 400 m, Cornejo S. \& Bonifaz 6489 (AAU, U); Mataje, left margin of Río Mataje, 140 m, J. Jaramillo et al. 13869 (NY, QCA). Imbabura: Lita, $501 \mathrm{~m}$, Acosta-Solís 12280 (F).

\section{Unonopsis floribunda Diels - Plate 4b; Map 10}

Unonopsis floribunda Diels (1924) 137; R.E. Fr. (1937) 258; Spichiger et al. (1989) 129, f. 61. - Type: Tessmann 3262 (holo B; iso F, G, NY, S, US), Peru, Ucayali, Middle Río Ucayali, mouth of Río Pisqui, Cashibo Playa, 19 October 1923.

Tree (2-)5-25(-45) m tall, 10-50(-90) cm diam., often with red exudate; trunk somewhat fissured; young twigs glabrous or sparsely covered with appressed and erect hairs, very soon glabrous. Leaves: petiole 4-8 mm long, 1-2 mm diam.; lamina narrowly elliptic, symmetrical or slightly asymmetrical, $12-30$ by $4-9 \mathrm{~cm}$ (leaf index 2.8-3.8), chartaceous, dull or slightly shiny above, not or slightly verruculose above, densely verruculose below, greyish green to greyish brown above, pale brown to brown below, glabrous or almost so on both sides, base acute, sometimes obtuse, apex acuminate (acumen 5-20 mm long), secondary veins distinct, curved, 9-13 on either side of primary vein, impressed above, angles with primary vein $40-60^{\circ}$, not or weakly loop-forming at right angles, smallest distance between loops and margin 1-3 $\mathrm{mm}$, tertiary veins indistinct, percurrent. Inflorescences on older branches, sometimes among leaves, often lax and panicle-like, or as aggregates of 2 or 3 small panicles, composed of $2-7(-12)$ rhipidia, rarely a compact single rhipidium; peduncle-like base (1-)2-10 mm long; axial internodes 2-8(-15) mm long; rhipidia 1-3-flowered, to 13 flowers in succession; sympodial rachis 3-40 mm long, with internodes $1-5 \mathrm{~mm}$ long (rarely more in fruiting stage), often zigzagging; upper bract at $1 / 3-2 / 3$ from the base of the pedicel, ovate to broadly so, 1-1.5 mm long, outer side densely covered with appressed and erect hairs; pedicels $10-20 \mathrm{~mm}$ long, to $1 \mathrm{~mm}$ diam., fruiting pedicels to $35 \mathrm{~mm}$ long, to $3 \mathrm{~mm}$ diam., densely covered with appressed and erect hairs; flower 
buds depressed globose; sepals basally connate, shallowly ovate-triangular, 1-2 by 2-3 mm, outer side densely covered with appressed and erect hairs; petals cream to creamy yellow in vivo, outer ones very broadly ovate, concave, slightly longitudinally ridged, 7-10 by $6-10 \mathrm{~mm}$, outer side densely covered with appressed and erect hairs, inner ones broadly to very broadly ovate, strongly concave, $6-9$ by $6-10 \mathrm{~mm}$, outer side glabrous except for hairy exposed part; stamens 1.5-2 mm long, connective shield glabrous; carpels 10-20, 1.5-3 mm long, densely covered with appressed hairs, ovule 1, apical, pendent. Monocarps 2-20, green, maturing, yellow, orange to finally black in vivo, brown, or sometimes blackish in sicco, surface somewhat shrivelled in sicco, globose, sometimes broadly ellipsoid, 11-16 by 10-13 mm (in some Peruvian collections $20-30$ by $18-25 \mathrm{~mm}$ ), sparsely covered with appressed and erect hairs to finally glabrous, apex rounded, not apiculate, wall $0.2-0.3\{-2\} \mathrm{mm}$ thick, stipes $6-12$ by $1 \mathrm{~mm}$ (in some Peruvian collections wall in spirit material to $5 \mathrm{~mm}$ thick and stipes to $3 \mathrm{~mm}$ thick); fruiting receptacle subglobose to broadly ellipsoid, 5-6 $\mathrm{mm}$ diam., sparsely covered with appressed and erect hairs to glabrous. Seed 1, apical, 11-13 by $10-13$ by $6-10 \mathrm{~mm}$, brown.

Distribution - Throughout the Amazon Region of Colombia, Peru, Ecuador, Brazil, and Bolivia.

Habitat \& Ecology - In primary, often inundated forest, on clayey to lateritic soil. At elevations of $0-450 \mathrm{~m}$, few collections from Ecuador up to $1200 \mathrm{~m}$. Flowering: throughout the year, but mainly from August to December; fruiting: throughout the year.

Vernacular names - Bolivia: Chocolatillo, Chocolatillo blanco, Huabu midha (Tacana), Meña, Piraquina negro. Brazil: Envira, Envira preta, Envireira. Colombia: Carguero, Foonïdujecu (Muinane), Nagüí. Ecuador: Cara caspi (Quichua), Huasi caspi (Quichua), Kayayeis, Llanta caspimuyu (Quichua), Mati muyo (Quichua), Mongapata

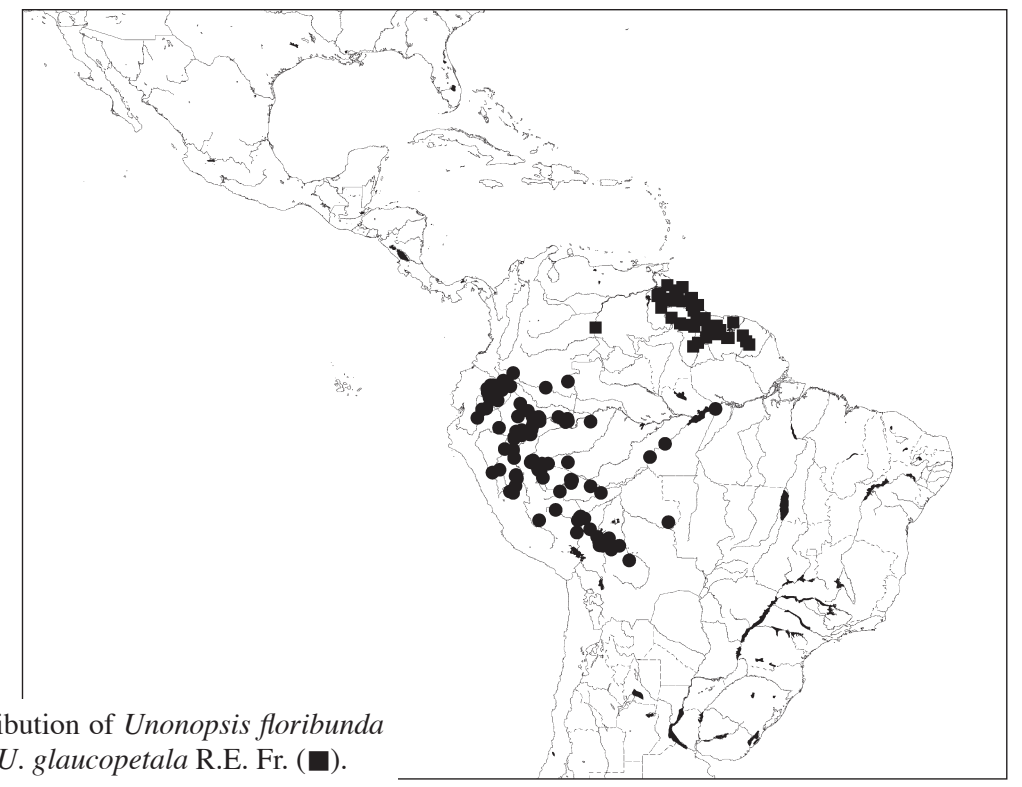

Map 10. Distribution of Unonopsis floribunda Diels $(\bigcirc)$ and $U$. glaucopetala R.E. Fr. 
(Huaorani), Mongapatahue (Huaorani), Sacha carahuasca (Quichua), Yayis. Peru: Carahuasca, Espintana, Hicoja, Hicoja negra, Icoja, Icoja blanca, Icoja colorada, Icoja negra, Tortuga, Tortuga caspi.

Uses - Wood is used as a fuel for smoking raw rubber by Chácobo Indians, Beni, Bolivia (Boom, 1987). Strips of bark serve to tie together poles and beams of houses of the Tacana, Bolivia (DeWalt et al., 1999).

Notes - Unonopsis floribunda, a much-collected species in the Amazon Region, is easily recognized by a combination of almost glabrous leafy twigs and leaves, leaves which are densely verruculose below, a strongly branched, many-flowered inflorescence, and 1-seeded monocarps. It is among the highest trees in Neotropical Annonaceae reaching a height up to $45 \mathrm{~m}$. Its preferred habitat is inundated forests.

Some collections from Peru (Loreto: Indiana and Yanamono) are rather aberrant in having extremely large monocarps and stipes (see description). As all other characters match $U$. floribunda fairly well, we have provisionally included this material in it.

In South America three species stand out because of branched, often lax and paniclelike inflorescences: Unonopsis floribunda, U. glaucopetala, and U. rufescens. This aspect is discussed under U.rufescens.

\section{Unonopsis glaucopetala R.E. Fr. - Fig. 19; Map 10}

Unonopsis glaucopetala R.E. Fr. (1907) 1004; (1937) 257. - Type: Jenman 4252 (holo K; iso BRG, S; fragment S), Guyana, Upper Demerara R., September 1887.

Unonopsis andersonii Sprague ex Hohenkerk (1919) 99. - Type: C.W. Anderson 389 (holo K, 2 sheets), Guyana, NW Distr., Issororo, 27 August 1909.

Tree 2-30 m tall, 10-30 cm diam., often with red exudate; trunk somewhat longitudinally fissured; young twigs densely covered with appressed hairs, soon glabrous. Leaves: petiole 3-8 $\mathrm{mm}$ long, 2-4 $\mathrm{mm}$ diam.; lamina narrowly elliptic to elliptic, sometimes narrowly obovate or obovate, $15-45$ by $5-13 \mathrm{~cm}$ (leaf index 2-3.9), chartaceous, densely verruculose, sometimes shiny above, greyish yellowish brown above, dull yellowish brown below, primary and secondary veins densely to rather densely covered with erect hairs above, otherwise glabrous, sparsely (but primary and secondary veins densely) covered with erect hairs below, base obtuse to acute, apex acuminate (acumen 5-25 mm long), secondary veins distinct, curved, 11-19 on either side of primary vein, impressed above, angles with primary vein $50-65^{\circ}$, loop-forming at right to obtuse angles, smallest distance between loops and margin 1-5 mm, tertiary veins indistinct, percurrent. Inflorescences on older branches or sometimes produced from the trunk, lax and panicle-like (rarely like a double panicle) and $7-15 \mathrm{~cm}$ in overall length, composed of 4-13 rhipidia; peduncle-like base 4-20 mm long; axial internodes 4-15 mm long; rhipidia 3- or 4-flowered, to 15(-20) flowers in succession; sympodial rachis 10-85 $\mathrm{mm}$ long, with internodes (1-)2-10(-13) mm long; upper bract at 1/3-1/2 from the base of the pedicel, broadly to depressed ovate, $1.5-3 \mathrm{~mm}$ long, outer side densely covered with appressed hairs; pedicels 5-18 mm long, c. $1 \mathrm{~mm}$ diam., fruiting pedicels to $3.5 \mathrm{~mm}$ diam., densely covered with appressed hairs; flower buds very broadly to depressed ovoid; sepals fused for about $2 / 3$ of their length, depressed to very depressed ovate, $1-1.5$ by $1.5-4 \mathrm{~mm}$, outer side densely to sparsely covered with appressed hairs; petals pale green in vivo, outer ones broadly ovate, concave, $4-6\{-8\}$ by $4-5\{-7\} \mathrm{mm}$, 


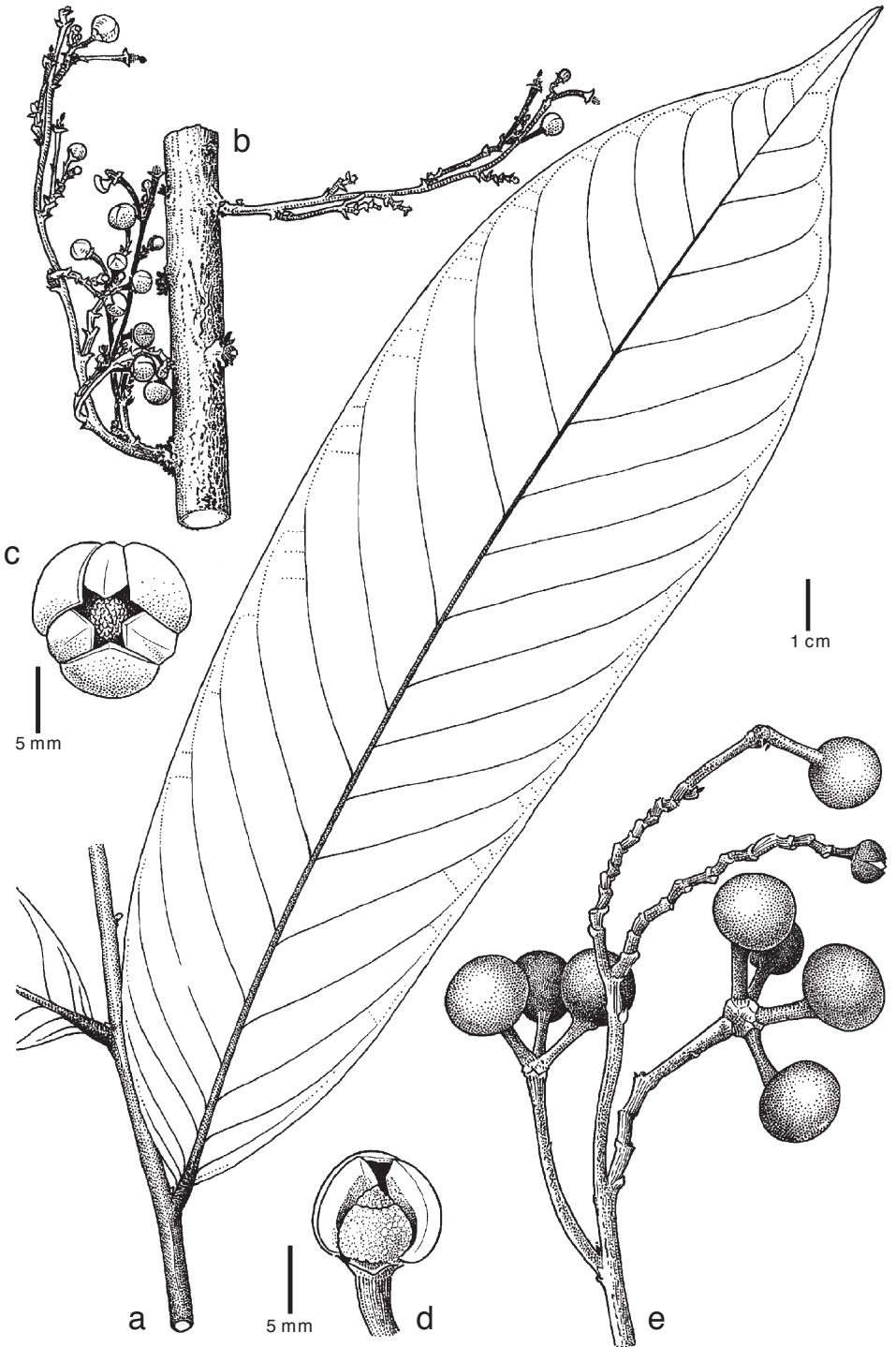

Fig. 19. Unonopsis glaucopetala R.E. Fr. a. Leafy branch; b. inflorescence; c. flower seen from above, showing outer and inner petals, and carpels; d. dissected flower showing 1 outer petal and 2 inner petals, stamens, and carpels; e. infructescence. (a, e: Van Andel et al. 1917, U; b-d: Van Andel et al. $885, \mathrm{U}) .-$ Drawing by H. Rypkema.

outer side densely covered with appressed hairs, inner ones ovate to broadly so, concave, $4-5\{-7\}$ by $3-4\{-8\} \mathrm{mm}$, outer side glabrous, but keel sparsely hairy; stamens 1-1.5 mm long, connective shield glabrous; carpels c. 20, c. $1 \mathrm{~mm}$ long, with 4 longitudinal rows of appressed hairs, ovule 1, lateral near the top. Monocarps 4-15, green, maturing black in vivo, very dark reddish brown to black in sicco, globose to 
transversely broadly ellipsoid, $10-14$ by $11-15 \mathrm{~mm}$, sometimes wrinkled, glabrous, apex rounded, not apiculate, wall $1-2\{-3\}$ mm thick, stipes $4-15$ by $1.5-2.5 \mathrm{~mm}$; fruiting receptacle transversely ellipsoid to transversely broadly ellipsoid, $3.5-8 \mathrm{~mm}$ diam., densely covered with appressed hairs. Seed 1 , lateral, $9-13$ by $10-12$ by $8-11$ $\mathrm{mm}$, very dark reddish brown.

Distribution - Venezuela (Bolívar, Delta Amacuro) and the 3 Guianas.

Habitat \& Ecology - In primary or semidisturbed forest, near rivers or creeks, in marshes, often in Mora or Greenheart forest, on sandy, loamy, or clayey soil. At elevations of $0-800 \mathrm{~m}$. Flowering and fruiting: throughout the year, but mainly from July to November.

Vernacular names - French Guiana: Azo udu (Boni), Tapïseipio (Carib). Guyana: Arara (Arawak), Arara yariyari (Arawak), Baeda, Black hue yariyari (Arawak), Black yariyari (Arawak), Karishiri (Arawak), Rough skin arara (Arawak). Suriname: Arara (Arawak), Awigue, Panta (Sranang), Peperhout (Surinamese Dutch), Pepre udu (Sranang), Pepre sowtu (Sranang), Pikapika (Sranang), Yariyari (Sranang). Venezuela: Yara Yara amarilla, Yara Yara negra, Yara Yara negra grande.

Note - Unonopsis glaucopetala typically has branched and many-flowered inflorescences. Unonopsis floribunda and $U$. rufescens are other species with similar features. For the differences see under $U$.rufescens.

\section{Unonopsis guatterioides (A.DC.) R.E. Fr. - Plate 2a, 4c, d; Map 11}

Unonopsis guatterioides (A.DC.) R.E. Fr. (1937) 241. - Uvaria guatterioides A.DC. (1832) 202. - Type: Unknown collector s.n. (holo G, 2 sheets), French Guiana, without location, 1831.

Annona peduncularis Steud. (1843) 754. - Lectotype (here designated): Hostmann \& Kappler 1116, ed. Hohenacker (holo K; isolecto BM, G, MO, P, S, U), Suriname, without location and year of collection.

Unonopsis angustifolia (Benth.) R.E. Fr. (1900) 26, syn. nov. - Trigynaea angustifolia Benth. (1860) 70. - Type: Spruce 2567 (holo K; iso BR, C, E, FHO, G, K, LE), Brazil, Amazonas, Rio Vaupés ('Rio Vaupés, gapó [= igapó]'), September 1851. The specimens from C, E, G, and LE are erroneously labelled 'Spruce 2576'.

Unonopsis lindmanii R.E. Fr. (1900) 27, t, 4, f. 3-8, syn. nov.; (1937) 244. - Type: Regnell III248 (lecto S (Maas et al., 1994); isolecto B, BR, C, K, M, P, S, U, US), Brazil, Minas Gerais, Uberava, 10 November 1848.

Unonopsis matthewsii (Benth.) R.E. Fr. (1900) 28, syn. nov. - Trigynaea matthewsii Benth. (1860) 69. - Type: Matthews 1421 (holo K, 2 sheets; iso E, OXF, P; fragment S), Peru, San Martín, Tarapoto, 1835.

Unonopsis antillana (Rolfe) R.E. Fr. (1900) 28, syn. nov. - Trigynaea antillana Rolfe (1893) 235. - Lectotype (here designated): H.H. \& G.W. Smith 1539 (holo K), Anse Mahant, below $330 \mathrm{~m}$ ('1000 ft'), St. Vincent, March 1890; syntype: H.H. \& G.W. Smith 1359 (syn K), St. Vincent, $330-630 \mathrm{~m}$.

Unonopsis boliviensis (Britton) R.E. Fr. (1900) 28, syn. nov. - Trigynaea boliviensis Britton (1889) 14. - Type: Rusby 1253 (holo NY; iso G, GH, K, P, US, WIS), Bolivia, Beni-Pando, junction of Río Beni and Río Madre de Dios, August 1886.

Unonopsis grandis (Benth.) R.E. Fr. (1900) 28, syn. nov. - Trigynaea grandis Benth. (1860) 70. - Type: Spruce 3163 (holo K; iso BR, FHO, G, K, NY, P), Venezuela, Amazonas, Río Casiquiare, ('in ripis Casiquiaris inferioris'), November 1853.

Unonopsis guaraya Herzog (1909) 52, syn. nov. - Type: Herzog 405 (holo Z), Bolivia, Santa Cruz, Río Blanco, San Pedro de Cururú ('Cururú'), 140 m, August 1907.

Unonopsis buchtienii R.E. Fr. (1928) 247, syn. nov. - Type: Buchtien 2048 (holo S; iso GH, NY), Bolivia, La Paz, San Carlos de Mapiri, 750 m, September 1907. 
Unonopsis williamsii R.E. Fr. (1937) 238, f. 6, t. 1, syn. nov. - Type: Ll. Williams 3449 (holo F, 2 sheets; iso F), Peru, Loreto, Upper Río Itaya, San Antonio, 145 m, 1 September 1929.

Unonopsis guatterioides (A.DC.) R.E. Fr. forma elongata R.E. Fr. (1937) 242. - Syntypes: $B W$ 4436 (MO, S, U, 2 sheets), Suriname, Forest Reserve Watramiri, 28 October 1919; BW 5574 (U), Suriname, Forest Reserve Watramiri, 19 December 1921; Kegel 1362 (GOET), Suriname, Saramaca R., Maripaston, May 1846.

Unonopsis gracilis R.E. Fr. (1937) 247, f. 5f-h, syn. nov. - Type: Ll. Williams 4188 (holo F; iso F), Peru, Loreto, Fortaleza, Yurimaguas, 155-210 m, 28 October 1929.

Unonopsis obovata R.E. Fr. (1937) 249, f. 5a-e, syn. nov. - Type: Killip \& Smith 27985 (holo F; iso NY, US; fragment S), Peru, Loreto, Lower Río Huallaga, Yurimaguas, 135 m, 23 August to 7 September 1929.

Tree or shrub 1-10(-25) $\mathrm{m}$ tall, 1-20(-35) cm diam.; young twigs densely or rarely sparsely covered with appressed to erect hairs, soon glabrous. Leaves: petiole 1-7 mm long, 2-3 mm diam.; lamina generally narrowly elliptic to narrowly obovate, symmetrical or slightly asymmetrical to falcate, $6-33$ by $2-10 \mathrm{~cm}$ (leaf index 1.9-4.5), chartaceous, rather densely to densely verruculose, shiny or dull above, brown or greyish olive on both sides, primary and sometimes secondary veins sparsely to rather densely covered with appressed to erect hairs above, otherwise glabrous, sparsely to rather densely covered with appressed to erect hairs, particularly along primary and secondary veins, below, base acute to obtuse, very rarely cordate, apex acuminate (acumen 5-40 mm long), secondary veins distinct, curved, 8-15 on either side of primary vein, flat to impressed above, angles with primary vein $40-50(-60)^{\circ}$, loop-forming at right to obtuse angles, smallest distance between loops and margin 1-5 mm, tertiary veins indistinct or distinct, percurrent. Inflorescences among leaves, sometimes on older branches, rarely terminal or seemingly terminal due to abortion of vegetative growth tip, compact or sometimes sublax, composed of 1-3(-5) rhipidia, often only 1 rhipidium; peduncle-like base $0-3 \mathrm{~mm}$ long; axial internodes $1(-3) \mathrm{mm}$ long; rhipidia 1- or 2- (or 3-)flowered, to sometimes 8 flowers in succession; sympodial rachis to $5 \mathrm{~mm}$ long; upper bract at 1/8-1/2 from the base of the pedicel, broadly to depressed ovate, $0.5-2 \mathrm{~mm}$ long, outer side rather densely to densely covered with appressed hairs; pedicels 5-30 $\mathrm{mm}$ long, $0.5-1.5 \mathrm{~mm}$ diam., fruiting pedicels to $50 \mathrm{~mm}$ long, to $2.5 \mathrm{~mm}$ diam., densely or rarely sparsely covered with appressed to erect hairs; flower buds very broadly to depressed ovoid; sepals free, sometimes basally connate, broadly to shallowly ovate-triangular, 1-2 by $1-4 \mathrm{~mm}$, outer side densely to rather densely covered with appressed hairs; petals cream to white in vivo, outer ones ovate to broadly ovate, slightly concave, 5-9 by 4-9 mm, outer side densely covered with appressed hairs, inner ones ovate to broadly ovate, strongly concave, $5-9$ by $3-8 \mathrm{~mm}$, outer side glabrous except for hairy exposed part; stamens 1-2 mm long, connective shield glabrous; carpels 2-10, 1-2 mm long, densely covered with appressed, whitish hairs, ovules 1-5, lateral. Monocarps 1-15, green, orange to red, maturing black in vivo, dark reddish brown in sicco, ellipsoid, transversely broadly ellipsoid, or globose, sometimes constricted, 6-25(-35) by 6-15(-20) $\mathrm{mm}$, rather densely to sparsely covered with erect to appressed hairs to finally glabrous, apex rounded, apiculate (apiculum $0.1-0.5$ $\mathrm{mm}$ long) or not, wall $0.2-0.5\{-2\} \mathrm{mm}$ thick, stipes $3-13$ by $1-3 \mathrm{~mm}$; fruiting receptacle transversely ellipsoid to transversely broadly ellipsoid, 3-7 $\mathrm{mm}$ diam., densely to sparsely covered with appressed and erect hairs. Seeds $1-6$, lateral, 7-13 by 7-12 by 3-6 $\mathrm{mm}$, dark reddish brown. 


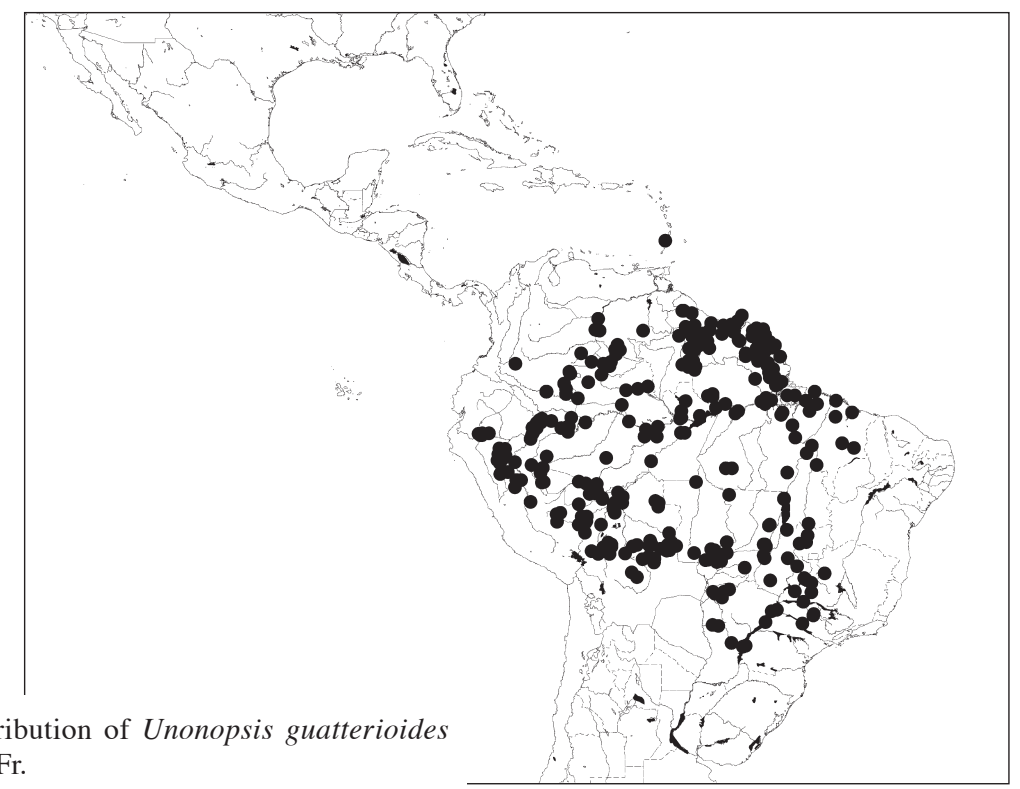

Map 11. Distribution of Unonopsis guatterioides (A.DC.) R.E. Fr.

Distribution - Lesser Antilles (St. Vincent), the Amazon Region of Colombia, Venezuela, Peru, and Bolivia, and throughout Brazil, a single collection from Paraguay, and in Guyana, Suriname, and French Guiana.

Habitat \& Ecology - In periodically inundated forest (gallery forest, tahuampa, or igapó), sometimes in non-inundated forest, on clayey to sandy soil. At elevations up to 400(-875) m. Flowering: mainly March to December; fruiting: throughout the year.

Pollination - Flower visits by Euglossine bees (Eulaema bombiformis) have been observed in the Reserva Ducke, near Manaus. The male bees appeared to collect odour on flowers in both pistillate and staminate stages. Other visits recorded were by Meliponine bees collecting pollen and Chrysomelid beetles feeding on the surface cells of the petals (Carvalho \& Webber, 2000; Silberbauer-Gottsberger et al., 2003).

Vernacular names - Bolivia: Bilibëte (Yuracare), Čocolate-dmbwér (Sirionó), Chocolatillo, Laurel, Midha dhahua (Tacana), Monte-chirimoya, Piraquina, Xahuisi (Chácobo). Brazil: Araticum, Ariticum, Ata do igapó, Atinha, Cundurú, Envira, Envira da várzea, Envira do caiso, Envira do igapó, Envira preta, Envira preta do igapó, Envira surucucu, Envira surucucu da várzea, Invira, Mejo de porco, Mutambi, Muxiba, Pindaíba, Pindaíba branca, Pindaíba preta. Colombia: Cajao dujecu (Muinane), Duguecu (Muinane), Foonïdujecu de hoja pequeña (Muinane), Sïfcó (Andoque), Weé-goo-moo (Makuna),Yáw-töt (Makuna). French Guiana: Ewokpokan (Wayana), Maman yawée de l'eau (Creole), Mama yawé (Creole), Mama yowé (Creole), Miret (Palikour), Pepe nanga saotou (Sranang), Pepre nanga sowtu (Sranang), Pina’’ (Wayãpi). Guyana: Rough skin arara. Peru: Achuana, Anonilla, Bara, Bara caspi, Barra, Čiwánim yais, Copal, Espintana, Hicoja, Hicoja amarilla, Hicoja negra, Hoja hedionda, Icoja, Namakia yais, Uchi yais, Yais, Ycoje. Suriname: Akare pomëirjë (Carib), Akare pomi' irï (Carib), Kaiman pepre (Sranang), Kwaranapoiballi (Arawak), Laagland kleinbladige yariyari (Surinamese 
Dutch), Murewa-rang (Carib), Panta (Sranang), Pepre nanga sowtu (Sranang), Watertamarinde (Surinamese Dutch), Watrapanta (Sranang), Yariyari (Sranang), Yeseredan unirefodikoro (Arawak).Venezuela: Majãúe ${ }^{\sim}$, Palo salao, Pojolóa.

Notes - Unonopsis guatterioides is recognized by relatively small flowers, slender pedicels, and a generally depauperate and often 1-flowered inflorescence, in combination with several-seeded monocarps.

Unonopsis guatterioides is by far the most variable and problematical species in the genus, and it certainly needs more work in the field as well as in the herbarium.

Several species are now treated as synonymous with $U$. guatterioides, some of them we would like to mention here. Unonopsis angustifolia is considered by us as a largeleaved form of $U$. guatterioides. Unonopsis grandis is merely a thick-leaved form of $U$. guatterioides. Unonopsis gracilis and U. obovata, both from Amazonian Peru, slightly differ from $U$. guatterioides by almost glabrous leafy twigs, rather narrow leaves and (in some specimens) quite large monocarps reaching a length of up to 35 $\mathrm{mm}$. Several intermediates made it problematical to keep them separate from $U$. guatterioides, though, and therefore we included the two species. In Central Brazil hairy forms of $U$. guatterioides are quite common, and these have been treated as a distinct species $U$. lindmanii. They fall, nevertheless, within the variation pattern of $U$. guatterioides as a whole.

18. Unonopsis hammelii G.E. Schatz \& Maas, spec. nov. - Fig. 20; Plate 5a, b; Map 12

Species pilis crispis ferrugineis patentibus, inflorescentiis plerumque compactis pluriflorisque, carpellis pro ratione multis distincta. - Typus: Hammel 11608 (holo CR; iso DUKE, F, MO, WIS), Costa Rica, Heredia, Finca La Selva, OTS Field Station on Rio Puerto Viejo, just E of its junction with Río Sarapiquí, 100 m, 7 April 1982.

Tree 10-20 m tall, 15-45 cm diam.; young twigs densely covered with erect, curly, brown hairs, soon glabrous. Leaves: petiole 5-8 $\mathrm{mm}$ long, 1-2 $\mathrm{mm}$ diam.; lamina generally narrowly elliptic, symmetrical to slightly asymmetrical, $12-22$ by $4.5-8$ $\mathrm{cm}$ (leaf index 2.3-3.6), coriaceous, densely or not verruculose, shiny above, greyish brown, blackish brown to greenish above, greyish brown to brown below, glabrous above, rather densely to sparsely covered with erect, curly, brown hairs below, base acute to obtuse, apex shortly acuminate (acumen 5-10 mm long), secondary veins distinct, curved, 10-13 on either side of primary vein, impressed above, angles with primary vein $30-45^{\circ}$, loop-forming at obtuse angles, smallest distance between loops and margin 1-2 mm, tertiary veins distinct, percurrent. Inflorescences on older branches, rarely among leaves; compact or rarely sublax, composed of 2-5 (or possibly more) rhipidia, axial internodes $<1-2 \mathrm{~mm}$ long; rhipidia 1- or 2-flowered, to c. 7 flowers in succession; sympodial rachis to $4 \mathrm{~mm}$ long; upper bract at 1/8-1/3 from the base of the pedicel, broadly ovate-triangular, 1.5-2 $\mathrm{mm}$ long, outer side densely covered with erect, curly, brown hairs; pedicels 10-15 mm long, 1-1.5 mm diam., densely covered with erect, curly, brown hairs, fruiting pedicels to $30 \mathrm{~mm}$ long, to $3 \mathrm{~mm}$ diam., densely covered with erect, curly, brown hairs; flower buds subglobose; sepals basally connate, shallowly ovate-triangular, $1-2$ by $3-4 \mathrm{~mm}$, outer side densely covered with erect, curly, brown hairs; petals cream, creamy orange, or yellow in vivo, outer ones 


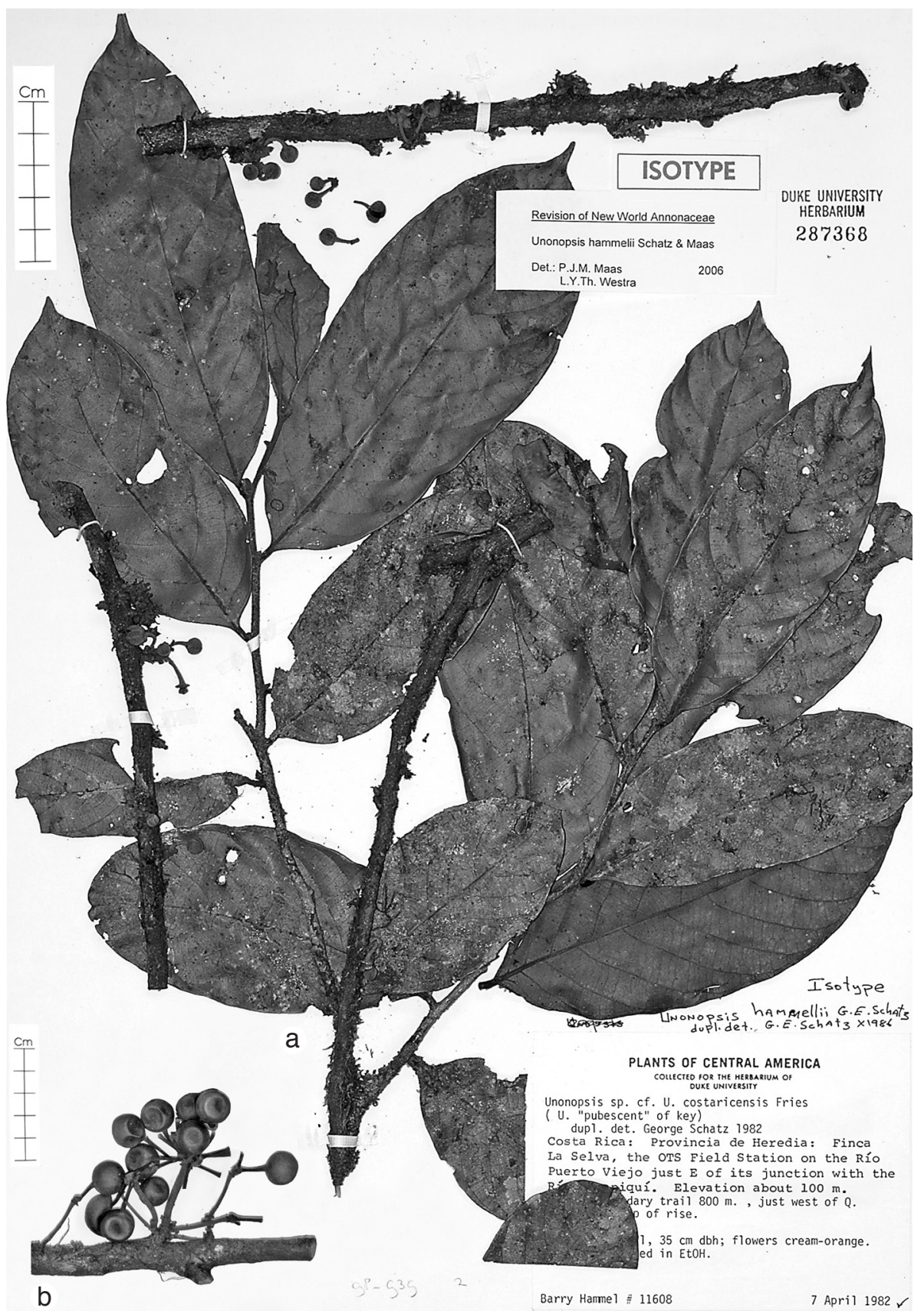

Fig. 20. Unonopsis hammelii G.E. Schatz \& Maas. a. Flowering twig; b. part of fruiting twig (a: Hammel 11608, iso DUKE; b: Hammel 9423, DUKE). 


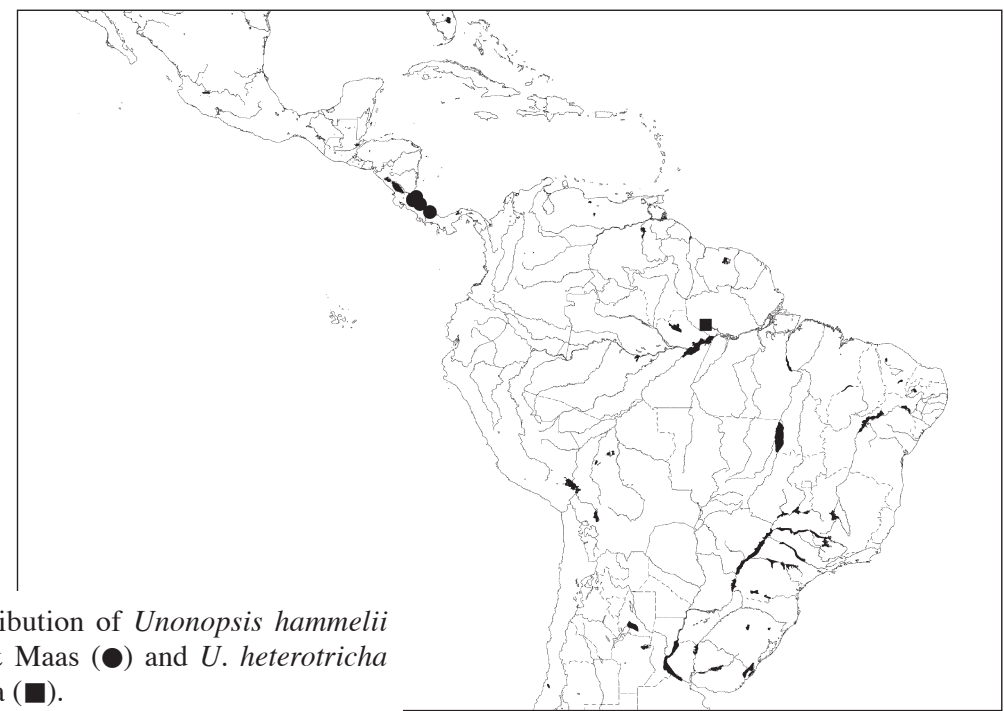

Map 12. Distribution of Unonopsis hammelii G.E. Schatz \& Maas $(\bullet)$ and $U$. heterotricha Maas \& Westra (ם).

broadly ovate, slightly concave, $5-6\{-9\}$ by $5-6\{-8\} \mathrm{mm}$, outer side densely covered with erect, curly, brown hairs, inner ones broadly ovate, strongly concave, $4\{-6\}$ by $4-4.5\{-5\} \mathrm{mm}$, outer side glabrous except for hairy exposed part; stamens 1-1.5 mm long, connective shield glabrous; carpels 50-60, 1-2 mm long, densely covered with erect, whitish hairs, ovules 1, lateral. Monocarps 5-40, glaucous or greyish green in vivo, brownish in sicco, globose, $13-18 \mathrm{~mm}$ diam., rather densely to sparsely covered with erect, curly, brown hairs, apex rounded, not apiculate, wall c. $1 \mathrm{~mm}$ thick, stipes $11-15$ by $1-1.5 \mathrm{~mm}$; fruiting receptacle depressed to broadly ovoid, $3-7$ by $3-10 \mathrm{~mm}$, densely covered with erect, curly, brown hairs. Seeds 1 or 2, lateral, $8-11$ by $8-9$ by 2-5 mm, dark brown (seeds as far as seen in U material aborted).

Distribution - Costa Rica (Heredia, Limón) and Panama (Bocas del Toro).

Habitat \& Ecology - In forest. At elevations of 0-400 m. Flowering: February, April, May, October; fruiting: August.

Note - Unonopsis hammelii (honouring our esteemed colleague Dr. Barry E. Hammel, Missouri Botanical Garden, St. Louis, MO, and InBio, Costa Rica) is recognized by a dense indument of erect, curly, brown hairs on most of its parts, a compact and many-flowered inflorescence, and a relatively high number of carpels.

Other specimens examined:

COSTA RICA. Heredia: Magsasay, 150 m, Gentry et al. 71762A (MO); Finca La Selva, OTS Field Station on the Río Puerto Viejo, just E of its junction with Río Sarapiquí, South Boundary, on slope of Quebrada El Salto, 100 m, Hammel 9423 (DUKE, F, MO); Reserva Ecológica Bijagual de Sarapiquí, $9 \mathrm{~km}$ N of La Virgén, 350 m, Maas et al. 9430 (INB, U). Limón: Cantón de Pococi, R.N.F.S. Barra del Colorado, Llanura de Tortuguero, Sardinas, 15-20 m, Araya et al. 247 (F, INB); Cordillera de Talamanca, Matina, intersección between Río Barbilla and Quebrada Cañabral, 100-200 m, G. Herrera et al. 2169 (INB); Matina, Parque Nacional Barbilla, Sendero Cerro Azul, Colonia Puriscaleňa, 400 m, Mora \& Rojas 823 (INB, MO).

PANAMA. Bocas del Toro: road from Almirante to Changuinola, side road to Ojo de Agua, $500 \mathrm{~m}$, Maas et al. 9522 (INB, NY, PMA, SCZ, U). 
19. Unonopsis heterotricha Maas \& Westra, spec. nov. - Fig. 21; Map 12

Species ramulis novellis heterotrichis, foliis base cordatis et breviter petiolatis, monocarpiis brevibus distincta. - Typus: Campbell et al. P22532 (holo INPA; iso K, MO, NY, U, US), Brazil, Pará, Rio Trombetas, 4 km S of Cachoeira Porteira, 6 June 1974.

Tree c. $8 \mathrm{~m}$ tall; young twigs densely covered with erect, tiny hairs, interspersed with some erect, needle-like hairs up to $1.5 \mathrm{~mm}$ long, soon glabrous. Leaves: petiole 2-3 $\mathrm{mm}$ long, 1-1.5 mm diam.; lamina generally narrowly elliptic to narrowly obovate, $14-18$ by $5-7 \mathrm{~cm}$ (leaf index $2.3-3.2$ ), chartaceous, densely verruculose, dull and greyish brown above, brown below, sparsely covered with appressed hairs along primary vein above, soon glabrous, sparsely covered with appressed hairs along primary and secondary veins below, base shallowly cordate to broadly rounded, apex bluntly

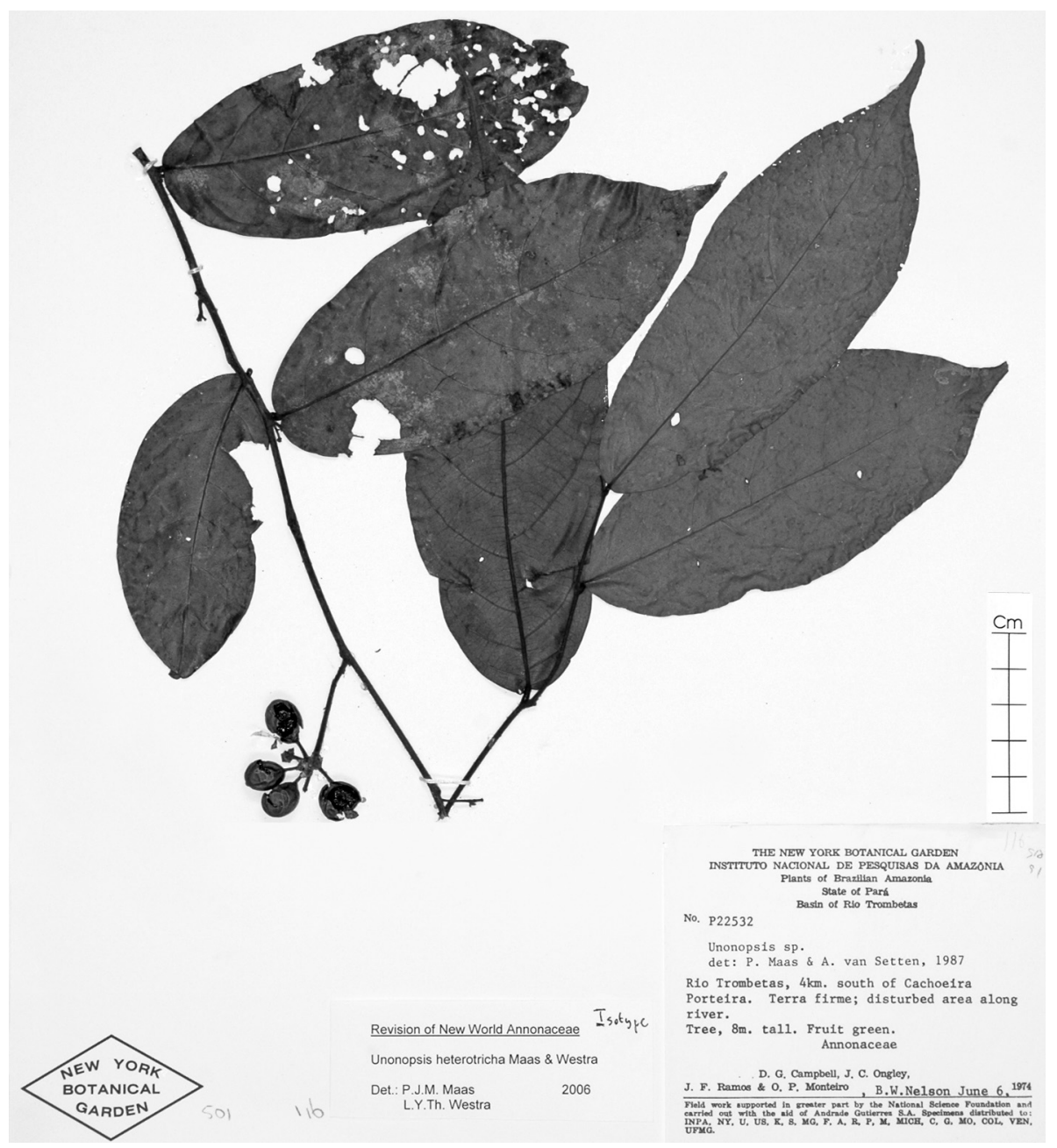

Fig. 21. Unonopsis heterotricha Maas \& Westra. Fruiting twig (Campbell et al. P22532, iso NY). 
acuminate (acumen 10-20 mm long), secondary veins distinct, curved, 6-11 on either side of primary vein, raised above, angles with primary vein $60-65^{\circ}$, loop-forming at obtuse to right angles, smallest distance between loops and margin 3-7 mm, tertiary veins distinct, reticulate. Inflorescences among leaves, lax (or occasionally double), composed of (1 or) 2 rhipidia; peduncle-like base $0-10 \mathrm{~mm}$ long; axial internodes 1-10 mm long; rhipidia usually 1-flowered, to c. 5 flowers in succession, sympodial rachis $\leq 2 \mathrm{~mm}$ long; upper bract at c. $1 / 3$ from the base of the pedicel, broadly ovatetriangular, 1-1.5 mm long, outer side densely covered with appressed hairs; fruiting pedicels 10-30 mm long, c. $1 \mathrm{~mm}$ diam., densely covered with appressed hairs; flower buds not seen; sepals basally connate, shallowly ovate-triangular, $1-1.5$ by $1.5-2 \mathrm{~mm}$, outer side densely covered with appressed hairs; petals, stamens, and carpels not seen. Monocarps 15-20, green in vivo, pale brown and shrivelled in sicco, ellipsoid, 9-12 by $6-7 \mathrm{~mm}$, sparsely covered with appressed hairs, soon glabrous, apex rounded, wall $0.1-0.2 \mathrm{~mm}$ thick, stipes $4-7$ by $1 \mathrm{~mm}$; fruiting receptacle depressed ovoid, 3 by $4-5$ $\mathrm{mm}$, densely covered with appressed and erect brown hairs. Seed 1, basal, 8-10 by 6-7 by $4-6 \mathrm{~mm}$, reddish brown.

Distribution - Brazil (Pará).

Habitat \& Ecology - In non-inundated, disturbed forest, along river. Elevation unknown. Flowering: unknown; fruiting: June. Only known from the type collection.

Note - Unonopsis heterotricha is recognized by a combination of small leaves with a cordate base and small, ellipsoid monocarps. A quite distinctive feature are the long hairs intermixed with shorter pubescence on the leafy twigs, which is denoted by the epithet 'heterotricha'.

\section{Unonopsis longipes Maas \& Westra, spec. nov. - Fig. 22; Map 13}

Unonopsi sessilicarpae proxima sed pedicellis longioribus et monocarpiis distincte stipitatis differt. - Typus: Warner 301 (holo MO; iso COL, F, HUA, NY), Colombia, Chocó, Cabo Corrientes, Río Parguerra, at the foot of Mt Janano, 50-100 m, 27 May 1974.

Tree 2-10 m tall, to $14 \mathrm{~cm}$ diam.; young twigs densely covered with appressed and erect, long-persistent, hairs. Leaves: petiole 3-5 mm long, 2-3 mm diam.; lamina generally narrowly elliptic to narrowly obovate, symmetrical, rarely slightly asymmetrical, $20-30$ by $7.5-12 \mathrm{~cm}$ (leaf index 2.1-2.8), chartaceous, sparsely to rather densely verruculose, dull above, pale brown above, pale greenish brown below, primary vein densely covered with appressed hairs above, otherwise glabrous, rather densely covered with erect and appressed hairs below, base obtuse to cordate, apex acuminate (acumen 5-30 mm long), secondary veins distinct, curved, 12-14 on either side of primary vein, slightly impressed above, angles with primary vein c. $45^{\circ}$, loop-forming at right angles, smallest distance between loops and margin 1-2 mm, tertiary veins distinct, percurrent. Inflorescences among leaves, sometimes seemingly terminal due to abortion of main vegetative axis, or on older branches, compact or subcompact, composed of 1 or 2 rhipidia (one often abortive), mostly sessile, axial internodes $<1-5(-12) \mathrm{mm}$ long; rhipidia 1- or 2-flowered; upper bract at 1/6-1/3 from the base of the pedicel, broadly ovate, $2-3 \mathrm{~mm}$ long, outer side densely covered with appressed and erect hairs; pedicels 15-30 mm long, 1-2 mm diam., fruiting pedicels to $50 \mathrm{~mm}$ long, densely covered with appressed and erect hairs; flower buds subglobose; sepals free, shallowly 


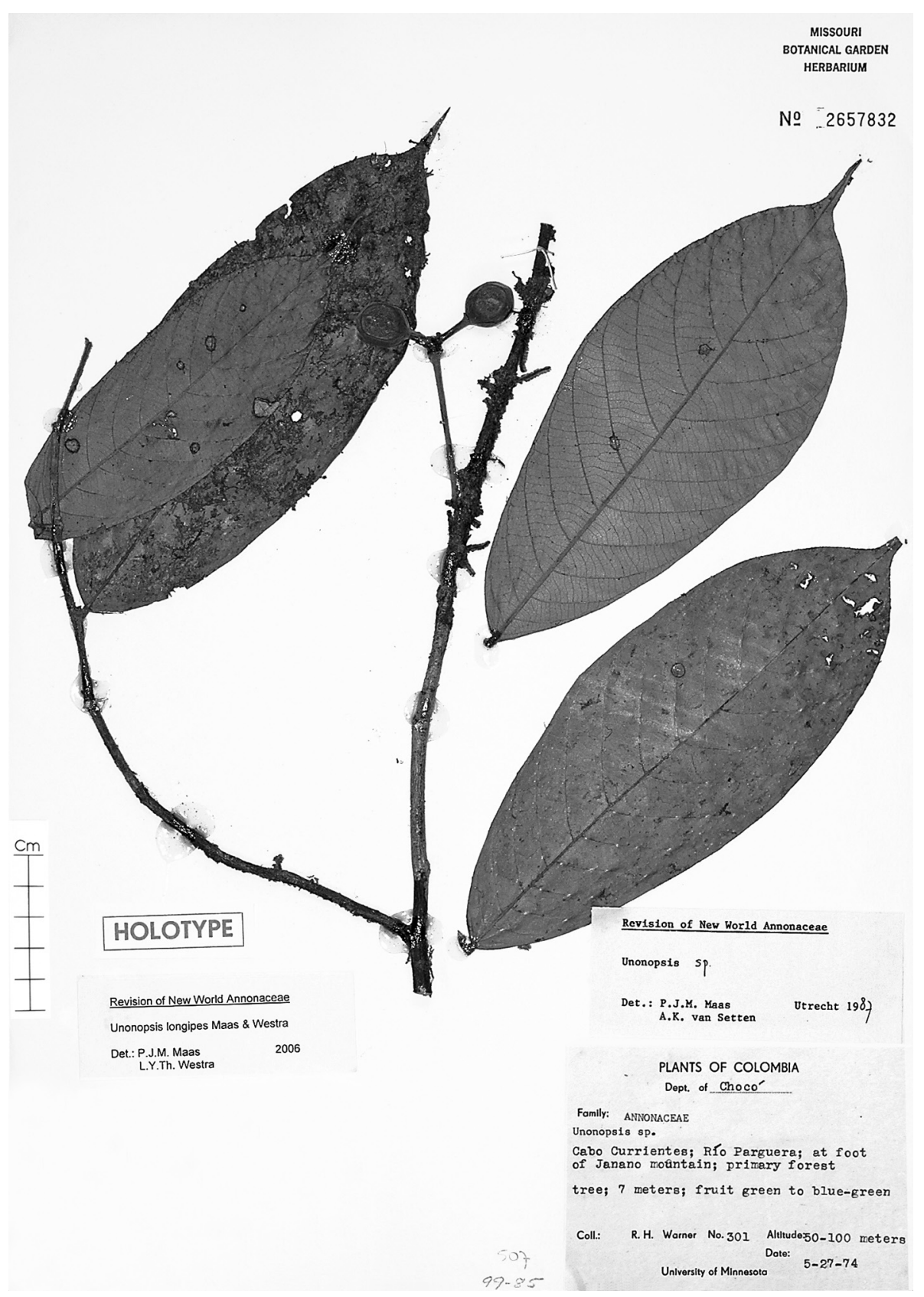

Fig. 22. Unonopsis longipes Maas \& Westra. Fruiting twig (Warner 301, holo MO). 
ovate-triangular, $1.5-2$ by $3 \mathrm{~mm}$, outer side densely covered with appressed and erect hairs; petals cream to yellow in vivo, outer ones broadly ovate, slightly concave, $8-10$ by $7-8 \mathrm{~mm}$, outer side densely covered with appressed and erect hairs, inner ones broadly ovate, strongly concave, 6-7 by 5-6 mm, glabrous except for hairy exposed part; stamens 1.5-2 mm long, connective shield glabrous; carpels 5-10, 1.5-3 mm long, densely covered with appressed and erect hairs, ovules 3, lateral. Monocarps $5-10$, green to blue-green in vivo, greyish brown to greyish black in sicco, ellipsoid to globose, $15-17$ by $12-15 \mathrm{~mm}$, sparsely covered with appressed and erect hairs, apex rounded, not apiculate, wall c. $0.2 \mathrm{~mm}$ thick, stipes $6-12$ by $1-2 \mathrm{~mm}$; fruiting receptacle ovoid to broadly ovoid, $3-5$ by $3-5 \mathrm{~mm}$, densely covered with appressed and erect hairs. Seeds $1-3$, lateral, $11-13$ by $8-11$ by $5-6 \mathrm{~mm}$, brown.

Distribution - Panama (San Blas) and Colombia (Antioquia, Chocó).

Habitat \& Ecology - In non-inundated, primary forest. At elevations of 50-1070 m. Flowering: February, June to August; fruiting: February, May, July to December.

Notes - Unonopsis longipes looks similar to the Colombian U. sessilicarpa, but it differs by its much longer pedicels (15-50 vs 4-20 mm) and stipes (6-12 vs 2-3 $\mathrm{mm})$.

Two specimens from Panama possibly belong to this species judged by their leaves (cordate base) and monocarps, namely McPherson \& Aranda 10153 (U), from Bocas del Toro, above Chiriquí Grande, $300 \mathrm{~m}$ and McPherson 8001 (MO) from Veraguas, along Río Gatu, above Chitra Bajo, NW of Laguna Yeguada, $650 \mathrm{~m}$. They differ from U. longipes by somewhat narrower leaves $(15-20$ by $4-5.5 \mathrm{~cm})$ and an almost glabrous, verruculose lower leaf side. McPherson \& Aranda 10153 shares the relatively long pedicels (15-20 mm long) and stipes (8-10 mm long) with U. longipes. McPherson 8001 is aberrant by having shorter pedicels (c. $10 \mathrm{~mm}$ long) and short stipes (2-3 mm long) and, in this respect, seems to come more close to the Colombian U. sessilicarpa.

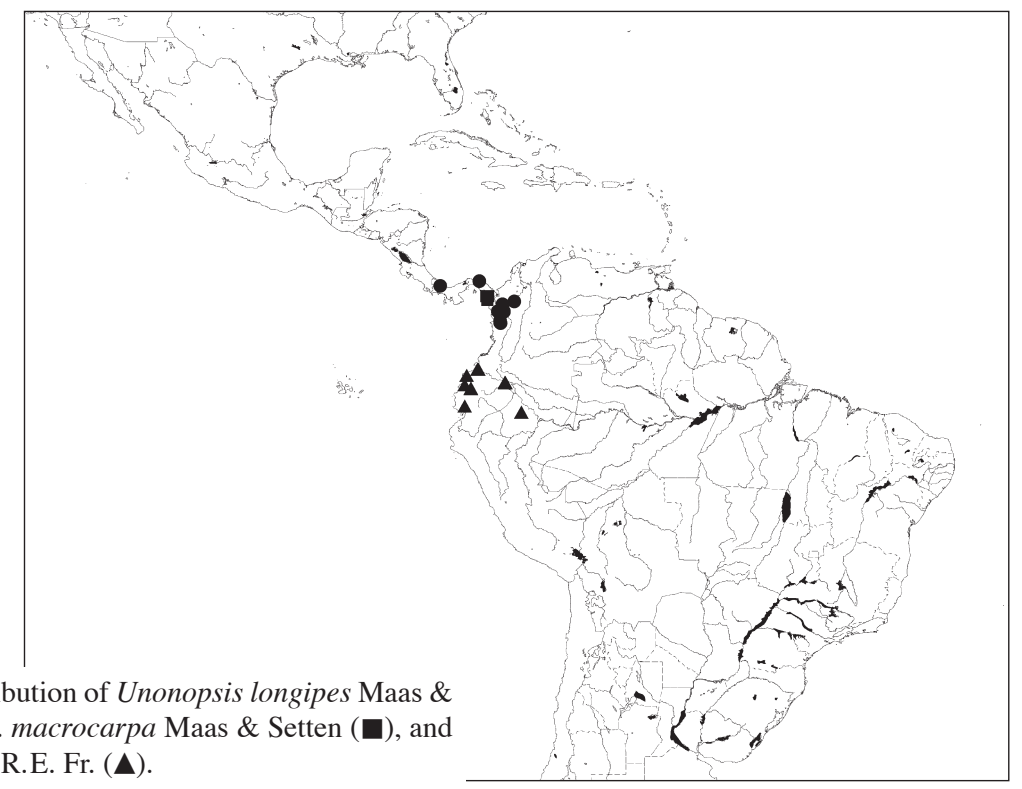

Map 13. Distribution of Unonopsis longipes Maas \& Westra (○), U. macrocarpa Maas \& Setten (ם), and U. magnifolia R.E. Fr. (A). 
Selection of other specimens (11) examined:

PANAMA. San Blas: Cordillera opposite Isla Narganá, quebrada affluent of Río Diablo, 65 m, Galdames et al. 1538 (DUKE, MO, U); between Quebrada de Río Diablo and Cordillera de Cerro Ibedon, 200-350 m, H. Herrera et al. 1478 (U).

Colombia. Antioquia: Mun. Tarazá, Corregimiento El 12, road El 12 to Barroblanco, Hacienda Las Mercedes, potrero San Juan, 180-310 m, Callejas et al. 5430 (HUA, MO, NY, U); Parque Nacional Natural 'Las Orquídeas', left bank of Río Venados, 1070 m, Cogollo et al. 3390 (MO); Mun. Frontino, road between Nutibara and la Blanquita, region of lower Río Murrí, c. 28 km from Nutibara, 960 m, MacDougal et al. 3805 (HUA, MO, U). Chocó: road from km 27 (2 km S of Yuto) of the Quibdó-Istmina Road to Lloró, 100 m, Gentry \& Brand 36957 (MO, NY, U); Mun. Vigia del Fuerte, Yarapetó, Río Yarapetó, 18 m, J.A. Gómez 566 (HUA); left side of road from Quibdó to Guayabal, Sánchez S. et al. 354 (U).

\section{Unonopsis macrocarpa Maas \& Setten - Map 13}

Unonopsis macrocarpa Maas \& Setten, in Maas et al. (1988) 265, f. 23. - Type: Folsom et al. 4324 (holo MO), Panama, Darién, Cerro Pirre, ridge top near Rancho Plastico, 1200 m, 10-20 July 1977.

Tree 5-12 m tall, 13-15 cm diam., sometimes with brownish orange exudate; young twigs sparsely covered with appressed hairs, soon glabrous. Leaves: petiole 5-9 $\mathrm{mm}$ long, 4-5 mm diam.; lamina narrowly elliptic to elliptic, $29-42$ by $12-19 \mathrm{~cm}$ (leaf index 2.2-2.6), chartaceous, densely verruculose, pale greyish green and glabrous on both sides, base acute to obtuse, sometimes slightly asymmetrical, apex acuminate (acumen 5-10 mm long), secondary veins distinct, straight to slightly recurved, $18-20$ on either side of primary vein, slightly raised above, angles with primary vein $60-70^{\circ}$, arching to loop-forming under the apex only, smallest distance between loops and margin 1-1.5 mm, tertiary veins indistinct, not percurrent. Inflorescences on older branches, complete flowering state not seen, only a detached part of a thyrsoid with 2 developed rhipidia and loose flowers available; rhipidia 1- or 2-flowered; upper bract at 1/3-1/2 from the base of pedicel, shallowly triangular-ovate, 1.5-2 $\mathrm{mm}$ long, outer side densely covered with appressed hairs, pedicels $15-25 \mathrm{~mm}$ long, 1.5-2 mm diam., fruiting pedicels $20-35 \mathrm{~mm}$ long, 3.5-4.5 mm diam., densely covered with appressed hairs, becoming glabrous; flower buds globose to depressed globose; sepals basally connate, shallowly ovate-triangular, $1.5-2$ by $3-4.5 \mathrm{~mm}$, outer side rather densely covered with appressed hairs; petals cream, outer ones broadly ovate to ovate, slightly concave, $6-8$ by $6 \mathrm{~mm}$, outer side sparsely covered with appressed hairs, inner ones broadly ovate, strongly concave, $5-6$ by $4-6 \mathrm{~mm}$, outer side glabrous except for hairy exposed part; stamens 1-1.5 mm long, connective shield glabrous; carpels c. 10, c. $2 \mathrm{~mm}$ long, densely covered with appressed hairs, ovules not yet studied. Monocarps 2-9, green, maturing pinkish in vivo, brownish in sicco, transversely broadly ellipsoid (globose in vivo, fide Folsom et al. 4364), 24-29 by $32-35 \mathrm{~mm}$, glabrous, apex rounded, not apiculate, surface strongly shrivelled when dry, wall $0.5-1 \mathrm{~mm}$ thick, stipes $6-14$ by 4-5 mm; fruiting receptacle transversely broadly ellipsoid, 9-13 mm diam., glabrous. Seed 1 , lateral, $25-27$ by $20-24$ by $15-16 \mathrm{~mm}$, brownish.

Distribution - Panama (Darién) and possibly Colombia (Antioquia).

Habitat \& Ecology - In cloud forest. At an elevation of c. 1200 m. Flowering: April; fruiting: April, July. 
Notes - Unonopsis macrocarpa is very distinct by the extremely large and (in dry condition) shrivelled monocarps, in combination with very large leaves. Fresh monocarps are reported to be soft and pulpy (Folsom et al. 4364).

Soejarto 3488 (COL, F) from Colombia, Antioquia, Mun. Anorí, Corregimiento Providencia, Tirana Cr., elevation 400-700 m, 24 October 1972, possibly belongs to this species, but it differs by somewhat narrower leaves (to $10 \mathrm{~cm}$ wide) which, moreover, are sparsely (instead of densely) verruculose. See also comments by Maas et al. (1988: 266).

\section{Unonopsis magnifolia R.E. Fr. - Map 13}

Unonopsis magnifolia R.E. Fr. (1937) 250, t. 4. - Uvaria magnifolia Ruiz \& Pav. ex R.E. Fr. (1937) 250, nom. nud. - Uvaria magnifolia Ruiz \& Pav. (1959) 419, t. 480. - Type: Ruiz s.n. [1800] (holo B; iso MA, photograph seen), Ecuador, Guayas, Guayaquil ('Peru, Huayaquil'), 1800.

Tree 7-20 m tall, 5-30 cm diam.; young twigs densely covered with erect, brown hairs, soon glabrous. Leaves: petiole 5-10 mm long, 3-8 mm diam.; lamina narrowly elliptic to narrowly obovate, $28-60$ by $10-20 \mathrm{~cm}$ (leaf index $2.5-3.9$ ), chartaceous, densely verruculose only below, greyish green to greyish brown above, green to brown below, glabrous above, except for some hairs along primary vein, sparsely covered with appressed hairs below, becoming glabrous, base cordate to obtuse, often stem-clasping and sometimes oblique, apex obtuse to shortly and bluntly acuminate (acumen 1-20 mm long), secondary veins distinct, curved, 15-35 on either side of primary vein, strongly impressed above, angles with primary vein $50-60^{\circ}$, loop-forming at right to obtuse angles, or even forming a marginal vein, smallest distance between loops and margin 3-4 mm, tertiary veins distinct, percurrent. Inflorescences among leaves or on older branches, sometimes terminal or seemingly terminal due to abortion of vegetative growth tip, compact to sublax, composed of (1-)2-5 rhipidia; peduncle-like base $0-4$ mm long; axial internodes < 1-5 mm long; rhipidia 2- or 3-flowered, to 12(-20) flowers in succession, sympodial rachis to $15(-30) \mathrm{mm}$ long, with internodes 1-2 mm long; upper bract at 1/5-1/2 from the base of the pedicel, broadly ovate-triangular, 1-1.5 $\mathrm{mm}$ long, outer side densely covered with appressed and erect brown hairs; pedicels 10-25 mm long, 1-2 mm diam., fruiting pedicels 3-4 mm diam., densely covered with appressed and erect brown hairs; flower buds depressed ovoid to subglobose; sepals initially largely connate, finally becoming connate up to half their length, shallowly ovate-triangular, 1-2 by 2-3 mm, outer side densely covered with appressed brown hairs; petals cream, white, to yellow in vivo, outer ones broadly ovate, flat, $6-9$ by $5-8$ $\mathrm{mm}$, outer side densely covered with appressed brown hairs, inner ones ovate to broadly ovate, strongly concave, 5-10 by 4-7 mm, outer side glabrous except for hairy exposed part; stamens c. $1 \mathrm{~mm}$ long, connective shield papillate; carpels 10-15, 1-1.5 mm long, densely covered with appressed brown hairs, ovules 3, lateral. Monocarps 3-15, green, maturing red in vivo, brown in sicco, ellipsoid to subglobose, $15-25$ by $10-25 \mathrm{~mm}$, rather densely covered with appressed and erect brown hairs, finally glabrous, apex rounded, wall $0.3-0.5 \mathrm{~mm}$ thick, stipes $5-7$ by $1-1.5 \mathrm{~mm}$; fruiting receptacle depressed ovoid to globose, $3-12$ by $3-9 \mathrm{~mm}$, densely covered with appressed and erect brown hairs. Seeds 1 or 2, lateral, $14-15$ by $11-12$ by $6-8 \mathrm{~mm}$, brown.

Distribution - Ecuador (Esmeraldas, Guayas, Los Ríos, Napo, Sucumbios). 
Habitat \& Ecology - In non-inundated forest. At elevations up to $300 \mathrm{~m}$. Flowering: April to November; fruiting: February to November.

Vernacular names - Ecuador: Cacao de montaña, Cargadero.

Note - Unonopsis magnifolia is unique within the genus by a combination of very large and broad leaves with an obtuse to cordate, often stem-clasping base and an obtuse to shortly and bluntly acuminate apex.

\section{Unonopsis megalophylla Maas \& Westra, spec. nov. - Fig. 23; Map 14}

Species rami- vel cauliflora foliis permagnis distincta. - Typus: Shepherd 802 (holo WIS; iso HUA, MO), Colombia, Antioquia, near Planta Providencia, $26 \mathrm{~km} \mathrm{~S}$ and $23 \mathrm{~km} \mathrm{~W}$ (by air) of Zaragoza, in valley of Río Anorí, between Dos Bocas and Anorí, 400-700 m, 31 July 1977.

Tree 6-7 m tall, 7-12 cm diam.; young twigs rather densely to sparsely covered with appressed and sometimes also erect hairs, soon glabrous. Leaves: petiole 10-12 mm long, 4-5 mm diam.; lamina narrowly elliptic to narrowly obovate, $32-47$ by $8-14 \mathrm{~cm}$ (leaf index 2.5-4), chartaceous, not or sometimes slightly verruculose, dull above, pale greyish green to brown above, pale brown to brown below, glabrous above, glabrous below, except for a few appressed hairs along primary vein, base obtuse, sometimes acute, apex acuminate (acumen 10-20 mm long), sometimes acute, secondary veins distinct, curved, 14-21 on either side of primary vein, impressed above, angles with primary vein $50-60^{\circ}$, loop-forming at obtuse to right angles, smallest distance between loops and margin 1-3 mm, tertiary veins distinct, percurrent. Inflorescences on older branchlets or produced from the trunk, compact (to sublax), composed of (1 or) 2 rhipidia, peduncle-like base (0-) $2-5 \mathrm{~mm}$ long, axial internodes $\leq 1-1.5 \mathrm{~mm}$; rhipidia only seen with 1 fruit, to c. 15 flowers in succession, sympodial rachis to 20 mm long; upper bract at 1/5-1/4 from the base of the pedicel, broadly ovate-triangular, c. $2 \mathrm{~mm}$ long, outer side densely covered with appressed brown hairs; pedicels c. 25 $\mathrm{mm}$ long, 1-2 mm diam., fruiting pedicels 35-50 mm long, 1-3 mm diam., densely to finally sparsely covered with appressed brown hairs; flower buds not seen; sepals connate for half their length, shallowly ovate-triangular, $2-2.5$ by $4 \mathrm{~mm}$, outer side rather densely covered with appressed, brown hairs; petals greenish cream in vivo, outer ones broadly ovate, slightly concave, $7-8$ by $6-7 \mathrm{~mm}$, outer side densely covered with appressed grey hairs, inner ones ovate, strongly concave, c. 6 by 4-5 mm, outer side glabrous except for hairy exposed part; stamens c. $2 \mathrm{~mm}$ long, connective shield glabrous; carpels c. 50, 1.5-2 mm long, densely covered with appressed white hairs, ovules not yet studied. Monocarps (1-)5-20, green in vivo, black to brown in sicco, globose, depressed globose, to ellipsoid, 15-20 by $15 \mathrm{~mm}$, sparsely covered with appressed hairs, apex rounded, not apiculate, wall $0.2-0.5 \mathrm{~mm}$ thick, stipes $5-12$ by $1 \mathrm{~mm}$; fruiting receptacle subglobose to depressed ovoid, $4-5$ by $5-7 \mathrm{~mm}$, densely to sparsely covered with appressed hairs. Seed 1, lateral, c. 17 by 15 by $4 \mathrm{~mm}$ (somewhat damaged), dark brown.

Distribution - Colombia (Antioquia, Bolívar, Riseralda).

Habitat \& Ecology - In non-inundated forest, with among others Dioicodendron (Rubiaceae), Fabaceae, and Ficus spec. At elevations of 400-1150 m. Flowering: May, July; fruiting: March, April. 


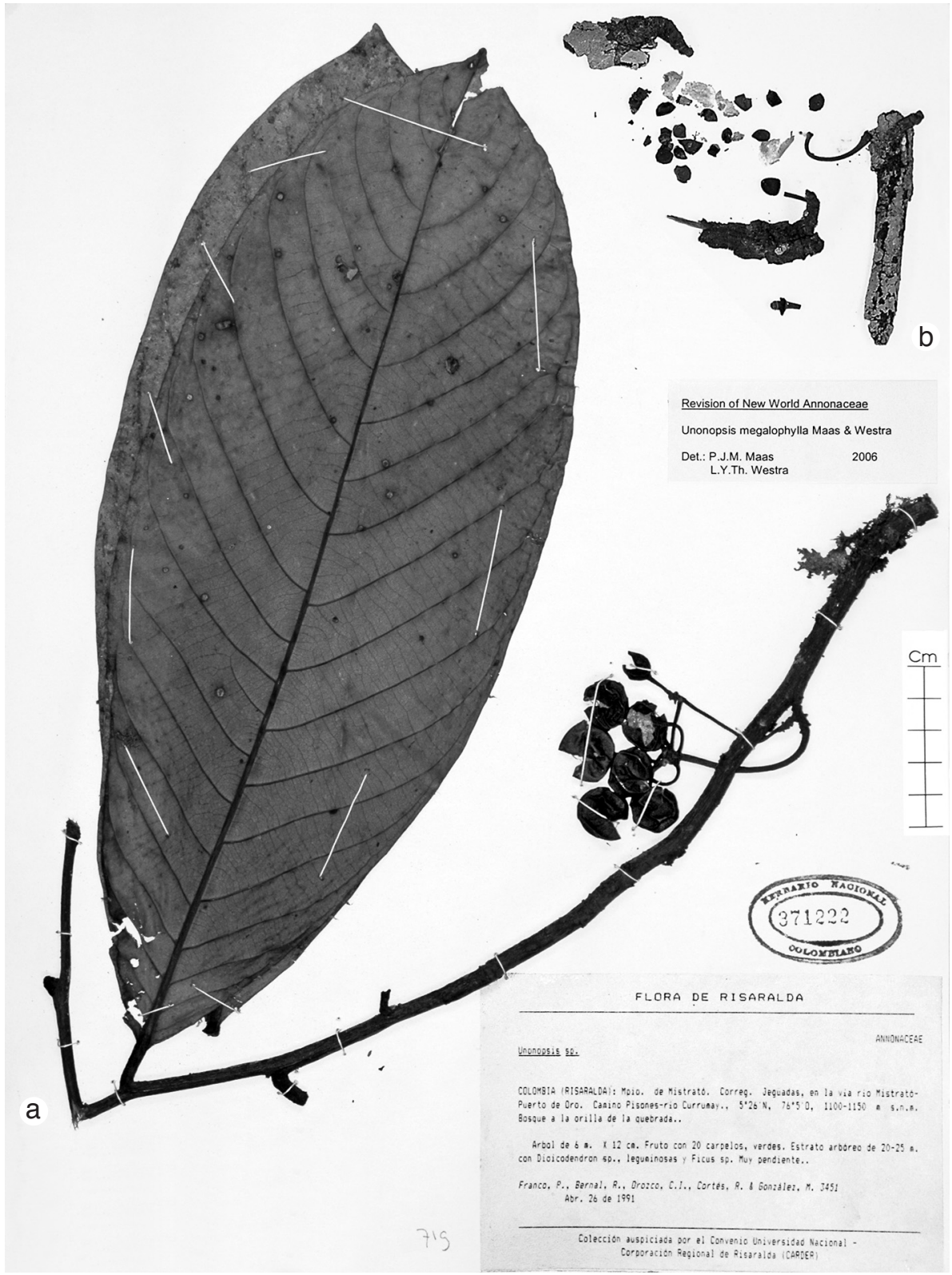

Fig. 23. Unonopsis megalophylla Maas \& Westra. a. Fruiting twig; b. fragment of flowering twig (a: Franco et al. 3451, COL; b: Shepherd 802, holo WIS).

Vernacular name - Colombia: Garrapata.

Note - Unonopsis megalophylla can be recognized by its very large leaves in combination with flowers and fruits produced from the older branches or from the trunk. 
Other specimens examined:

Colombia. Antioquia: near Planta Providencia, 28 km SW of Zaragoza, valley of Río Anorí in areas surrounding the confluence of Quebrada La Tirana and Río Anorí, c. 3 km upriver from Planta Providencia, 400-700 m, Alverson et al. 315 (WIS). Bolívar: La Raya, Quebrada La Culebra, Caño Caribón, between junction of Río Canca and Río Magadalena, 80-110 m, Gentry \& Cuadros 57399 (MO, U). Riseralda: Mun. Mistrató, Corregimiento Jeguadas, road Río Mistrato to Puerto de Oro, road from Pisones to Río Currumay, 1100-1150 m, Franco et al. 3451 (COL).

\section{Unonopsis megalosperma Maas \& Westra, spec. nov. - Fig. 24; Map 14}

Species foliis parvis ellipticis, monocarpiis seminibusque magnis conspicua. - Typus: Maas et al. 2789 (holo U, 2 sheets), Panama, Coclé, near saw mill, 8 km N of El Copé, 28 km NW of Penonomé, 600-750 m, 1 September 1977.

Tree 4-8 m tall; young twigs sparsely covered with appressed hairs, soon glabrous. Leaves: petiole 4-6 $\mathrm{mm}$ long, $2 \mathrm{~mm}$ diam.; lamina elliptic, symmetrical to slightly asymmetrical, $10-15$ by $4-6 \mathrm{~cm}$ (leaf index 2.2-2.5), chartaceous, sparsely or not verruculose, dull above, greyish green to brownish green above, greyish green below, sparsely covered with appressed, long hairs to glabrous above, sparsely covered with appressed long hairs below, particularly along primary vein to glabrous below, base obtuse, sometimes acute, apex acuminate (acumen 5-15 mm long), secondary veins distinct, curved, 7-9 on either side of primary vein, slightly raised to impressed above, angles with primary vein $35-50^{\circ}$, loop-forming at right angles, smallest distance between loops and margin 1-2 mm, tertiary veins distinct, percurrent. Inflorescences (only seen in McPherson 7665) on older branchlets, compact, composed of 1-3? rhipidia; rhipidia 1- (or 2-?)flowered; upper bract at the very base of the pedicel, broadly ovate-triangular, c. $1.5 \mathrm{~mm}$ long, outer side rather densely covered with appressed hairs; pedicels 10-15 mm long, $1 \mathrm{~mm}$ diam., fruiting pedicels not seen, rather densely

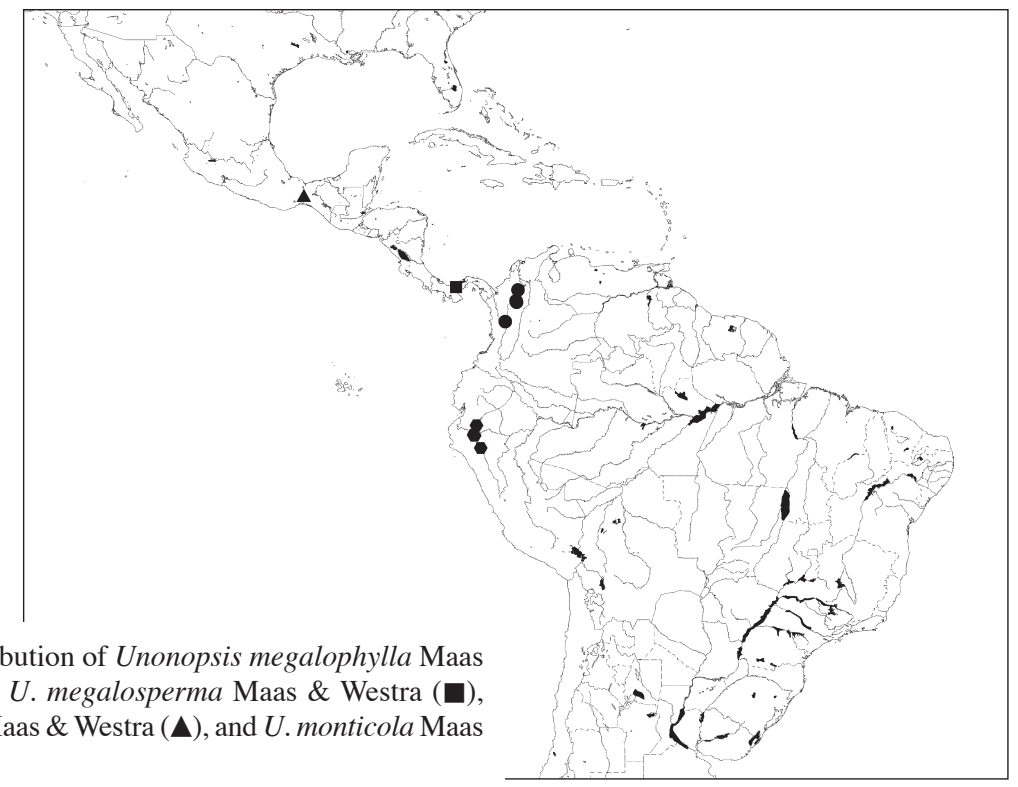

Map 14. Distribution of Unonopsis megalophylla Maas \& Westra (○), U. megalosperma Maas \& Westra (ם), $U$. mexicana Maas \& Westra ( $\mathbf{\Delta})$, and $U$. monticola Maas \& Westra ( ) 


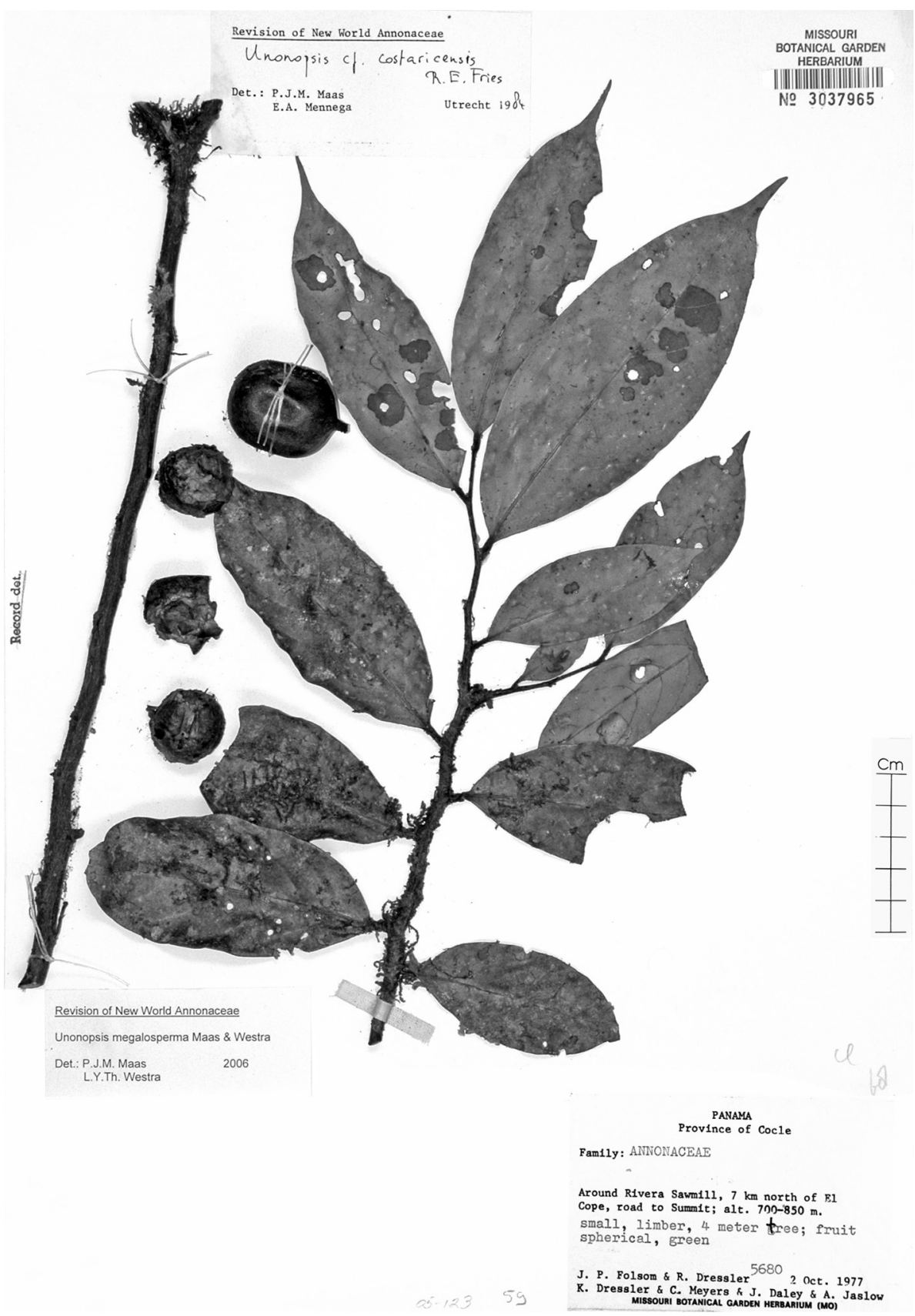

Fig. 24. Unonopsis megalosperma Maas \& Westra. Fruiting twig, loose monocarps (Folsom et al. $5680, \mathrm{MO})$. 
covered with appressed hairs; flower buds depressed ovoid; sepals basally connate, shallowly ovate-triangular, $1-1.5$ by $1.5-2 \mathrm{~mm}$, outer side rather densely covered with appressed hairs; petals white or green with yellow inner side in vivo, outer ones broadly ovate, slightly concave, $4-5\{-7\}$ by $4-5\{-8\} \mathrm{mm}$, outer side rather densely covered with appressed hairs, inner ones broadly ovate, strongly concave, $3-4\{-6\}$ by $3-4\{-5\} \mathrm{mm}$, outer side glabrous except for hairy exposed part; stamens c. 1.5 $\mathrm{mm}$ long, connective shield glabrous; carpels 5-10, c. $1.5 \mathrm{~mm}$ long, densely covered with appressed, white hairs, ovules 3, lateral. Monocarps 2, green in vivo, brown in sicco, very broadly ellipsoid, c. 33 by $30 \mathrm{~mm}$, rather densely covered with appressed hairs to finally glabrous, surface rugulose, apex rounded, not apiculate, wall $0.3-0.5$ $\mathrm{mm}$ thick, stipes c. 5 by $3 \mathrm{~mm}$; fruiting receptacle only seen when very young, rather densely covered with appressed hairs. Seeds 2 or 3, lateral, $20-24$ by $20-22$ by $10-12$ mm, dark brown.

Distribution - Panama (Coclé).

Habitat \& Ecology - In cloud forest. At elevations of 600-850 m. Flowering: September, November; fruiting: October.

Note - Unonopsis megalosperma, only known from the El Copé region in Coclé, Panama, is recognized by very large seeds and monocarps in combination with small, elliptic leaves.

Other specimens examined:

PANAMA. Coclé: around Rivera saw mill, $7 \mathrm{~km} \mathrm{~N}$ of El Copé, road to summit, 700-850 m, Folsom et al. 5680 (MO); above El Copé, 700-750 m, McPherson 7665 (U).

\section{Unonopsis mexicana Maas \& Westra, spec. nov. - Fig. 25; Map 14}

Species foliis pro ratione parvis et leviter asymmetricis, monocarpiis pluriseminalibus pariete crassa distincta. - Typus: Wendt et al. 5684 (holo U; iso CHAPA n.v.), Mexico, Oaxaca, Mun. Santa Maria de Chimalapa, Cerro de la Fortuna, $15 \mathrm{~km}$ NE of Santa Maria, 1000 m, 28 April 1987.

Tree 8-10 m tall; young twigs rather densely covered with appressed hairs, soon glabrous. Leaves: petiole 3-8 mm long, 1-2 mm diam.; lamina narrowly elliptic, symmetrical or slightly asymmetrical, $10-15$ by $3-4 \mathrm{~cm}$ (leaf index $3.3-3.8$ ), chartaceous, not verruculose, dull above, pale green above, pale brown to pale greenish brown below, glabrous above, sparsely covered with appressed hairs, mainly along primary and secondary veins below, soon glabrous, base acute, apex bluntly acuminate (acumen 5-10 mm long), secondary veins distinct, curved, 9-11 on either side of primary vein, flat to slightly raised above, angles with primary vein $35-50^{\circ}$, loop-forming at almost right angles, smallest distance between loops and margin 1-2 mm, tertiary veins indistinct, reticulate to slightly percurrent. Inflorescences on older branchlets, compact, composed of 2 or 3 rhipidia; peduncle-like base $0-2 \mathrm{~mm}$ long; rhipidia 1 - or 2 -flowered, to c. 5 flowers in succession; upper bract at 1/10-1/3 from the base of the pedicel, very broadly ovate, $1-1.5 \mathrm{~mm}$ long, outer side densely covered with appressed hairs; pedicels 15-30 mm long, c. $1 \mathrm{~mm}$ diam., densely covered with appressed hairs, soon sparsely so; flower buds globose to broadly ovoid; sepals basally connate, deltate to shallowly triangular, $1.5-2$ by $1.5-3 \mathrm{~mm}$, outer side rather densely covered with appressed hairs; petals cream in vivo, outer ones broadly ovate, slightly concave, 7-8 


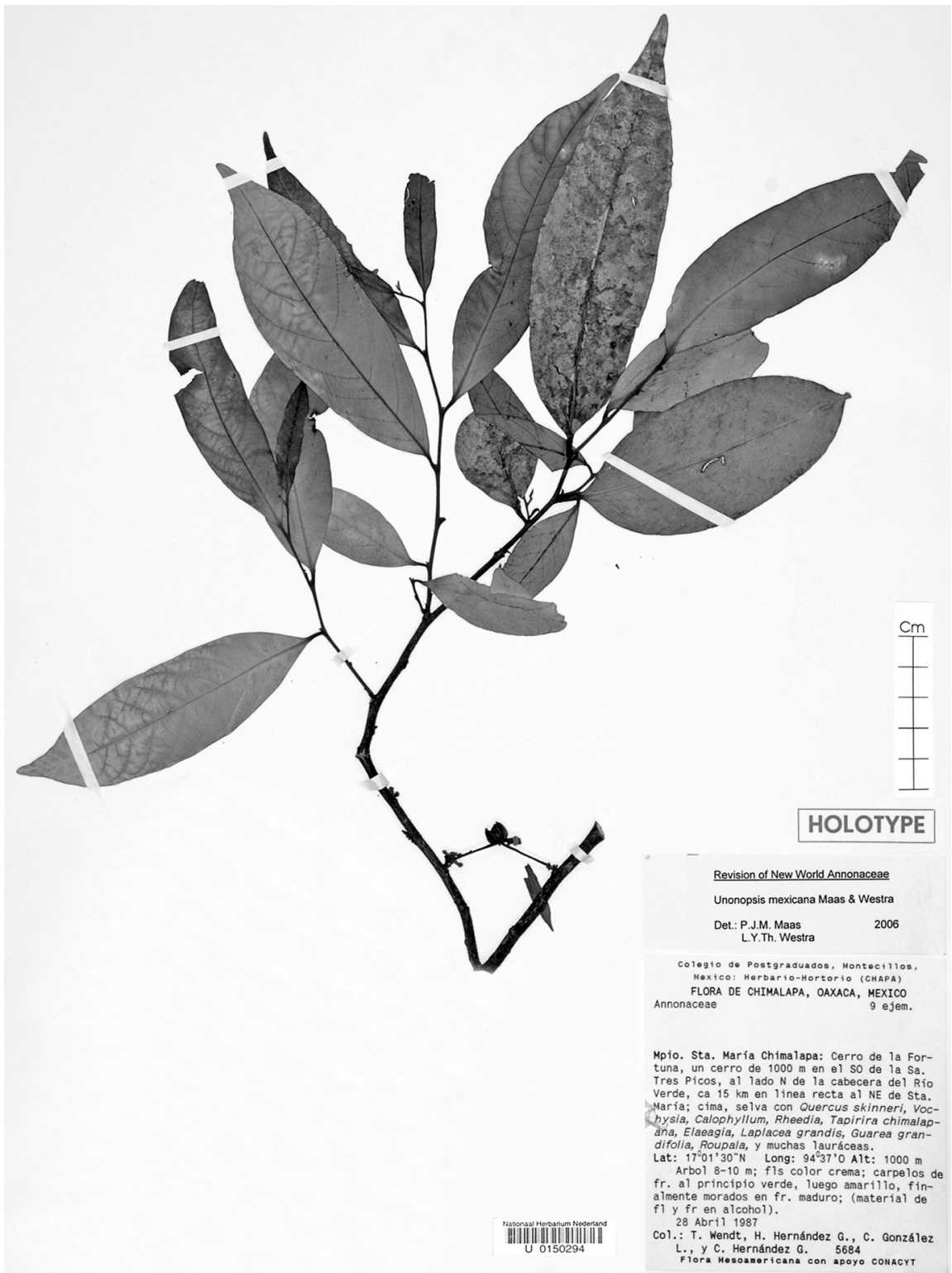

Fig. 25. Unonopsis mexicana Maas \& Westra. Flowering twig (Wendt et al. 5684, holo U).

by $6-7 \mathrm{~mm}$, outer side rather densely to sparsely covered with appressed hairs, inner ones broadly ovate, strongly concave, $5-7$ by $5-6 \mathrm{~mm}$, outer side glabrous except for hairy exposed part; stamens 1.5-2 mm long, connective shield glabrous; carpels 12-15, 2-3 mm long, densely covered with appressed, white hairs, ovules 4 or 5 , lateral. Monocarps: number unknown (only a single monocarp seen), green, maturing 
yellow to finally dark purple ('morado'), ellipsoid, slightly asymmetric, c. $\{35$ by 23 $\mathrm{mm}$, glabrous, apex rounded, bluntly apiculate (apiculum c. 1 by $3 \mathrm{~mm}$ ), wall $\{1.5-3$ $\mathrm{mm}$ thick\}, stipes c. 10 by $4 \mathrm{~mm}$; fruiting receptacle not seen. Seeds 3, lateral, c. 15 by 12 by $7-8 \mathrm{~mm}$, dark brown.

Distribution - Mexico (Oaxaca).

Habitat \& Ecology - In non-inundated forest, with Quercus skinneri, Vochysia, Calophyllum, Rheedia, Tapirira chimalapana, Elaeagia, Laplacea grandis, Guarea grandifolia, Roupala, and many Lauraceae. At an elevation of c. 1000 m. Flowering and fruiting: April. Only known from the type collection.

Notes - Unonopsis mexicana is the only representative of the genus in Mexico.

It is characterized by tiny leaves in combination with a few-flowered inflorescence, and a very large, slightly asymmetrical, thick-walled, several-seeded monocarp.

\section{Unonopsis monticola Maas \& Westra, spec. nov. - Fig. 26; Map 14}

Species inflorescentiis plerumque multifloris, venis secundariis sub angulo $30-50^{\circ}$ e costa exeuntibus et pro majore parte eucamptodromis notabilis. - Typus: J. Campos \& Vargas 3910 (holo U; iso MO), Peru, Cajamarca, Prov. San Ignacio, San José de Lourdes, Laurel, 1500-1600 m, 17 May 1997.

Tree 6-25 m tall; young twigs densely covered with erect and appressed hairs, soon glabrous. Leaves: petiole 5-8 $\mathrm{mm}$ long, $1.5-3 \mathrm{~mm}$ diam.; lamina generally narrowly elliptic to narrowly obovate, $13-21(-30)$ by $4.5-9 \mathrm{~cm}$ (leaf index $2.1-3.7$ ), chartaceous, not or sparsely verruculose, greyish green to greyish brown above, brown, rarely grey below, sparsely covered with appressed and erect hairs above, particularly along primary vein, sparsely covered with mainly appressed hairs below, particularly along primary and secondary veins, base acute, apex shortly acuminate (acumen $2-10(-20)$ mm long), secondary veins distinct, curved, 7-11 on either side of primary vein, impressed above, angles with primary vein $30-50^{\circ}$, eucamptodromous, or loop-forming (brochidodromous) near the apex only, smallest distance between secondary veins and margin 1-2 mm, tertiary veins indistinct, percurrent. Inflorescences among leaves, rarely terminal, or (at least in fruit) on older branches, compact to sublax, composed of 1-5 rhipidia (in fruiting stage a single fruit remaining); peduncle-like base $0-3 \mathrm{~mm}$ long; axial internodes $<1-2 \mathrm{~mm}$ long; rhipidia 1-3-flowered, to 5 flowers in succession, sympodial rachis to $4 \mathrm{~mm}$ long; upper bract at 1/8-1/4 from the base of the pedicel, shallowly ovate-triangular, 1-1.5 mm long, outer side densely covered with appressed brown hairs; pedicels $7-15 \mathrm{~mm}$ long, $1-1.5 \mathrm{~mm}$ diam., fruiting pedicels to $20 \mathrm{~mm}$ long, to $3 \mathrm{~mm}$ diam., densely covered with appressed, brown hairs; flower buds broadly ovoid; sepals basally connate, shallowly ovate-triangular, $1-1.5$ by $2-3 \mathrm{~mm}$, outer side densely covered with appressed, brown hairs; petals cream to creamy white in vivo, outer ones broadly ovate, flat, $5-6$ by $5-6 \mathrm{~mm}$, outer side densely covered with appressed, brownish white hairs, inner ones broadly ovate-triangular, concave, $3-5$ by $3-4 \mathrm{~mm}$, outer side glabrous, but keel densely covered with appressed brownish white hairs; stamens c. $1.5 \mathrm{~mm}$ long, connective shield glabrous; carpels 25-30, 1-1.5 mm long, densely covered with appressed hairs, ovule 1, basal. Monocarps 2-10, green in vivo, blackish in sicco, globose to ellipsoid, (12-) $15-25$ by $14-18 \mathrm{~mm}$, sparsely covered with appressed hairs to finally glabrous, apex rounded, asymmetrically apiculate 


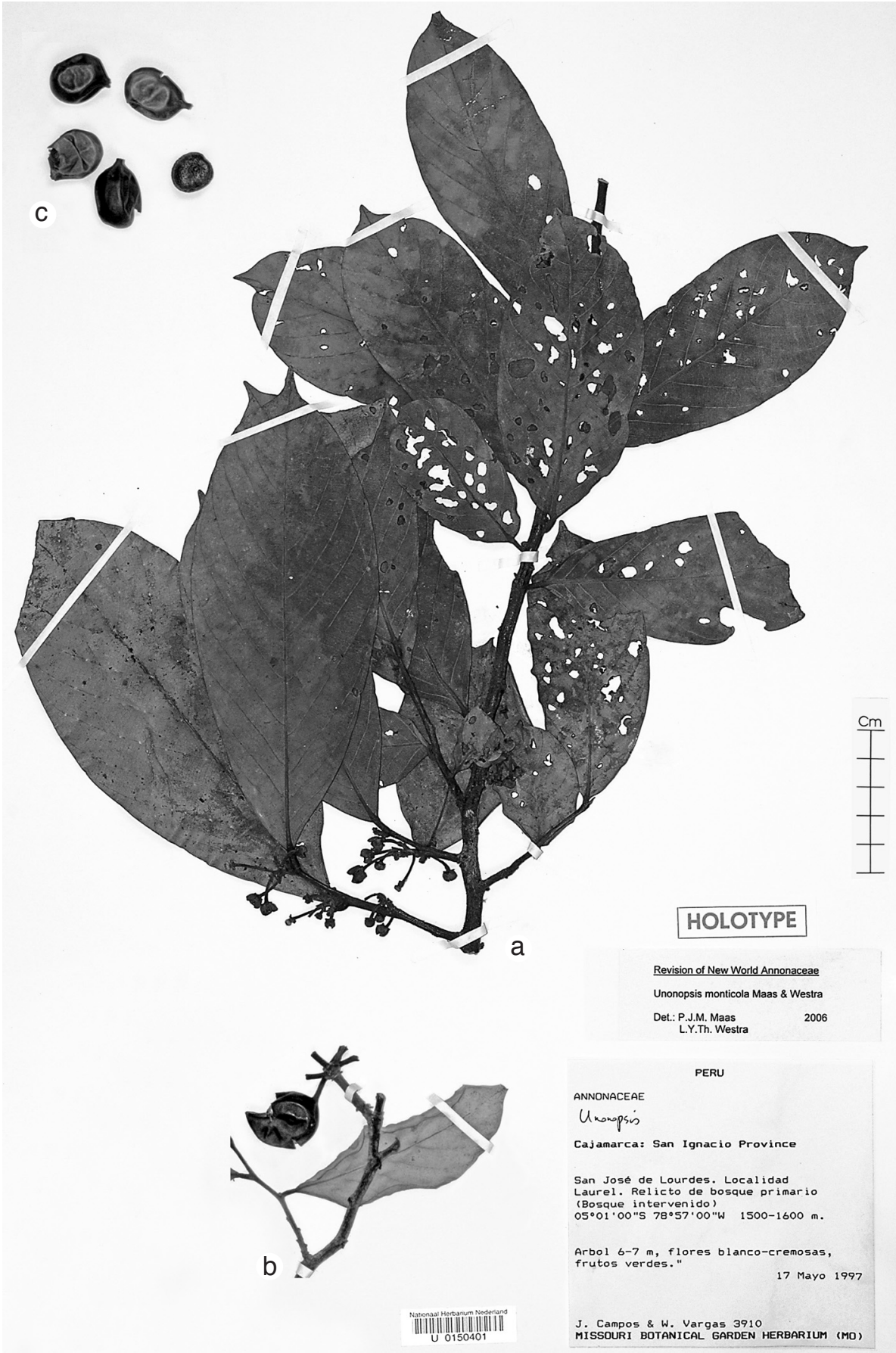

Fig. 26. Unonopsis monticola Maas \& Westra. a. Flowering twig; b. part of fruiting twig; c. loose monocarps (a: J. Campos \& Vargas 3910, holo U; b \& c: Vásquez \& J. Campos 26185, U). 
(apiculum $<0.1 \mathrm{~mm}$ long), wall $0.5-1 \mathrm{~mm}$ thick, stipes $7-15$ by $1.5-2 \mathrm{~mm}$; fruiting receptacle broadly ovoid, 5-7 $\mathrm{mm}$ diam., densely covered with erect and appressed hairs. Seed 1 , basal, $14-15$ by $11-12$ by $6-11 \mathrm{~mm}$, dark, shiny brown.

Distribution - Ecuador (Zamora-Chinchipe), Peru (Amazonas, Cajamarca).

Habitat \& Ecology - In non-inundated, primary, andean forest, on yellowish soil. At elevations of 1400-2050 m. Flowering: April, May, June, September, November; fruiting: March, June to September, November.

Notes - Unonopsis monticola is recognized by secondary veins which form a sharp angle with the primary vein and are not or hardly loop-forming over most of the lamina length. The inflorescences are mostly many-flowered, but often forms reduced to a single flower are also present.

Two vegetative twigs of J. Campos et al. 3630 have somewhat larger leaves (27-30 by $6-9 \mathrm{~cm}$ ) and a quite long acumen up to $20 \mathrm{~mm}$ long.

Selection of other specimens (7) examined:

ECUADOR. Zamora-Chinchipe: near mining camp at Río Tundaime, 1400-1500 m, Van der Werff et al. $19504(\mathrm{U})$.

PERU. Amazonas: Prov. Luya, Camporredondo, Jaipe, 2050 m, J. Campos et al. 3630 (U); Prov. Luya, Camporredondo, Tullanya, 1550 m, Díaz S. \& Peña 8700 (U). Cajamarca: Prov. San Ignacio, San José de Lourdes, Estrella del Oriente, 1630 m, J. Campos et al. 4324 (U); Prov. San Ignacio, Distr. Huarango, Nuevo Mundo, Gosén, 1500-1600 m, Rodríguez R. \& Reyes M. 1789 (U).

\section{Unonopsis onychopetaloides Maas \& Westra, spec. nov. - Fig. 27; Map 15}

Species monocarpiis paucis maximis ad $40 \mathrm{~mm}$ diametro breviter stipitatis bene distincta. - Typus: C. \& M. Aulestia 1011 (holo NY; iso F, MO, QCNE, U), Ecuador, Esmeraldas, San Lorenzo, Reserva Etnica Awá, Parroquia Ricaurte, Centro Pambilar, 500 m, 21 January 1993.

Tree 12-25 m tall, 30-40 cm diam., sometimes with red exudate; young twigs sparsely covered with appressed hairs, soon glabrous. Leaves: petiole 4-6 mm long, 1-2 mm diam.; lamina narrowly elliptic, sometimes narrowly obovate, asymmetrical, 14-21 by $3.5-7 \mathrm{~cm}$ (leaf index 3.3-4), chartaceous, sparsely verruculose, mainly along primary vein, greyish brown above, brown below, glabrous above, sparsely covered with appressed hairs below, mainly along primary and secondary veins, base acute, apex acuminate (acumen 5-10 mm long), secondary veins distinct, curved, 10-13 on either side of primary vein, slightly impressed to slightly raised above, angles with primary vein $55-60^{\circ}$, loop-forming at right to obtuse angles, smallest distance between loops and margin 1-2 mm, tertiary veins distinct, percurrent. Inflorescences among leaves or on older branches, compact, composed of 1 or 2 rhipidia; only 1 flower after anthesis phase seen, to 4 flowers in succession; sympodial rachis c. $4 \mathrm{~mm}$ long; upper bract at c. 1/2 from the base of the pedicel, broadly ovate-triangular, c. $1.5 \mathrm{~mm}$ long, outer side densely covered with appressed hairs; pedicels c. $25 \mathrm{~mm}$ long, $1 \mathrm{~mm}$ diam., fruiting pedicels to c. $30 \mathrm{~mm}$ long, to $3 \mathrm{~mm}$ diam., sparsely covered with appressed hairs; flower buds not seen; sepals basally connate, shallowly ovate-triangular, c. 1.5 by $1.5-2 \mathrm{~mm}$, outer side densely covered with appressed hairs; petals, stamens, and carpels not seen. Monocarps 1-5, green to greenish yellow in vivo, brownish black in sicco, globose, 25-40 mm diam., glabrous, apex rounded, not apiculate, wall 0.5-1 mm thick, stipes 4-10 by $1-3 \mathrm{~mm}$; fruiting receptacle subglobose, $5-7 \mathrm{~mm}$ diam., sparsely covered 


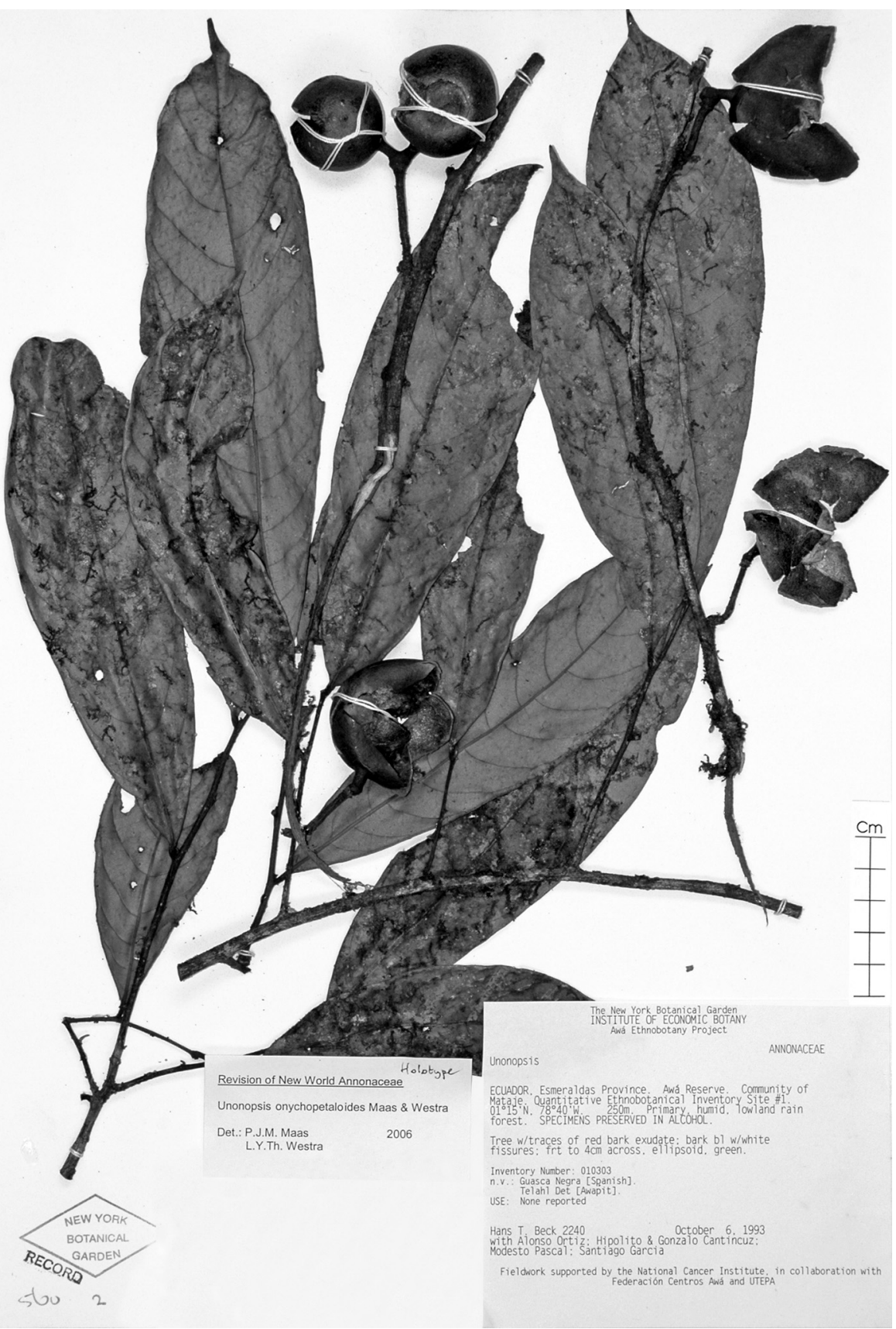

Fig. 27. Unonopsis onychopetaloides Maas \& Westra. Fruiting twig (H.T. Beck et al. 2240, NY). 


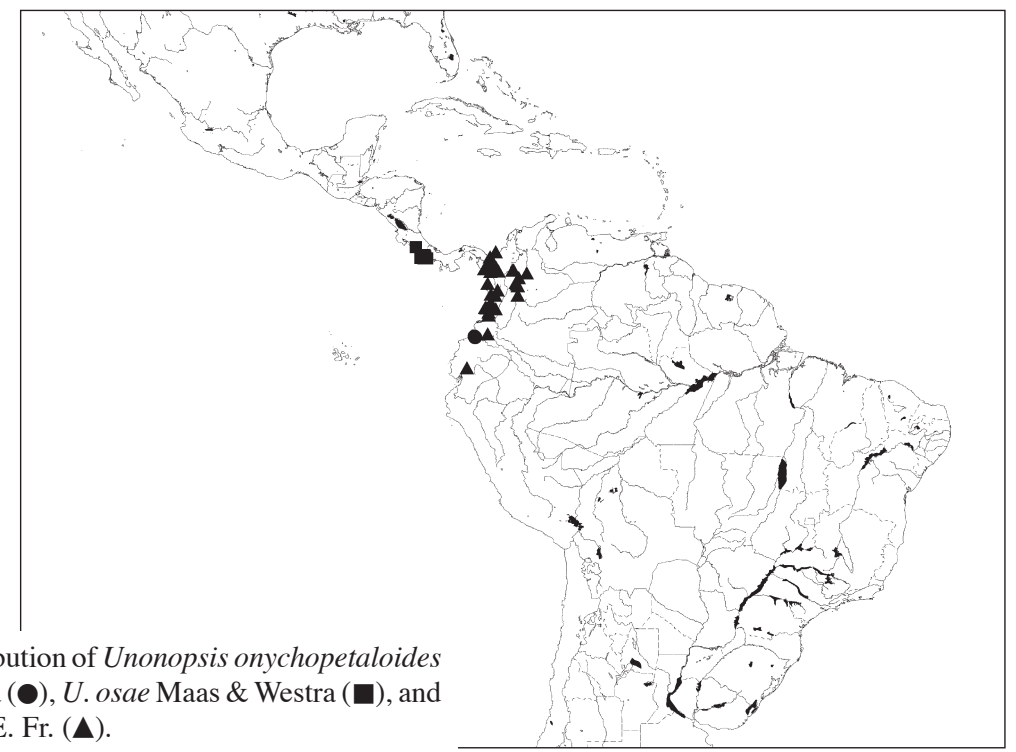

Map 15. Distribution of Unonopsis onychopetaloides Maas \& Westra (•), U. osae Maas \& Westra (ם), and U. pacifica R.E. Fr. (山).

with appressed hairs, soon glabrous. Seed 1, lateral, $20-30$ by $15-20$ by $12-15 \mathrm{~mm}$, 'completely surrounded with a dense, white, pulpy layer'.

Distribution - Ecuador (Esmeraldas, Sucumbios).

Habitat \& Ecology — In non-inundated forest. At elevations of 200-500 m. Flowering: unknown; fruiting: May, September, October, January.

Vernacular names - Ecuador: Cargadera negra, Guasca negra, Telahl det (Awapit).

Notes - Unonopsis onychopetaloides is recognized by its very large, 1-seeded monocarps (up to $40 \mathrm{~mm}$ in diam.!), provided with short stipes $4-10 \mathrm{~mm}$ long. The fruit strongly reminds of the genus Onychopetalum, hence the epithet.

This species has been referred to as Unonopsis spec. 4 by Chatrou et al. (1997: 120), and as Onychopetalum by Schatz \& Jørgensen (1999: 214).

Other specimens examined:

ECUADOR. Esmeraldas: San Lorenzo Cantón, Parroquia Mataje, Reserva Etnica Awá, Centro Mataje, 200 m, C. Aulestia et al. 342, 556 (U); Awá Reserve, Community of Mataje, 250 m, H.T. Beck et al. 2240 (U). Sucumbios: Cantón Cascales, Parroquia El Dorado, between La Troncal and Los Angeles, 250 m, E. Freire et al. 2196 (MO).

\section{Unonopsis osae Maas \& Westra, spec. nov. - Fig. 28; Map 15}

Unonopsi panamensi proxima sed rami- vel cauliflora, praeterea foliis leviter falcatis, glabris, verruculosis, pedicellis gracilibus $25-40 \mathrm{~mm}$ longis, monocarpiis paucioribus differt. - Typus: Allen 5839 (holo F, 2 sheets; iso GH, US), Costa Rica, Puntarenas, Esquinas forest, between Río Esquinas and Palmar Sur de Osa, 75 m, 5 February 1951.

Cauliflorous or ramiflorous tree or shrub 3-10 m tall, 3-15 cm diam.; young twigs glabrous. Leaves: petiole 5-10 $\mathrm{mm}$ long, 1-3 mm diam.; lamina narrowly oblongelliptic, slightly falcate, $15-36$ by $3-9 \mathrm{~cm}$ (leaf index $4.2-6.2$ ), chartaceous, not or sparsely verruculose, mainly along primary vein, slightly shiny above, pale greyish green 


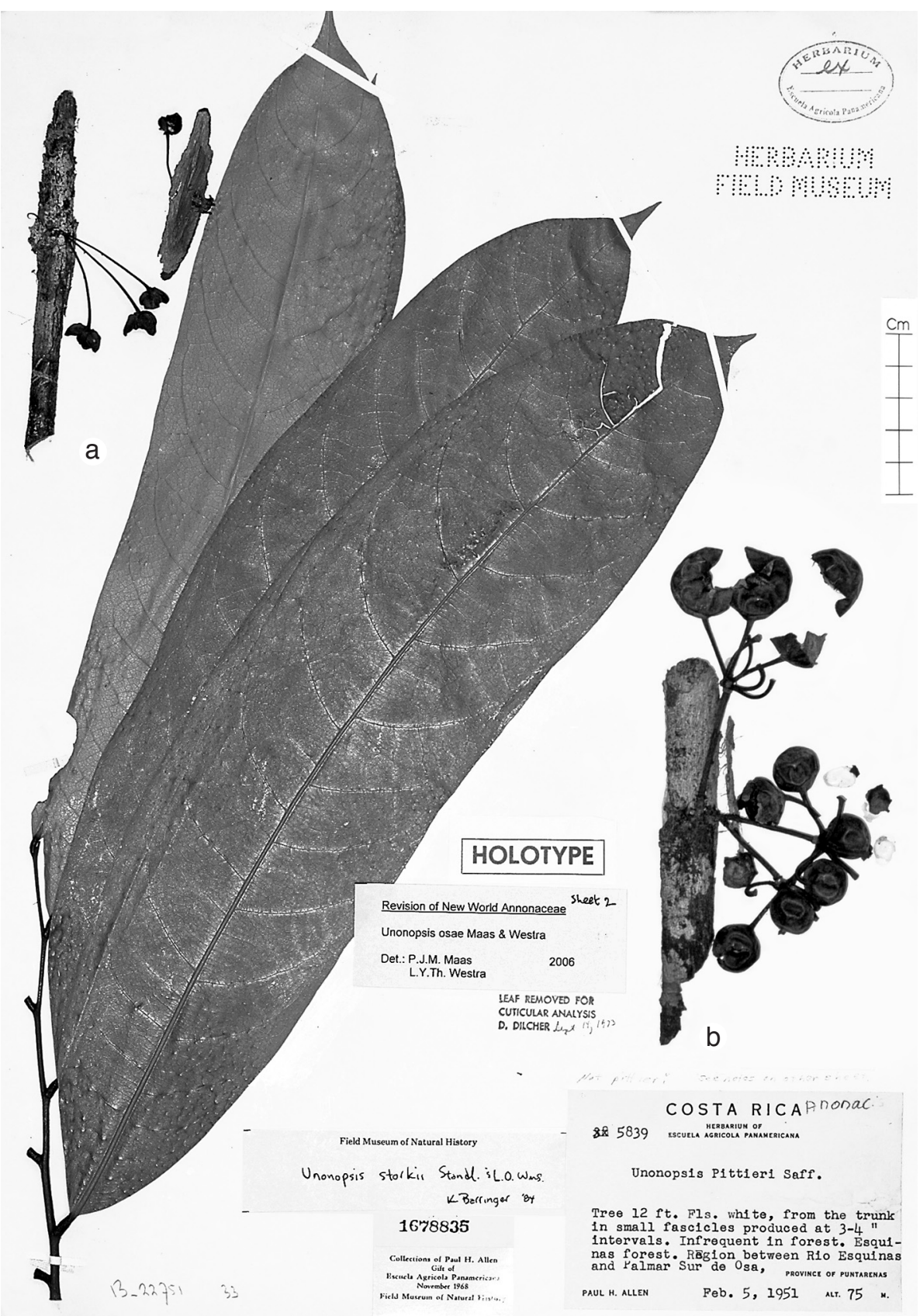

Fig. 28. Unonopsis osae Maas \& Westra. a: Leafy twig and part of flowering twig; b. part of fruiting twig (a: Allen 5839, holo part 2, F; b: Kernan \& Phillips 1042, CR). 
to brownish green above, pale greyish green to pale brown below, glabrous on both sides, base acute, apex acuminate (acumen 5-10 mm long), secondary veins distinct, curved, $12-15$ on either side of primary vein, raised above, angles with primary vein $55-70^{\circ}$, loop-forming at obtuse to right angles, smallest distance between loops and margin 3-6 mm, tertiary veins distinct, reticulate. Inflorescences on older branches or produced from the trunk, compact, composed of 1-3 (or possibly more) rhipidia (though mostly only 1 rhipidium remaining in material seen), sessile; rhipidia 1 - or 2-flowered, to c. 5 flowers in succession; sympodial rachis to $3 \mathrm{~mm}$ long; upper bract at 1/5-1/4 from the base of the pedicel, broadly to shallowly ovate-triangular, c. $1 \mathrm{~mm}$ long, outer side sparsely covered with appressed hairs; pedicels $25-40 \mathrm{~mm}$ long, 0.5-1 mm diam., fruiting pedicels $1-3 \mathrm{~mm}$ diam., sparsely covered with appressed hairs; flower buds depressed ovoid; sepals basally connate, shallowly ovate-triangular, $1-1.5$ by $1-3 \mathrm{~mm}$, outer side sparsely to rather densely covered with appressed hairs; petals white with green base in vivo, outer ones broadly ovate, concave, $6-8$ by $6-7$ $\mathrm{mm}$, outer side densely covered with appressed hairs, inner ones ovate to broadly so, concave, 5-7 by 4-7 mm, outer side glabrous, but keel densely covered with appressed hairs; stamens 1.5-2 mm long, connective shield glabrous; carpels 10-20, 2-3 mm long, densely covered with appressed hairs near the apex, basal part glabrous, ovules 2, lateral. Monocarps 5-20, glaucous, yellow, maturing orange to red, or deep purple in vivo, black in sicco, globose to ellipsoid, $10-22 \mathrm{~mm}$ diam., glabrous, apex rounded, wall $0.2-0.3\{-0.5\} \mathrm{mm}$ thick, stipes $10-20$ by $1 \mathrm{~mm}$; fruiting receptacle depressed ovoid, $1-2$ by $3-5 \mathrm{~mm}$, sparsely covered with appressed hairs. Seeds (1 or) 2, lateral, $11-13$ by $9-11$ by $3-6 \mathrm{~mm}$, brown.

Distribution - Costa Rica (Puntarenas: Osa Peninsula).

Habitat \& Ecology - In non-inundated forest. At elevations of 0-540 m. Flowering: February, May, October, November; fruiting: throughout the year.

Note - Unonopsis osae looks somewhat similar to U. panamensis, but it clearly differs from that species by essentially glabrous young twigs and leaves (a rare feature in the genus, cf. U. stevensii), slightly falcate leaves, and a much lower average number of monocarps (5-20 vs 10-50), while the monocarps are black rather than brown when dry. Cauliflory often occurs in U. osae, but has not been observed in U. panamensis.

Selection of other specimens (18) examined:

Costa Rica. Puntarenas: Cantón de Golfito, Puerto Jiménez, 100 m, Aguilar R. 368 (MO); E of Quepos, 350-450 m, Burger et al. 10618 (U); W of Rincón de Osa, 250-540 m, Croat \& Grayum 59852 (MO, U); Osa Peninsula, Rancho Quemado, c. $15 \mathrm{~km} \mathrm{~W}$ of Rincón, 250-350 m, Hammel et al. 16946 (F, INB, MO, U); Cantón de Osa, Aguabena, Quebrada Orito, 350 m, G. Herrera et al. 4486 (CR, F, MO); Parque Nacional Esquinas, La Gamba, W. Huber et al. 134 (WU); Refugio de Fauna Silvestre Golfito, 100 m, Jiménez M. 459 (MO); Parque Nacional Corcovado, La Ceibita, 100 m, Kernan \& Phillips 1042 (CR, INB, MO); Distr. Puerto Jiménez, Guadeloupe de La Palma, 100 m, Maas et al. 9499 (INB, NY, U); Río Naranjo, 200-250 m, Tonduz 7592 (BR).

\section{Unonopsis pacifica R.E. Fr. - Map 15}

Unonopsis pacifica R.E. Fr. (1950) 340, pl. 5. - Type: Cuatrecasas 15973 (holo S; iso F), Colombia, El Valle, Río Yurumanguí, Veneral, 28 January to 28 February 1944.

Tree 6-28 m tall, 10-35 cm diam., often with red exudate; trunk slightly longitudinally fissured; young twigs rather densely covered with erect hairs, soon glabrous. 
Leaves: petiole 5-10 $\mathrm{mm}$ long, 2-3 $\mathrm{mm}$ diam.; lamina narrowly ovate to narrowly obovate, $18-40$ by $7-14 \mathrm{~cm}$ (leaf index $2.8-4$ ), chartaceous, rather densely to densely verruculose, pale greyish green to pale brown on both sides, glabrous above or with some hairs along primary and secondary veins, soon glabrous, sparsely covered with appressed hairs to glabrous below, base obtuse to slightly cordate, apex acute to abruptly acuminate (acumen 1-10 mm long), secondary veins distinct, curved, 15-18 on either side of primary vein, impressed above, angles with primary vein $45-50^{\circ}$, loop-forming at obtuse angles, smallest distance between loops and margin $2-3 \mathrm{~mm}$, tertiary veins indistinct, percurrent. Inflorescences on older branches, rarely (in young stage) among leaves, (sub) lax or less often compact, composed of 2-7 rhipida; peduncle-like base 0-3(-10) mm long; axial internodes 1-3 mm long; rhipidia 2- or 3-flowered, to 10 flowers in succession; sympodial rachis $10-35 \mathrm{~mm}$ long, with internodes 2-6 mm long; upper bract at 1/4-1/2 from the base of the pedicel, ovate-triangular to broadly so, 1-2 mm long, outer side densely covered with appressed and erect hairs, soon glabrous; pedicels $10-25 \mathrm{~mm}$ long, c. $1 \mathrm{~mm}$ diam., fruiting pedicels $20-45 \mathrm{~mm}$ long, 2-4 mm diam., subglabrous; flower buds subglobose; sepals almost completely connate into a cup-shaped, hardly lobed structure 4-6 mm diam., 1-2 mm long, often becoming somewhat reflexed, outer side densely covered with appressed hairs; petals yellow to white in vivo, outer ones ovate-triangular to broadly so, slightly concave, $7-10$ by $6-7 \mathrm{~mm}$, outer side densely covered with appressed hairs, inner ones ovate, strongly concave, $5-6$ by $4-5 \mathrm{~mm}$, outer side glabrous except for hairy exposed part; stamens 1-1.5 mm long, connective shield glabrous; carpels 10-15, 3.5-4 mm long, subglabrous, ovule 1, basal. Monocarps 5-12, green to yellow, maturing red to shiny black in vivo, brown to sometimes blackish in sicco, globose, 12-22 mm diam., glabrous, apex rounded, wall $0.2-0.3\{-1\} \mathrm{mm}$ thick, stipes $8-15$ by $1-2 \mathrm{~mm}$; fruiting receptacle depressed ovoid to globose, 3-6 by 5-10 mm, glabrous. Seed 1, lateral, $15-18$ by $12-14$ by $8-9 \mathrm{~mm}$, brown.

Distribution - Panama (Darién), Colombia (Antioquia, Cauca, Chocó, El Valle, Nariño, Santander), Ecuador (Los Ríos).

Habitat \& Ecology - In non-inundated forest. At elevations of 0-250(-850) m. Flowering: May, June, September, November, January, February; fruiting: September to June.

Vernacular names - Colombia: Cargadero, Yaya.

Notes - Unonopsis pacifica is probably closest to the Ecuadorian endemic U. magnifolia, but the latter is distinct by the often stem-clasping leaf base and by the longer stipes.

Callejas et al. 4580 (HUA, MO, NY, U) from Colombia (Antioquia: Mun. Anorí) is aberrant in having more acute petals than in normal $U$. pacifica. As leaves and inflorescence characters match well with $U$. pacifica, we provisionally included this collection here.

\section{Unonopsis panamensis R.E. Fr. - Map 16}

Unonopsis panamensis R.E. Fr (1955) 151. - Type: Allen 2647 (holo MO; fragment S), Panama, Panama, Cerro Campana, trail from Campana to Chica, 600-800 m, 10 August 1941.

Tree or shrub 4-10 m tall; young twigs sparsely covered with erect, white, minute hairs and sometimes with a few appressed hairs, soon glabrous. Leaves: petiole 5-10 mm 
long, $2-3 \mathrm{~mm}$ diam.; lamina narrowly oblong-elliptic, (15-)24-40 by $4-8(-10)$ $\mathrm{cm}$ (leaf index 3.7-5.2), chartaceous, densely verruculose, dull above, greyish green above, greyish green to pale brown below, glabrous above, sparsely covered with some scattered appressed hairs to glabrous below, base acute to obtuse, apex acuminate (acumen 5-20 mm long), secondary veins distinct, curved, 14-17(-21) on either side of primary vein, strongly raised above, angles with primary vein $50-60^{\circ}$, loop-forming at right to obtuse angles, smallest distance between loops and margin $1-3 \mathrm{~mm}$, tertiary veins distinct, percurrent. Inflorescences on older branches, usually developing a single flower/fruit, rarely 2 flowers; upper bract at c. $1 / 4$ from the base of the pedicel, broadly ovate-triangular, c. $1 \mathrm{~mm}$ long, outer side densely covered with appressed brown hairs; pedicels c. $10 \mathrm{~mm}$ long, $1 \mathrm{~mm}$ diam., fruiting pedicels $10-20 \mathrm{~mm}$ long, 2-4 mm diam., densely covered with appressed, brown hairs, soon glabrous or almost so; flower buds subglobose; sepals basally connate, shallowly triangular, $1.5-2$ by $2-2.5 \mathrm{~mm}$, outer side densely covered with appressed hairs; petals white in vivo, outer ones broadly to depressed ovate, slightly concave, $6-9$ by $6-12 \mathrm{~mm}$, outer side rather densely covered with appressed hairs, inner ones broadly ovate, strongly concave, $4-7$ by $4-6 \mathrm{~mm}$, outer side glabrous except for hairy exposed part; stamens $1-1.5 \mathrm{~mm}$ long, connective shield glabrous; carpels 50-75, 1-1.5 mm long, densely covered with appressed hairs, ovules 3 or 4 , lateral. Monocarps $10-50$, green, maturing yellowish orange to red in vivo, almost always brown in sicco, globose to ellipsoid, $10-20$ by $10-15 \mathrm{~mm}$, glabrous, apex rounded, rarely apiculate (apiculum $<0.1 \mathrm{~mm}$ long), wall $0.2-0.5 \mathrm{~mm}$ thick, stipes $10-20$ by $1-1.5 \mathrm{~mm}$; fruiting receptacle depressed ovoid, $6-7$ by $8-12$ $\mathrm{mm}$, sparsely covered with appressed and erect hairs. Seeds 1 or 2 , lateral, 10-12 by $9-10$ by $5-7 \mathrm{~mm}$, dark brown.

Distribution - Throughout Panama.

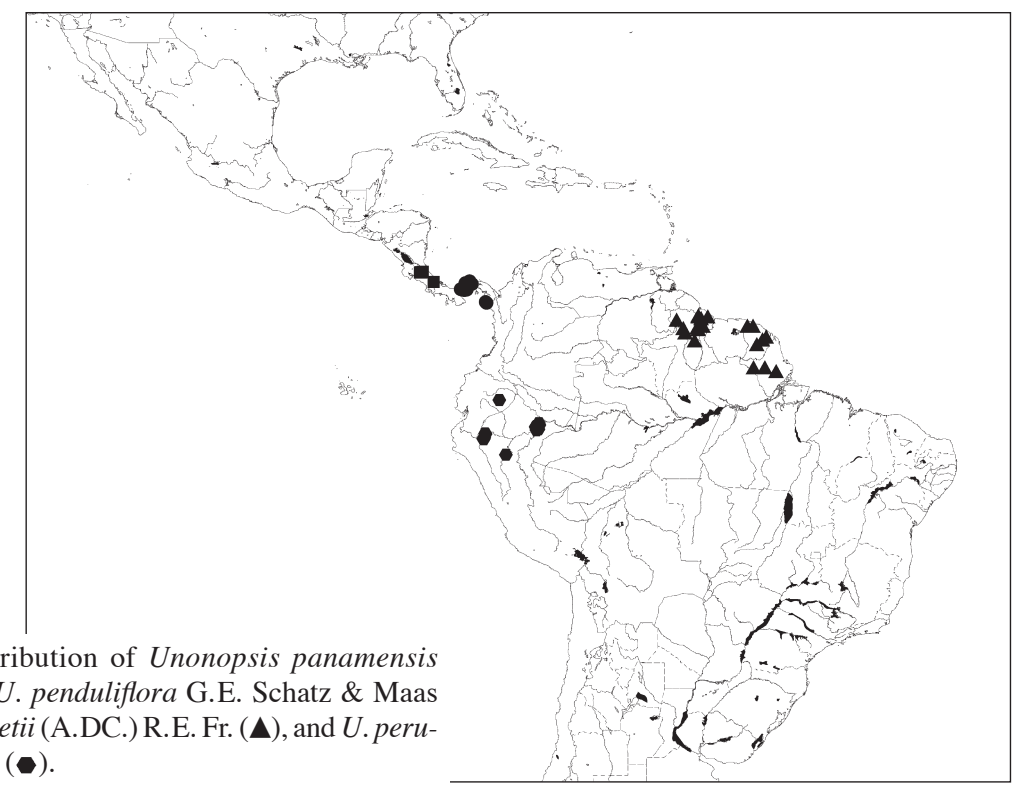

Map 16. Distribution of Unonopsis panamensis R.E. Fr. (๑), U. penduliflora G.E. Schatz \& Maas (匹), U.perrottetii (A.DC.) R.E. Fr. (ム), and U. peruviana R.E. Fr. ( ) 
Habitat \& Ecology - In forest. At elevations of 0-900 m. Flowering and fruiting: throughout the year.

Note - Unonopsis panamensis is best recognized by narrowly oblong-elliptic leaves and short pedicels (up to $20 \mathrm{~mm}$ long in fruit). See also under U. osae.

31. Unonopsis penduliflora G.E. Schatz \& Maas, spec. nov. - Fig. 29; Map 16

Species floribus longissime pedicellatis, petalis pro ratione maximis in sicco nigris bene distincta. - Typus: Hammel 12099 (holo CR; iso DUKE, 2 sheets, WIS, 2 sheets), Costa Rica, Heredia, near bridge on the road to La Virgén del Socorro, at edge of ridge overlooking step canyon down to Río Sarapiquí, 8 May 1982.

Small tree or shrub, 2-6 $\mathrm{m}$ tall, 2.5-4 cm diam.; young twigs sparsely to rather densely covered with erect, curly, short hairs and some appressed long hairs, soon glabrous. Leaves: petiole 7-15 mm long, 3-4 mm diam.; lamina narrowly elliptic to narrowly obovate, $25-50$ by $7-16 \mathrm{~cm}$ (leaf index $2.7-4$ ), chartaceous, densely verruculose, dull and greyish green above, green to pale brown below, sparsely covered with erect, curly hairs along primary and secondary veins to glabrous above, sparsely covered with appressed hairs along primary, secondary, and tertiary veins to glabrous below, base acute, apex acuminate (acumen 15-25 mm long), secondary veins distinct, curved, $12-17$ on either side of primary vein, raised above, angles with primary vein $35-50^{\circ}$, loop-forming at obtuse angles, smallest distance between loops and margin 1-3 mm, tertiary veins distinct, percurrent. Inflorescences on older branches, a single flower on a short axis to c. $5 \mathrm{~mm}$ long, axial internodes $1-2 \mathrm{~mm}$ long; upper bract at 1/10-1/6 from the base of the pedicel, broadly to shallowly ovate-triangular, 1-2 mm long, outer side rather densely to sparsely covered with appressed hairs; pedicels 50-115 $\mathrm{mm}$ long, c. $1 \mathrm{~mm}$ diam., fruiting pedicels to $3 \mathrm{~mm}$ diam., sparsely covered with appressed hairs to glabrous; flower buds broadly ovoid; sepals basally connate, deltate, $1.5-2.5$ by $1.5-4 \mathrm{~mm}$, outer side densely to rather densely covered with appressed brown hairs; petals creamy white in vivo, blackish in sicco, outer ones ovate-triangular, flat, 13-24 by 9-16 mm, outer side sparsely covered with appressed hairs, inner ones broadly ovate-triangular, concave, $10-11$ by $9-10 \mathrm{~mm}$, outer side glabrous except for hairy exposed part; stamens 1.5-2 mm long, connective shield glabrous; carpels 40-100, 1.5-2 mm long, densely covered with appressed golden brown hairs, ovule 1, lateral. Monocarps 2-30, green, maturing orange to red in vivo, brown to black in sicco, subglobose, 13-25 mm diam., sparsely covered with appressed hairs to finally glabrous, somewhat shrivelled in sicco, apex rounded, not apiculate, wall $0.3-0.4 \mathrm{~mm}$ thick, stipes $12-17$ by $1 \mathrm{~mm}$; fruiting receptacle subglobose to ovoid, 3-10 by 2-10 $\mathrm{mm}$, rather densely covered with erect hairs. Seed 1 , lateral, $12-15$ by $11-12$ by $8-10$ $\mathrm{mm}$, pale to dark brown.

Distribution - Costa Rica (Alajuela, Heredia, Limón).

Habitat \& Ecology — In non-inundated forest. At elevations of 70-1200 m. Flowering: March, May; fruiting: August to April.

Note - Unonopsis penduliflora is easily recognized by the extremely long pedicels (even exceeding $10 \mathrm{~cm}$ ). Its petals (sometimes almost $25 \mathrm{~mm}$ long) are much larger than in other species of Unonopsis, where petals commonly do not exceed $15 \mathrm{~mm}$. It is also noteworthy that the petals become black in sicco instead of brown or greyish 


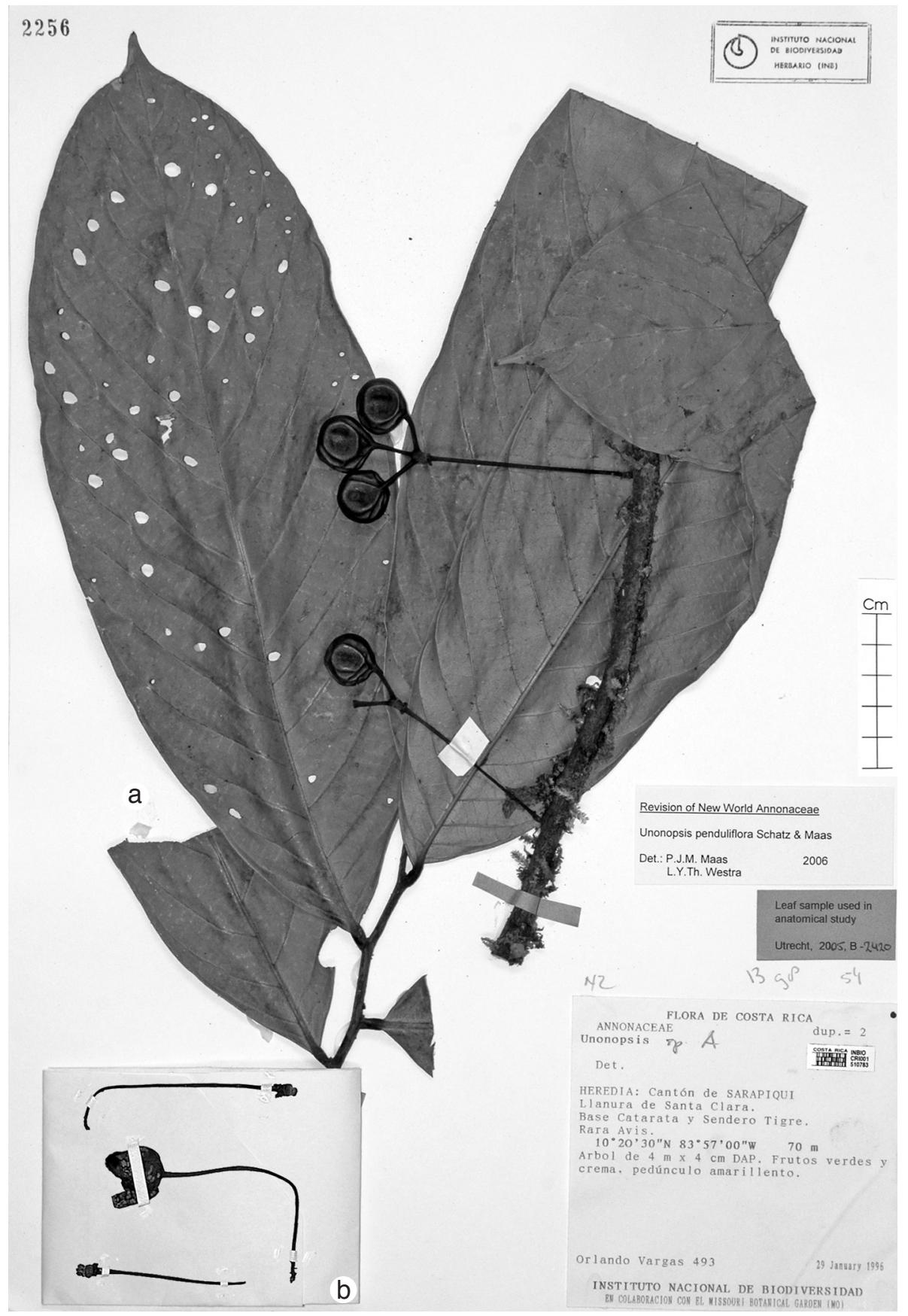

Fig. 29. Unonopsis penduliflora G.E. Schatz \& Maas. a. Fruiting twig; b. flowers (a: O. Vargas 493, INB; b: Hammel 12099, iso DUKE). 
(as in most other species of the genus). In that aspect they rather resemble flowers of some species of Cremastosperma.

Selection of other specimens (17) examined:

Costa RicA. Alajuela: Upper Río Sarapiquí, near Cariblanco and along road to Virgén del Socorro, 800 m, Burger \& Antonio 11112 (CR, F); canyon of Río Cariblanco and W slope and summit of ridge between Río Cariblanco and Quebrada Quicuyal, SW of Cariblanco, 840-950 m, Grayum et al. 6192 (CR, MO). Heredia: Parque Nacional Braulio Carillo, Cantón de Sarapiquí, Puesto El Ceibo, 750 m, Boyle et al. 2820 (INBIO, MO, U); Finca of Bernardo Gómez, Magsasay, 700 m, I.A. Chacón 181 (CR); between Quebrada Tigre and E fork of Río Sardinal, c. $9 \mathrm{~km} \mathrm{SW}$ of Las Horquetas, $600 \mathrm{~m}$, Grayum et al. 5039 (CR, MO); between Río Peje and Río Sardinalito, Atlantic slope of Volcán Barba, 700-950 m, Grayum et al. 6938 (CR, MO); SW corner of Zona Protectora, 12 km S of Magsasay, 800 m, Schatz et al. 683 (DUKE); Cantón de Sarapiquí, Llanura de Santa Clara, Catarata and Sendero Tigre, Rara Avis, 70 m, Vargas, O. 493 (INB). Limón: Reserva Indigena Talamanca, between Río Sukut and Río El Urén, road to Purisqui, 700 m, A. Chacón 109 (CR, MO, U).

\section{Unonopsis perrottetii (A.DC.) R.E. Fr. - Map 16}

Unonopsis perrottetii (A.DC.) R.E. Fr. (1900) 26; (1937) 255. - Annona ('Anona') perrottetii A.DC. (1832) 197. - Trigynaea perrottetii (A.DC.) Baill. (1868b) 179. - Type: Perrottet 65 (lecto G, 2 sheets; isolecto B, F, P), French Guiana, Mana, 1820 or 1821.

Trigynaea perrottetii (A.DC.) Baill. var. lanceolata Baill. (1868b) 179. - Unonopsis perrottetii (A.DC.) R.E. Fr. var. lanceolata (Baill.) R.E. Fr. (1900) 27. - Type: Mélinon 121 \& 426 (syn P), French Guiana, Maroni R., 1862.

Tree 5-20 m tall, 5-20 cm diam., trunk slightly and longitudinally fissured; young twigs densely covered with appressed hairs, soon glabrous. Leaves: petiole 2-7 mm long, 1-1.5 mm diam.; lamina generally narrowly elliptic, asymmetrical and slightly falcate, $9-20$ by $1.5-5 \mathrm{~cm}$ (leaf index 2.3-6), chartaceous, not or sparsely verruculose, shiny or dull and greyish olive above, yellowish brown below, glabrous above, glabrous below, except for some erect hairs along primary vein, base acute, apex acute to longacuminate (acumen 10-35 mm long), secondary veins indistinct, curved, 10-15 on either side of primary vein, raised above, angles with primary vein $55-75^{\circ}$, loop-forming at right to obtuse angles, smallest distance between loops and margin 1-3 $\mathrm{mm}$, tertiary veins indistinct, not percurrent. Inflorescences on older branches, rarely among leaves, a single rhipidium or compact thyrsoids, composed of 2 or 3 rhipidia; peduncle-like base 0-2 mm long; rhipidia 1- or 2-flowered, to 4 flowers in succession; sympodial rachis $2.5-5 \mathrm{~mm}$ long; upper bract at (1/10-)1/6-1/3 from the base of the pedicel, very broadly ovate-triangular, 1-2 $\mathrm{mm}$ long, outer side rather densely to densely covered with appressed hairs; pedicels $10-25 \mathrm{~mm}$ long, c. $1 \mathrm{~mm}$ diam., fruiting pedicels to $30 \mathrm{~mm}$ long, 2-3 mm diam., densely covered with appressed hairs; flower buds very broadly ovoid to globose; sepals basally connate, shallowly ovate-triangular, $1-1.5$ by $1.5-2.5 \mathrm{~mm}$, outer side densely covered with appressed hairs; petals cream to yellow in vivo, outer ones depressed ovate, concave, $4-9$ by $6-9 \mathrm{~mm}$, slightly longitudinally ribbed, outer side densely covered with appressed hairs, inner ones very broadly to depressed ovate, concave, $4-5\{-6\}$ by $4-6 \mathrm{~mm}$, outer side glabrous except for hairy exposed part; stamens $0.5-1 \mathrm{~mm}$ long, connective shield glabrous; carpels c. 30, c. $1 \mathrm{~mm}$ long, rather densely covered with appressed hairs, ovule 1, basal. Monocarps 5-30, green, maturing purple-black in vivo, black to dark brown in sicco, globose to broadly ellipsoid, 7-11(-15) by 6-10(-12) mm, glabrous, apex rounded, often asymmetrically 
apiculate (apiculum $0.1-0.2 \mathrm{~mm}$ long), wall $0.3-0.5\{-1\} \mathrm{mm}$ thick, stipes $6-12$ by 1-1.5 mm; fruiting receptacle depressed ovoid, 4-6 $\mathrm{mm}$ diam., densely covered with appressed hairs. Seeds 1 (or 2), basal, $6-8$ by $6-7$ by $5-7 \mathrm{~mm}$, reddish brown.

Distribution - Guyana, French Guiana, Brazil (Amapá).

Habitat \& Ecology - In non-inundated forest, on clayey to lateritic soil. At elevations of 0-800 m. Flowering: November to July, but mainly from May to July; fruiting: throughout the year, but mainly from February to June.

Vernacular names - French Guiana: Azau-udu (Paramaccan, Saramaccan), Mama yawé (Creole). Guyana: Arara (Arawak), Karashiri (Arawak), Yesi yariyari (Arawak).

Note - Unonopsis perrottetii is very distinctive by the slightly falcate, narrow leaves with inconspicuous secondary venation, resembling the foliage of Bocageopsis multiflora.

\section{Unonopsis peruviana R.E. Fr. - Map 16}

Unonopsis peruviana R.E. Fr. (1938) 739. - Type: Ll. Williams 1184 (holo F; fragment S), Peru, Loreto, Upper Río Nanay, Maquisapa, 4 July 1929.

Tree or rarely a shrub, 2.5-20 m tall; young twigs densely covered with erect and some appressed brown hairs. Leaves: petiole 3-6 mm long, 1-2 mm diam.; lamina narrowly obovate, sometimes narrowly elliptic, $11-19$ by $2.5-7 \mathrm{~cm}$ (leaf index (2.1-)2.9-4.3), chartaceous, almost bullate in living material, rather densely verruculose, dull above, grey to greyish green above, pale brown to greyish brown below, primary vein densely covered with erect, brown hairs, rest subglabrous above, sparsely covered with appressed hairs, mainly along primary and secondary veins, below, base acute, apex acuminate (acumen 5-10 mm long), secondary veins distinct, curved, 8-14 on either side of primary vein, impressed above, angles with primary vein $40-50^{\circ}$, loop-forming at right to obtuse angles, smallest distance between loops and margin 1-2 $\mathrm{mm}$, tertiary veins distinct, percurrent or not. Inflorescences on older branches, less often among leaves, compact to sublax, but only a single flower/fruit seen, axial internodes to $2 \mathrm{~mm}$ long; upper bract at 1/4-2/3 from the base of the pedicel, broadly ovate-triangular, 1-2 mm long, outer side densely covered with appressed hairs; pedicels 7-15 mm long, 1-2 mm diam., fruiting pedicels $10-25 \mathrm{~mm}$ long, 3-5 mm diam., densely to rather covered with appressed and erect brown hairs; flower buds subglobose; sepals completely connate into a cup-like structure 6-8 mm diam., 1-3 mm long, outer side densely covered with appressed hairs; petals white to yellow in vivo, outer ones broadly ovate, concave, $8-14$ by 7-12 mm, outer side densely covered with appressed hairs, inner ones broadly ovate, distinctly concave, $8-12$ by $7-10 \mathrm{~mm}$, outer side glabrous except for hairy exposed part; stamens 2.5-3 mm long, connective shield glabrous; carpels 5-25, 3-5 mm long, densely covered with appressed hairs, ovules 2-5, lateral. Monocarps 5-50, green, maturing yellow to orange in vivo, dull brown in sicco, globose to ellipsoid, $12-25$ by 12-17 mm, sparsely covered with appressed hairs to finally glabrous, apex rounded or apiculate (apiculum $<0.2 \mathrm{~mm}$ long), wall $0.4-0.6\{-2\} \mathrm{mm}$ thick, stipes $3-10$ by $2 \mathrm{~mm}$; fruiting receptacle depressed globose to globose, 8-12 $\mathrm{mm}$ diam., densely to rather densely covered with appressed and erect hairs. Seeds 1-4, lateral, 8-15 by $7-10$ by $5-7 \mathrm{~mm}$, dark brown. 
Distribution - Amazonian Peru (Amazonas, Loreto, San Martín) and Ecuador (Pastaza).

Habitat \& Ecology - In primary non-inundated forest, sometimes in swampy forest, on sandy or sometimes on clayey soil. At elevations of 0-400(-970) m. Flowering: June, July, November, December; fruiting: January, February, April, from June to August.

Vernacular names - Peru: Bara-caspi, Espintana, Icoja, Icoja negra, Yais.

Note - Unonopsis peruviana, with its main distribution in Amazonian Peru, is readily recognized by the long-persistent, erect and appressed, brown hairs on the leafy twigs, and the large fruiting receptacle. The most noteworthy feature are the sepals completely connate into a cup-like structure, by which it is clearly distinct from its possibly closest relative $U$. guatterioides.

\section{Unonopsis pittieri Saff. ex Standl. - Map 17}

Unonopsis pittieri Saff. ex Standl. (1925) 102. - Type: Pittier 3871 (holo US, 2 sheets), Panama, Colón, along Río Fato, above Nombre de Dios, 10-100 m, 8-10 July 1911.

Unonopsis schippii R.E. Fr. (1937) 254, syn. nov. - Type: Schipp 1203 (holo S; iso A, G, GH, K, MICH, MO, NY, UC, Z), Belize, Jacinto Hills, 65 m, 8 September 1933.

Tree 5-25 $\mathrm{m}$ tall, 7.5-50 cm diam.; young twigs sparsely covered to rather densely with appressed hairs, soon glabrous. Leaves: petiole 4-10 mm long, 1-3(-4) mm diam.; lamina narrowly elliptic, rarely narrowly obovate, symmetrical, sometimes slightly asymmetrical, $12-41$ by $4-14 \mathrm{~cm}$ (leaf index $2.5-4$ ), chartaceous, rather densely to densely verruculose, often concentrated along primary and secondary veins, or not verruculose, mostly dull above, brown to green or greyish above and below, glabrous or with some scattered appressed and erect hairs along primary and secondary veins on both sides, base acute to obtuse, rarely cordate, apex acuminate (acumen 5-20 mm long), secondary veins distinct, curved, 10-16 on either side of primary vein, impressed, flat, or slightly raised above, angles with primary vein $40-60^{\circ}$, loop-forming at right to obtuse angles, or not loop-forming, smallest distance between loops and margin $1-3(-5) \mathrm{mm}$, tertiary veins distinct or indistinct, percurrent. Inflorescences on older branches, sometimes among leaves, sublax to lax, often panicle-like, occasionally compact, composed of (1-)2-10 rhipidia; peduncle-like base $0-5(-10) \mathrm{mm}$ long; axial internodes $<1-6 \mathrm{~mm}$ long; rhipidia 2- or 3-flowered, to 7(-10) flowers in succession; sympodial rachis $15-35 \mathrm{~mm}$ long, with internodes $(<1-) 2-5 \mathrm{~mm}$ long, and with free pedicel remnants $0-2 \mathrm{~mm}$ long; upper bract at $1 / 5-2 / 5$ from the base of the pedicel, depressed ovate-triangular, 1-2 mm long, outer side sparsely to densely covered with appressed hairs; pedicels 3-15 mm long, 1-1.5 mm diam., fruiting pedicels 7-45 $\mathrm{mm}$ long, 1-3(-6) mm diam., sparsely to rather densely, rarely densely covered with appressed hairs; flower buds subglobose to depressed ovoid; sepals basally connate, shallowly ovate-triangular, 1-2 by $2-4 \mathrm{~mm}$, outer side sparsely to densely covered with appressed hairs; petals green, yellow, orange to cream in vivo, outer ones ovate, flat, (4-)6-9 by 4-8 mm, outer side densely to rather densely covered with appressed hairs, inner ones broadly ovate, concave, $4-7$ by 3-6 mm, outer side glabrous except for hairy exposed part; stamens 1-2 mm long, connective shield glabrous; carpels 10-25, 1-2 mm long, densely to sparsely covered with appressed hairs, ovule 1, lateral. 
Monocarps 1-15(-50), green, maturing red, orange-red, purple-black to black in vivo, brown in sicco, globose or almost so, 11-20(-25) mm diam., sparsely covered with appressed hairs to finally glabrous, apex rounded or apiculate (apiculum $0.5-1 \mathrm{~mm} \mathrm{long}$ ), wall $0.2-0.5(-1.5) \mathrm{mm}$ thick, stipes $6-20$ by $1-3 \mathrm{~mm}$; fruiting receptacle globose to depressed globose, $3-5$ by $4-9 \mathrm{~mm}$, sparsely to rather densely covered with appressed hairs, soon glabrous. Seed 1, lateral, $10-20$ by $9-18$ by $5-14 \mathrm{~mm}$, brown.

Distribution - Central America (Guatemala, Honduras, Belize, Nicaragua, Costa Rica, Panama) and (?) Colombia (Antioquia).

Habitat \& Ecology - In non-inundated forest. At elevations of 0-600(-800) m. Flowering and fruiting: throughout the year.

Vernacular names - Guatemala: Anono amarillo. Honduras: Carbón de montaña. Panama: Yaya blanca.

Notes - Unonopsis pittieri is best recognized among the Central American species of the genus by its strongly branched inflorescence.

Material from El Llano-Carti Rd., Comarca de San Blas, Panama, is somewhat aberrant by unusually large monocarps (up to $25 \mathrm{~mm}$ diam.).

Callejas et al. 2719 (HUA, MO, NY, U) from Colombia, Antioquia, Mun. Frontino, Vereda Venados, Parque Nacional de las Orquídeas, 830 m, 28 Oct. 1986, has similarly large monocarps (20-25 $\mathrm{mm}$ diam.) and possibly represents an isolated occurrence of $U$. pittieri outside Central America.

Specimens from Guatemala and Nicaragua, formerly referred to U. schippii, tend to differ from material from Panama and Costa Rica by greyish leaves and a more congested inflorescence. As there are intergrades we found insufficient ground for maintaining $U$. schippii as a separate species.

Robles 1868 (F, MO, $\mathrm{U}$ ) from Costa Rica is deviating in having 3-seeded monocarps, a feature not encountered otherwise in U. pittieri.

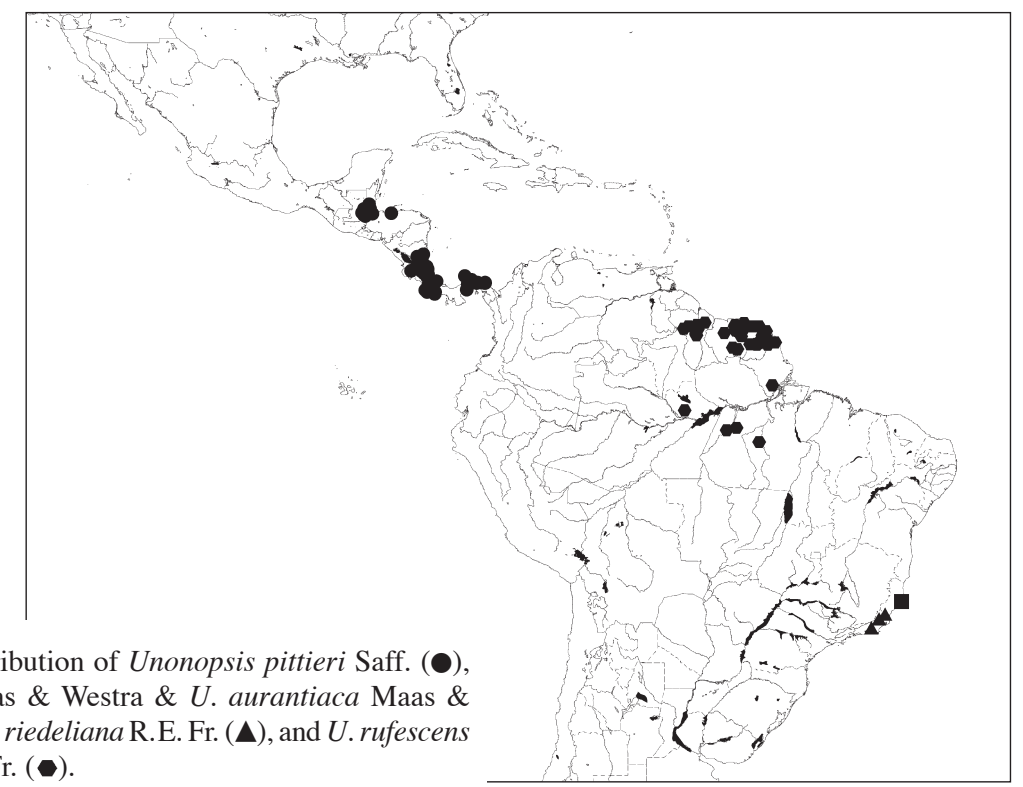

Map 17. Distribution of Unonopsis pittieri Saff. (•), $U$. renati Maas \& Westra \& U. aurantiaca Maas \&

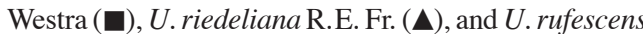
(Baill.) R.E. Fr. ( $)$. 
35. Unonopsis renati Maas \& Westra, spec. nov. - Fig. 30; Map 17

Ab omnibus speciebus in hac regione monocarpiis breviter stipitatis pericarpio crasso differt. - Typus: Sucre 8355 (holo U; iso RB), Brazil, Espírito Santo, Reserva de Linhares, DOCEMADE, 1 February 1972.

Tree c. $18 \mathrm{~m}$ tall; young twigs densely covered with appressed to erect hairs, soon glabrous. Leaves: petiole 5-10 $\mathrm{mm}$ long, 2-2.5 mm diam.; lamina narrowly elliptic to narrowly obovate, $15-25$ by $5-8 \mathrm{~cm}$ (leaf index $2.5-3.3$ ), chartaceous, sparsely to densely verruculose, shiny or dull above, brown to pale brown above, brown below, sparsely to rather densely covered with appressed hairs above, sparsely to rather densely covered with appressed hairs below, base acute, apex acuminate (acumen 10-20 mm long), secondary veins distinct, curved, 11-13 on either side of primary vein, impressed above, angles with primary vein $45-55^{\circ}$, loop-forming at obtuse angles, smallest distance between loops and margin 2.5-4 mm, tertiary veins distinct, percurrent. Inflorescences on older branches, compact, composed of 2-5? rhipidia, peduncle-like base $0-2 \mathrm{~mm}$; rhipidia 2- or 3-flowered, to c. 12 flowers in succession, sympodial rachis to $10 \mathrm{~mm}$ long; upper bract at c. 1/4 from the base of the pedicel, broadly ovate-triangular, 1-2 mm long, outer side densely covered with appressed yellowish brown hairs; pedicels 11-17 $\mathrm{mm}$ long, $1 \mathrm{~mm}$ diam., fruiting pedicels to $30 \mathrm{~mm}$ long, to $4 \mathrm{~mm}$ diam., densely covered with appressed yellowish brown hairs; flower buds very broadly ovoid; sepals basally connate, shallowly ovate-triangular, $1.5-2$ by $2-2.5 \mathrm{~mm}$, outer side densely covered with appressed yellowish brown hairs; petals pale green in vivo, outer ones ovate, concave, $5-8$ by $5-7 \mathrm{~mm}$, outer side densely covered with appressed yellowish brown hairs, inner ones broadly ovate, strongly concave, 4-6 by $4-6 \mathrm{~mm}$, outer side glabrous except for hairy exposed part; stamens c. $1 \mathrm{~mm}$ long, connective shield glabrous; carpels 25-30, c. $1 \mathrm{~mm}$ long, densely covered with appressed hairs, ovule 1, basal. Monocarps 6-8, dark brown in vivo, brown in sicco, globose, 17-20 mm diam., densely covered with appressed and erect yellowish brown hairs, apex rounded, not apiculate, wall 1-2.5 mm thick, stipes $3-5$ by $3-4 \mathrm{~mm}$; fruiting receptacle very broadly ovoid, 9-10 mm diam., densely covered with appressed hairs. Seed 1, basal, $13-15$ by $12-13$ by $11-13 \mathrm{~mm}$, reddish brown.

Distribution - Brazil (Espírito Santo).

Habitat \& Ecology - In non-inundated forest ('mata de tabuleiro'). At sea level. Flowering: September; fruiting: February.

Vernacular name - Brazil: Pindaíba.

Notes - Unonopsis renati can be distinguished from other species occurring in SE Brazil (viz. U. bauxitae, U. riedeliana, and $U$. sanctae-teresae) by its relatively thick fruit wall (up to $2.5 \mathrm{~mm}$ thick) and by the short stipes. Furthermore, the young leafy twigs are covered with appressed to erect (instead of only appressed) hairs. Both $U$. aurantiaca and $U$. renati are endemics of the same area: $U$. aurantiaca differing from the other in the same characters as just mentioned, but particularly also by the orange-coloured petals,

This species has been named in honour of Renato Moraes de Jesus, Director of the Linhares Forest Reserve, who actively stimulated our work. He has been assisting us since 1986 by sending many interesting collections of Annonaceae to Utrecht and by 


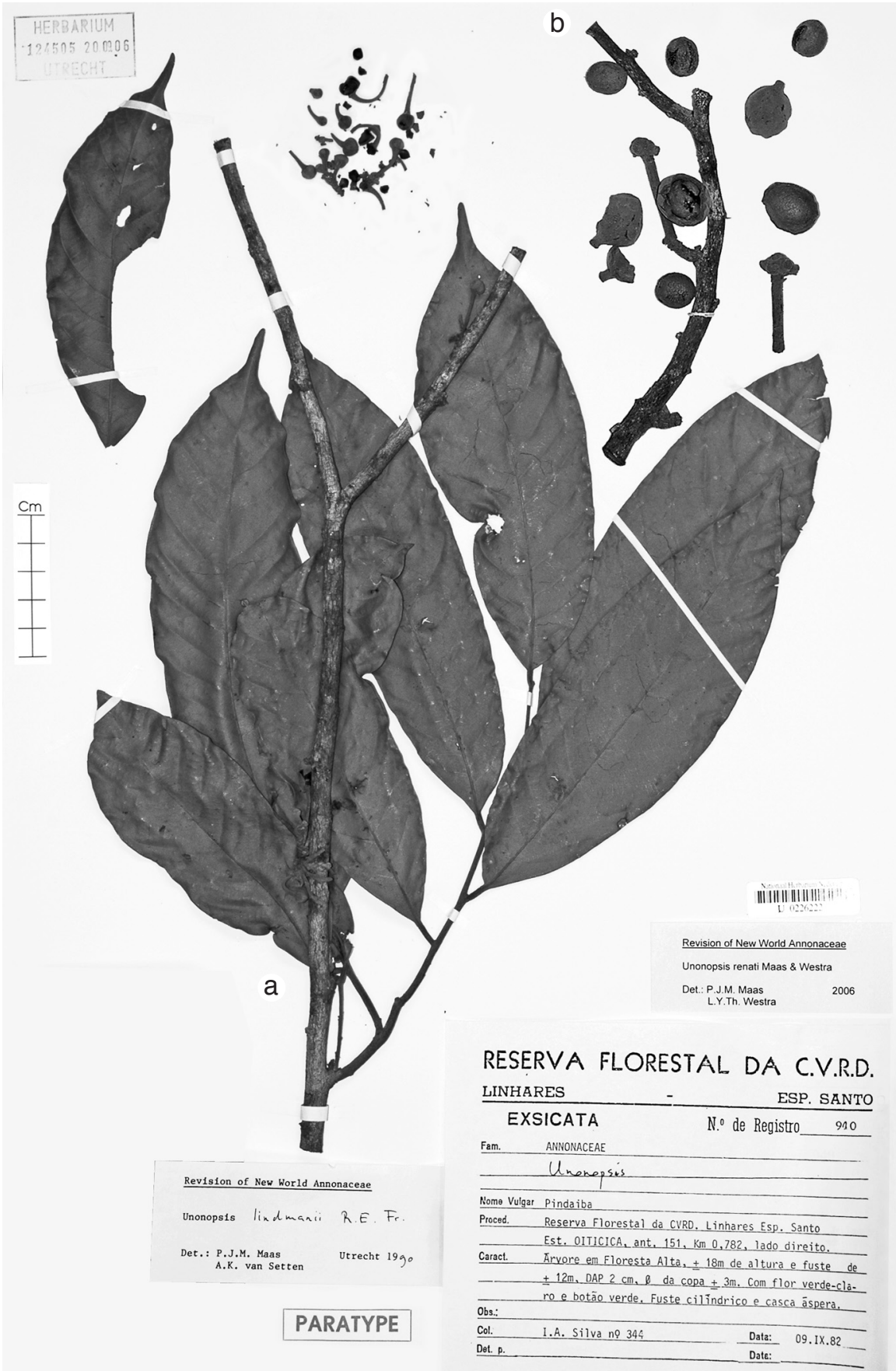

Fig. 30. Unonopsis renati Maas \& Westra. a. Flowering twig; b. part of fruiting twig (a: I.A. Silva 344, U; b: Sucre 8355, holo U). 
providing all kinds of facilities (like housing and transportation) during the first author's visits to the CVRD Reserve.

Other specimen studied:

BRAZIL. Espírito Santo: Linhares, Reserva Florestal da CVRD, Estrada Oiticica, ant. 151, km. 0.782, I.A. Silva 344 (K, U).

\section{Unonopsis riedeliana R.E. Fr. - Map 17}

Unonopsis riedeliana R.E. Fr. (1906) 11, t. 2, f. 1-6; (1937) 253. - Type: Riedel s.n. (holo S; iso A, K, LE, M, MO), Brazil, Rio de Janeiro, Mandioca ('in silvis Mandiocca'), October 1823.

Tree 6-10 m tall, c. $5 \mathrm{~cm}$ diam.; young twigs densely covered with appressed pale brown hairs, soon glabrous. Leaves: petiole 3-6 mm long, 1-1.5 mm diam.; lamina narrowly oblong-elliptic to narrowly ovate, slightly asymmetrical, $4-17$ by $1.5-4 \mathrm{~cm}$ (leaf index 3-5), chartaceous, somewhat shiny above, smooth to densely verruculose along primary and secondary veins, brownish to greyish green above, greyish green below, glabrous above (except for the youngest leaves with appressed hairs above), primary and secondary veins rather densely covered with appressed pale brown hairs to glabrous below, base acute, apex long-acute to acuminate (acumen 5-20 mm long), secondary veins indistinct, curved, 11-15 on either side of primary vein, flat to slightly raised above, angles with primary vein $40-50^{\circ}$, loop-forming at right to obtuse angles, smallest distance between loops and margin 1-3 mm, tertiary veins indistinct, percurrent. Inflorescences on older branches, compact, less often sublax, composed of 3-5 rhipidia; peduncle-like base $0-2 \mathrm{~mm}$ long; axial internodes $>1-2 \mathrm{~mm}$ long; rhipidia 2- or 3-flowered, to 10 flowers in succession; sympodial rachis to $10 \mathrm{~mm}$ long; upper bract at c. $1 / 5$ from the base of the pedicel, very broadly ovate, $1-1.5 \mathrm{~mm}$ long, outer side densely covered with appressed pale brown hairs; pedicels 10-35 mm long, c. $1 \mathrm{~mm}$ diam., densely covered with appressed to erect pale brown hairs; flower buds subglobose; sepals basally connate, very broadly to shallowly ovate-triangular, $1-2$ by 2-4 mm, outer side densely covered with appressed pale brown hairs; petals yellowish in vivo, outer ones ovate to broadly so, concave, $6-10$ by $6-7 \mathrm{~mm}$, outer side rather densely covered with appressed pale brown hairs, inner ones broadly ovate, concave, 5-8 by 4-7 mm, outer side glabrous except for hairy exposed part; stamens c. $1 \mathrm{~mm}$ long, connective shield papillate; carpels 30-50, c. $1 \mathrm{~mm}$ long, densely covered with appressed yellowish white hairs, ovule 1, lateral. Fruits not seen.

Distribution - Brazil (Rio de Janeiro).

Habitat \& Ecology - In non-inundated forest (Atlantic rain forest). At elevations of c. $200 \mathrm{~m}$ (only once recorded). Flowering: October, November; fruiting: unknown.

Vernacular names - Brazil: Imbiú branco, Imbiú preto.

Notes - For the differences between $U$. riedeliana and $U$. bauxitae see under the latter.

We are not completely sure about the identity of P.P. Oliveira 232 (SPF) from Rio das Ostras, Rio de Janeiro, Brazil, of which we have only seen a photograph. It may belong here but the leaves (venation and width) seem to be different.

Other specimens examined:

BRAZIL. Rio de Janeiro: Mun. Cachoeira de Macacu, Estação Ecológico do Paraíso, 200 m, Kurtz et al. RB 328311 (RB); Monte Sinai, G. Portella, E of Rio de Janeiro, Nunes RB 83981 (RB). 


\section{Unonopsis rufescens (Baill.) R.E. Fr. - Plate 2b, 5c; Map 17}

Unonopsis rufescens (Baill.) R.E. Fr. (1900) 27; (1937) 256. - Trigynaea rufescens Baill. (1868b) 180. - Type: Mélinon 19 (holo P; iso G, K, P), French Guiana, Maroni R., 1864.

Tree (3.5-)6-22 m tall, 5-30(-60) cm diam., sometimes with red to orange exudate; trunk shallowly fissured; young twigs densely covered with appressed hairs, soon glabrous. Leaves: petiole 3-7 $\mathrm{mm}$ long, 2-2.5 mm diam.; lamina narrowly elliptic to elliptic, sometimes obovate to narrowly so, $10-18$ by $3-7 \mathrm{~cm}$ (leaf index $1.9-2.9$ ), chartaceous, densely to rather densely verruculose, greyish brown to greyish olive above, greyish olive below, glabrous above, but primary vein densely covered with erect hairs, sparsely covered with erect hairs below, but primary vein and secondary veins densely so, base acute, apex acuminate (acumen 2-30 mm long), secondary veins distinct, curved, 8-14 on either side of primary vein, impressed above, angles with primary vein $45-70^{\circ}$, loop-forming at obtuse angles, smallest distance between loops and margin 2-5 mm, tertiary veins indistinct, percurrent. Inflorescences on older branches, lax and usually elongate or panicle-like, the main axis often between 60-110 mm long and often more or less zigzagging, composed of 7-20(-35) rhipidia; peduncle-like base 0-25 mm long; axial internodes 3-12 mm long; rhipidia 1-3-flowered, to 12 flowers in succession; sympodial rachis $2-10(-20) \mathrm{mm}$ long, with internodes 1-2(-4) mm long; upper bract at 1/3-1/2 from the base of the pedicel, broadly to depressed ovate, 1-2.5 mm long, outer side densely covered with appressed hairs; pedicels 7-23 mm long, 1-1.5 mm diam., fruiting pedicels to $30 \mathrm{~mm}$ long, to $3 \mathrm{~mm}$ diam., densely covered with appressed hairs; flower buds very broadly to depressed ovoid, glaucous; sepals connate for c. $2 / 3$ of their length, very broadly to shallowly ovate-triangular, $1-1.5$ by $2-3 \mathrm{~mm}$, outer side densely covered with appressed hairs; petals cream to white in vivo, outer ones broadly to depressed ovate, concave, $3.5-6$ by 4-6 mm, outer side densely covered with appressed hairs, inner ones ovate to broadly ovate, concave, $3.5-4.5$ by $2.5-4 \mathrm{~mm}$, outer side glabrous except for hairy exposed part; stamens 1-1.5 mm long, connective shield glabrous; carpels c. 15, 1.5-2 mm long, densely covered with appressed hairs, ovule 1, lateral near the apex. Monocarps $5-15$, glaucous green, maturing purplish black with a glaucous cover in vivo, purplish grey to sometimes dark brown, often glaucous in sicco, globose, 11-20 mm diam., glabrous, apex rounded or sometimes apiculate (apiculum $<0.5 \mathrm{~mm}$ long), wall 1-2.5 $\mathrm{mm}$ thick, stipes 5-11(-20) by $1-3 \mathrm{~mm}$; fruiting receptacle depressed ovoid, 3-10 $\mathrm{mm}$ diam., densely covered with appressed hairs. Seed 1 , lateral to basal, 9-11 by $9-11$ by 7-10 mm, dark red to reddish black.

Distribution - Guyana, Suriname, French Guiana, and Brazil (Amapá, Amazonas, Pará).

Habitat \& Ecology - In non-inundated forest, on brown or white sand, lateritic, bauxite, or loamy soil. At elevations of 0-700 m. Flowering: April to December, but mainly from June to October; fruiting: throughout the year, but mainly in September, October, February.

Vernacular names - French Guiana: A teki uma udu (Boni, Creole), Azau-udu (Paramaccan, Saramaccan), Mamanyaret (Creole), Maman yawé, Pina'itay (Wayãpi), Waï (Wayani). Guyana: Arara (Arawak), Gagoti. Suriname: A kusuwe fuuta (Saramaccan), Amose-rang (Carib), Amosérian (Carib), Apotai wewe (Carib), Araid'a (Carib), Araidya 
(Carib), Araita (Carib), Aratia (Carib), Boszuurzak (Surinamese Dutch), Busisunsaka (Aucan), Gaan busi azau-udu (Saramaccan), Kleinbladige yariyari (Surinamese Dutch), Mwaba (Djuka), Panta (Sranang), Peperhout (Surinamese Dutch), Pepre udu (Sranang), Pepre sowtu (Sranang), Pikapika (Sranang), Yariyari (Sranang), Yeseredan (Arawak), Yeseredan hohorodikoro (Arawak), Zuurzak (Surinamese Dutch).

Notes - In flowering stage U.rufescens is often easy to recognize by the lax multirhipidiate inflorescences, the axial internodes being markedly longer than internodes of sympodial rachises (see Plate $2 b$ ).

Unonopsis rufescens, as well as $U$. floribunda and $U$. glaucopetala, is characterized by a strongly branched and many-flowered inflorescence. Unonopsis floribunda occurs over a large part of the Amazon Region, whereas the other two species have their main centre of distribution in the three Guianas. Unonopsis rufescens differs from $U$. floribunda by the glaucous monocarps (vs brown or blackish in sicco) and by the thicker monocarp wall (1-2.5 vs $0.2-0.3 \mathrm{~mm})$. Unonopsis rufescens differs from $U$. glaucopetala by the smaller leaves $(10-18$ by $3-7$ vs $15-45$ by $5-13 \mathrm{~cm}$ ) and also by the glaucous monocarps (vs dark reddish brown to black in U. glaucopetala).

Material from Amazonas, Brazil, tends to have somewhat larger monocarps (15-20 $\mathrm{mm}$ diam.) and stipes (to $20 \mathrm{~mm}$ long) than is average in this species.

Material from Costa Rica had been incorrectly identified as U. rufescens (Zamora V. et al., 2000: 248), but is actually referable to U. hammelii.

38. Unonopsis sanctae-teresae Maas \& Westra, spec. nov. - Fig. 31; Plate 5d; Map 18

Unonopsi bauxitae proxima sed foliis crassioribus en majoribus, monocarpiis stipitibusque minoribus differt. - Typus: Fiaschi et al. 706 (holo SPF), Brazil, Espírito Santo, Mun. Santa Teresa, Estação Biológica de Santa Lúcia, trilha do Sagui, trail to the grave of Sr. Ruschi, close to Rio Timbui, 720 m, 10 March 2001.

Tree 4-10 m tall, 10-20 cm diam.; young twigs sparsely covered with appressed hairs, soon glabrous. Leaves: petiole 5-7 mm long, 2-3 mm diam.; lamina generally narrowly elliptic to narrowly obovate, $13-25$ by $5-9 \mathrm{~cm}$ (leaf index $2.4-3.2$ ), chartaceous, rather densely to sparsely verruculose on both sides, shiny to dull above, pale brown to brown above, brown below, glabrous above, sparsely covered with appressed hairs to glabrous below, base acute to obtuse, apex acuminate (acumen 5-20 mm long), secondary veins distinct, curved, 10-13 on either side of primary vein, impressed or sometimes raised above, angles with primary vein $55-60^{\circ}$, loop-forming at right to obtuse angles, smallest distance between loops and margin $2-4 \mathrm{~mm}$, tertiary veins distinct, percurrent. Inflorescences on older branches, compact, composed of 1 or 2 (or 3?) rhipidia; peduncle-like base $0-1 \mathrm{~mm}$ long; rhipidia 1- or 2-flowered, to c. 4 flowers in succession; sympodial rachis to $4 \mathrm{~mm}$ long; upper bract at $1 / 4-1 / 3$ from the base of the pedicel, depressed ovate, $1.5-3 \mathrm{~mm}$ long, outer side densely covered with appressed hairs; pedicels 10-25 $\mathrm{mm}$ long, 1-2 mm diam., fruiting pedicels to $30 \mathrm{~mm}$ long, to $3 \mathrm{~mm}$ diam., densely covered with appressed hairs; flower buds very broadly ovoid, slightly pointed; sepals connate for over half of their length, shallowly ovatetriangular, $2-3$ by $4-5 \mathrm{~mm}$, outer side densely covered with appressed hairs; petals cream to yellow in vivo, outer ones broadly ovate, concave, $5-11$ by $8-9\{-12\} \mathrm{mm}$, 


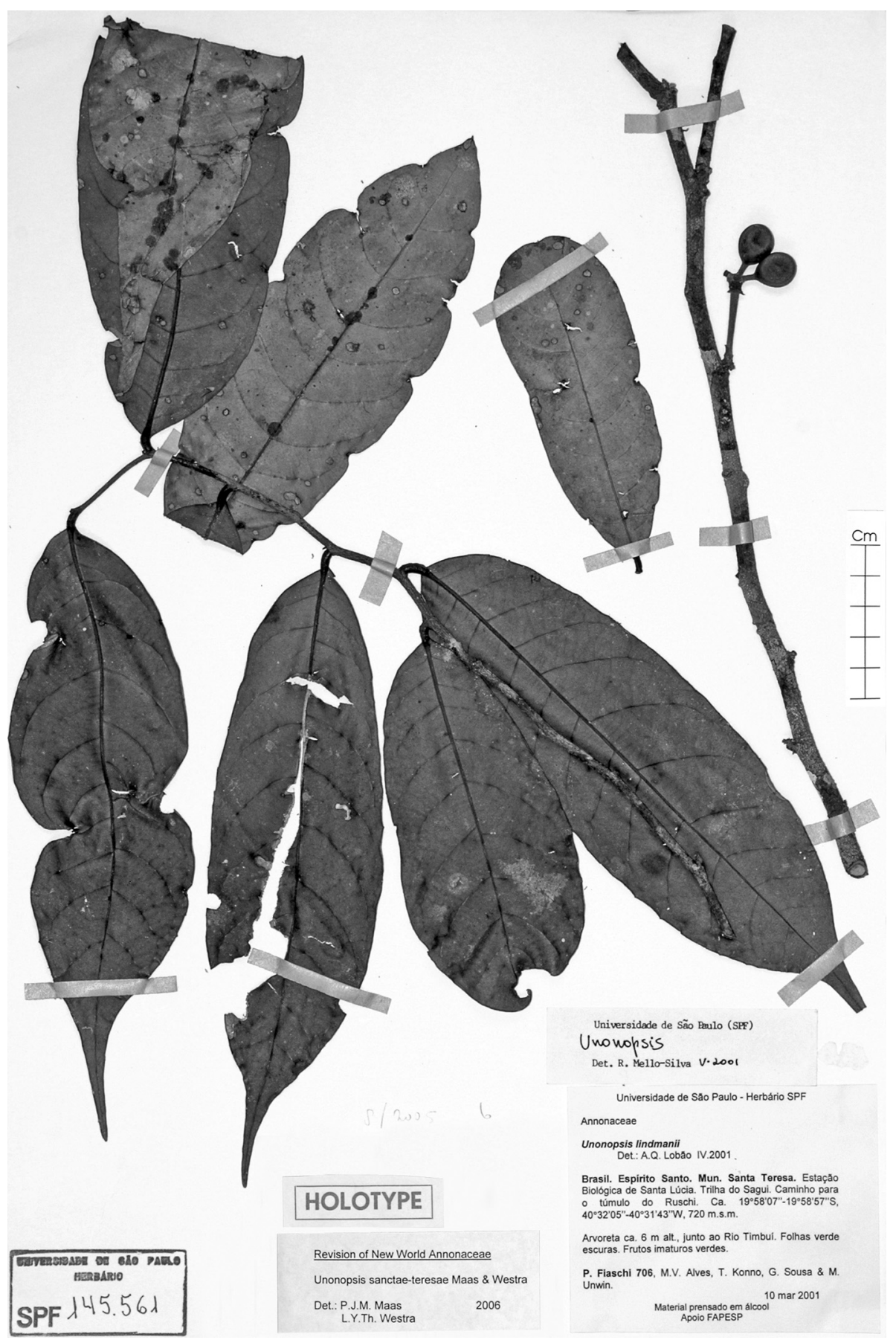

Fig. 31. Unonopsis sanctae-teresae Maas \& Westra. Fruiting twig (Fiaschi et al. 706, holo SPF). 
outer side densely covered with appressed hairs, inner ones broadly ovate, strongly concave, $5-9$ by $6-7\{-8\} \mathrm{mm}$, outer side glabrous except for hairy exposed part; stamens 1.5-2 mm long, connective shield glabrous or margins covered with some white hairs; carpels 30-50, 1-2 mm long, densely covered with appressed hairs, ovule 1, basal. Monocarps 5-30, green to yellowish green in vivo, brown in sicco, globose to ellipsoid, $13-15$ by $10-12 \mathrm{~mm}$, rather densely covered with appressed hairs, soon glabrous, apex rounded, asymmetrically apiculate (apiculum $0.5-1 \mathrm{~mm}$ long), wall $0.4-0.5 \mathrm{~mm}$ thick, stipes $5-7$ by $1-2 \mathrm{~mm}$; fruiting receptacle depressed ovoid, c. 3 by $6 \mathrm{~mm}$, densely covered with appressed hairs. Seed 1, basal, c. 13 by 11 by $7 \mathrm{~mm}$, dark, shiny brown.

Distribution - Brazil (Espírito Santo).

Habitat \& Ecology - In non-inundated, high forest ('mata atlântica'), with many palms and terrestrial and epiphytic Bromeliaceae, on brown sand. At elevations of 700-800 m. Flowering: February, September, October; fruiting: February, March, October.

Note - Unonopsis sanctae-teresae is probably closest to the recently described $U$. bauxitae (from Minas Gerais), both sharing hairy monocarps and pointed flower buds. It differs, however, by smaller monocarps (13-15 vs $15-25 \mathrm{~mm}$ ) with shorter stipes (5-7 vs $10-15 \mathrm{~mm}$ ), and by the more numerous monocarps (5-30 vs $1-5)$.

Other specimens examined:

BRAZIL. Espírito Santo: Mun. Santa Teresa, Estação Biológica de Santa Lúcia, 800 m, Maas et al. 8831, 8832 (MBML, U), Thomaz 789, 792 (MBML, SPF); Santa Teresa, Reserva Biológica de Nova Lombardia, 700 m, Peixoto et al. 3503 (MO, U).

\section{Unonopsis sericea Maas \& Westra, spec. nov. - Fig. 32; Map 18}

Species foliis subtus dense sericeis distincta. - Typus: Soejarto \& Rentería A. 3605 (holo HUA; iso COL, F, GH, MO, NY, RB), Colombia, Antioquia, Mun. Anorí, Corregimiento Providencia, Buenos Aires, 4 km from Providencia, 500 m, 11 December 1972.

Tree c. $25 \mathrm{~m}$ tall, c. $25 \mathrm{~cm}$ diam., with dark reddish brown exudate; young twigs distinctly ridged, densely covered with appressed pale brownish white hairs, soon glabrous, Leaves: petiole 5-10 mm long, 2-3 mm diam.; lamina narrowly elliptic, 17-21 by 5-7 cm (leaf index 2.8-3.4), chartaceous, sparsely verruculose, dark to greenish brown above, pale brown below, rather densely covered with appressed hairs above, densely covered with appressed pale brownish white hairs below, base acute, apex shortly acuminate (acumen $<5 \mathrm{~mm}$ long), secondary veins distinct, curved, $15-18$ on either side of primary vein, impressed above, angles with primary vein $40-45^{\circ}$, loopforming at obtuse angles, smallest distance between loops and margin c. $1 \mathrm{~mm}$, tertiary veins distinct, percurrent. Inflorescences on older branches or less often among leaves, compact, composed of 2(-several?) rhipidia; upper bract at 1/8-1/4 from the base of the pedicel, depressed ovate, c. $2 \mathrm{~mm}$ long, outer side densely covered with appressed pale brownish white hairs; fruiting pedicels $25-50 \mathrm{~mm}$ long, 2-3 mm diam., sparsely covered with appressed pale brownish white hairs; flower buds not seen; sepals free, depressed ovate, $1.5-2$ by $2-2.5 \mathrm{~mm}$, outer side densely covered with appressed pale brownish white hairs; petals, stamens, and carpels not seen. Monocarps (2-)5-20, dark green in vivo, brown and slightly shrivelled in sicco, depressed globose to globose, 


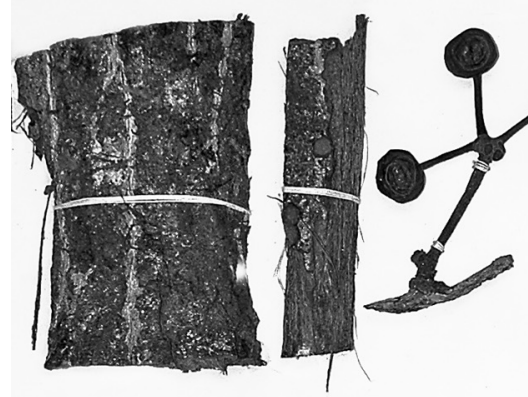

018276

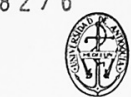

HERBAR IO

UNIVERSIDAD DE ANTIOQUIA

Medellin, Colombia

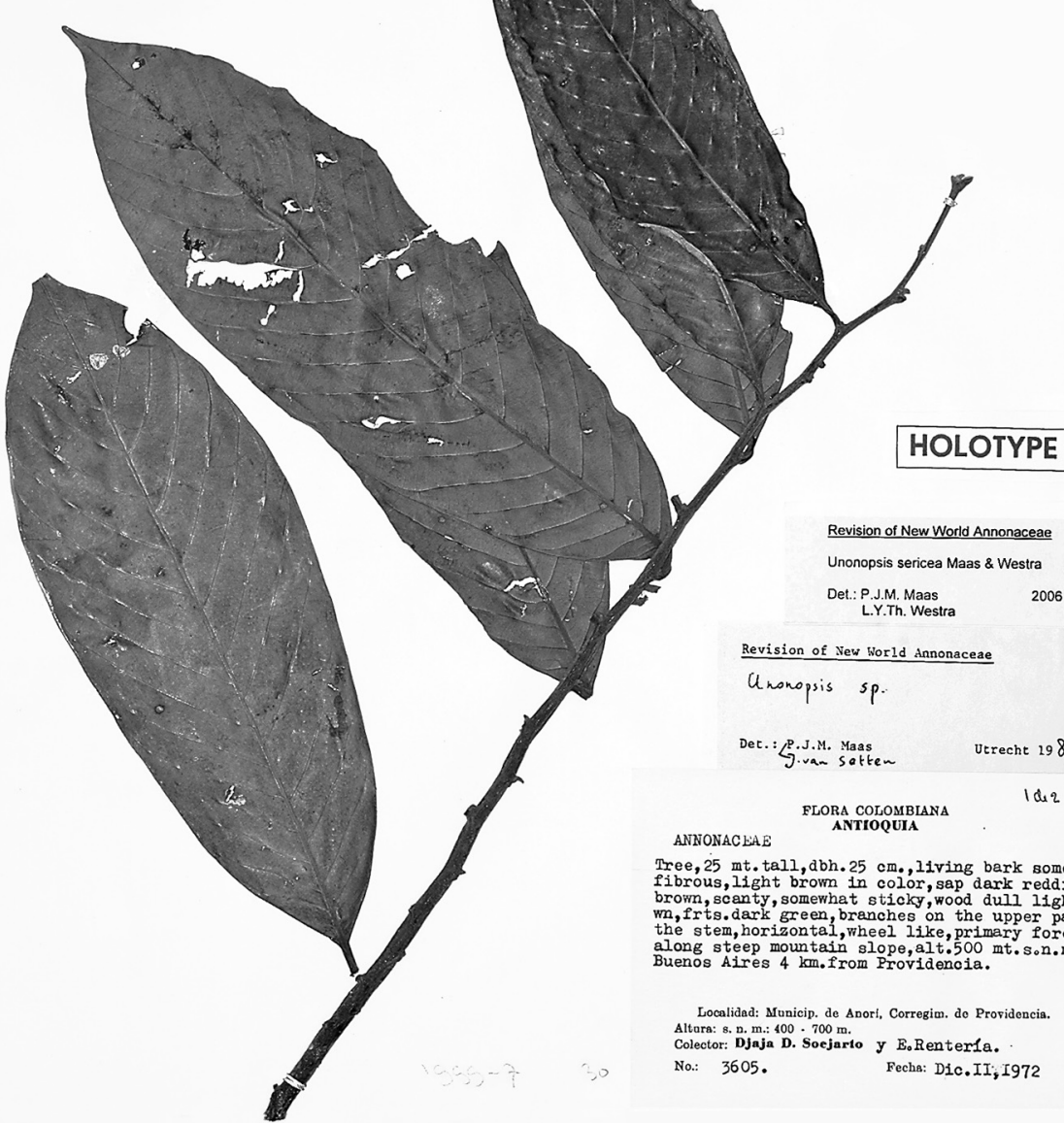

Fig. 32. Unonopsis sericea Maas \& Westra. Fruiting twig (Soejarto \& Rentería A. 3605, holo HUA). 


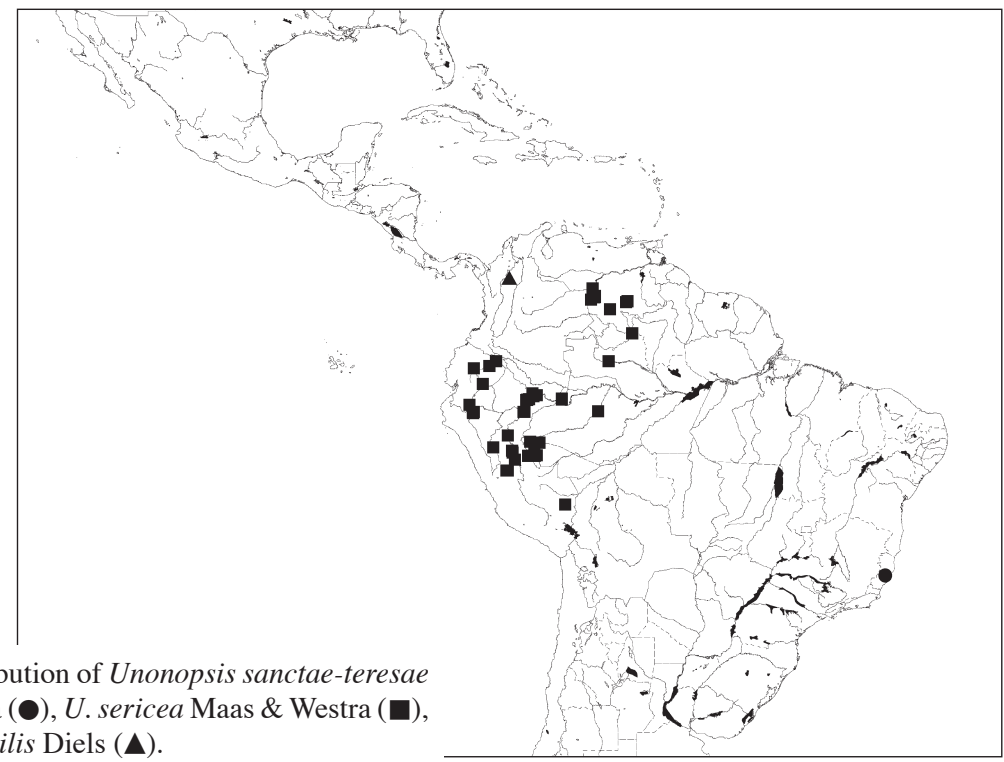

Map 18. Distribution of Unonopsis sanctae-teresae Maas \& Westra (○), U. sericea Maas \& Westra (ם), and $U$. spectabilis Diels $(\mathbf{\Delta})$.

10-11 by $11-13 \mathrm{~mm}$, sparsely covered with appressed hairs, soon glabrous, apex rounded, not apiculate, wall $0.3-0.5 \mathrm{~mm}$ thick, stipes $15-20$ by $1 \mathrm{~mm}$; fruiting receptacle depressed ovoid, 7-11 by $4-6 \mathrm{~mm}$, densely covered with appressed pale brownish white hairs. Seed 1 , lateral, c. 12 by 12 by $6 \mathrm{~mm}$, shiny brown.

Distribution - Colombia (Antioquia).

Habitat \& Ecology - In non-inundated, primary forest along steep mountain slope. At an elevation of c. 500 m. Flowering: unknown; fruiting: December. Only known from the type collection.

Note - Unonopsis sericea can be recognized by leaves with a dense cover of appressed pale brownish white hairs on the lower side. There are also hairy forms of U. guatterioides (Central Brazil, Bolivia), but with an indument consisting at least partly of erect hairs. Moreover, U. sericea has 1-seeded monocarps (vs 1-several-seeded in U. guatterioides) on longer stipes ( $\geq 15 \mathrm{vs} \leq 13 \mathrm{~mm}$ ).

40. Unonopsis sessilicarpa Maas \& Westra, spec. nov. - Fig. 33; Map 19

Unonopsi longipedi proxima sed monocarpiis subsessilibus vel breviter stipitatis et pedicellis brevioribus differt. - Typus: Cogollo \& Borja 1630 (holo COL; iso MO), Colombia, Antioquia, Mun. San Luis, cañon of Río Claro, 330-500 m, 1 May 1984.

Tree 6-16 m tall, 8-12 cm diam.; young twigs densely covered with a velutinous indument of appressed to erect, long-persistent, pale brown hairs 1-1.5 mm long. Leaves: petiole 3-6 mm long, 2-4 mm diam.; lamina generally narrowly elliptic to narrowly obovate, symmetrical, rarely slightly asymmetrical, $15-31$ by $6.5-12 \mathrm{~cm}$ (leaf index $2.3-3.5$ ), chartaceous, rather densely verruculose, dull above, greyish green to pale brown on both sides, primary vein densely covered with erect and appressed hairs above, otherwise subglabrous except for some hairs along secondary veins, densely 


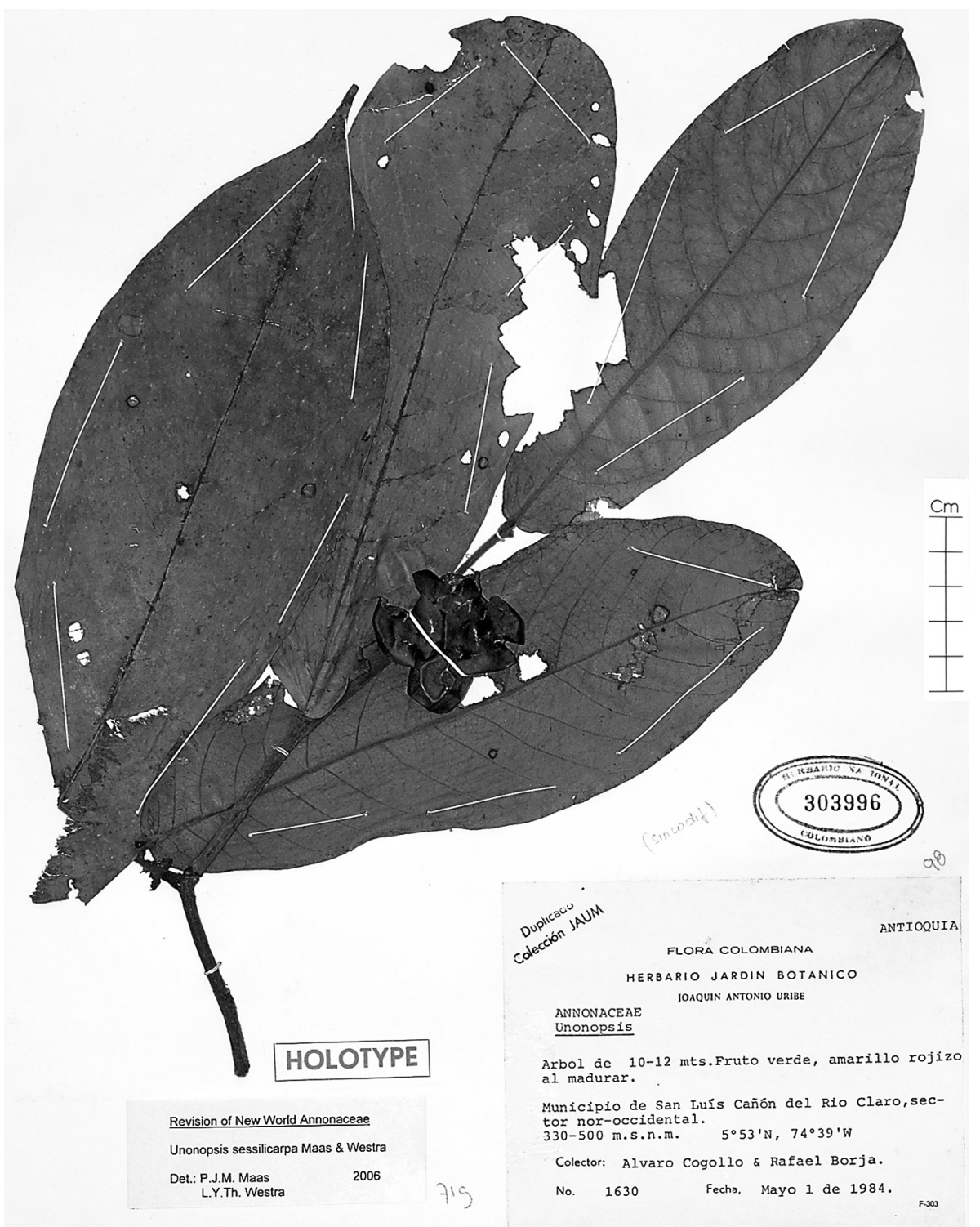

Fig. 33. Unonopsis sessilicarpa Maas \& Westra. Fruiting twig (Cogollo \& Borja 1630, holo COL).

covered with erect and appressed hairs below, base cordate to obtuse, apex acuminate (acumen 5-15 mm long), secondary veins distinct, curved, 12-16 on either side of primary vein, slightly impressed above, angles with primary vein $45-55^{\circ}$, loop-forming at right to obtuse angles, smallest distance between loops and margin 1-3 mm, tertiary veins distinct, percurrent. Inflorescences among leaves or on older branches, compact, composed of 1 or 2 rhipidia, mostly sessile, axial internodes $<1-2 \mathrm{~mm}$ long; rhipidia 1- or 2-flowered, to sometimes c. 8 flowers in succession, sympodial rachis to $8 \mathrm{~mm}$ 
long; upper bract at c. 1/6 from the base of the pedicel, depressed to broadly ovate, 2-3 mm long, outer side densely covered with appressed hairs; pedicels $4-5 \mathrm{~mm}$ long, c. $2 \mathrm{~mm}$ diam., fruiting pedicels 5-20 $\mathrm{mm}$ long, to $5 \mathrm{~mm}$ diam., densely covered with appressed and erect hairs; flower buds globose; sepals free, shallowly ovate-triangular, 2-3 by $3-4 \mathrm{~mm}$, outer side densely covered with appressed hairs; petals yellow or 'café claro' in vivo, outer ones broadly ovate, slightly concave, $8-9$ by $7-8 \mathrm{~mm}$, outer side densely covered with appressed hairs, inner ones broadly ovate, strongly concave, $9-10$ by $7 \mathrm{~mm}$, glabrous except for hairy exposed part; stamens $1.5-2 \mathrm{~mm}$ long, connective shield glabrous; carpels 30-50, c. $2 \mathrm{~mm}$ long, densely covered with appressed and erect hairs, ovules not yet studied. Monocarps 6-12, green, maturing yellow to finally red in vivo, brownish in sicco, globose to ellipsoid, 13-25 by 13-20 $\mathrm{mm}$, densely to sparsely covered with appressed and erect hairs, apex rounded, not apiculate, wall $0.2-0.3 \mathrm{~mm}$ thick, stipes $2-3$ by $2-3 \mathrm{~mm}$; fruiting receptacle broadly to depressed ovoid, 3-6 by $3-10 \mathrm{~mm}$, densely covered with appressed hairs. Seeds $1-3$, lateral, $11-13$ by $7-11$ by $5-6 \mathrm{~mm}$, brown.

Distribution - Colombia (Antioquia, Caldas, and (?) El Valle).

Habitat \& Ecology - In non-inundated forest. At elevations of 60-1200 m. Flowering: March, August, November; fruiting: January to May, July, August, October, November.

Notes - Unonopsis sessilicarpa looks somewhat like U. longipes, but it is readily distinguished by shortly stipitate to almost sessile monocarps (vs stipes $\geq 6 \mathrm{~mm}$ long); it also differs by the somewhat larger monocarps on average (13-25 vs $15-17 \mathrm{~mm}$ ) and the generally shorter pedicels (4-20 vs $15-50 \mathrm{~mm}$ long).

There are two collections from El Valle, both sterile (marked with an asterisk), which may also belong to this species.

Selection of other specimens (14) examined:

Colombia. Antioquia: Mun. Tarazá, Corregimiento El 12, road to Barroblanco, $1 \mathrm{~km}$ E of Barroblanco, Quebrada Puquí, Finca Corrales, 280 m, Callejas et al. 5486 (HUA); Hwy. MedellínBogotá, 2 km from Río Claro towards Río Samaná, 790 m, Cogollo \& Brand 375 (MO); Mun. Cáceres, Vereda Cacerí, km 43 of road from Cáceres to Zaragoza, 560 m, Giraldo G. \& Zea J. 35 (HUA); Mun. San Luis, Quebrada La Cristalina, 550-690 m, J.G. Ramírez \& Cárdenas L. 485, 773 (COL, MO). Caldas: Mun. Norcasia, Proyecto hidroeléctrico 'La Miel', 400-600 m, W.G. Vargas 6370 (HUA). El Valle: Mun. Buenaventura, Corregimiento San Cipriano, Reserva Natural de Escalerete, 100 m, Devia et al. 3796 (COL)*; Buenaventura, Mun. Bajo Anchicajá, 300 m, Gentry et al. $68430(\mathrm{COL})^{*}$.

\section{Unonopsis silvatica R.E. Fr. - Map 19}

Unonopsis silvatica R.E. Fr. (1956) 434, t. 2. - Type: Philipson et al. 2209 (holo S; iso BM, US), Colombia, Meta, Sierra de la Macarena, Central Mts., Entrada Ridge, 800 m, 24 January 1950.

Tree c. $8 \mathrm{~m}$ tall; young twigs sparsely covered with appressed long hairs, soon glabrous. Leaves: petiole 3-4 mm long, $2 \mathrm{~mm}$ diam.; lamina narrowly elliptic, slightly asymmetrical, $15-30$ by $6-10 \mathrm{~cm}$ (leaf index $2.5-4$ ), chartaceous, not verruculose, dull above, pale greyish above, pale greyish green below, glabrous above, sparsely covered with some appressed hairs along primary vein below, base obtuse, apex acuminate (acumen c. $10 \mathrm{~mm}$ long), secondary veins distinct, curved, 11-14 on either side of primary vein, impressed above, angles with primary vein $50-60^{\circ}$, loop-forming at 


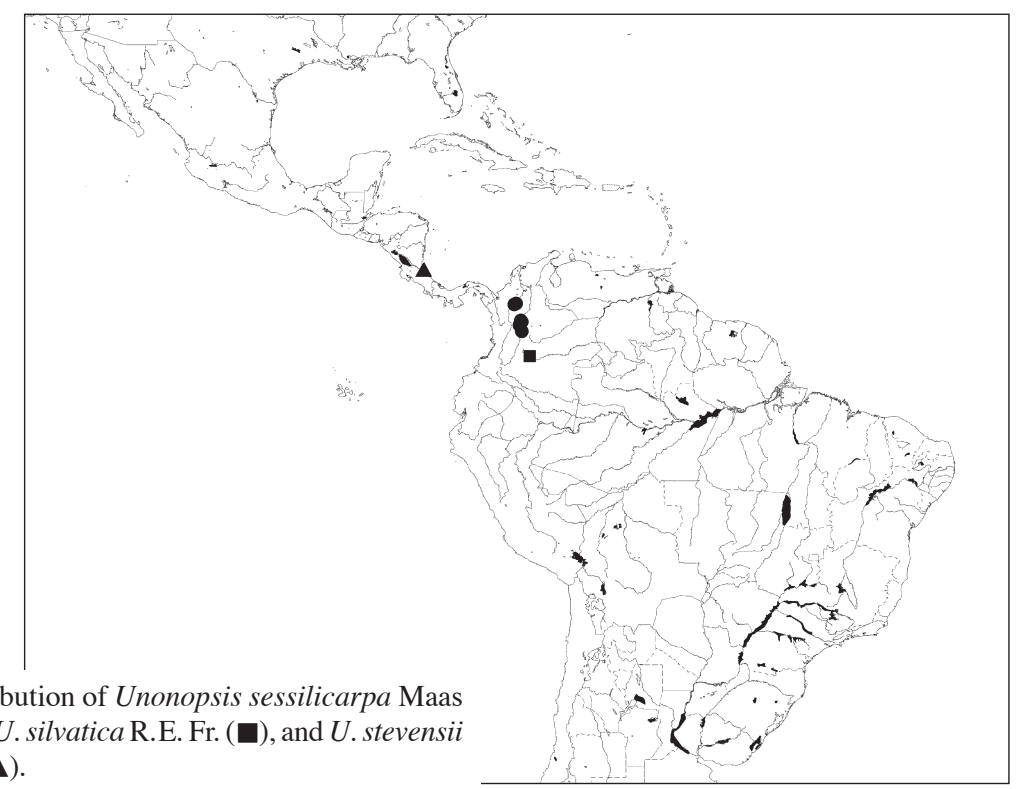

Map 19. Distribution of Unonopsis sessilicarpa Maas \& Westra $(\bullet)$, U. silvatica R.E. Fr. (ם), and U. stevensii G.E. Schatz (山).

obtuse angles, smallest distance between loops and margin 2-3 $\mathrm{mm}$, tertiary veins distinct, percurrent. Inflorescences (as far as seen) among leaves, compact, showing a single fruit from rhipidium with up to c. 4 flowers in succession; upper bract at 1/5 from the base of the pedicel, broadly ovate-triangular, c. $1 \mathrm{~mm}$ long, outer side densely covered with appressed hairs; fruiting pedicels 40-45 $\mathrm{mm}$ long, $2 \mathrm{~mm}$ diam., rather densely covered with appressed hairs; flower buds not seen; sepals free, shallowly ovate-triangular, c. 2 by $3 \mathrm{~mm}$, outer side densely covered with appressed hairs; petals, stamens, and carpels unknown. Monocarps 8-10, green in vivo, black in sicco, globose, 16-17 mm diam., sparsely covered with appressed hairs, soon glabrous, apex rounded, not apiculate, wall $0.2-0.3 \mathrm{~mm}$ thick, stipes $7-8$ by $2 \mathrm{~mm}$. Seed 1 , apical, $13-14$ by 10 by $7 \mathrm{~mm}$, pale brown.

Distribution - Colombia (Meta).

Habitat \& Ecology - In forest. At an elevation of c. 800 m. Flowering: unknown; fruiting: January. Only known from the type collection.

Note - The only collection of $U$. silvatica is too incomplete to allow any conclusions about its affinities.

\section{Unonopsis spectabilis Diels - Map 18}

Unonopsis spectabilis Diels (1905) 131. - Type: Ule 5795 (holo B; iso G, K, L, MG; fragments F, S), Brazil, Acre, Rio Juruá-Mirim, 1 September 1901.

Unonopsis velutina Maas, in Maas et al. (1986) 275, f. 11e, f, 19, syn. nov. - Type: Guánchez 380 (holo U, 2 sheets), Venezuela, Amazonas, Dep. Atures, $5 \mathrm{~km} \mathrm{~N}$ of San Pedro de Cataniapo, 60 km SE of Puerto Ayacucho, 120-150 m, 9 November 1980.

Tree or rarely a shrub 3-25 m tall, 3-30 (-80) cm diam., bark often with red exudate; young twigs densely covered with a velutinous indument of erect, brownish, long- 
persistent hairs. Leaves: petiole $6-15 \mathrm{~mm}$ long, $2-5 \mathrm{~mm}$ diam.; lamina generally narrowly elliptic to narrowly obovate, $15-45$ by $6-18 \mathrm{~cm}$ (leaf index $2.1-3.5$ ), chartaceous, not or sparsely verruculose, slightly shiny above, pale brown, green, or greyish green on both sides, glabrous, but primary and secondary vein often densely covered with erect, brown hairs above, densely covered with erect hairs below, less often sparsely hairy to subglabrous, base acute to obtuse, apex acuminate (acumen 1-15 mm long), secondary veins distinct, curved, $8-15$ on either side of primary vein, impressed above, angles with primary vein $45-65^{\circ}$, loop-forming at right to obtuse angles, smallest distance between loops and margin 1-2 mm, tertiary veins distinct, percurrent. Inflorescences on older branches, less often among leaves, compact or sometimes sublax, composed of $2-$ c. 6 rhipidia, in fruiting stage often a single rhipidium remaining, axial internodes $<1-3(-10) \mathrm{mm}$ long; rhipidia 2- or 3-flowered, to occasionally c. 15 flowers in succession; sympodial rachis inconspicuous to rarely c. $22 \mathrm{~mm}$ long, incidentally with internodes to 3(-5) $\mathrm{mm}$ long, free pedicel remnants incidentally present, to 5(-8) $\mathrm{mm}$ long; upper bract at 1/2-3/4 from the base of the pedicel, very broadly ovate, 3-6 mm long, outer side densely covered with appressed hairs; pedicels 10-25 mm long, 1-2 $\mathrm{mm}$ diam., fruiting pedicels to $35 \mathrm{~mm}$ long, 3-5 mm diam., densely covered with appressed hairs; flower buds subglobose; sepals initially forming a cup-shaped structure of up to $15 \mathrm{~mm}$ diam., later free for most of their length, ovate, very broadly ovate, or depressed ovate, $3-7$ by $5-10 \mathrm{~mm}$, outer side densely covered with appressed hairs; petals yellow to cream in vivo, outer ones broadly to very broadly ovate, concave, 9-12 by $8-10\{-12\} \mathrm{mm}$, outer side densely covered with appressed silvery white hairs, inner ones broadly ovate, concave, $7-8\{-10\}$ by $6-10 \mathrm{~mm}$, glabrous except for hairy exposed part; stamens 2-4 mm long, connective shield papillate; carpels 10-25, 1-5 mm long, densely covered with appressed whitish hairs, ovules 2 or 3, lateral. Monocarps 2-25, (glaucous) green, maturing yellow to orange in vivo, brown to black in sicco, globose to ellipsoid, $15-35$ by $15-25 \mathrm{~mm}$, densely to finally sparsely covered with erect hairs, apex rounded, not apiculate, wall $0.5-1\{-2\}$ mm thick, stipes $0-10\{-15\}$ by $2.5-5$ $\mathrm{mm}$; fruiting receptacle depressed ovoid, 6-10 by $10-15 \mathrm{~mm}$, densely covered with erect hairs. Seeds $1-4$, lateral, $9-13$ by $9-12$ by $5-9 \mathrm{~mm}$, reddish brown.

Distribution - Amazonian Venezuela (Amazonas), Colombia, Ecuador, Peru, Brazil (Acre, Amazonas).

Habitat \& Ecology - In non-inundated forest, often on clayey, red soil. At elevations of 100-1000 m. Flowering and fruiting: throughout the year.

Vernacular names - Brazil: Envira cheirosa folha grande. Colombia: Espintana. Ecuador: Aiconatio (Secoya), Yeitz. Peru: Auca hicoja, Cacahuillo, Espintana, Hicoya, Icoja negra. Venezuela: Kunjuasta (Yekuana), Tanoajua (Piaroa).

Uses - Bark infusion is used against rheumatism; bark is sold in Pucallpa, Peru at the market as 'Icoja negra' (Maas et al. 6229).

Notes - Unonopsis spectabilis is quite characteristic by leafy twigs which are covered with a velutinous indument of long-persistent, erect brown hairs, by the long, initially completely fused sepals, and by shortly stipitate, several-seeded and thickwalled monocarps.

The inflorescences in some collections (e.g. Guánchez 85, Marin 1753, Pipoly et al. 12553) are noteworthy because of the articulation positioned well above the basal pedicel bract, ultimately resulting in a free pedicel remnant to $0.5 \mathrm{~cm}$ (or more). 


\section{Unonopsis stevensii G.E. Schatz - Map 19}

Unonopsis stevensii G.E. Schatz (1998) 439, f. 3. - Type: Stevens et al. 24716 (holo MO, 2 sheets; iso CR, F, HNMN, INB, K, MEXU, MO, OWU, PMA, U, UNAM, US, WIS), Costa Rica, Limón, Cerro Coronel, E of Río Zapote, from E of new road to Raphia swamp, within $1 \mathrm{~km}$ of Río Colorado, 10-40 m, 12 March 1987.

Tree 2-12 m tall; young twigs glaucous, glabrous. Leaves: petiole 2-4 mm long, 1-2 mm diam., initially glaucous; lamina narrowly oblong-elliptic, slightly falcate, 17-25 by 3-6 cm (leaf index 4-6.3), chartaceous, not or sparsely verruculose along primary vein, greyish green above, brownish green to greyish green below, glabrous on both sides, base cordate to obtuse, apex long-acuminate (acumen 10-20 mm long), secondary veins distinct, curved, 13-18 on either side of primary vein, slightly raised above, angles with primary vein $65-70^{\circ}$, loop-forming at right to obtuse angles, smallest distance between loops and margin $2-5 \mathrm{~mm}$, tertiary veins indistinct, not percurrent. Inflorescences among leaves or on older branches, or also borne from the trunk, lax to compact, composed of 1-4 rhipidia; axial internodes < 1-2 mm long; rhipidia 1- or 2-flowered, to 6 flowers in succession, sympodial rachis to $5 \mathrm{~mm}$ long; upper bract at $1 / 4-1 / 3$ from the base of the pedicel, ovate-triangular, $<1 \mathrm{~mm}$ long, outer side rather densely covered with appressed brown hairs; pedicels 7-12 mm long, c. $1 \mathrm{~mm}$ diam., fruiting pedicels to $18 \mathrm{~mm}$ long, rather densely covered with appressed brown hairs; flower buds subglobose; sepals basally connate, deltate, 1-2 by 1-2 mm, outer side densely covered with appressed brown hairs; petals yellow in vivo, outer ones broadly ovate, slightly concave, $3-5$ by $3-4 \mathrm{~mm}$, outer side densely covered with appressed brown hairs, inner ones broadly ovate to ovate, strongly concave, $3-5$ by $2-4 \mathrm{~mm}$, outer side glabrous except for hairy exposed part; stamens c. $1 \mathrm{~mm}$ long, connective shield glabrous; carpels 3-7, 1-1.5 mm long, densely covered with appressed brown hairs, ovules ( 1 or) 2 , position not yet studied. Monocarps 5-8, glaucous, green to orange-red in vivo, brownish in sicco, subglobose, 12-18 mm diam., glabrous, apex rounded, not apiculate, wall $0.2-0.3 \mathrm{~mm}$ thick, stipes $9-14$ by $1 \mathrm{~mm}$; fruiting receptacle depressed ovoid, 1-2 by 2-3 mm, rather densely covered with appressed brown hairs. Seed 1 , position not yet studied, $10-12$ by $7-9$ by $4-6 \mathrm{~mm}$, pale brown.

Distribution - Costa Rica (Limón).

Habitat \& Ecology - In non-inundated, wet, evergreen forest. At elevations of 0-170 m. Flowering and fruiting: January, March, April, September.

Note - Unonopsis stevensii is unique by the very narrow, slightly falcate leaves with a cordate to obtuse leaf base, the very tiny, yellow petals, and the glaucous young twigs and monocarps.

44. Unonopsis stipitata Diels - Plate 2c, d, 6a, d; Map 20

Unonopsis stipitata Diels (1905) 130; R.E. Fr. (1937) 260, f. 6a-e. - Type: Ule 6191 (holo B; iso F, G, HBG, IAN, K, L, MG), Peru, Loreto, near the Colombian city of Leticia, June 1902.

Unonopsis oblanceolata R.E. Fr. (1957a) 604, syn. nov. - Type: Schultes \& López. 10064 (holo US),

Colombia, Guainía, basin of Río Guainía, Río Naquiení, vicinity of Cerro Monachí, June 1948.

Unonopsis rigida R.E. Fr. (1957b) 329, syn. nov. - Type: Fróes 21110 (holo NY; iso K, US), Brazil, Amazonas, Rio Negro, Porto Curucuhy, 6 October 1945.

Tree or shrub 1-12 m tall, 1-10(-15) cm diam.; young twigs densely covered with appressed and erect brown hairs, soon glabrous. Leaves: petiole (3-)4-10(-15) mm 
long, (1-)2-4(-5) mm diam.; lamina narrowly obovate, sometimes obovate or narrowly elliptic, 10-30(-44) by 4-11(-13) cm (leaf index 2.1-3.9(-5)), coriaceous, sometimes chartaceous, not or mostly sparsely verruculose, shiny above, greyish green above, brown to greyish brown below, glabrous to sparsely covered with appressed hairs along primary and secondary veins on both sides, base acute to obtuse, apex acuminate (acumen 5-35(-60) mm long), secondary veins distinct, curved, 10-20(-24) on either side of primary vein, raised above, angles with primary vein $45-70^{\circ}$, loop-forming at right to obtuse angles, smallest distance between loops and margin 2-4 mm, tertiary veins distinct, percurrent. Inflorescences on older branches, rarely among leaves, or borne from the trunk, usually compact, composed of 1-4(-6) rhipidia; peduncle-like base $0-3(-5) \mathrm{mm}$ long; axial internodes $<1(-2) \mathrm{mm}$ long; rhipidia 1-3-flowered, to 12 flowers in succession; sympodial rachis to $8 \mathrm{~mm}$ long, with free pedicel remnants $0-1(-2) \mathrm{mm}$ long; upper bract at $1 / 5-2 / 3$ from the base of the pedicel, broadly to very broadly ovate, 1-2 mm long, outer side rather densely to densely covered with appressed and erect brown hairs; pedicels 10-40 $\mathrm{mm}$ long, 1-2 mm diam., fruiting pedicels to $50(-70) \mathrm{mm}$ long, to $5 \mathrm{~mm}$ diam., rather densely to densely covered with appressed and erect brown hairs; flower buds very broadly to depressed ovoid; sepals free to basally connate, very broadly to shallowly ovate-triangular, $1-2.5$ by $1-3.5$ $\mathrm{mm}$, outer side rather densely to densely covered with appressed and erect brown hairs; petals cream to yellow in vivo, outer ones broadly depressed to very broadly ovate, concave, $4-10$ by $5-14 \mathrm{~mm}$, outer side rather densely covered with appressed and erect brown hairs, inner ones very broadly to depressed ovate, strongly concave, 3-8 by $5-16 \mathrm{~mm}$, outer side glabrous except for hairy exposed part; stamens $1-2 \mathrm{~mm}$ long, connective shield densely to sparsely papillate; carpels 30-100, 1-2 mm long, densely covered with appressed brown hairs, ovule 1, basal. Monocarps 10-60, green, maturing

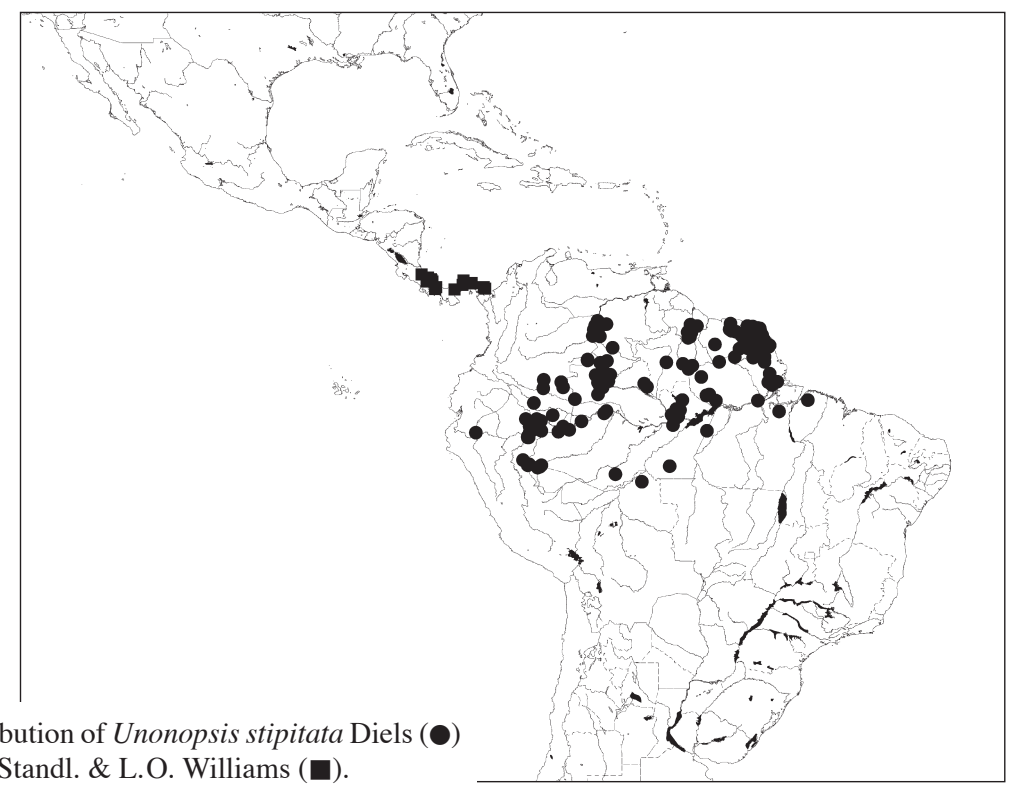

Map 20. Distribution of Unonopsis stipitata Diels ( and U. storkii Standl. \& L.O. Williams 
orange in vivo, reddish brown in sicco, ellipsoid to broadly so, 10-20 by 5-15 mm, rather densely to sparsely covered with appressed hairs, soon glabrous, apex rounded, asymmetrically apiculate (apiculum $0.1-0.7 \mathrm{~mm}$ long), wall $0.2-0.5\{-1.5\} \mathrm{mm}$ thick, stipes $5-25$ by $0.5-2 \mathrm{~mm}$; fruiting receptacle depressed ovoid to subglobose, $6-15$ by $8-20 \mathrm{~mm}$, densely covered with appressed brown hairs. Seed 1, basal, 9-15 by 7-11 by $5-8 \mathrm{~mm}$, reddish brown.

Distribution - Throughout the Amazon Region of Colombia, Venezuela, Brazil, and Peru, and in the 3 Guianas.

Habitat \& Ecology - In non-inundated forest, mostly on clayey to sandy soil. At elevations up to $600 \mathrm{~m}$. Flowering and fruiting: throughout the year.

Vernacular names - Brazil: Envira cascuda, Envira preta, Envira surucucú, Envireira, Pindaíba, Pindaíba preta. Colombia: Carguero, Choo-ree (Puinave), Gururei (Huitoto), Hö-rö’-rai (Huitoto), Icïbono-fiiquicï (Muinane), Jïrïda (Huitoto), Jïrirai (Huitoto), Jïrurai (Huitoto), Jirirai (Huitoto), Mee-see-mo-hoó (Barasana), Vara de pescar, Yisiko (Muinane). French Guiana: A teiki uma udu (Boni, Creole), Femelle mama yawé (Creole), Kuukumwi priye (Palikur), Mahot rouge (Creole), Mama yawé (Creole), Okaypu (Wayana), Pakirem priye (Palikur), Pilasiay (Mupea), Pina’ï(Wayãpi), Pina'ïtay (Wayãpi), Pina'ïtowu (Wayãpi). Guyana: Rough bark arara. Peru: Bara caspi, Carahuasca, Espintana, Espintana negro, Tortuga caspi, Yaú. Suriname: Pepre soitu (Sranang), Pepre nanga sowtu (Paramaccan), Pikapika (Sranang), Yariyari (Arawak). Venezuela: Cililicuato (Guahiba), Majagua, Majagua blanca, Majagua candelero, Majagua de tierra firme, Majagua negra, Majaguillo, Palo anavelo (Piaroa).

Uses - The Puinave, of the northwest Amazon, apply pulverized leaves against senile dementia (Schultes, 1993). See also notes on uses under U. veneficiorum.

Notes - Unonopsis stipitata, one of the most common species in the genus, is easily recognized by its leaves and monocarps. The leaves are often narrowly obovate, a feature not too often seen in the genus; the upper side of the lamina is mostly shiny and the secondary veins are strongly raised (in most species they are impressed). The fruits, mostly produced from the main trunk, are orange, 1-seeded, and mostly ellipsoid in shape, which is rarely encountered in Unonopsis. Another typical feature is the strongly flattened flower buds.

Clark 7270 (NY, U, VEN) from San Carlos de Río Negro, Amazonas, Venezuela is an unusually large tree for this species, namely $17 \mathrm{~m}$ tall by $29 \mathrm{~cm}$ !

A few collections from French Guiana, e.g. Feuillet et al. 10095, Sabatier et al. 4611, tend to have more lush inflorescences, with a larger number of flowers appearing at the same time than is average for this species.

\section{Unonopsis storkii Standl. \& L.O. Williams - Plate 2e, 6b, c; Map 20}

Unonopsis storkii Standl. \& L.O. Williams in Williams (1963) 546. - Type: Stork 4608 (holo UC; iso EAP, F n.v.), Costa Rica, Limón, 6 miles upstream from mouth of Río Estrella, 19 April 1952.

Tree or sometimes a shrub 3-10 m tall, 5-15 cm diam.; young twigs densely covered with erect, curly, brown hairs, soon glabrous. Leaves: petiole 5-10 mm long, 3-5 mm diam.; lamina narrowly elliptic to narrowly obovate, $30-47$ by $9-19 \mathrm{~cm}$ (leaf index 2.5-3.6), chartaceous, densely verruculose, dull above, greyish green to brown above, pale brown to brownish green below, sparsely covered with erect, curly hairs along 
primary vein to glabrous above, sparsely covered with erect and appressed hairs to glabrous below, base cordate, sometimes obtuse, apex acuminate (acumen 10-25 mm long), secondary veins distinct, curved, 17-20 on either side of primary vein, impressed above, angles with primary vein $45-55(-70)^{\circ}$, loop-forming at right to obtuse angles, smallest distance between loops and margin 1-2 mm, tertiary veins distinct, percurrent. Inflorescences among leaves or (at least in fruit) on older branches, compact or less often sublax, composed of 1-3 rhipidia; peduncle-like base $0-8 \mathrm{~mm}$ long; axial internodes $\leq 1-4 \mathrm{~mm}$ long; rhipidia 1-3-flowered, to c. 5 flowers in succession, sympodial rachis to $3 \mathrm{~mm}$ long; upper bract at 1/2-1/4 from the base of the pedicel, broadly ovate-triangular, 2-3 mm long, outer side densely covered with appressed brown hairs; pedicels 10-20 $\mathrm{mm}$ long, c. $1 \mathrm{~mm}$ diam., fruiting pedicels to $30(-50) \mathrm{mm}$ long, to 4 mm diam., densely to rather densely covered with appressed brown hairs; flower buds depressed ovoid; sepals basally connate, shallowly ovate-triangular, $1.5-3$ by $2-4\{-5\}$ $\mathrm{mm}$, outer side densely covered with appressed brown hairs; petals cream to white in vivo, outer ones broadly ovate-triangular, slightly concave, $7-11\{-12\}$ by $7-8\{-11\}$ $\mathrm{mm}$, outer side densely covered with appressed brown hairs, inner ones broadly ovate, strongly concave, $6-8$ by $5-6\{-8\} \mathrm{mm}$, outer side glabrous except for hairy exposed part; stamens 1.5-2 mm long, connective shield glabrous; carpels 40-50, 1-1.5 mm long, densely covered with appressed hairs, ovules 3-6, lateral. Monocarps 10-25, green, maturing orange to finally red in vivo, dark brown in sicco, ellipsoid to globose, $10-23$ by $10-12\{-16\} \mathrm{mm}$, densely to sparsely covered with appressed hairs, apex rounded, hardly apiculate, wall $0.2-0.3\{-3\} \mathrm{mm}$ thick, stipes $5-20(-25)$ by $1-1.5$ $\mathrm{mm}$; fruiting receptacle depressed ovoid, $3-7$ by $6-12 \mathrm{~mm}$, densely covered with erect, curly, brown hairs. Seeds $1-6$, lateral, $9-11$ by $9-11$ by $2-5 \mathrm{~mm}$, brown.

Distribution - Costa Rica (Limón) and Panama.

Habitat \& Ecology - In forest, sometimes riparian or swampy. At elevations of 0-500 m. Flowering: February, March, May to July; fruiting: January to April, June, July, and from October to December.

Note - Unonopsis storkii is close to the Costarican U. theobromifolia. For further details see under the latter.

\section{Unonopsis theobromifolia N. Zamora \& Poveda - Map 21}

Unonopsis theobromifolia N. Zamora \& Poveda (1988) 399, f. opposite p. 400. - Type: Zamora et al. 1327 (holo CR; iso F, MEXU, MO, NY), Costa Rica, San José, Zona Protectora La Cangreja, Santa Rosa de Puriscal, 400 m, 14 May 1987.

Tree or shrub 2-15 m tall, 4-13 cm diam.; young twigs rather densely covered with erect brown hairs, soon glabrous. Leaves: petiole 5-10 mm long, 2-3 mm diam.; lamina generally narrowly elliptic to narrowly obovate, $20-45$ by $7-14 \mathrm{~cm}$ (leaf index 2.2-3.7), chartaceous, somewhat bullate, densely verruculose, dull above, greyish green above, pale green to pale brown below, rather densely covered with erect hairs along primary vein above, rest subglabrous, densely to rather densely covered with erect hairs below, base cordate, apex acuminate (acumen 5-40 $\mathrm{mm}$ long), secondary veins distinct, curved, 12-18 on either side of primary vein, impressed above, angles with primary vein $40-45^{\circ}$, loop-forming at right to obtuse angles, smallest distance between loops and margin 1-2 mm, tertiary veins distinct, percurrent. Inflorescences 
among leaves or (particularly in fruit) on older branches, mostly showing a single flower/fruit on axis 3-6 mm long, but actually compact, composed of 1 or 2 rhipidia; rhipidia 1- or 2-flowered, to sometimes 5 flowers in succession; sympodial rachis to $3 \mathrm{~mm}$ long; upper bract at 1/4-1/3 from the base of the pedicel, broadly ovate-triangular, 2-4 mm long, outer side densely covered with appressed brown hairs; pedicels $3-5 \mathrm{~mm}$ long, c. $1 \mathrm{~mm}$ diam., fruiting pedicels to $10 \mathrm{~mm}$ long, to $3 \mathrm{~mm}$ diam., densely covered with appressed and erect brown hairs; flower buds very broadly ovoid to subglobose; sepals basally connate, shallowly triangular, $3-4$ by $3-4 \mathrm{~mm}$, outer side densely covered with appressed, brown hairs; petals cream to white in vivo, outer ones ovate to broadly so, flat, $6-8$ by $5-7 \mathrm{~mm}$, outer side densely covered with appressed hairs, inner ones broadly ovate, concave, $4-6$ by $4-5 \mathrm{~mm}$, outer side glabrous except for hairy exposed part; stamens 1-1.5 mm long, connective shield glabrous; carpels $<10,1-2$ mm long, densely covered with appressed hairs, ovules c. 5, lateral. Monocarps 5-9, green, maturing orange to finally red in vivo, brownish in sicco, ellipsoid to subglobose, $12-22$ by $12-18 \mathrm{~mm}$, densely covered with appressed and erect hairs when young, soon glabrous, apex rounded, not apiculate, wall $0.2\{-3\} \mathrm{mm}$ thick, stipes $2-4$ by $2-4$ $\mathrm{mm}$; fruiting receptacle subglobose, 3-7 $\mathrm{mm}$ diam., densely covered with appressed and erect brown hairs. Seeds $1-4$, lateral, $10-12$ by $8-10$ by $4-6 \mathrm{~mm}$, brown.

Distribution - Costa Rica (San José, Puntarenas).

Habitat \& Ecology - In forest, on lateritic to clayey soil. At elevations of 0-700 m. Flowering and fruiting: throughout the year.

Note - Unonopsis theobromifolia looks superficially similar to U. storkii, a species occurring in Costa Rica (Limón) and in Panama. It differs by shorter pedicels (3-10 vs $10-30(-50) \mathrm{mm})$, shorter stipes $(2-4$ vs $5-20(-25) \mathrm{mm})$, and a lower number of monocarps (5-9 vs 10-25). The lower side of the lamina in U. theobromifolia is densely to rather densely covered with erect hairs (while sparsely covered, with more curly hairs by comparison, to almost glabrous in U. storkii).

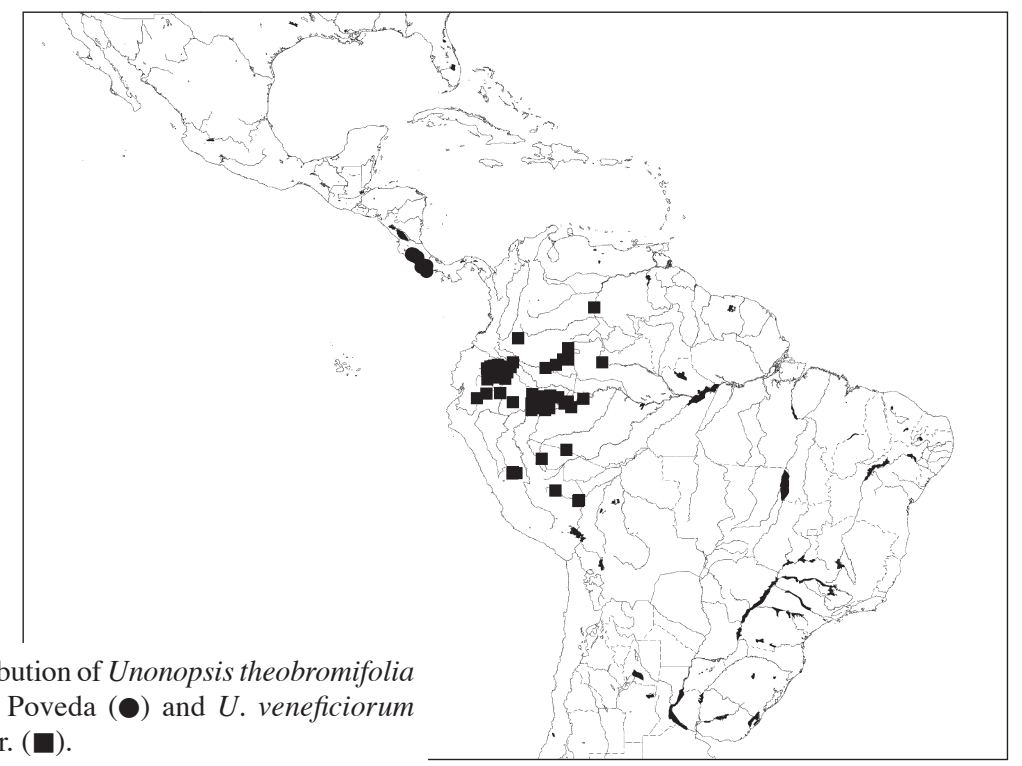

Map 21. Distribution of Unonopsis theobromifolia N. Zamora \& Poveda $(\bullet)$ and $U$. veneficiorum (Mart.) R.E. Fr. (ם) 


\section{Unonopsis veneficiorum (Mart.) R.E. Fr. - Map 21}

Unonopsis veneficiorum (Mart.) R.E. Fr. (1937) 259; Murillo-A. \& Restrepo (2000) 165. - Guatteria veneficiorum Mart. (1841) 34. - Type: Martius s.n. (holo M, 4 sheets), Brazil, Amazonas, Rio Japurá ('Habitat in sylvis Japurensibus, provinciae Rio Negro, ad veneficium Urari adhibetur'; another possible duplicate reads 'In silvis ad Indios Juri, ditionis Japurensis').

Tree or shrub 1-7(-15) $\mathrm{m}$ tall, $2-7(-12) \mathrm{cm}$ diam.; young twigs densely covered with erect and appressed brown hairs, soon glabrous. Leaves: petiole 5-7 mm long, 2-3(-4) mm diam.; lamina narrowly obovate, rarely narrowly elliptic, 17-30(-40) by $4-10(-18) \mathrm{cm}$ (leaf index (2.3-)3-4.2), chartaceous, densely verruculose, dull grey to sometimes greyish brown above, dull greyish green to brown below, sparsely covered with appressed hairs mainly along primary and secondary veins to glabrous on both sides, base obtuse to subcordate, rarely acute, apex long-acuminate (acumen 10-30 mm long), secondary veins distinct, curved, 11-14 on either side of primary vein, impressed above, angles with primary vein $40-50^{\circ}$, loop-forming at obtuse to sometimes right angles, smallest distance between loops and margin 2-4 mm, tertiary veins indistinct, percurrent. Inflorescences among leaves or on older branches, compact or sometimes (sub)lax or glomerulate, composed of (1-)3-10 rhipidia; peduncle-like base $0-4 \mathrm{~mm}$ long; axial internodes $<1-2(-4) \mathrm{mm}$ long; rhipidia 1-3(-4)-flowered, to $6(-15)$ flowers in succession; sympodial rachis to $5(-20) \mathrm{mm}$ long; upper bract at $(1 / 6-) 1 / 4-1 / 2$ from the base of the pedicel, broadly to depressed ovate, $1-1.5 \mathrm{~mm}$ long, outer side densely covered with appressed hairs; pedicels 5-15 mm long, 1-1.5 mm diam., fruiting pedicels 15-35 mm long, 1-3 mm diam., rather densely covered with appressed hairs; flower buds depressed to broadly ovoid; sepals basally connate, very broadly to shallowly ovate-triangular, $1.5-2$ by $2-3 \mathrm{~mm}$, outer side densely covered with appressed hairs; petals cream, white, to yellow in vivo, outer ones ovate to very broadly so, slightly concave, $4-10$ by $5-8 \mathrm{~mm}$, outer side densely covered with appressed hairs, inner ones ovate to broadly so, concave, $3-8$ by $3-6 \mathrm{~mm}$, outer side glabrous except for hairy exposed part; stamens 1.5-2 mm long, connective shield glabrous; carpels 5-15, 1.5-2.5 mm long, densely covered with appressed hairs, ovule 1, apical. Monocarps 5-30, green, yellow, orange, maturing red to black in vivo, brown in sicco, ellipsoid, $15-20(-22)$ by $10-15(-18) \mathrm{mm}$, surface distinctly shrivelled and rugulose in sicco, sparsely covered with appressed hairs, apex rounded, asymmetrically apiculate (apiculum $<0.1 \mathrm{~mm}$ long), wall $0.3-0.5\{-4\} \mathrm{mm}$ thick, stipes $10-20(-25)$ by $1-2 \mathrm{~mm}$; fruiting receptacle subglobose to depressed globose, 3-7 mm diam., densely covered with erect and appressed hairs. Seed 1, apical, 10-15 by $10-13$ by $7-10 \mathrm{~mm}$, brown.

Distribution - Throughout the Amazon Region of Colombia, Ecuador, Peru, and Brazil (Acre, Amazonas).

Habitat \& Ecology - Mostly in non-inundated forest, but in Colombia often in periodically inundated forest, on clayey to lateritic soil. At elevations up to $450 \mathrm{~m}$. Flowering and fruiting: throughout the year.

Vernacular names - Colombia: Choon (Puinave). Ecuador: Bara, Moncapatahue (Huaorani), Palo de anzuelo, Parro, Pï ha' ti, Rumicara caspi, Yana cara caspi. Peru: Bara caspi, Espintana, Icoja.

Uses - About 180 years ago Von Spix and Von Martius (Martius, 1831) reported the use of the astringent fruits of this species by the Jurí, Miraña, and other tribes in 
the upper Amazon Region in Brazil and Colombia as a component in the preparation of arrow poison ('Urari' = curare; the type label reads 'ad veneficium Urari adhibetur'). In Colombia this went as far upstream along the Río Caquetá as Araracuara. Later, Schultes reported use of roots as source of arrow poison by the Kofán, Ecuador, Colombia (Schultes, 1969), and use of roots and bark for the same purpose by the Barasana in the lower Apaporis basin, Colombia (Schultes, 1977, 1980; Schultes \& Raffauf, 1992: 252).

The Puinave, of the northwest Amazon, apply dried leaves against senile dementia. A similar use is made of leaves of U. stipitata (Schultes, 1993).

The mention of $U$. veneficiorum from Vaupés, Colombia, where it is reported to be used as a contraceptive by the Bora-Makú (Schultes, 1978, 1980), is based on a misidentification of the collection P. Silverwood-Cope 11 (ECON). This actually is Anaxagorea macrantha R.E. Fr. and it is the first record for Colombia of this rare species.

Notes - Unonopsis veneficiorum is recognizable by the long-acuminate and, in dried condition, dull greyish, densely verruculose leaves, and by its brownish, ellipsoid and distinctly shrivelled, 1-seeded monocarps.

Chatrou 218 (MO, U), from Explorama tourist camp, Quebrada Yanamono, Loreto, Peru has orange flowers, a colour only very rarely encountered in the genus (cf. $U$. aurantiaca).

Betancur \& Churchill 2180 (HUA) from Colombia, Caquetá, San Vicente de Caguán was collected at an exceptionally high elevation of $1250 \mathrm{~m}$ !

\section{INSUFFICIENTLY KNOWN SPECIES}

\section{Unonopsis umbilicata (Dunal) R.E. Fr.}

Unonopsis umbilicata (Dunal) R.E. Fr. (1937) 252. - Guatteria umbilicata Dunal (1817) 125, t. 33. - Type: Forsyth s.n. (holo G, 2 sheets), 'Granada'.

This species is only known from one incomplete collection, deposited in Geneva (G).

The herbarium collection consists of 3 leafy shoots and in a separate bag there is an infructescence with several loose seeds. According to the original drawing of Dunal (1817) the monocarps are transversely ellipsoid in shape, a very unusual feature in the genus Unonopsis and only seen so far in the Ecuadorian U. onychopetaloides.

The exact type locality is uncertain, the only indication being a note 'Granada' on one of the sheets. This has been interpreted tentatively by, among others, Fries as the Caribbean island Grenada (Fries, 1937: 252 - "Der Ursprung der Forsyth'schen Pflanze is nicht klar. Auf einer Etikette wird "Granada" angegeben, womit vielleicht die westindische, in der Nahe von St. Vincent gelegene Insel Grenada gemeint ist").

Howard (1988) mentioned that the type collection was attributed to 'Forsyth, Grenada'. According to him Forsyth never visited the West Indies, "but that he received specimens from Alexander Anderson who did visit Grenada and obtained plants for cultivation in the Botanic Garden on St. Vincent. However, no entry in Anderson's unpublished Hortus which we have consulted can be interpreted as this taxon." Howard (1988) assumes a possible origin from cultivated plants. 
The only certain record of Unonopsis in the Lesser Antilles is that of U. antillana, from St. Vincent. This was placed under synonymy of $U$. umbilicata by Howard, but is now placed by us (this paper) in synonymy with $U$. guatterioides.

In our opinion it is more probable that 'Granada' refers to New Granada, i.e. presentday Colombia.

\section{Unonopsis spec. A}

Tree 15-18 m tall; young twigs sparsely covered with appressed hairs, soon glabrous. Leaves: petiole 3-6 mm long, 1-2 mm diam.; lamina narrowly elliptic, 13-18 by 4-5 cm (leaf index 2.6-4.2), chartaceous, densely or not verruculose, dark brown on both sides, glabrous above, covered with some scattered hairs along primary vein and secondary veins below, otherwise glabrous, base acute, apex bluntly acute to bluntly acuminate (acumen to $5 \mathrm{~mm}$ long), secondary veins distinct, curved, 8-10 on either side of primary vein, slightly raised above, angles with primary vein $45-55^{\circ}$, loopforming at right angles, smallest distance between loops and margin 1-2 mm, tertiary veins indistinct, percurrent. Inflorescences together with leaves or on older branches, compact, only seen in fruiting stage, rhipidia (remnants) $1-3$, probably few-flowered; upper bract at $1 / 5$ from the base of the pedicel, broadly ovate-triangular, $1-1.5 \mathrm{~mm}$ long, outer side sparsely covered with appressed hairs; fruiting pedicels $20-25 \mathrm{~mm}$ long, c. $2 \mathrm{~mm}$ diam., sparsely covered with appressed hairs to glabrous; flower buds not seen; sepals free, shallowly ovate-triangular, $1.5-2$ by $4 \mathrm{~mm}$, outer side densely to sparsely covered with appressed hairs; petals, stamens, and carpels not seen. Monocarps 4-10, green in vivo, black in sicco, globose or obovoid (pear-shaped), 20-45 by $15-30 \mathrm{~mm}$, glabrous, apex rounded, not apiculate, wall $0.5-1 \mathrm{~mm}$ thick, stipes $3-5$ by $2-3 \mathrm{~mm}$. Seeds $1-3$, lateral, $15-17$ by $11-15$ by $6-12 \mathrm{~mm}$, brown to blackish.

Distribution - Colombia (Antioquia).

Habitat \& Ecology - In non-inundated forest. At an elevation of c. 800 m. Flowering: unknown; fruiting: February, November.

Note - This imperfectly known species, of which additional material is badly needed, is recognized by its large, thick-walled and sometimes pear-shaped monocarps.

Specimens examined:

Colombia. Antioquia: Mun. San Luis, Hwy. Medellín-Bogotá, Vereda La Josefina, road near 'El Pit 1', 800 m, 29 November 1983, Hoyos \& Hernández 509 (MO); Mun. San Luis, Hwy. Medellín-Bogotá, Vereda La Josefina, trail near Filo Estrecho and Santa Elena, 800 m, 21 February 1984, Hoyos \& Hernández 996 (MO).

\section{EXCLUDED SPECIES}

Unonopsis galeottiana (Baill.) R.E. Fr. (1900) 28. - Trigynaea galeottiana Baill. (1868b) 181. - Type: Liebmann 7 (lecto C (Maas et al., 1994)), Mexico. = Desmopsis trunciflora (Schltdl. \& Cham.) G.E. Schatz in Maas et al. (1994) 419.

Unonopsis leiophylla Diels (1931) 80. - Type: Spruce 2473 (holo B; iso C, E, G, GH, K, LE, NY, P, S, W), Brazil, Amazonas, Rio Vaupés ('Rio Vaupés, gapó [= igapó]', September 1852. $\equiv$ Pseudoxandra leiophylla (Diels) R.E. Fr. (1937) 226. 
Unonopsis polyphleba Diels (1905) 131. - Cremastosperma polyphlebum (Diels) R.E. Fr. (1931) 331. - Type: Ule 5628 (holo B n.v.; iso F, G, K, MG, S), Brazil, Acre, Rio Juruá-Mirim, August 1901. $\equiv$ Pseudoxandra polyphleba (Diels) R.E. Fr. (1937) 230.

Unonopsis trunciflora (Schltdl. \& Cham.) R.E. Fr. (1900) 27. - Xylopia trunciflora Schltdl. \& Cham. (1831) 417. - Type: Schiede \& Deppe 1287 (holo B), Mexico. $\equiv$ Desmopsis trunciflora (Schltdl. \& Cham.) G.E. Schatz, in Maas et al. (1994) 471.

\section{ACKNOWLEDGEMENTS}

We thank all curators of herbaria who made material available to us. We are indebted to Camilla Orava (Utrecht), who initially started the revision of Unonopsis, and who did much of the initial administrative and paperwork; that is, asking material on loan and setting up an electronical database. Rob van Aubel (Utrecht) gave us valuable assistance in completing the specimen administration and making a practical card system for daily usage. We are indebted to Hendrik Rypkema (Utrecht) who prepared the drawings for Fig. 1, Fig. 12, Fig. 13 and Fig. 19, to Heimo Rainer (WU) who prepared the distribution maps, and to Marc Matthies and Jorrit Schoen who made the photographs of herbarium material. We are also grateful to Roy Erkens (Utrecht) for his critical reading of the introductory section. Many thanks are due to Jifke Koek-Noorman (Utrecht) for her assistance with the chapter on leaf anatomy, particularly for her many suggestions and critically reading of the manuscript. Cris Hesse (Leiden) is acknowledged for his help in preparing the photomicrographs of leaf sections. We thank George Schatz (MO) for his cooperation in jointly describing several new species with us.

We are very grateful for all support we got from numerous persons in various respects, particularly assistance in the field: Rafael Aizprúa, Lars Chatrou, Roy Erkens, Domingos Folli, Renato Moraes de Jesus, Leo Junikka, Ludovic Kollmann, Hiltje Maas-van de Kamer, Michael Pirie, José Ribeiro, Antonio Webber, Tom Wendt, Nelson Zamora.

\section{REFERENCES}

Baillon, H. 1868a. Histoire des Plantes 1. Hachette \& Cie., Paris.

Baillon, H. 1868b. Mémoire sur la famille des Anonacées. Adansonia 8: 162-183.

Bentham, G. 1860. Notes on Annonaceae. J. Proc. Linn. Soc., Bot. 5: 67-72.

Boom, B.M. 1987. Ethnobotany of the Chácobo Indians, Beni, Bolivia. Advances Econ. Bot. 4: $13-14,51$.

Briggs, B.G. \& L.A.S. Johnson. 1979. Evolution in the Myrtaceae - Evidence from inflorescence structure. Proc. Linn. Soc. New South Wales 102: 157-256.

Britton, N.L. 1889. An enumeration of the plants collected by Dr. H.H. Rusby in South America IV. Bull. Torrey Bot. Club 16: 14-15.

Carvalho, R. \& A.C. Webber. 2000. Biologia floral de Unonopsis guatterioides (A.DC.) R.E. Fr., uma Annonaceae polinizada por Euglossini. Revista Brasil. Bot. 23: 421-425.

Chatrou, L.W. 1998. Changing genera. Systematic studies in Neotropical and West African Annonaceae: 117-119. Thesis, Utrecht University.

Chatrou, L.W., P.J.M. Maas, C.P. Repetur \& H. Rainer. 1997. Preliminary list of Ecuadorean Annonaceae. In: R. Valencia \& H. Balslev (eds.), Estudios sobre diversidad y ecología de plantas: 97-122. (Memorias del II Congreso Ecuatoriano de Botánica ... 1995). Pontificia Universidad Catolica del Ecuador, Quito / Universidad de Aarhus, Aarhus.

De Candolle, A.L.P.P. 1832. Mémoire sur la famille des Anonacées, et en particulier sur les espèces du pays des Birmans. Mém. Soc. Phys. Genève 5: 177-221.

DeWalt, S.J., G. Bourdy, L.R. Chávez de Michel \& C. Quenevo. 1999. Ethnobotany of the Tacana: quantitative inventories of two permanent plots of northwestern Bolivia. Econ. Bot. 53: 237-260. 
Diels, L. 1905. Anonaceae. In: R. Pilger, Beiträge zur Flora des Hylaea nach den Sammlungen von E. Ule. Verh. Bot. Vereins Prov. Brandenburg 47: 125-136.

Diels, L. 1924. Anonaceae. In: J. Mildbraed, Plantae Tessmannianae peruvianae 1. Notizbl. Bot. Gart. Berlin-Dahlem 9: 137-141.

Diels, L. 1931. Anonaceae novae. Notizbl. Bot. Gart. Berlin-Dahlem 11: 73-86.

Doyle, J.A., P.C. Bygrave \& A. Le Thomas. 2000. Implications of molecular data for pollen evolution in Annonaceae. In: M.M. Harley, C.M. Morton \& S. Blackmore (eds.), Pollen and spores: morphology and biology: 259-284. Royal Botanic Gardens, Kew.

Dunal, M.F. 1817. Monographie de la famille des Anonacées. Treuttel \& Würtz, Paris.

Eichler, A.W. 1875. Blüthendiagramme I. Engelmann, Leipzig.

Fries, R.E. 1900. Beiträge zur Kenntniss der Süd-Amerikanischen Anonaceen. Kongl. Svenska Vetensk. Acad. Handl., n.s., 34, 5: 1-59.

Fries, R.E. 1905. Die Anonaceen der zweiten Regnell'schen Reise. Ark. Bot. 4, 19: 1-30.

Fries, R.E. 1906. Studien in der Riedel'schen Anonaceen-Sammlung. Ark. Bot. 5, 4: 1-23.

Fries, R.E. 1907. Einige neue Phanerogamen aus der Süd- und Centralamerikanischen Flora. Bull. Herb. Boissier sér. 2, 7: 1002-1004.

Fries, R.E. 1919. Studien über die Blütenstandsverhältnisse bei der Familie Anonaceae. Acta Horti Berg. 6, 6: 3-48.

Fries, R.E. 1928. Zwei neue Anonaceen. Repert. Spec. Nov. Regni Veg. 24: 246-248.

Fries, R.E. 1931. Revision der Arten einiger Anonaceen-Gattungen II. Acta Horti Berg. 10: 143-151, 331-332.

Fries, R.E. 1937. Revision der Arten einiger Annonaceen-Gattungen IV. Acta Horti Berg. 12: 226, 230-264, 266-269, 281-282.

Fries, R.E. 1938. Annonaceae. In: J.F. Macbride (ed.), Flora of Peru. Field Mus. Nat. Hist., Bot. Ser. 13: 700-766.

Fries, R.E. 1939. Revision der Arten einiger Annonaceen-Gattungen V. Acta Horti Berg. 12: 289_ 577.

Fries, R.E. 1941. Neue amerikanische Annonaceen. Acta Horti Berg. 13: 103-116.

Fries, R.E. 1950. Contributions to the knowledge of the Annonaceae in northern South America. Ark. Bot. n.s. 1: 329-347.

Fries, R.E. 1955. Three new Annonaceae from Panama. Ann. Missouri Bot. Gard. 42: 151-152.

Fries, R.E. 1956. Some new contributions to the knowledge of the Annonaceae in Colombia and Mexico. Ark. Bot. n.s. 3: 433-437.

Fries, R.E. 1957a. New species of Annonaceae from the Upper Amazon Basin. Ark. Bot. n.s. 3: $599-606$.

Fries, R.E. 1957b. Annonaceae. In: B. Maguire \& J.J. Wurdack, The botany of the Guayana Highlands II. Mem. New York Bot. Gard. 9: 325-331.

Fries, R.E. 1959. Annonaceae. In: H. Melchior (ed.), Die Natürlichen Pflanzenfamilien, ed. 2, 17aII: 1-171. Duncker \& Humblot, Berlin.

Herzog, Th. 1909. Siphonogamae novae bolivienses in itinere per Boliviam orientalem ab auctore lectae. Repert. Spec. Nov. Regni Veg. 7: 51-52.

Hickey, I. 1979. A revised classification of the architecture of dicotyledonous leaves. In: R. Metcalfe \& R. Chalk, Anatomy of the Dicotyledons, ed. 2, 1: 25-39. Clarendon Press, Oxford.

Hohenkerk, L.S. 1919. Botanical identification of British Guiana trees and plants. J. Board Agric. British Guiana 11: 99.

Howard, R.A. 1988. Flora of the Lesser Antilles 4: 241. Arnold Arboretum, Harvard University, Jamaica Plain, Massachusetts.

Hutchinson, J. 1923. Contributions towards a phylogenetic classification of flowering plants II. The genera of Annonaceae. Bull. Misc. Inform. Kew 1923: 241-261.

Johnson, D.M. \& N.A. Murray. 1995. Synopsis of the tribe Bocageeae (Annonaceae), with revisions of Cardiopetalum, Froesiodendron, Trigynaea, Bocagea, and Hornschuchia. Brittonia 47: $248-319$.

Lobão, A.Q., R.C. Forzza \& R. Mello-Silva. 2006. Annonaceae da Reserva Biológica da Represa do Grama, Descoberto, Minas Gerais, Brasil, com uma nova espécie, Unonopsis bauxitae. Rodriguésia 57: 137-147. 
Maas, P.J. M., E.A. Mennega \& L. Y.Th. Westra. 1994. Studies in Annonaceae XXI. Index to species and infraspecific taxa of neotropical Annonaceae. Candollea 49: 389-481.

Maas, P.J.M., E.C.H. van Heusden, J. Koek-Noorman, A.K. van Setten \& L.Y.Th. Westra. 1986. Studies in Annonaceae VII. New species from the Neotropics and miscellaneous notes. Proc. Kon. Akad. Wetensch., Ser. C. 89: 249-278.

Maas. P.J.M., E.C.H. van Heusden, J. Koek-Noorman, A.K. van Setten \& L.Y.Th. Westra. 1988. Studies in Annonaceae IX. New species from the Neotropics and miscellaneous notes. Proc. Kon. Akad. Wetensch., Ser. C. 91: 243-282.

Maas, P.J.M., L.Y.Th. Westra, L.W. Chatrou \& Collaborators. 2003. Duguetia (Annonaceae). Flora Neotropica Monograph 88: 1-274.

Maas, P.J.M., L.Y.Th. Westra \& Collaborators. 1992. Rollinia (Annonaceae). Flora Neotropica Monograph 57: 1-188.

Martius, C.F.Ph. 1831. Reise in Brasilien ... in den Jahren 1817 bis 1820 gemacht von weiland Dr. Joh. Bapt. von Spix und Dr. Carl Friedr. Phil. von Martius 3: 1237. Reprint ed. K. Magdefrau. 1966. Brockhaus, Stuttgart.

Martius, C.F.Ph. 1841. Anonaceae. In: C.F.Ph. von Martius (ed.), Flora Brasiliensis 13: 1-64. Frid. Fleischer in comm., München, Leipzig.

Murillo-A., J. \& D. Restrepo. 2000. Las Anonáceas de la región de Araracuara (Estudios en la Amazonia colombiana XX): 1-218. Tropenbos Colombia.

Pirie, M.D., L.W. Chatrou, J. B. Mols, R.H.J. Erkens \& J. Oosterhof. 2006. 'Andean-centred' genera in the short branch clade of Annonaceae: testing biogeographical hypotheses using phylogeny reconstruction and molecular dating. J. Biogeogr. 33: 31-46.

Richardson, J.E., L.W. Chatrou, J.B. Mols, R.H.J. Erkens \& M.D. Pirie. 2004. Historical biogeography of two cosmopolitan families of flowering plants: Annonaceae and Rhamnaceae. Philos. Trans., Ser. B, 359: 1495-1508.

Rolfe, R.A. 1893. Flora of St. Vincent and adjacent islets. Bull. Misc. Inform. Kew 1893: 235.

Ruiz Lopez, H. \& J.A. Pavón. 1959. Flora peruviana, et chilensis 5. Anales Inst. Bot. Cavanilles 17: 411-432. Publ. by E.A. López.

Rusby, H.H. 1927. Descriptions of new genera and species of plants collected on the Mulford biological exploration of the Amazon Valley, 1921-1922. Mem. New York Bot. Gard. 7: 242-247.

Saint-Hilaire, A. F.C.P. 1825. Flora Brasiliae meridionalis 1. Belin, Paris.

Schatz, G.E. 1998. New species of Sapranthus B.C. Seemann and Unonopsis R.E. Fries (Annonaceae) from Mesoamerica. Novon 8: 436-440.

Schatz, G.E. \& P.M. Jørgensen. 1999. Annonaceae. In: P.M. Jørgensen \& S. León-Yánez (eds.), Catalogue of the vascular plants of Ecuador. Monogr. Syst. Bot. Missouri Bot. Gard. 75: 211-216.

Schultes, R.E. 1969. De plantis toxicariis e mundo novo tropicale commentationes IV. Bot. Mus. Leafl. 22: 134-136.

Schultes, R.E. 1977. De plantis toxicariis e mundo novo tropicale commentationes XVI. Bot. Mus. Leafl. 25: 114-115.

Schultes, R.E. 1978. De plantis toxicariis e mundo novo tropicale commentationes XXIII. Bot. Mus. Leafl. 26: 228-230.

Schultes, R.E. 1980. De plantis toxicariis e mundo novo tropicale commentationes XXVI. Bot. Mus. Leafl. 28: 11-14.

Schultes, R.E. 1993. Plants in treating senile dementia in the northwest Amazon. J. Ethno-pharmacol. 38: $129-131$.

Schultes, R.E. \& R.F. Raffauf. 1992. Vine of the soul. Medicine men, their plants and rituals in the Colombian Amazon. Synergetic Press, Oracle, Arizona.

Silberbauer-Gottsberger, I., G. Gottsberger \& A. Webber. 2003. Morphological and functional characteristics of New and Old World Annonaceae with respect to their mode of pollination. Taxon 52: 707-718.

Spichiger, R., J. Méroz, P.-A. Loizeau \& L. Stutz de Ortega. 1989. Contribución a la flora de la Amazonia Peruana. Los árboles del Arborétum Jenaro Herrera. I Moraceae a Leguminosae. Boissiera 43: 107-138.

Standley, P.C. 1925. New plants from Central America II. J. Wash. Acad. Sci. 15: 101-103. 
Steudel, E.G. 1843. Über einige surinamische Pflanzen. Flora 26: 754.

Systematics Association Committee for descriptive biological terminology. 1962. II. Terminology of simple symmetrical plane shapes. Taxon 11: 145-146.

Van Heusden, E.C.H. 1992. Flowers of Annonaceae: morphology, classification and evolution. Blumea, Suppl. 7.

Van Setten, A.K. \& J. Koek-Noorman. 1986. Studies in Annonaceae VI. A leafanatomical survey of genera of Annonaceae in the Neotropics. Bot. Jahrb. Syst. 108: 17-50.

Van Setten, A.K. \& J. Koek-Noorman. 1992. Fruits and seeds of Annonaceae. Morphology and its significance for classification and identification. Studies in Annonaceae XVII. Biblioth. Bot. 142: 1-101; pl. 1-50.

Van 't Klooster, C.I.E.A., J.C. Lindeman \& M.J. Jansen-Jacobs. 2003. Index of vernacular plant names of Suriname. Blumea, Suppl. 15.

Von Schlechtendal, D.F.L. \& A. von Chamisso. 1831. Plantarum mexicanarum a cel. viris Schiede et Deppe collectarum, recensio brevis. Linnaea 6: 417-418.

Walker, J.W. 1971. Pollen morphology, phytogeography, and phylogeny of the Annonaceae. Contr. Gray Herb. 202: 1-132.

Weberling, F. 1981. Morphologie der Blüten und der Blütenstände. Ulmer, Stuttgart.

Weberling, F. 1989. Morphology of flowers and inflorescences. Cambridge University Press, Cambridge.

Weberling, F. \& J. R. Hoppe. 1996. Comparative morphological evaluation of inflorescence characters in Annonaceae. In: W. Morawetz \& H. Winkler (eds.), Reproductive morphology in Annonaceae (Biosystematics and Ecology Series 10): 29-53. Österreichische Akademie der Wissenschaften, Wien.

Williams, L.O. 1963. Tropical American plants V. Fieldiana, Bot. 29: 545-547.

Zamora V., N., Q. Jiménez M., L.J. Poveda A. \& C. Aragón. 2000. Árboles de Costa Rica II. INBio, Santo Domingo de Heredia (CR).

Zamora V., N. \& L.J. Poveda A. 1988. Una nueva especie de Unonopsis R.E. Fries (Annonaceae) para Costa Rica. Phytologia 64: 399-401.

\section{IDENTIFICATION LIST}

The abbreviations behind the collector numbers refer to the following taxa:

$\begin{array}{lll}\text { Bocageopsis }(\mathrm{B}) & \text { Unonopsis }(\mathrm{U}) & \text { Unonopsis }(\mathrm{U}) \\ \text { cane }=\text { canescens } & \mathrm{duck}=\text { duckei } & \text { pend }=\text { penduliflora } \\ \text { matt }=\text { mattogrossensis } & \text { eleg }=\text { elegantissima } & \text { perr }=\text { perrottetii } \\ \text { mult }=\text { multiflora } & \text { esme }=\text { esmeraldae } & \text { peru }=\text { peruviana } \\ \text { plei }=\text { pleiosperma } & \text { flor }=\text { floribunda } & \text { pitt }=\text { pittieri } \\ \text { Onychopetalum }(\mathrm{O}) & \text { glau }=\text { glaucopetala } & \text { rena }=\text { renati } \\ \text { amaz }=\text { amazonicum } & \text { guat }=\text { guatterioides } & \text { ried }=\text { riedeliana } \\ \text { peri }=\text { periquino } & \text { hamm }=\text { hammelii } & \text { rufe }=\text { rufescens } \\ \text { Unonopsis }(\mathrm{U}) & \text { hete }=\text { heterotricha } & \text { sanc }=\text { sanctae-teresae } \\ \text { aste }=\text { asterantha } & \text { long }=\text { longipes } & \text { seri }=\text { sericea } \\ \text { aura }=\text { aurantiaca } & \text { macr }=\text { macrocarpa } & \text { sess }=\text { sessilicarpa } \\ \text { avic }=\text { aviceps } & \text { magn }=\text { magnifolia } & \text { silv }=\text { silvatica } \\ \text { bahi }=\text { bahiensis } & \text { megp }=\text { megalophylla } & \text { sp. }=\text { unidentified to } \\ \text { baux }=\text { bauxitae } & \text { megs }=\text { megalosperma } & \\ \text { bull }=\text { bullata } & \text { mexi }=\text { mexicana } & \text { spec }=\text { spectabilis } \\ \text { caul }=\text { cauliflora } & \text { mont }=\text { monticola } & \text { stev }=\text { stevensii } \\ \text { colo }=\text { colombiana } & \text { onyc }=\text { onychopetaloides } & \text { stip }=\text { stipitata } \\ \text { cosn }=\text { costanensis } & \text { osae }=\text { osae } & \text { stor }=\text { storkii } \\ \text { cost }=\text { costaricensis } & \text { paci }=\text { pacifica } & \text { theo }=\text { theobromifolia } \\ \text { dari }=\text { darienensis } & \text { pana }=\text { panamensis } & \text { vene }=\text { veneficiorum }\end{array}$


Acevedo et al. 1580: U flor; 6663: U guat; 6876, 6949: U aff. dari; 7386: U vene; 8224: U stip; 8365: U guat; 10380: B mult - Acosta, L. 33: U theo - Acosta S., M. 12280, 12539: U esme - Adair INPA 72941, INPA 72955: U guat - Agostini \& Fariñas 96: U cosn - Aguilar, M. et al. 736: O peri; 740: U flor; 867: O peri; 896: U flor; 930: U guat; 1198: O peri - Aguilar, R. et al. 144: U pitt; 368: U osae; 672: U pitt; 953: U stor; 995: U bull; 1763: U theo; 2363, 2416, 3410: U pitt; 4655: U theo; 5205: U sp. - Aguinda et al. 1416: U flor - Aguirre et al. 314: U sp. - Aizprúa \& Alvarez B 4213: U bull - Albuquerque et al. 257: B mult; 1137: U stip - Alexiades et al. 105, 272, 279, 787, 969: U flor - Allen 2647: U pana; 5839: U osae; 5938, 6658: U pitt - Almeida 1121: U stip; 3570, 3677, 3813: U guat - Alvarado 312, 419: U flor - Alverson et al. 315: U megp - Amaral et al. 129: U guat; 451: U flor; 511: U stip; 755: B mult; 1276: U guat; TF-4-45, TF-7-78: O amaz - Amorim et al. 357, 1885, 2123: U bahi - Ancuash 92: U aste; 376, 1307, 1389: U guat - Anderson, C.W. 389: U glau - Anderson, W.R. et al. 11877, 12290: U guat - Antonio 1369: U pana - Aranguren \& Aranguren 104: O peri - Araújo 231: U bahi - Araya et al. 247: U hamm - Arbo et al. 5571: U bahi - Arévalo G. et al. 76: U spec; 100: U guat - Argent 6736: U guat - Aristeguieta 3777: B mult - Aronson \& Rodrigues 844: U vene - Arroyo et al. 349: B matt - Asplund 14579, 14759: U flor; 14821: U vene - Assunção et al. 141: B mult; 639, 641, 683: U duck - Aulestia, C. et al. 196: U magn; 342, 556, 1011: U onyc - Aulestia, M. et al. 21: U vene; 297: U flor; 464, 612, 635, 685: U vene; 1750: U flor; 2069: U vene; 2661, 2908, 2926: U flor; 3046: U vene; 3612: U sp. - Austin et al. 7392: U guat - Ayala et al. 1531: U sp.; 2049, 2371: U vene; 2841: U guat; 2983: U vene; 3563: U guat; 6430: U sp.; 6443: U flor; 6447: U spec - Aymard C. et al. 6728: U spec; 8039: B mult; 8145: B cane; 8146: B mult; 10019: U guat.

BAFOG - Service Forestier 7106: U perr; 7247, 7256: U rufe; 7266, 7289: U perr; 7776, 7963: U guat - Balderrama 182: U guat - Balée \& Silva 5104: U guat - Balslev et al. 84645: U magn; 84713, 97176: U flor - Bamps et al. 5232, 5306: U rufe; 5444: U stip - Bang 1952: U guat - Barbosa 6519: U aff. dari - Barbour 5538, 5708: U flor - Barrier 1928B, 4131: U stip; 4841: U rufe - Barros 1199: U guat - Bastos 179: U perr - Batalha 3506, 3606, 3712: B matt - Bawa 562: U pitt - Beck, H.T. et al. 42: U stip; 213: U guat; 1058: U peru; 2240: U onyc - Beck, S.G. 12715, 12749, 20060, 24311: U guat - Begazo 161: U flor - Bello et al. 1625, 1872, 2229: U cost - Belshaw 3140: U guat - Beltrán et al. 433: U peru; 5798: U eleg - Berg et al. P18612: B mult; P19743: U guat; P25798: B mult - Berlin 561: U guat; 643: U aste - Bernardi, A.L. 897: B mult; 3027: U glau; 6592: B mult; 7196: U glau; 7289: B mult - Bernardi, M. 19436: U guat - Berry et al. C. 1520: U stip; 2188: B mult; 7041: U stip - Betancur \& Churchill 2180: U vene - Bettella 151: U guat - Bicudo et al. 52: U guat - Bisby et al. P18089: B mult - Black 47-1990: U guat - Blanco 1127: U stip; 1163: B mult - Blum et al. 1712: U pana - Bolivia '89 199: O peri — Boom et al. 1768: U rufe; 1818: U perr; 4102, 4442: O peri; 5003: U guat; 8169: U glau; 8527, 8720: U duck; 10337, 10481: B mult - Bordenave et al. 405, 5208: U stip - Borsboom LBB 11990: U rufe - Bourdy 1752: U guat - Boyle et al. 1220, 2820: U pend; 2849, 3685: U esme - Braga \& Nascimento 3248: U vene; 3339: U stip; 3348: U vene - Brand et al. 184, 936, 1235: U paci - Brandbyge et al. 36089: U magn - Breteler 3799: U glau; 4780: B mult; 4839: U guat - Brito, H.S. \& Da Vinha 129: U bahi - Brito, J.M. 19: B mult - Buchtien 739, 1994, 2010, 2048: U guat - Burchell 6731, 7217, 9146, 9801: U guat - Burger et al. 10523: U stor; 10618: U osae; 11112: U pend - Buscalioni 2723: U guat - Buttura 287: U guat - BW (Suriname) 565, 656, 786, 1652: U rufe; 2023, 2060: U guat; 2447, 3403: U rufe; 3788: U glau; 3951, 3993: U rufe; 4436: U guat; 4683, 4694: U rufe; 5574: U guat; 6161, 6313: U glau; 6429, 6482: U rufe; 6586: U stip; 6621: U rufe.

Callejas et al. 2719: U aff. pitt; 4580: U paci; 5430: U long; 5486: U sess; 5685, 5785, 5809: U colo; 9248: U avic; 9320: U paci - Campbell et al. 8362: U flor; 9647: U spec; 14842: U perr; P22400: U guat; P22532: U hete - Campos, J. et al. 3630, 3910, 4324, 5450: U mont - Campos, M.T. et al. 19: B mult; 40, 52: O amaz - Capucho 419: B plei; 555: O amaz; 559: B mult - Carballo 179: U pitt - Cárdenas L. et al. 440, 491, 585, 719, 722, 931, 1153, 1398: U colo; 2560, 2589: U avic; 4302: U guat; 4614: U vene - Carnevali et al. 1672, 1749: U stip - Carreira et al. 601: U guat - Carvalho et al. 160, 656, 2100: U bahi; 2272: U guat; 3216, 4472, 4542: U bahi Castillo S. 2165: U spec; 3807, 4944, 5158, 5667, 6439, 6474, 6667, 8083: U guat - Castro, M. 
et al. 91: U guat - Castro, R.M. et al. 745: U baux - Centeno \& Janovec 140, 227: U guat - Cerón M. et al. 274: U sp.; 2386, 2502, 3241, 3934, 3952, 5076, 5403, 6351, 7706, 7781: U vene; 8025, 16160: U flor - Chacón, A. et al. 109: U pend; 741: U aff. cost; 1022: U osae - Chacón, I.A. 181: U pend - Chanderbali et al. 40: B mult; 397: U guat; 492, 544: U glau - Chareyre 4d: U guat - Chatrou et al. 16: U guat; 41: U theo; 62, 68: U pitt; 132, 134, 140: U guat; 160: U stip; 171: U vene; 200: U flor; 203: U guat; 218: U vene; 228: U guat; 237: U stip; 250: U eleg; 253: U stip; 260: U vene; 337: U. guat; 357, 390: B mult; 422: U guat; 425, 439: O peri; 506: U pitt - Chavarría et al. 506: U pitt - Chavez 185: U spec - Chaviel 350: B mult - Chocce et al. 542: U sp. - Chota 143: B cane - Chrostowski 70-478: U guat - Cid F. et al. 705: B mult; 971, 1003: U stip; 1334, 1401, 1547, 1743: U guat; 1906: U stip; 1959: U duck; 2027, 2456, 2587, 3295, 3398, 3772: U guat; 4090: B mult; 4687: U guat; 5256, 5768, 6655, 6694: U stip; 6914: U guat; 7189: B mult; 7333: U stip; 7412: U duck; 7534: B mult; 7567: U stip; 7736: U guat; 7769: U stip; 7964: U guat; 8273: U eleg; 8368: O amaz; 8433, 8469, 8776, 9557, 9600: B mult; 9603: U stip; 9846: U guat; 9977, 9985: U stip; 10068: U flor; 10099: U stip; 10375: B mult; 10463, 10500: U flor; 10603: U spec; 10762: U guat; 10791: U spec; 10796: U flor - Clark 6923, 7270 : U stip - Clarke et al. 539, 1544: U guat; 1560: U stip; 1963, 2216: U guat; 2729: U stip; 2772, 3006: U guat; 3122: U stip; 3503, 3973: U guat; 4194: U rufe; 4308: U stip; 4544: B mult; 4783, 5055, 6534, 6605, 6643: U guat; 7060, 7613, 7776: U stip; 7837: B mult; 7909: U guat; 8426: B mult; 8752, 8810: U guat; 9673, 9708: U glau - Coêlho, D. INPA 2168, INPA 3297: B mult; INPA 42234: O amaz - Coêlho, L. et al. 130, 136: B mult - Coêlho, L.S. et al. 208: U stip; 253, 304: U guat; 2000: O peri - Coello 79: U vene - Cogollo et al. 318, 362: U avic; 375: U sess; 969, 1233: U paci; 1241, 1424, 1529, 1630, 1726: U sess; 3390: U long - Colchester 2333: U stip - Colella et al. 1664: U guat - Contera 146: U stip - Contreras, E. 6239, 7830, 8868, 9014, 10029, 10031, 10035, 11460, 11461: U pitt - Contreras, J. 155: B mult - Cooper et al. 198: U pitt; 250: U sp. - Cordeiro, I. et al. 263: U stip; 966: U guat - Cordeiro, M.R. 1065: O peri - Cordero 276: U theo - Córdoba et al. 381: U guat; 1109: B mult - Cornejo \& Balarezo 2933: U spec - Cornejo S. et al. 4481: U vene; 6218, 6489: U esme; 7494: U flor; 7777: U magn - Correa A. et al. 744: U pana; 3310: U stor; 9178, 9735: U pana; 10401: U pitt - Cortés et al. 213: U eleg - Costa et al. 10: B mult - Cowan 39341: U glau - Cremers et al. 5111: U guat; 6462: U stip; 7545: U guat; 8229, 8244: U stip; 9866: U guat; 12041, 13666, 13814 : U stip - Croat et al. 5198, 9577, 11871: U pitt; 18397, 18411, 18427: U vene; 18588, 18608: U peru; 19049: U stip; 19091: U vene; 19205: U guat; 19469, 19546, 20168: U vene; 20534: U stip; 20653A, 20655, 20780, 20825: U vene; 21980: U pitt; 22841: U bull; 51104, 51148: U guat; 51189: U spec; 59852: U osae; 59868: U theo; 62482A: U flor - Cruz, A. et al. 5, 162, 204: U flor - Cruz, J. et al. 305: O amaz - Cuadros V. et al. 940, 3875: U paci - Cuatrecasas et al. 14265, 15973, 17747, 21361, 26026: U pac - Cunha et al. 870: O amaz.

Daly et al. 1916: O amaz; 2085: U guat; 3930: U rufe; 3986: U perr; 4132: U stip; 4244, 4287: B mult; 5163: U esme; 5623: U flor; 5778: U spec; 6154: U guat; 6559: U flor; 7043, 7280: O peri; 7409: U guat; 7834, 7883, 8001: O peri; 8006: U guat; 8585: U flor; 8920, 9501, 9757: U guat; 10069, 10129, 10140: U flor; 10857: U guat; 10888: U vene; 10967: U spec; 11570, 11792: U flor - Damião 2732: U flor - Davidse et al. 15347: B mult; 17882: U guat; 26282: U cost; 27869: B cane; 30932: U pitt - Davidson et al. 5294: U stip; 5408, 9869, 9917: U guat; 9992: B mult - Davis 100 (= FDBG 2091), 470 (= FDBG 2465): B mult - De Bruijn 1599: U avic - De Granville et al. C 8, 12: U stip; 2108: U guat; 2558, 3310: U stip; B 3638: U glau; 4643, 4685: U guat; 4758, 4802: U stip; B 4894: U guat; B 5440: U stip; 5580: U rufe; 5739, 5837, 6105, 6145, 6247, 6260, 6274, 6435, 6513, 7330, 8002: U stip; 9582, 10035, 10222, 10262: U guat; 10465, 11318, 11319, 11427, 11428, 11751, 13146, 14807, 15417, 15678: U stip - De la Cruz 3857, 4227, 4398: U glau — De Nevers et al. 3634: U pana; 5324: U stor; 5964: U pana; 6744, 6758: U stor; 7376: U pitt; 7413: U bull — De Vletter LBB 16332: U guat - Defler 24: B cane - Del Aguila et al. 81, 106, 111, 530 B: U flor - Delgado 387: B mult; 842: U spec - Devia A. et al. 3796: U ? sess - DeWalt et al. 163, 568: U flor - Díaz \& Pereira, J. 9055, 9127: O peri - Díaz B. et al. 16: U peru; 23: U vene; 24: U stip; 29: B cane; 31, 34: U vene; 36, 37: U stip; 38: U vene; 45: U stip; 65 A: U flor; 79: U eleg - Díaz S. et al. 169: U guat; 393, 394: U stip; 431: U guat; 537: U stip; 854 A, 912: U flor; 1337: U stip; 1544: U vene; 1546: U stip; 7313: 
U spec; 8700: U mont; 8918: U guat; 9174, 9180, 9296: U flor; 9331: U guat; 9532, 9537, 9554 : U flor - Dick 166: U rufe - Dik et al. 34: U vene; 263, 516: U flor; 967: U vene; 1677: U flor - Dionízia et al. 92, 125: U duck - Dodson et al. 5143, 6490: U magn - Dressler 3443: U pana - Duarte et al. 5681: U guat; 5979: U bahi; 9826: B plei - Dubs 947, 1997: U guat - Ducke 6 (= RB 23985), 7 (= RB 23896): B mult; MG 11501: B matt; RB 11374: O amaz; RB 17869: B matt; RB 19621: U guat; RB 19633: B mult; RB 23890: U stip; RB 23898: U flor; RB 29009: U guat; RB 29010: U duck - Duke 9099: U paci; 9333, 9358: U pana; 9878: U paci; 11603: U colo - Dunlap 454: U stor — Duque \& Posada 4012: U eleg — Duque-Jaramillo 2321: U flor - Dwyer et al. 4861, 8308, 11884: U pana - Dziewa 18: B matt.

Echavarría \& Morales 217: U paci - Eggers 6882: U guat - Egler \& Irwin 46580: U guat - Ek et al. 745, 781: B mult; 841: U rufe; 1167: U perr; 1225: U stip - Encarnación 26135: U spec; 26220: U flor - Espina et al. 2058: U paci; 3134: U colo; 3300: U paci - Espinoza et al. 157: U spec; 371, 819: U flor — Evans et al. 1577: U pitt; 1946: U guat; 2099: U glau; 3097: U stip. Faber-Langendoen \& Hurtado 1870: U cf. dari - Fanshawe 2481 (= FDBG 5217): B mult; 4900 (= FDBG 2164): U perr; 5000 (= FDBG 2264): U glau; 5564 (= FDBG 2765): U rufe; 5565 (= FDBG 2766), 6049 (= FDBG 2902): U perr; 6950 (= FDBG 3386): U guat - Farias 351: U aura - Fernández, Ang. et al. 2276, 4320: B mult; 4512: U guat; 5086: B mult; 7998: U stip - Fernández, V. 18: B mult - Ferreira 58-257, 81-57: U guat - Feuillet et al. 684, 1184, 10022: U stip; 10025: U perr; 10068: U stip; 10085: U rufe; 10095, 10169: U stip - Fiaschi et al. 706: U sanc; 1532, 1779: U bahi - Figueiredo et al. 139: U guat; 176: O peri; 520: U flor; 652, 1074: U guat - Fletes \& Rojas 377: U pitt - Fleury 837: U glau; 1080: U rufe - Florschütz \& Maas 3147: U glau - Foldats, E. \& Velazco, J. 9144: U stip; 9205: B mult - Folsom et al. 1487, 2601: U stor; 4324, 4364: U macr; 5680: U megs - Fonnegra G. et al. 1812: U colo; 1878, 2211: U paci; 6719, 7007, 7768: U avic - Forero et al. 3855: U paci; 4606: U sp.; 4917: U paci; 8859: U colo - Forest Dept. Brit. Guiana 2091: B mult; 2164: U perr; 2264: U glau; 2465 : B mult; 2639: U perr; 2765: U rufe; 2766, 2902: U perr; 3386: U guat; 4835, 4900: U perr; 5000 : U glau; 5217: B mult; 5564: U rufe; 5565, 5600; 6049: U perr; 6183: U rufe; 6922: U perr; 6950: U guat - Forsyth s.n.: Insufficiently known species U. umbilicata - Forzza et al. 2222: U baux - Foster et al. 560, 1709: U pitt; 1761, 1866: U pana; 3145: U flor; 3616, 3675, 3746: U vene; 4212: U guat; 4382: U vene; 4387, 4424, 4743: U stip; 5057: U flor; 5246, 6034, 6115: U. guat; 7928, 8931: U vene; 10978, 12482, 12529: U guat; 12538, 13384: U flor; 14665: U stor; 14705: U bull - Fournet 879: U guat - Franco et al. 3451: U megp; 3872: U eleg — Frankie 54a, 54C: U pitt - Freire et al. 2196: U onyc; 2974: U spec - Freitas 6, 9: U flor - Freitas, L. 7-1-55, 7-1-94: U flor - Freitas, M.A. et al. 414: O amaz; 451: B mult - Fróes et al. 1700, 11831: U guat; 20484: B mult; 21110: U stip; 22126: B mult; 23827, 24778: U guat; 25308: B cane; 25488, 26449, 26689, 27262, 27586, 27675: U guat; 28443: B mult; 28710: U stip; 31565, 32137: $\mathrm{U}$ guat; $32206: \mathrm{O}$ amaz.

Galdames et al. 1317: U dari; 1445: U bull; 1538: U long; 1923: U stor; 4137: U pana - Galeano et al. 5509: U aff. dari - García C. \& Agualimpia 501: U aff. dari - García-Barriga 15425: U colo - Garwood et al. 87: U dari; 1177: U pana; 2850B, 2940A: U pitt - Geijskes 1019: U glau - Gentle 4808: U pitt - Gentry et al. 3183, 3275, 3314: U pana; 3323, 3344, 3358: U stor; 5147: U pitt; 7452, 7460, 7471, 8727: U pana; 9129: U sp.; 9438: U paci; 10152: U magn; 13230, 13241: B mult; 15622: U stip; 15799: B cane; 16146: U spec; 18677: U ? guat; 20012: U avic; 20428: U vene; 21004: U stip; 21061, 21095: U vene; 21117, 21184: U stip; 21898: U vene; 22432: B cane; 22480: U stip; 24487: U cf. darie; 24972: U peru; 25014: U vene; 25226: B cane; 25294: U stip; 25369: U guat; 25475 A: U guat; 25621: U spec; 25966: U stip; 26064: U vene; 26075, 26091, 26099: U stip; 26885: U guat; 26912, 26960: U sp.; 26978: U flor; 27019: U sp.; 27026: U flor; 27227: U guat; 27440, 27441: U vene; 27595: U stip; 27802, 27819: U vene; 27865: U guat; 27954: U vene; 28088: U flor; 29046, 30019: U vene; 30047: U stip; 30131: U cf. dari; 30145, 30151: U colo; 31561, 31633: U stip; 31724: U vene; 31897: U guat; 31958, 31982, 31983: U sp.; 35555: U colo; 36232: U sp.; 36343: U flor; 36957: U long; 38075, 38091: U flor; 38795: U stip; 39249, 39300, 39368: B cane; 39589, 39666: U vene; 40297, 40302: U colo; 40618: U paci; 41125: U pana; 41376: U guat; 41751: U vene; 41851: U spec; 42259, 42425: U vene; 42447, 42519: U flor; 42537: U spec; 42670, 42699A: U stip; 42707: U guat; 43025, 43041: U flor; 
43149: U guat; 43155: U vene; 43175: U guat; 43337: U sp.; 43404: U flor; 43526: U guat; 43539: U sp.; 43544, 43806, 45675, 45694: U guat; 45797: U sp.; 45900: U guat; 45954: U sp.; 46215: U guat; 46919: B cane; 48576: U pitt; 49010: U stip; 52284: U aste; 54202: U guat; 54268: U vene; 54517: U spec; 54622: U flor; 54631, 55641: U vene; 55812: U flor; 55826: U vene; 55835: U sp.; 55904: U vene; 56225: U flor; 56460: U stip; 57272, 57375: U colo; 57399: U megp; 57553: O peri; 57699: U sp.; 61787: U flor; 61878: U spec; 61942: U sp.; 63105: U stip; 63352, 63376, 63522: U spec; 64190A: U vene; 64850: U sp.; 64945: U stip; 65605: U sp.; 65778: U flor; 65905: U guat; 65927: U flor; 68430: U ? sess; 68723, 68844: U guat; 68909: U flor; 69251: U ? stip; 69256: U stip; 69297: B mult; 69326, 69329: U guat; 69561: O peri; 69787: U flor; 69827, 70296: U guat; 70383: O peri; 70515, 70673: U guat; 71703A, 71725A: U pitt; 71762 A: U hamm; 72086, 72295: U vene; 73838: U guat; 74264: U flor; 74342: U stip; 75864: U ? paci; 77736: O peri; 77903: B mult; 78081: U flor; 79409: U theo; 80148: U sp..; 80647, 80817: U spec - Gil 38: U avic - Gillespie et al. 1507: U stip; 1562, 2268, 2317: U guat - Giraldo G. \& Zea J. 35: U sess - Glaziou 20638: U guat - Goldstein \& Salas 281: B mult - Gomes, M. et al. 829, 831: O amaz; 1047, 1127, 1813: B mult - Gomes Jr. 1945: U guat - Gómez, J. A. 566: U long - Gómez, L.D. et al. 22727: U pitt - González, A. \& Ortega, F. 1213, 1218: U cosn - González, J. et al. 477: U pitt; 1607: U stor - Gordillo R. et al. 307: U guat - Gottsberger et al. 11-121093, 11-141093, 31-26990: U guat; 115-29985: U stip - Graham 2419, 2605: U flor - Grández et al. 228, 255: U flor; 875: U vene; 1105: U flor; 1173, 1463: U guat; 1534: U flor; 1599, 1610: U aste; 1691: U guat; 1947, 2005, 2010: U flor; 2146: U stip; 2286: U spec; 2292: U vene; 2320: U flor; 2363: U vene; 2447, 2531: U stip; 2617: U guat; 2663A: U spec; 2799, 2860: U stip; 4192: U flor; 4588: U spec; 4866: U flor; 5254, 5305: B cane - Grayum et al. 3600: U pitt; 4342, 4418: U stor; 5039: U pend; 5484, 5835: U theo; 6192, 6938: U pend; 8305: U theo; 9772: U pitt; 9822: U stev; 10605: U pitt - Grenand 3161: U stip - Grewal 92 (= FDBG 6183): U rufe - Grijalva et al. 352: U vene - Guánchez et al. 85: U spec; 335: U stip; 380: U spec; 3283: U stip; 4560: B mult - Gudiño et al. 504: U magn; 867, 2056: U flor; 2157, 2187: U vene - Guillén, J. et al. 116: U guat; 264: O peri - Guillén, R. et al. 1487, 1507, 1826, 1838: U guat; 2370, 2492: O peri; 4338: U guat - Gutiérrez et al. 548, 1449: U guat.

Hage \& Dos Santos 803, 881: U bahi - Hahn 3706: U stip - Hamilton \& Stockwell 3687: U bull - Hammel et al. 1849: U pana; 4949: U pitt; 9423: U hamm; 10592: U pitt; 11608: U hamm; 11636: U pitt; 12099: U pend; 13013: U pitt; 14386: U pana; 16230: U paci; 16663: U pitt; 16946: U osae; 18240: U pitt; 21292: U guat; 21336: U stip; 21622: U guat; 21658: U stip - Harley et al. 10597, 10599: U guat; 10843: B matt; 10985: U guat; 22186: U bahi - Hartman 12294: U dari - Hartshorn 951, 1327: U pitt - Hatschbach et al. 25297, 32452: U guat; 34962: B matt; 40617, 45233, 49300, 62331, 62764: U guat - Haught 1374: U paci - Hazlett 7486: U pitt - Henkel et al. 290, 565, 2694: U glau; 3148, 4638: U guat; 5238: U stip; 6730: U perr - Hensold 1134: U dari - Heringer, E.P. et al. 13127, 15283, 16773, 17643, 17830: U guat - Heringer, P. et al. 807: U guat - Hernández, H.M. et al. 760: U pitt - Hernández, J. J. \& Hoyos 65: U avic - Herrera, G. et al. 2169: U hamm; 2691: U aff. cost; 3024: U stor; 4152: U pitt; 4459: U theo; 4486: U osae; 6661: U theo; 7709: U stor; 7800: U pitt; 8753: U cost - Herrera, H. et al. 696, 744, 979: U dari; 1131, 1216: U pitt; 1309: U stor; 1478: U long; 1804: U pitt - Herzog 405: U guat - Heyde \& Lindeman 201: U glau - Hoehne 3521, 3522: U guat - Hoff et al. 6606, 6618: U guat - Hoffman et al. 3920, 3939: B mult; 3991: U rufe; 4030, 4615: B mult; 4816: U rufe - Holm-Nielsen et al. 21820, 21826, 22277, 22490, 22694: U vene - Holst et al. 3191: B mult; 5134: U pitt - Holt \& Blake 527: U guat - Hopkins \& Nascimento 1507: B mult - Hostmann \& Kappler 1116: U guat - Hoyos \& Hernández 382: U avic; 509, 996: U sp. A [p. 537] - Huashikat 124: U guat; 444, 2116: U aste - Huber, J.E. 4254: U guat - Huber, O. 4119: U stip; 5267: B mult - Huber, W. et al. 44: U theo; 134: U osae; 153, 285: U pitt; 365, 733: U osae; 910: U pend; 1057: U pitt; 1067, 1219: U theo - Hurtado et al. 388, 2613, 3082: U flor; 3090: U vene.

Idrobo et al. 8886: U vene; 11498: U stip - Irvine 744: U vene - Irwin et al. 17135, 17498, 25194: U guat; 47171, 47577: U stip; 47616, 47623, 47689, 48190, 48726: U guat; 54593, 55076: U stip; 55874: B mult - Ivanauskas et al. 2138: B matt.

Jacquemin 2497: U guat; 2589: U stip; 2789: U guat - Jangoux \& Bahia 693: U guat - Janovec et al. 1838: U guat; 1859: O peri; 2043: U flor; 2462: O peri - Jansen-Jacobs et al. 1659: U guat; 
2013: U stip; 2460: U guat; 3179: B mult; 5625, 5653: U guat; 5815: U glau - Jaramillo, J. et al. 13543: U vene; 13869: U esme; 30925 A: U vene - Jaramillo, N. et al. 325, 791: U spec; 1095, 1188: U aste; 1241: U peru - Jaramillo M., R. et al. 2760: U sp. - Jardim, A. et al. 59: U guat; 1004: O peri - Jardim, J.G. et al. 291: U bahi - Jenman 4252: U glau - Jesus 2343: U bahi — Jiménez, S. et al. 1224: U guat - Jiménez M., Q. et al. 459: U osae; 588: U pitt; 798: U stor; 1663: U pitt - Jiménez-Saa LBB 14251: U glau - Johnson et al. 1842: U bahi - Johnston 1545, 1595, 1629, 1643: U bull; 1655: U pana - Jones \& Facey 3519: U pitt - Junikka \& Orava 3071: U rufe.

Kajekai \& Wisum 463: U spec - Kallunki \& Pirani 468: U bahi - Kanhai LBB 13298: U rufe - Kappler 66: U guat - Kawasaki et al. 323, 347: U stip; 366: O amaz - Kayap 19, 278, 349, 625, 1024: U guat - Kegel 1362 : U guat - Kennedy et al. 457: U pana; 478: U pitt; 1853, 2115 : U pana; 2690: U pitt; 3067: U pana - Kenoyer 360: U pitt - Kernan et al. 420, 429: U pitt; 1042: U osae - Killeen et al. 2886, 2941, 3407: U flor; 3472, 3485, 3583, 3652, 4005: U guat; 5804, 5918: O peri; 5979: U guat; 6799: O peri - Killip et al. 27086: U vene; 27578, 27985: U guat; 28283: U ? peru; 28431, 28583, 28824: U guat; 29304, 29340, 29370, 29530, 29719 , 29723, 29733, 29935: U vene; 30077, 30079: B mult; 30099: U stip; 37434: U guat - Kirkbride Jr. et al. 1222: U macr; 1237: U cf. dari; 3213, 3442: U guat - Klug 974: U flor; 1556: U vene; 2524: U eleg; 3839, 4062: U guat - Knab et al. 42: B mult - Knapp et al. 1409: U pitt; 3093: U pana; 3170: U dari; 3605: U pitt; 7057: U guat; 7613: U aste; 8071: U guat - Knob et al. 1171: O amaz - Knudsen \& Tollsten 106: U magn - Korning \& Thomsen 47462: U vene - Kröll et al. 328, 852: U flor - Krukoff 1373: O amaz; 4806, 5178: U flor; 5326: O peri; 5992, 6069: U flor; 6168: U guat; 6883: B mult; 6909: O amaz; 7945, 8035: B mult; 8137, 8149: U vene; 8214: O peri; 8621: U flor; 8801: U stip; 8989: U flor - Kubitzki et al. 84-81: U guat - Kuhlmann, J.G. 1619: U flor; RB 24261: B mult - Kuhlmann, M. 1597, 1624: U guat - Kujikat 64, 270: U guat - Kurtz et al. RB 328311: U ried - Kvist et al. 1653: U sp.

La Rotta \& Martínez 667: U colo - Labroy 107: U guat - Laguna 98, 150: U pitt - Lamotte 506: U flor - Lanjouw et al. 811: U rufe; 2391: U stip; 2503: U rufe; 2503a: U stip - Lao et al. 50: U stor; 91: U pitt; 161: U bull — Larpin 884: U stip; 911: U rufe - Lawesson et al. 39685, 39741: U vene - Lawrance 636: U caul - Leguízamo et al. 1073: U colo - Lent 2289, 2328: U pitt - Leprieur 309: U guat - Lescure 874: U stip - Leveau 237: U guat - Lewis, G.P. et al. 1173: U bahi - Lewis, W.H. et al. 3439: U stor; 5454: U pana - Lhotzky 3: U guat - Liesner et al. 1956: U osae; 3316, 4050, 4116, 6771: U stip; 9981, 10781: U cosn; 16437, 17488: U stip; 26025 : U pitt - Lima, D.A. \& Black 48-3151: U guat - Lima, H.C. et al. 2712: B mult - Lima, J. et al. 1046: U guat — Lindeman et al. 1689: U guat; 3546: U glau; 3553, 4069: U rufe; 5019: U glau; 5023: U rufe; 5321, 5346, 5497: U guat; 6060: U rufe; 6271: U guat; 6422, 6482: B mult; 6652, 6655, 6656: U guat; 6834, 6894: U rufe - Lindeman, Görts-van Rijn et al. 209: B mult — Lindeman, Mennega et al. 165: U guat - Lindeman, Stoffers et al. 365: U rufe; 401: U glau; 547: U guat - Lindman A2973: U guat - Lisboa et al. 1927: U spec - Lissot VEN 106814: B mult - Little et al. 641: U flor; 721: U spec; 9647: U flor - Lleras et al. P17417: U vene - Loaiza \& Cogollo 35: U sess - Lobo et al. 131: U guat - Loiselle 157: U pend - Loizeau \& Mejia 425: U flor - Londoño et al. 1190: B cane - Loubry 131: U stip; 1165: U guat; 1386: U rufe; 1517: U guat; 1676: U stip - Loureiro et al. 6758: U duck; INPA 16446: B mult; INPA 37522: U guat; INPA 37676, INPA 37952: B mult; RB 314138: U duck; INPA 38838A: U guat - Lozano C. et al. 593: U vene - Lundell \& Contreras 20053, 20759: U pitt.

Maas et al. 2789: U megs; 5969, 6018, 6031, 6037, 6179, 6182, 6184: U guat; 6229: U spec; 6232: U guat; 6242: B cane; 6243, 6250: U vene; 6251, 6261: U stip; 6262: U eleg; 6270: U peru; 6293, 6294: U guat; 6358: U stip; 6361: U vene; 6365: B cane; 6503: U paci; 6762, 6773, 6774: U stip; 6837: U guat; 6841: U stip; 6953: B mult; 7136: U rufe; 7140, 7445: U perr; 7865: U theo; 7922: U stor; 7963: U pitt; 8092: U rufe; 8093: U stip; 8197: U guat; 8225: U flor; 8245, 8253: U vene; 8274: U stip; 8275: U vene; 8290: U guat; 8576, 8610: U vene; 8706: B mult; 8825: U aura; 8831, 8832: U sanc; 8944: B cane; 9092: U stip; 9205, 9232: U spec; 9243: B cane; 9255: O peri; 9323: U perr; 9430: U hamm; 9463: U theo; 9499: U osae; 9500: U pitt; 9522: U hamm; 9526, 9530: U stor; 9532, 9560, 9576: U bull; 9722: U stor; LBB 10697, LBB 10736: B mult; P12650: U stip; P13121: U guat; P13290: U spec - MacDougal et al. 3805: U long - Maceda 41, 395: O peri; 
399: U guat; 1022: U flor; 1200, 1292: U guat - Macedo, A. 1321, 4186: U guat - Macedo, M. et al. 1429: B matt - Maciel \& Rosário 1710: O peri - MacRae \& Rojas S. 125: U guat - Madriñán \& Barbosa 807, 918: U guat; 998: U stip - Magnago 347: B matt - Maguire et al. 23793: U guat; 24124: U glau; 27394 A: U guat; 28157, 40505, 40526: U glau; 56665: O amaz; 60170: U spec - Maia 197, 284: U guat - Malme 1442 B, 1741, 2195a, 2195b, 2195c: U guat; 2390: B matt - Marcano-Berti 258, 306, 506, 584: U glau - Marimon 94: U guat - Marin, E. 148: B mult; 216: U spec; 255: B cane; 623: B mult; 1017: O amaz; 1207, 1220: B mult; 1255: B cane; 1708: B mult; 1753: U spec; 1929: B mult - Marín, J. et al. 229: U osae; 528: U theo - Marshall et al. 145: U rufe; 387: U pitt - Martinelli 14447: U guat - Martínez M.P.G. et al. 1827: U sp. - Martins \& Pereira 41: B plei - Martius s.n.: U vene - Marulanda 2065: U colo - Mathias \& Taylor 3930, 3966, 5449: U guat - Matthews 1421: U guat - Maxon 6890: U pana - McDaniel, F. \& Santiago 2490: U guat - McDaniel, S.H. et al. 16295, 16308, 17910, 19925, 20171, 20488, 20754: U guat; 20766, 27453: U stip - McDowell et al. 3375: U guat; 4350: U glau - McPherson et al. 7590: U stor; 7665: U megs; 7971: U pana; 8001: U aff. long; 10040: U pana; 10150: U bull; 10153: U aff. long; 10604, 10747: U pitt; 10748: U bull; 10765 , 10789: U stor; 11859, 12380, 12393: U pitt; 12463: U bull; 12539, 12729, 12729A: U stor; 15398: U dari - Meier 3391, 4334: U cosn - Mélinon 19: U rufe; 121, 426: U perr - Mello et al. INPA 2271: U stip; INPA 3487: B mult; INPA 4017, INPA 4236: U stip - Menacho \& Driement 673: U guat - Mendes 3428: U guat - Mendonça et al. 3939: U guat - Meneces et al. 205: U flor; 2210: U guat - Mereles 618: U guat - Mexia 6030: U guat - Meyer 114, 126, 127, 128: U guat - Michel et al. 2222: B mult - Milliken et al. 634: B mult - Miller et al. 754: U duck - Miralha, J.M.S. et al. 131: U guat; 162, 206: B mult; 267, 269, 281: U duck; 300: B plei; 309: U guat - Molino et al. 1597: U stip; 1598: U rufe; 2000: U perr - Monsalve B. 652, 1755, 1989: U colo - Mora Castro 369: U cost - Mora O. et al. APA 234: U vene; 823: U hamm - Moraes R. 804, 927: U guat - Morales et al. 347: U theo; 5776: U cf. pitt; 5860: U theo - Morawetz et al. 375: U vene; 11-8983: O amaz; 32-7983: B cane - Moreno 23348: U pitt - Moretti 1130: U stip - Mori et al. 1975: U pana; 2241, 2838, 2863: U stor; 3326, 3519: U pana; 5548: U pitt; 8207: U glau; 8404, 8563: U rufe; 8622: B mult; 8777: U rufe; 9082: U stip; 9319, 9727, 9766, 9833, 11936, 13937: U bahi; 14672: U cosn; 14831, 15069, 15427: U rufe; 15507: U stip; 15536: U perr; 15645, 16071, 16331: U stip; 17555: U perr; 17976: U stip; 18035: U rufe; 18962, 20141, 20988: U stip; 21512, 21619: U rufe; 21664: U perr; 24369: U guat; 24829: U perr; 25138: U rufe; 25558: U stip - Morillo 3434, 6994: U stip - Mostacedo et al. 59: U guat - Munhoz 62: B matt - Murillo et al. 503: U guat; 527, 528, 567: U flor; 589: U stip; 591: U vene; 629: U eleg; 632: U stip; 637: U eleg — Murray \& Johnson 1495: U bull; 1529: U guat; 1552: U vene; 1556: U spec; 1563: U stip; 1570: U guat - Mutchnick et al. 151: U rufe; 461: U guat; 785, 1055: B mult; 1094: U guat; 1488: U perr.

Nascimento 738: U stip - Nee et al. 7738, 9596, 9662: U pana; 9679: U pitt; 11371: U pana; 30827: U stip; 34771, 34918: B mult; 38704, 38728, 38817, 40118: U guat; 42398: U rufe; 42471: U stip; 42508: B mult; 42660: U guat — Neill et al. 2608: U pitt; 6774, 6785: U vene; 8759: U flor; 8865, 9034: U vene; 9053, 9437: U flor; 10300: U vene; 11379: U magn; 13660: U flor - Nelson, B.W. 1605: U guat; 2106, 2353: U stip - Nelson, W.N. et al. 408: B mult - Nunes RB 83981: U ried - Núñez et al. 1917: U guat; 5369: U flor; 6194: U guat; 10507A, 10567, 10622: U flor; 10709, 10720, 10750, 10778: U guat; 10783: U flor; 10838, 10925: U guat; 11003: U flor; 11127, 11166, 11808, 11824, 11829, 15097, 15349: U guat — Nutz 290: U guat.

Obando 119: U cost - Oldeman et al. T 45, 237: U guat; 292: U stip; T 297: U guat; T373, B474: U stip; T725, T879: U guat; T888: U stip; 1218, B1229, B1363, B1404, 1612, 1757, 1784, B 1889, B2020: U guat; 2059: U rufe; 2934: U guat; 3235: U stip; B3237, B3510: U guat; B4032, B4168: U stip - Oldenburger et al. 1109: B mult; 1205: U stip; 1281: B mult - Oliveira, A.A. et al. 162: B mult; 170: U duck; 206: O peri; 209, 297: O amaz; 365, 587: B mult; 1157: O amaz - Oliveira, E. 1716: U guat; 4110, 4260, 4602, 4736: U stip - Oliveira, P.I. \& Anderson 397: U guat - Oliveira, P.P. 232: U ried - Øllgaard et al. 39177, 57089, 57107: U vene - Orava 9: U rufe - Ortega U. 147: U flor - Ortiz, R. et al. 58: U stip - Ortiz S., S. 197: U guat.

Palacios, P.A. et al. 1777: B cane - Palacios, W. et al. 495: U flor; 660, 1106, 1228, 1670: U vene; 1942: U sp.; 2010: U vene; 2185, 2206, 2313: U flor; 3007, 3067: U vene; 3483, 4638: U flor; 
5214: U magn; 7891: U vene; 8039, 8051, 8154: U flor; 8588: U spec; 9431: U flor; 11346: U esme; 12039: U vene - Panfil 1228: B matt - Pardo et al. 115: U flor - Paredes et al. 727: U bull; 737: U stor - Pedersen 11092: U guat - Peixoto et al. 710: U guat; 3503: U sanc - Peña 71, 570: U guat; 697: O peri - Pennington, R.T. et al. 11: O peri; 323: U guat; 401: U stip - Pennington, T.D. et al. 378: B mult; 10632, 10641: U flor; 10668: U magn; 17236: U eleg; P22769: B mult - Peralta 625: U bull - Pérez et al. 858: U pitt - Perrottet 64, 65, 67: U perr - Perry et al. 468, 588: U guat; 714: O peri - Persaud 165 (=FDBG 6922): U perr - Pessoal do C.P.F. INPA 6085: B mult - Pessoal do L.P.F. 1318: O amaz - Peters 42: U flor - Philipson et al. 2209: U silv - Phillips et al. 408, 417: U guat - Pipoly et al. 6779: B cane; 8627, 8944: U rufe; 12256: U vene; 12553: U spec; 12608: U vene; 12683: U stip; 12745: U guat; 13597: U stip; 13930, 14502, 14511: U vene; 14653, 15017: U stip; 15361: U vene; 15642: U guat; 15683: U vene; 15751: U spec; 16003, 16041, 16444: U vene; 18323, 18363: U long - Pirani et al. 1345: B matt; 2081: U guat; 2942, 2987, 3010: U bahi — Pires et al. 3614: B mult; 3631: O amaz; 3776: U guat; 3978: B mult; 4692, 7013, 7073, 11024: U guat; 14793, 16893: B mult; 50371, 50385, 50428, 50607: U guat; 50608, 50642, 50960: U stip; 51349, 51587, 51855, 52116: U guat; 52214: U stip; 52587: U guat - Pirie et al. 18, 46, 55: U flor; 63: U sp.; 65, 75: U aste; 76: U peru; 79, 85: U spec; 87, 106: U peru; 108: U aste; 113: U spec; 117, 118: U aste; 121: U spec; 149: U peru; 161: U guat - Pittier et al. 3871: U pitt; 15423: U cosn - Plowman et al. 5810: U guat; 7186: U vene; 8467: U guat; 12422: B mult - Poeppig 3: U guat; 2668: B mult - Polak et al. 47, 63, 179: U glau; 201: U stip; 388: U rufe; 525: U glau; 591: U guat - Poncy et al. 1798: U stip - Poulsen 78043, 78286: U magn - Poveda 995: U pitt - Prance et al. 1317: U guat; 1387: U stip; 1627: U guat; 2170, 2171: U duck; 2394: U guat; 2496: B mult; 2667, 2800: U guat; 3708: B mult; 3791: B plei; 5049, 5062: B cane; 5255, 5618: U guat; 5791: O peri; 5827, 5929: B cane; 6057, 6632: U guat; 6806: O peri; 7343: U vene; 7574: U guat; 7912: O peri; 8140: U stip; 8250: U stip; 8514: U guat; 8628: B cane; 8730: U guat; 8792: B cane; 10536, 10571, 10812, 10853 : B mult; 12185: U guat; 12298: U stip; 12390: U flor; 14213: U guat; 14323, 14418: U stip; 14449: U guat; 15694: U vene; 16308, 16369, 16407: U guat; 16852: U vene; 17823, 18754: U stip; 19249: B matt; 20511: B mult; 20622: U guat; 22714, 22894: B mult; 22981: U duck; 23168: B mult; 23759: U eleg; 23876, 24122: U stip; P25438 , P25446 , 26241, 26289, 58562, 59526: U guat - Prévost et al. 200, 279, 353, 836, 1110: U stip; 1305: U guat; 1442, 2007: U stip; 2627: U rufe; 3565: U stip; 4468: U perr - Pulle 328: U glau.

Quevedo et al. 2410, 2434: O peri; 2718: U guat.

Rabelo et al. 2877: U stip; 2892: U rufe - Raes \& Iraipi 216: U guat - Rainer 171: U theo; 236: U guat - Ramírez, J.G. \& Cárdenas L. 336, 425: U avic; 485: U sess; 573: U avic; 612: U sess; 730: U avic; 773: U sess; 1277: U avic; 1540: U sess; 1544, 1623: U avic - Ramírez, J.O. \& Paredes, J. 2403-2: B mult - Ramírez C., R. 64: U peru; 133: U spec; 141: U stip - Ramos 832, 1181: O amaz - Ratter et al. 2171, 2191, 2216, 3542, 3558, 4433, 5035, 5233, 7092, 7181 : U guat; 7367, 7372, 7474V: B matt - Regnell III-248: U guat - Reitz \& Klein 12116: U guat - Rentería A. et al. 1509, 2098, 2181, 2698, 2736: U avic; 3000: U sess; 10810: U paci - Restrepo \& Matapi 490, 515, 517: U guat; 576: U flor; 587: U eleg; 601, 607: U guat - Revelo 87, 130: U flor; 249: U vene - Revilla et al. 637: U vene; 898: U guat; 950: U vene; 1842, 1869: U guat; 2342: U eleg; 2682: U spec; 3558, 3663, 4304: U stip; 4535: U guat - Reynel R. 970: U vene - Ribeiro, B.G.S. et al. 1194, 1588: U guat - Ribeiro, J.E.L.S. et al. 809: U stip; 1045: B plei - Riedel s.n. (October 1823): U ried; 722, 1247: U guat; 1460: B mult - Riera 261, 675: U stip - Rimachi Y. 189: U stip; 1058, 1838, 1887, 1908, 1940, 1966, 2224, 2328, 2592: U guat; 2605: B cane; 2937: U flor; 3094: U stip; 3188: B cane; 3435: U flor; 6724: U guat; 6910: U peru; 7194: U stip; 7219, 7578: U vene; 7597: U stip; 9552: U flor; 9865: B cane; 10281: U guat - Ríos et al. 460: U flor; 556: U stip; 720: U guat - Rivera \& Herrera 2288: U pitt - Rivero 131: U flor - Robles et al. 1868, 2009: U pitt - Rodrigues et al. 331: B cane; 392: B mult; 745, 942: U guat; 1002, 1296, 1345: U stip; INPA 1613: U guat; 1885: U duck; 2275, 3075: U stip; 4386: U guat; 4437: O amaz; INPA 4441: B cane; 5725, 5766: B mult; 5939: U guat; 6011: B plei; 6768: U duck; 7225: O amaz; 7523: O plei; 8675: O amaz; 10498: B cane - Rodríguez, A. et al. 636: U bull; 1751: U pitt; 2269, 4536: U stor; 4841, 5200: U pitt - Rodríguez, H.A. et al. 2550: U guat; 10134: U glau — Rodríguez R., E. \& Reyes M. 1789: U mont - Rojas et al. 89, 155: U peru; 670: 
U guat - Roldán et al. 1954: U paci - Rombouts 2713: U guat - Romero et al. 1864: U stip - Romero-Castañeda 3802: U vene; 4074: U stip; 4781: U avic - Romoleroux et al. 1802, 1846, 2306: U vene - Rosa et al. 222, 1010: U guat; 1798: U stip; 2040, 4389: U guat - Rosário \& Silva, M.F.F. 665: O amaz - Rosas Jr. et al. 265: U flor; 327: U stip; 332: U spec - Rubio et al. 114: U vene; 217, 798: U flor - Rudas et al. 1282, 1341: U vene; 2219: U guat; 3029, 3134: U vene; 3260: U spec; 3403: U flor; 4178: U sp.; 4312, 5599: B cane - Ruiz s.n. (1800): U magn - Ruiz, J.C. et al. 646: U stip; 820,1307: B cane; 1423, 1425: U stip; 1554, 1555: U vene - Ruiz M., J. et al. 5248, 6377, 6547, 7248, 7540, 7554: U guat - Ruokolainen et al. 414, 489, 1052, 1166, 2938: B cane - Rusby 1253: U guat.

Sabatier et al. 2656, 2777: U perr; 2807, 3145: U rufe; 3308: U glau; 3529: U rufe; 3530: U stip; 3585, 3924: U rufe; 4236: U sp.; 4272, 4611: U stip — Saddi \& Mattos Filho 3433: U guat - Sagástegui A. 6863: U guat - Saldías \& Lawrence 1461: U guat - Sánchez S. et al. 320, 354: U long; 572: U paci; 1079: U avic - Sandwith 355, 1188: U glau - Sanoja et al. 2576: B mult; 3169, 3195 : U stip; 3244a, 3262: B mult; 3355: U stip - Sant'Ana et al. 983: U bahi - Santos, F. S. et al. 341, 489, 569: U bahi - Santos, G. et al. 478: O amaz; 641: B matt - Santos, H.G.P. et al. 465: U guat - Santos, J.P. et al. 45: O peri - Santos, M.R. 308: U stip; 407: U guat - Santos, R.R. de et al. 1247: B matt; 1660: U guat - Santos, T.S. 582, 1929: U bahi - Saraiva et al. 183: U guat - Sastre et al. 638: U flor; 4108: U guat; 4416: U stip; 5929, 8212: U guat - Scharf 6: U rufe - Schatz et al. 683, 684, 685: U pend; 747: U guat; 994: U pitt; 1213: U theo - Schipp 400, 1203: U pitt - Schnell 12240: U guat - Schultes et al. 3893: U stip; 6688, 8541: U vene; 8947, 9549, 10064: U stip; 12412: U vene; 12425: U stip; 12730, 12770, 13670: U vene; 13782, 13795, 13797: U guat; 15201, 15269: U vene; 16005: U eleg; 16034: B mult; 16113: U vene; 16199: U eleg; 16959: U guat; 17323: U stip; 17639, 17645: U guat; 19327: U vene; 19607: U eleg; 20078, 24103, 24303: U guat - Schulz LBB 7718, LBB 7968: U rufe; LBB 8006: U guat; LBB 8154: B mult; LBB 8160: U rufe; LBB 8318, LBB 8634: B mult; LBB 9314: U rufe - Schunke V. 1611, 1641: U guat; 2154: U spec; 2547: U guat; 2779: U spec; 4058: U guat; 4999: U flor; 5973: U guat; 6030: U guat; 6283: U flor; 7056: U guat; 7768: U flor; 9599: U guat; 12478: U flor; 14116: U guat; 14782, 15198: U flor; 15293: U guat; 15512: U sp. - SEF (Studies of Ecuadorean Forests) 10084: U flor - Segura \& Quesada 70: U pitt - Seidel et al. 2401, 3602, 6036, 6575: U guat - Serato 162: U flor - Shattuck 654: U pitt - Shepherd 802: U megp - Silva, A.S.L. et al. 200, 1444: U guat; P25170: O amaz; P25360: B mult; P25794: U rufe; P25798: B mult - Silva, D. G. et al. 9: U flor - Silva, G.P. et al. 3574, 6597, 8991: U guat - Silva, I.A. 344: U rena - Silva, J.A. et al. 674: B mult - Silva, L.A.M. et al. 615, 978, 1041, 1215, 1269, 1392, 1940: U bahi - Silva, M. et al. 374: U stip; 1196, 1277, 1337: U guat; 2513, 2565, 2638: U stip - Silva, M.F. et al. 1549: U guat - Silva, M. G. et al. 555, 701, 2395, 2496: B mult; 3530: B matt; 3849: B mult; 3927: B plei; 3948: U rufe; 4507: U guat; 5538: B matt; 5614: U guat; 6277: B mult - Silva, M.N. et al. 291: U guat - Silva, N.T. et al. 934, 1504: B mult; 1775: U stip; 1945: U guat; 1975: U stip; 2348: U guat; 4608: U duck - Silva, S. S. et al. 50: U guat - Silveira et al. 762: U guat; 874: O peri; 1460, 1462: U guat - Silverstone-Sopkin \& Quintero 459: U guat - Simpson et al. 646, 737: U vene; 770: U stip - Smith, A.C. 2594: U guat - Smith, D. 424: U pitt - Smith, D.N. et al. 13263, 14117, 14157, 14176, 14236: U flor - Smith, H.H. \& G.W. Smith 1359, 1539: U guat - Smith, S.F. et al. 168: O peri; 1414: U guat; 1569: U flor - Sobel et al. 4877: U guat - Sobrevila et al. 1844: U flor - Soejarto et al. 578: U stip; 792: U vene; 2387: U eleg; 3488: U ? macr; 3605: U seri; 3668: B mult; 4007: U paci - Solomon et al. 3602: U stip; 6368: B mult; 7902, 12420, 14744, 17151: U guat - Soria S. 22: U flor - Sothers et al. 145: B plei; 464: U stip; 513, 744: B plei; 804: B mult; 893: U stip - Souza, J.A. 100: B plei; 198: U duck; INPA 61802: U stip - Souza, M.A.D. et al. 266: U guat - Souza, S.A.M. et al. 1044, 1204: U guat - Sperling et al. 5925: O amaz - Spichiger et al. 1022: U stip; 1755: U flor; 1756: U spec; 1758: U stip; 4077: U flor; 4087: U spec; 4088, 4089: U flor; 4766: U stip; 4767, 4768: U flor; 4769: U stip - Splitgerber 921: U guat - Spruce 1301: B mult; 1572: U stip; 2567, 2576, 2745, 3163: U guat; 3549: B cane; 4402: U guat - Stahel 225: U rufe; 370: U guat - Standley 33897: U cost - Stein et al. 3993: U vene - Stergios et al. 8989, 9002, 9612: U guat - Stevens et al. 23647, 24245, 24282, 24514: U stev; 24595: U pitt; 24716, 24832: U stev; 24861, 24904: U pitt - Stevenson, D.W. et al. 1015: U stip - Stevenson, P. 2083: U flor - Steward et al. P20108: 
B mult; P20268: U rufe - Steyermark et al. 86408, 86420, 87394, 87691: U glau; 90326: U guat; 95229, 106731, 119759: U cosn; 122216: B mult; 122425, 122450: U spec; 122462: U stip; 123769, 123801: U cosn; 126278: U guat - Stoffers et al. 29, 102: U rufe - Stork 4608: U stor - Sucre 8355: U rena; 10399: U guat - Sugden 443: U stor - Sytsma \& D'Arcy 3326: U dari.

Tate 880: B mult - Taylor \& Skotak 4408: U stor - Tello 33: U flor - Ter Steege et al. 279: U stip; 368: U perr - Tessmann 3262: U flor - Teunissen-Werkhoven LBB 15334: U guat - Thomas, E. et al. 2022, 2170: U guat - Thomas, W.W. et al. 4544: B matt; 4984: O amaz; 5009, 5143: U duck; 5245: U stip; 5269: U sp.; 8980, 9071, 10020, 10110, 10146, 10908: U bahi; 11446: U sp. - Thomaz 789, 792: U sanc - Thomsen et al. 96, 179: U osae; 384, 415, 1122: U pitt; 1353 : U sp.; 1570, 1571: U pitt - Tillett et al. 45638: U perr - Timaná et al. 1415B, 1468, 1555, 1603, 1605, 2035, 2377, 2698, 2941, 3045: U flor; 3139: 3299, 3302, 3314, 3343, 3389: U guat; 3440: U flor; 3455, 3558: U guat - Tipaz \& Quelal 666: U paci - Tirado et al. 284, 348, 726 : U esme - Tiwari et al. 506: U guat; 621: U rufe; 897, 973: U glau - Todzia et al. 2279: U guat — Tonduz 4592: U pitt; 7592: U osae - Traill 7: U guat - Tresling 461: U glau - Tún Ortíz 2445: U pitt - Tutin 61: U glau - Tyson \& Kuns 999, 1000: U guat.

Ule 5795: U spec; 6191: U stip; 6341, 9369: U guat - University of Guyana Course Neotropical Botany 54: B mult; 83: U perr; 85: U glau; 89: U stip - Unknown collector s.n. (1831), 138, RB 4470: U guat; RB 11355: B mult - Urrelo et al. 634: U guat - Utley, J. \& Utley, K. 1183: U osae - UVS et al. 17768: U stip.

Valderrama S. et al. 25: U stip - Valearcel 68-3B, 146-5/B, 464-3J, 734-5/G: U flor - Valencia et al. 67455, 67506, 67925, 68282, 68372, 68415, 68477: U magn - Valenzuela et al. 2092, 2170, 3329: U flor; 4242: U guat - Valera 88: B mult - Valverde \& Zúniga 1391: U pitt - Van Andel et al. 70: U guat; 722, 885, 1672, 1917, 2020, 2048, 2341, 2492: U glau; 4571, 4714: U rufe; 4765: U guat - Van der Werff et al. 9927: U vene; 19504: U mont - Van Donselaar 1434: U guat; 1678: U stip; 2958: U rufe; 3513, 3738: U stip; 3782: U glau - Van Rooden et al. 587: U paci - Vargas, H. et al. 790: U flor; 1098: U sp.; 6112: U magn - Vargas, L. et al. 1025: U guat - Vargas, L.D. et al. 128, 347: U theo - Vargas, O. 129, 493: U pend - Vargas, W.G. 6370: U sess - Vargas C., I.G. et al. 1917, 2554, 2586, 2588, 2689, 2815: U guat - Vásquez et al. 1002: U stip; 1015: U flor; 1393: U eleg; 1566: U spec; 1790, 2116: U stip; 2789: U peru; 3765, 4056: U vene; 4230, 4242: U guat; 4534: U vene; 4614: U eleg; 4629: U vene; 4632: U stip; 4933: U vene; 5055: U stip; 5184: U vene; 5356: U stip; 5482, 5495: U guat; 5682: U stip; 5684: U guat; 5689: U stip; 5873: U eleg; 6284, 6375: U flor; 6822: U stip; 6974: U spec; 6975: U guat; 7013: U flor; 7057: U guat; 7120: U eleg; 7259, 7320, 7537, 7560: U vene; 7627: U guat; 7784: U peru; 7831, 7950: U vene; 8063: U eleg; 8154, 8265: U vene; 8301: U flor; 8353, 8545: U vene; 8548: U flor; 8667: U stip; 8851: U guat; 8870: B cane; 8958: U vene; 9010: U guat; 9093: U vene; 9239, 9241: U guat; 9634: U stip; 9912: U flor; 9921: U vene; 9931 A: U flor; 9994, 10142: B cane; 10235: U guat; 10644: U flor; 10774: U vene; 10838, 10868: U stip; 11160: B cane; 11339, 11782: U flor; 11950: U peru; 12099, 12352: U vene; 12354: U stip; 12375, 12538: U vene; 12788: U stip; 13017: U vene; 13884: U peru; 14220, 14305, 14550: B cane; 14793, 15042: U flor; 15230: U stip; 15324: B cane; 15583, 15863, 15904, 15928, 16056: U vene; 16407, 16420: U flor; 16526: U stip; 16551: U peru; 16910: U flor; 17017: U vene; 17049: U flor; 18369: B cane; 19193: U guat; 21146, 21822: U aste; 22383: U guat; 22797: U stip; 23290: U spec; 23553, 24566: U guat; 25848: U flor; 26179, 26185: U mont - Velásquez et al. 169: U avic - Velazco 314: U guat; 371: U spec; 467: U stip; 1017, 1047: B cane - Versteeg 687: U guat - Vester \& Román 7: U stip - Vicentini et al. 612: U duck; 764: B mult; 1205: U duck - Vickers 222: U vene - Vieillescazes 432: U stip; 436: U rufe; 554: U stip - Vieira, M.G. et al. 978: O amaz - Vieira, R.F. et al. 1927: B matt - Villa et al. 269, 285: U flor; 298: U vene; 813: U flor; 1011: U vene - Villiers et al. 1728: U stip; 1984, 2008: U rufe; 2026, 2098: U stip - Vincelli 1117: B mult.

Wachenheim 14, 380: U perr; 398: U rufe; 470, 520: U perr - Wallace et al. 103: O peri - Wallnöfer 14-181188: U sp. - Walter et al. 113, 1034, 1805: U guat - Warner 301: U long - Wendt et al. 5684: U mexi - Werner 31 P: U guat - Wessels Boer 995: U guat - White s.n. (12 March 1922): O peri - Williams, Ll. 650: U stip; 841, 1122, 1184: U peru; 1204: U guat; 1941, 2320, 3408: U vene; 3449, 3645: U guat; 3772: U vene; 4112, 4188, 4608, 5346, 5455, 5462, 5467, 5562, 
6303, 6490: U guat; 10315: U cosn; 14644: U stip; 18203: B mult - Woytkowski 5463, 7181, 7280, 8348, 8354: U guat - Wurdack et al. 40954: B mult; 43585: U stip.

Young 56: $\mathrm{U}$ vene.

Zak et al. 4000, 4494, 4570, 4787, 5055, 5203: U flor - Zamora et al. 1282, 1327, 1455: U theo; 1898, 1979: U pitt - Zarucchi et al. 1424, 1975: U guat; 2070A, 2097A: U vene; 2987, 3159: B mult; 4901: U colo; 5054: U dari; 6688: U paci - Zaruma \& Arguello 498: U vene; 515: U flor - Zent 586-68: U stip; 885-39c: B mult - Zimmermann 20, 190: U guat - Zonta et al. 143: U flor - Zuleta 136: U flor - Zuniga 477: U cost.

\section{LIST OF VERNACULAR NAMES}

Vernacular names were taken for the most part from herbarium labels, and also from reliable literature sources. The most important literature references we consulted are Murillo-A. \& Restrepo (2000) and Van 't Klooster et al. (2003). Abbreviations as in Identification list.

A kusuwe fuuta (U rufe)

A teki uma udu [A teiki uma udou] (U rufe, U stip)

Achuana [Ačuána ] (U aste, U guat)

Aiconatio (U spec)

Akare pomëirjë [Akare pomi'irï] (U guat)

Amose-rang [Amosérian] (U rufe)

Anoncillo (B mult)

Anonilla [Anonillo] (B cane, $\mathrm{U}$ cost, $\mathrm{U}$ guat)

Anono amarillo (U pitt)

Apotai wewe (U rufe)

Aradek (B mult)

Araidya [Araid'a, Araita] (U rufe)

Arara (B mult, U glau, U perr, U rufe)

Arara, rough bark (U stip)

Arara, rough skin (U glau, $U$ guat)

Arara yariyari - see under Yariyari

Arara-yek (B mult)

Aratia (U rufe)

Araticum [Ariticum] (U guat)

Ata do igapó (U guat)

Ata meju (B mult)

Atinha (U guat)

Auca hicoja (U spec)

Awigue (U glau)

Azau-udu [Azo udu] (U glau, U perr, U rufe)

Baeda (U glau)

Bara [Barra] (U guat, U vene)

Bara caspi [Bara-caspi] (U guat, U peru, U stip, U vene)

Bilibëte (U guat)

Black hue yariyari - see under Yariyari

Black yariyari - see under Yariyari

Boszuurzak (B mult, U rufe)

Busisunsaka (U rufe)

Cacahuillo (U spec)

Cacao de montaña (U magn)

Cajao dujecu (U guat)
Caña iguapo, aguas negras (B mult)

Caño iguapo (B cane)

Cara caspi (U flor)

Carahuasca (O peri, U eleg, U flor, U stip)

Cärärä Dau (B mult)

Carbón de montaña (U pitt)

Cargadera negra (U onyc)

Cargadero (U colo, $\mathrm{U}$ magn, $\mathrm{U}$ paci)

Carguero (U flor, U stip)

Chocolatillo (U flor, U guat)

Chocolatillo blanco (U flor)

Choo-ree (U stip)

Choon (U vene)

Cililicuato (U stip)

Čiwánim yais (U guat)

Cocolate-dmbwer (U guat)

Copal (U guat)

Cotibi (O peri)

Cundurú (U guat)

Duguecu (U guat)

Edisha (B mult)

Envira [Invira] (B matt, B mult, U duck, U flor, U guat)

Envira cajú [Inuira cajú] (O amaz, O peri)

Envira cascuda (U duck, U stip)

Envira cheirosa folha grande (U spec)

Envira da várzea (U guat)

Envira do caiso (U guat)

Envira do igapó (U guat)

Envira preta (B mult, B plei, O amaz, U duck, U flor, U guat, U stip)

Envira preta do igapó (U guat)

Envira surucucú [Envira surucucu, Invira surucucu] (B mult, U duck, U guat, U stip)

Envira surucucu da várzea (U guat)

Envireira (B mult, U duck, U flor, U stip)

Envireira casca rocha (O amaz)

Envireira preta (B mult) 
Erisha (B mult)

Espintana (B cane, U eleg, U flor, U guat,

U peru, U spec, U stip, U vene)

Espintana negro (U stip)

Ewokpokan (U guat)

Femelle mama yawé (U stip)

Foonïdujecu (U flor)

Foonïdujecu de hoja pequeña (U guat)

Fructo e' burro montañero A (B mult)

Gaan busi azau-udu (U rufe)

Gabiroba (B mult)

Gagoti (U rufe)

Garrapata (U megp)

Guanabita (U cosn)

Guasca negra (U onyc)

Gururei (U stip)

Hicoja - see under Icoja

Hicoja amarilla (U guat)

Hicoja negra - see under Icoja negra

Hicoya - see under Icoja

Hoja hedionda (U guat)

Hö-rö'-rai (U stip)

Huabu midha (U flor)

Huasi caspi (U flor)

Icïbono-fiiquicï (U stip)

Icoja [Hicoja, Hicoya] (B cane, U flor, U guat,

U peru, U spec, U vene)

Icoja blanca (U flor)

Icoja colorada (U flor)

Icoja negra [Hicoja negra] (U flor, $\mathrm{U}$ guat,

U peru, U spec)

Imbiú branco (U ried)

Imbiú preto (U ried)

Inuira cajú - see under Envira cajú

Invira - see under Envira

Invira surucucu - see under Envira surucucú

Invireiro surucucu (B mult)

Jirïda (U stip)

Jïrirai [Jïrurai, Jirirai] (U stip)

Jurueira sangue (B plei)

Kaiman pepre (U guat)

Karara (B mult)

Karishiri [Karashiri] (U glau, U perr)

Kayayeis (U flor)

Kleinbladige yariyari - see under Yariyari

Koawi (U colo)

Kunjuasta (U spec)

Kuukumwi priye (U stip)

Kwaranapoiballi (U guat)

Laagland kleinbladige yariyari - see under

Yariyari

Laurel (U guat)

Llanta caspimuyu (U flor)

Macagua (U cosn)
Mahot rouge (U stip)

Majagua (B cane, B mult, U stip)

Majagua blanca (U stip)

Majagua candelero (U stip)

Majagua de tierra firme (U stip)

Majagua negra (B mult, U stip)

Majaguillo (U stip)

Majãúe (U guat)

Mama yawé [Maman yawé, Mama yowé] (U guat, $\mathrm{U}$ perr, $\mathrm{U}$ rufe, $\mathrm{U}$ stip)

Maman yawée de l'eau (U guat)

Mamanyaret (U rufe)

Man pikapika (B mult)

Marañon del monte (O peri)

Mati muyo (U flor)

Mee-see-mo-hoó (U stip)

Mejo de porco (U guat)

Mejo de porco de cerrado (B matt)

Meña (U flor)

Midha dhahua (U guat)

Miret (U guat)

Moncapatahue [Mongapatahue] (U flor, U vene)

Mongapata (U flor)

Monte-chirimoya (U guat)

Morteira (B mult)

Mulato (U avic)

Murewa-rang (U guat)

Mutambi (U guat)

Muxiba (U guat)

Mwaba (U rufe)

Nagüí (U flor)

Namakia yais (U guat)

Okaypu (U stip)

Pakirem priye (U stip)

Palo anavelo (U stip)

Palo de anzuelo (U vene)

Palo salao (U guat)

Panta (B mult, U glau, U guat, U rufe)

Parro (U vene)

Pegreku pisi (B mult)

Pepre nanga sowtu [Pepe nanga saotou] (U guat, $\mathrm{U}$ stip)

Pepre sowtu [Pepre zoutoe, Pepre soitu]

(U glau, U rufe, U stip)

Pepre udu [Peperhout] (U glau, U rufe)

Pỉ ha' ti (U vene)

Pikapika (B mult, U glau, U rufe, U stip)

Pilasiay (U stip)

Pina'ï (U guat, U stip)

Pina'ïtay (U rufe, U stip)

Pina'ïtowu (U stip)

Pindaíba (U bahi, U guat, U rena, U stip)

Pindaíba branca (U guat) 
Pindaíba da mussununga (U aura)

Pindaíba preta (U bahi, U guat, U stip)

Pipirri (B mult)

Piraquina [Piriquina] (B mult, $\mathrm{O}$ peri, $\mathrm{U}$ guat)

Piraquina negro (U flor)

Pojolóa (U guat)

Rough bark arara - see under Arara

Rough skin arara - see under Arara

Rumicara caspi (U vene)

Sïfcó (U guat)

Sacha carahuasca (U flor)

Sarïmïc (B cane)

Schisohsiom (O peri)

Tanoajua (U spec)

Tapïseipio (U glau)

Telahl det (U onyc)

Tortuga (U flor)

Tortuga caspi (U flor, U stip)

Uchi yais (U guat)

Vara [Barra] de pescar (U stip)

Waï (U rufe)

Wáshi yéis (U aste)

Watertamarinde (U guat)

Watrapanta (U guat)

Weé-goo-moo (U guat)

Xahuisi (O peri, U guat)

Yais (U guat, $\mathrm{U}$ peru)
Yana cara caspi (U vene)

Yara Yara (B mult)

Yara Yara amarilla (U glau)

Yara Yara negra (U glau)

Yara Yara negra grande (U glau)

Yariyari [Yari yari] (B mult, U glau, U guat, $\mathrm{U}$ rufe, $\mathrm{U}$ stip)

Yariyari, arara (U glau)

Yariyari, black (B mult, U glau)

Yariyari, black hue (U glau)

Yariyari, kleinbladige (B mult, U rufe)

Yariyari, laagland kleinbladige (U guat)

Yariyari, yesi (U perr)

Yaú (U stip)

Yáw-töt (U guat)

Yaya (U paci)

Yaya blanca (U pitt)

Yayis (U flor)

Ycoje (U guat)

Yeitz (U spec)

Yeseredan (U rufe)

Yeseredan hohorodikoro (U rufe)

Yeseredan unirefodikoro (U guat)

Yesi yari yari - see under Yariyari

Yisiko (U stip)

Zuurzak (U rufe)

Zwarte pegreku (B mult)

\section{INDEX TO SCIENTIFIC NAMES}

Accepted taxa are in roman type, new taxa in bold and synonyms in italics. ik = insufficient known and excl. $=$ excluded species. Numbers refer to the genera and species as used in this revision.

Annona peduncularis Steud. 3-17 perrottetii A.DC. 3-32

Bocagea canescens Spruce ex Benth. 1-1 mattogrossensis R.E. Fr. 1-2 multiflora Mart.1-3

Bocageopsis R.E. Fr. [p. 425] canescens (Benth.) R.E. Fr. 1-1 mattogrossensis (R.E. Fr.) R.E. Fr. 1-2 multiflora (Mart.) R.E. Fr. 1-3

var. angustifolia R.E. Fr. 1-3 pleiosperma Maas 1-4

Cremastosperma polyphlebum (Diels)

R.E. Fr. excl.

Desmopsis trunciflora (Schltdl. \& Cham.) G.E. Schatz excl.

Guatteria multiflora Poepp. ex Baill. 1-3 umbilicata Dunal ik veneficiorum Mart. 3-47

Onychopetalum R.E. Fr. [p. 435] amazonicum R.E. Fr. 2-1 krukoffii R.E. Fr. 2-2
(Onychopetalum) lanceolatum R.E. Fr. 2-1

lucidum R.E. Fr. 2-2

periquino (Rusby) D.M. Johnson \&

N.A. Murray $2-2$

Pseudoxandra leiophylla (Diels) R.E. Fr. excl. polyphleba (Diels) R.E. Fr. excl.

Trigynaea angustifolia Benth. 3-17 antillana Rolfe 3-17

boliviensis Britton 3-17

canescens Benth.1-1

galeottiana Baill. excl.

grandis Benth. 3-17

matthewsii Benth. 3-17

periquino Rusby $2-2$

perrottetii (A.DC.) Baill 3-32

var. lanceolata Baill. 3-32

rufescens Baill. 3-37

Unonopsis R.E. Fr. [p. 440]

andersonii Sprague ex Hohenkerk 3-16

angustifolia (Benth.) R.E. Fr. 3-17 
(Unonopsis)

antillana (Rolfe) R.E. Fr. 3-17

asterantha Maas \& Westra 3-1

aurantiaca Maas \& Westra 3-2

aviceps Maas 3-3

bahiensis Maas \& Orava 3-4

bauxitae Maas, Westra \& Mello-Silva 3-5

boliviensis (Britton) R.E. Fr. 3-17

buchtienii R.E. Fr. 3-17

bullata Maas \& G.E. Schatz 3-6

cauliflora Maas \& Westra 3-7

colombiana Maas \& Westra 3-8

costanensis Maas \& Westra 3-9

costaricensis R.E. Fr. 3-10

darienensis Maas \& Westra 3-11

duckei R.E. Fr. 3-12

elegantissima R.E. Fr. 3-13

esmeraldae Maas \& Westra 3-14

floribunda Diels 3-15

galeottiana (Baill.) R.E. Fr. excl.

glaucopetala R.E. Fr. 3-16

gracilis R.E. Fr. 3-17

grandis (Benth.) R.E. Fr. 3-17

guaraya Herzog 3-17

guatterioides (A.DC.) R.E. Fr. 3-17

forma elongata R.E. Fr. 3-17

hammelii G.E. Schatz \& Maas 3-18

heterotricha Maas \& Westra 3-19

leiophylla Diels excl.

lindmanii R.E. Fr. 3-17

longipes Maas \& Westra 3-20

macrocarpa Maas \& Setten 3-21

magnifolia R.E. Fr. 3-22

matthewsii (Benth.) R.E. Fr. 3-17

megalophylla Maas \& Westra 3-23

megalosperma Maas \& Westra 3-24

mexicana Maas \& Westra 3-25

monticola Maas \& Westra 3-26
(Unonopsis)

oblanceolata R.E. Fr. 3-44

obovata R.E. Fr. 3-17

onychopetaloides Maas \& Westra 3-27

osae Maas \& Westra 3-28

pacifica R.E. Fr. 3-29

panamensis R.E. Fr. 3-30

penduliflora G.E. Schatz \& Maas 3-31

perrottetii (A.DC.) R.E. Fr. 3-32

var. lanceolata (Baill.) R.E. Fr. 3-32

peruviana R.E. Fr. 3-33

pittieri Saff. ex Standl. 3-34

polyphleba Diels excl.

renati Maas \& Westra 3-35

riedeliana R.E. Fr. 3-36

rigida R.E. Fr. 3-44

rufescens (Baill.) R.E. Fr. 3-37

sanctae-teresae Maas \& Westra 3-38

schippii R.E. Fr. 3-34

sericea Maas \& Westra 3-39

sessilicarpa Maas \& Westra 3-40

silvatica R.E. Fr. 3-41

spectabilis Diels 3-42

stevensii G.E. Schatz 3-43

stipitata Diels 3-44

storkii Standl. \& L. O. Williams 3-45

theobromifolia N. Zamora \& Poveda 3-46

trunciflora (Schltdl. \& Cham.) R.E. Fr. excl.

umbilicata (Dunal) R.E. Fr. ik

subsp. macrocarpa R.E. Fr. 3-9

velutina Maas 3-42

veneficiorum (Mart.) R.E. Fr. 3-47

williamsii R.E. Fr. 3-17

spec. A ik

Uvaria guatterioides A.DC. 3-17

magnifolia Ruiz \& Pav. 3-22

magnifolia Ruiz \& Pav. ex R.E. Fr. 3-22

Xylopia trunciflora Schltdl. \& Cham. excl. 